\title{
Revision of Lithostrotionella (Coelenterata, Rugosa) from the Carboniferous and Permian
}

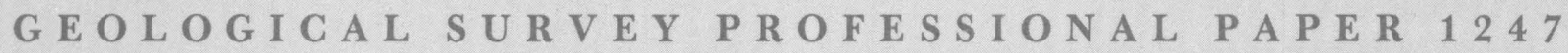

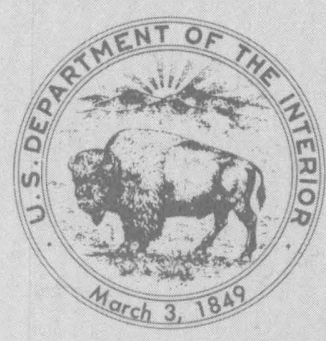




\section{Revision of Lithostrotionella (Coelenterata, Rugosa) from the Carboniferous and Permian}

By WILLIAM J. SANDO

G E O L O G C A L S U R V E Y P R O FE S I O N A L P A P E R 1247

$A$ revision of colonial rugose corals based on restudy of Hayasaka's North American species and the literature on other species

referred to Lithostrotionella

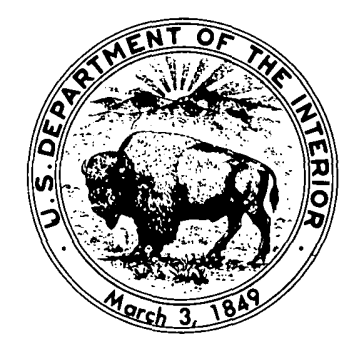


UNITED STATES DEPARTMENT OF THE INTERIOR

JAMES G. WATT, Secretary

GEOLOGICAL SURVEY

Dallas L. Peck, Director

\section{Library of Congress Cataloging in Publication Data}

Sando, William Jasper.

Revision of Lithostrotionella (Coelenterata, Rugosa) from the Carboniferous and Permian.

(Geological survey professional paper ; 1247)

"A revision of colonial rugose corals based on restudy of Hayasaka's North American species and the literature on other species referred to Lithostrotionella."

Includes bibliographical references and index.

Supt. of Docs. no.: I 19.16:

1. Lithostrotionidae. 2. Paleontology-Carboniferous. 3. Paleontology-Permian. I. Title. II. Series. QE778.S24 563'.6 $\quad 81-607828$

AACR2

For sale by the Distribution Branch, U.S. Geological Survey, 604 South Pickett Street, Alexandria, VA 22304 


\section{CONTENTS}

Abstract

Introduction

Acknowledgments

The status of Lithostrotionella

Classification

Phylogeny

Systematic paleontology

Family Lithostrotionidae d'Orbigny, 1851

Genus Stelechophyllum Tolmachev, 1933

Genus Aulostylus Sando, 1976

Family Acrocyathidae new family

Genus Acrocyathus d'Orbigny, 1849

Family Petalaxidae Fomichev, 1953 Genus Petalaxis Milne-Edwards and Haime, 1852

\begin{tabular}{r|} 
Page \\
1 \\
1 \\
2 \\
2 \\
4 \\
6 \\
8 \\
9 \\
9 \\
15 \\
15 \\
15 \\
23 \\
23
\end{tabular}

Systematic paleontology - Continued

Family Lonsdaleiidae Chapman, 1893 Genus Thysanophyllum Nicholson and Thomson, 1876 Genus Lonsdaleia McCoy, 1849 Subgenus Actinocyathus d'Orbigny, 1849

Family Durhaminidae Minato and Kato, 1965 Genus Kleopatrina McCutcheon and Wilson, 1963 _-_- $\quad 37$

Subgenus Kleopatrina McCutcheon and Wilson, 1963

Undetermined lithostrotionelloid corals

Additional taxa _-_-_-_-_-_- 39

Register of USGS localities for Hayasaka (1936) type specimens of Lithostrotionella species

Locality data for USNM specimens not Hayasaka types

References cited _-_-_-_-_-_-_-_-_-_- 42

Index
Page

\section{ILLUSTRATIONS}

[Plates follow index]

Plate 1,2. Stelechophyllum microstylum (White).

3. Stelechophyllum banffense (Warren)?.

4. Stelechophyllum banffense (Warren)? and Stelechophyllum sp. indet.

5. Acrocyathus floriformis floriformis d'Orbigny.

6. Acrocyathus floriformis floriformis d'Orbigny?.

7. Acrocyathus floriformis floriformis d'Orbigny? and Acrocyathus floriformis floriformis d'Orbigny.

8-11. Acrocyathus floriformis floriformis d'Orbigny.

12. Acrocyathus floriformis hemisphaericus (Hayasaka).

13. Acrocyathus floriformis hemisphaericus (Hayasaka) and Acrocyathus floriformis hemisphaericus (Hayasaka)?.

14. Acrocyathus floriformis hemisphaericus (Hayasaka).

15. Acrocyathus proliferus (Hall).

16. Acrocyathus proliferus (Hall) and Acrocyathus floriformis floriformis d'Orbigny.

17. Acrocyathus pilatus n. sp. and Acrocyathus girtyi (Hayasaka).

18. Petalaxis simplex (Hayasaka) and Petalaxis wyomingensis n. sp.

19. Petalaxis exiguus n. sp. and Petalaxis tabulatus (Hayasaka).

20. Petalaxis occidentalis (Merriam) and Lonsdaleia (Actinocyathus) berthiaumi (Merriam).

FIGURE 1. Morphology of the type species of the principal lithostrotionelloid genera

3. Variation in maximum number of major septa and maximum corallite diameter in 56 coralla of Acrocyathus floriformis

\section{TABLE}





\title{
REVISION OF LITHOSTROTIONELLA (COELENTERATA, RUGOSA) FROM THE CARBONIFEROUS AND PERMIAN
}

\author{
By William J. SANDO
}

\begin{abstract}
Species of predominantly massive colonial rugose corals from the Carboniferous and Permian that were referred previously to Lithostrotionella Yabe and Hayasaka are reassigned to the following genera: Acrocyathus d'Orbigny (including probable junior synonym Lithostrotionella Yabe and Hayasaka), Stelechophyllum Tolmachev (including junior synonym Eolithostrotionella Zhizhina), Petalaxis Milne-Edwards and Haime (including junior synonyms Hillia de Groot and Eastonoides Wilson and Langenheim), Aulostylus Sando, Kleopatrina McCutcheon and Wilson, Lonsdaleia McCoy (subgenus Actinocyathus d'Orbigny), and Thysanophyllum Nicholson and Thomson. One of the species referred to Cystolonsdaleia Fomichev is reassigned to Petalaxis.

Stelechophyllum and Aulostylus are referred to the Family Lithostrotionidae d'Orbigny. A new family, the Acrocyathidae, is created for the genus Acrocyathus. Petalaxis is placed in the Family Petalaxidae Fomichev, Thysanophyllum and Lonsdaleia are referred to the Family Lonsdaleiidae Chapman, and Kleopatrina is assigned to the Family Durhaminidae Minato and Kato.

The principal lithostrotionelloid genera are Stelechophyllum, Aulostylus, Acrocyathus, and Petalaxis. Stelechophyllum ranges in age from Late Devonian(?) into the late Viséan and is represented in the Carboniferous by 15 nominal species allocated to five species groups; the genus occurs in the U.S.S.R., U.S.A., Canada, and Mexico. Aulostylus is represented by two middle Tournaisian species in the U.S.A. and Canada and a possible species from the Viséan of China. Acrocyothus is represented by 14 nominal species (one new) from the lower to upper Viséan of the U.S.S.R., U.S.A., Canada, and China. Petalaxis is represented by 41 nominal species (six new) allocated to five species groups that range from the upper Viséan into the Permian; the genus occurs in the U.S.S.R., U.S.A., Canada, Spain, Japan, and possibly China and Spitzbergen.

Stelechophyllum may have been derived from Endophyllum in the Devonian. Aulostylus, Acrocyathus, and Petalaxis are regarded as offshoots from the Stelechophyllum stock in the Carboniferous. Lonsdaleia, Thysanophyllum, and Kleopatrina do not seem to be closely related to Stelechophyllum and its derivatives.

Hayasaka's type specimens of Lithostrotionella species from North America are reassigned to Acrocyathus, Stelechophyllum, Petalaxis, and $A$ ulostylus and are revised specifically. Three new species and two new subspecies are based on specimens studied by Hayasaka.
\end{abstract}

\section{INTRODUCTION}

Inadequate description of taxa is one of the principal deterrents to progress in paleontology. The study of fossil corals has been particularly plagued by this problem because many taxa were proposed before thin- section techniques became widely used and thus were founded largely or entirely on external skeletal features. Until these extant taxa are redescribed and adequately understood, new taxa cannot be proposed without risk of duplication.

In North America, massive colonial rugose corals originally referred to Lithostrotion Fleming and later to Lithostrotionella Yabe and Hayasaka are noteworthy examples of inadequate description. After the genus Lithostrotionella was founded by Yabe and Hayasaka $(1915,1920)$ on material from the Carboniferous of China, Hayasaka studied North American corals in the large U.S. Geological Survey collection of fossils (now housed in the U.S. National Museum of Natural History in Washington, D.C.). Although Hayasaka's visit to the United States was in 1927, his monograph on North American Lithostrotionella was not published until 1936. Hayasaka prepared thin sections from all the holotypes of his North American species, but the thin sections were small and only a few paratypes were sectioned. Consequently, Hayasaka's species concepts were based largely on the holotypes, and many paratypes were incorrectly identified. Moreover, the geologic ages of these specimens were poorly known at the time the study was made. Subsequently, the name Lithostrotionella came into wide use for Carboniferous and Permian colonial Rugosa throughout the world.

I became acquainted with the problem of Hayasaka's type specimens some years ago during the course of investigations of North American Mississippian coral faunas. Easton's (1973) study of Acrocyathus and his conclusion that Lithostrotionella is a junior synonym lent impetus to a restudy of the Hayasaka material. All Hayasaka's type specimens were sectioned and restudied in detail except for four paratypes that could not be found; most of Hayasaka's specimens are illustrated in this report. Other described and undescribed specimens of Carboniferous and Permian age in the collections of the U.S. National Museum of Natural History were also investigated in order to broaden the base for taxonomic conclusions. All locality data were rechecked 
and were revised as necessary on the basis of the latest available information (see locality register on p. 40).

As work proceeded on the Hayasaka material, it became apparent that the classification of this material had broader implications concerning the validity of Lithostrotionella as a taxonomic concept and concerning the scope and phylogeny of other genera. Accordingly, the present study was expanded to include an evaluation of all corals that have been described under the name of Lithostrotionella; this evaluation was based on a study of the systematic literature on these corals as of the end of 1978. I found that most of the specimens originally referred to Lithostrotionella by Hayasaka (1936) should be reassigned to Stelechophyllum, Aulostylus, Acrocyathus, and Petalaxis (table 1). Corals assigned by other authors to Lithostrotionella also belong in these genera, but a few are assigned to Thysanophyllum, Kleopatrina, and Lonsdaleia.

\section{ACKNOWLEDGMENTS}

I am indebted to P. M. Kier and R. E. Grant of the U.S. National Museum of Natural History for making Hayasaka's types and other specimens available to me for study. I am also grateful to P. Semenoff-TianChansky of the Muséum National d'Histoire Naturelle in Paris and to N. V. Kabakovich and T. A. Sayutina of the Paleontologic Institute of the U.S.S.R. Academy of Sciences in Moscow for courtesies extended to me during visits to study material in their care. Many of the ideas expressed in this paper were discussed with colleagues at the Eighth International Congress of Carboniferous Stratigraphy and Geology in Moscow and the Third International Symposium on Fossil Corals in Paris, 1975; N. P. Vasilyuk, E. W. Bamber, M. Minato, M. Kato, P. K. Sutherland, and J. Fedorowski provided useful suggestions and criticisms. M. Minato and M. Kato provided me with photographs of the holotype of the type species of Lithostrotionella and translations of some of Hayasaka's short papers in Japanese. E. C. Wilson provided information on some Pacific Coast localities and specimens. B. L. Mamet identified foraminifers in some collections. I am also indebted to the following for searching collections in their care for type material: J. A. Stitt, University of Missouri; L. S. Kent, Illinois Geological Survey; H. R. Cramer, Emory University; A. Horowitz, Indiana University; D. B. Macurda, University of Michigan; and R. R. Shrock, Massachusetts Institute of Technology. K. R. Moore and H. I. Saunders searched the collections of the U.S. Geological Survey and U.S. National Museum of Natural History for specimens used in this study. K. R. Moore also made thin sections and photographs of the specimens.

\section{THE STATUS OF LITHOSTROTIONELLA}

Yabe and Hayasaka (1915, p. 94-96, 133-134) originally proposed Lithostrotionella as a subgenus of Lithostrotion for a cerioid coral having a lamellar columella and differing from true Lithostrotion by having a lonsdaleoid dissepimentarium. They described, but did not illustrate, the type species (by monotypy) Lithostrotion (Lithostrotionella) unicum from the Carboniferous(?) of Yun-nan Province, China. They suggested that Petalaxis Milne-Edwards and Haime might be a senior synonym but concluded that Petalaxis is identical with true Lithostrotion. In 1920, the same authors (Yabe and Hayasaka, p. 11, pl. 9, figs. 12a, b) illustrated two thin sections of the type species, but both thin sections were cut obliquely with respect to the axes of the corallites, making it difficult to interpret internal structures.

Chi (1931, p. 28-29) raised the name to generic rank for a species from the Middle Carboniferous Weiningian System of Kuechow Province, China, and Yü (1933, p. 101-102) described two species of Lithostrotionella from the Lower Carboniferous of Kuechow Province. Dobrolyubova (1935b, p. 10-20) described species from the Middle Carboniferous of the Moscow Basin and, later (1936a, p. 9, 28, 66), from the Upper Carboniferous of the Urals. This early work set the stage for Hayasaka's (1936) monograph of Lithostrotionella in North America.

Meanwhile, Stelechophyllum Tolmachev was ignored, even by Soviet students, until Hill (1956, p. F286) treated it as a distinct genus and Dobrolyubova and Kabakovich (1962) used the name for corals from the Kuznetsk Basin. The interpretation of Petalaxis MilneEdwards and Haime at that time was based on an erroneous designation of Petalaxis portlocki MilneEdwards and Haime as type species by Hill (1940, p. $165,166)$, who had overlooked Roemer's $(1883$, p. 387 , 388) designation of $P$. maccoyanus Milne-Edwards and Haime as type species. $P$. portlocki is a Lithostrotion, whereas $P$. maccoyanus has a lonsdaleoid dissepimentarium and cannot be referred to Lithostrotion.

Recent work has not unequivocally resolved the morphology of the type species or the most practical limits of the generic concept. Easton (1973) revived Acrocyathus d'Orbigny, redescribed the type specimen of its type species, and concluded that Lithostrotionella is a junior synonym. By this action, Easton simply transferred the highly variable group of corals previously referred to Lithostrotionella to Acrocyathus.

Minato and Kato (1974, p. 67-75) restudied the holotype of Lithostrotionella unicum. All that remains of the original type material is one of the oblique thin sections originally illustrated by Yabe and Hayasaka (1920, pl. 19, fig. 12a). Minato and Kato concluded that 
THE STATUS OF LITHOSTROTIONELLA

TABLE 1. - Hayasaka (1986) type specimens of Lithostrotionella

\begin{tabular}{|c|c|c|c|c|c|c|}
\hline $\begin{array}{c}\text { Hayasaka } \\
\text { species } \\
\text { identification }\end{array}$ & $\begin{array}{l}\text { Kind of } \\
\text { type specimen }\end{array}$ & $\begin{array}{c}\text { Revised } \\
\text { identification }\end{array}$ & $\begin{array}{l}\text { USNM } \\
\text { No. }\end{array}$ & $\begin{array}{l}\text { USGS } \\
\text { Loc. No. }\end{array}$ & $\begin{array}{l}\text { Revised stratigraphic level, age, and } \\
\text { and location (see Register of USGS Localities } \\
\text { (p. 40) for detailed data) }\end{array}$ & $\begin{array}{l}\text { Plate and } \\
\text { page }\end{array}$ \\
\hline \multirow[t]{9}{*}{ americana } & Holotype & Acrocyathus floriformis floriformis d'Orbigny & 120240 & $2333-\mathrm{PC}$ & $\begin{array}{l}\text { St. Louis Limestone, Late Mississippian } \\
\text { (Viséan), Kentucky. }\end{array}$ & Pl. 5; p. 17 \\
\hline & Paratype ------ & Acrocyathus floriformis floriformis d'Orbigny? & 120241 & $1211 \mathrm{~B}-\mathrm{PC}$ & $\begin{array}{l}\text { St. Louis Limestone, Late Mississippian } \\
\text { (Viséan), Missouri. }\end{array}$ & Pl. $6 ;$ p. 17 \\
\hline & ----do & Acrocyathus floriformis floriformis d'Orbigny? & 162001 & 498-PC & $\begin{array}{l}\text { St. Louis Limestone, Late Mississippian } \\
\text { (Visean), Illinois. }\end{array}$ & Pl. $6 ;$ p. 17 \\
\hline & -..-- do & Indet. lithostrotionelloid coral & 174371 & $\begin{array}{l}\text { 3858-PC (green } \\
\text { label) }\end{array}$ & $\begin{array}{l}\text { McCloud Limestone, Early Permian, } \\
\text { California. }\end{array}$ & \\
\hline & ----do & Stelechophyllum banffense (Warren)? & 174372 & $7130 \mathrm{~B}-\mathrm{PC}$ & $\begin{array}{l}\text { Alapah Limestone(?), Late Mississippian } \\
\text { (Viséan), Alaska. }\end{array}$ & Pl. 3; p. 13 \\
\hline & _..._do _. & Indet. lithostrotionelloid coral & 174373 & $\begin{array}{l}3890-\mathrm{PC} \text { (green } \\
\text { label) }\end{array}$ & $\begin{array}{l}\text { McCloud Limestone, Early Permian, } \\
\text { California. }\end{array}$ & --------- \\
\hline & -...- do & Stelechophyllum banffense (Warren)? & 174374 & $970-\mathrm{PC}$ & $\begin{array}{l}\text { Alapah Limestone(?), Late Mississippian } \\
\text { (Viséan), Alaska. }\end{array}$ & Pl. $3 ;$ p. 13 \\
\hline & ---_do _-_------ & Stelechophyllum banffense (Warren)? & 174375 & $3024-\mathrm{PC}$ & $\begin{array}{l}\text { Little Flat Formation, Late Mississippian } \\
\text { (Viséan), Idaho. }\end{array}$ & Pl. 4; p. 13 \\
\hline & ---- do & Acrocyathus floriformis floriformis d'Orbigny & 174376 & 499-PC & $\begin{array}{l}\text { St. Louis Limestone, Late Mississippian } \\
\text { (Viséan), Illinois. }\end{array}$ & Pl. $5 ;$ p. 17 \\
\hline \multirow[t]{9}{*}{ castelnaui_--_- } & Holotype & Acrocyathus floriformis floriformis d'Orbigny & 120235 & 499-PC & $\begin{array}{l}\text { St. Louis Limestone, Late Mississippian } \\
\text { (Viséan), Illinois. }\end{array}$ & Pl. $7 ;$ p. 17 \\
\hline & Paratype & $\begin{array}{l}\text { Acrocyathus floriformis hemisphaericus } \\
\text { (Hayasaka) }\end{array}$ & 120236 & $3282-\mathrm{PC}$ & $\begin{array}{l}\text { Hillsdale Member of Greenbrier Limestone, } \\
\text { Late Mississippian (Viséan), West Virginia. }\end{array}$ & Pl. 14; p. 00 \\
\hline & ---- do _ & Acrocyathus floriformis floriformis d'Orbigny & 161989 & $2226-\mathrm{PC}$ & $\begin{array}{l}\text { St. Louis Limestone, Late Mississippian } \\
\text { (Viséan), Illinois. }\end{array}$ & Pl. 9; p. 17 \\
\hline & -...-do - & Acrocyathus floriformis floriformis d'Orbigny & 161990 & $346 \mathrm{C}-\mathrm{PC}$ & $\begin{array}{l}\text { Residual chert from Tuscumbia Limestone, } \\
\text { Late Mississippian (Viséan), Alabama. }\end{array}$ & Pl. 8; p. 17 \\
\hline & ---- do & Acrocyathus floriformis floriformis d'Orbigny & 161991 & 643-PC & $\begin{array}{l}\text { St. Louis Limestone(?), Late Mississippian } \\
\text { (Viséan), Missouri. }\end{array}$ & Pl. 8; p. 17 \\
\hline & & $\begin{array}{l}\text { Acrocyathus floriformis hemisphaericus } \\
\text { (Hayasaka) }\end{array}$ & 161992 & $2020 \mathrm{~A}-\mathrm{PC}$ & $\begin{array}{l}\text { Greenbrier Limestone, Late Mississippian } \\
\text { (Viséan), Virginia. }\end{array}$ & Pl. $14 ;$ p. 00 \\
\hline & --- do $_{-}$ & Acrocyathus floriformis floriformis d'Orbigny & 161993 & $3159-\mathrm{PC}$ & $\begin{array}{l}\text { Newman Limestone, Late Mississippian } \\
\text { (Viséan), Virginia. }\end{array}$ & Pl. $10 ;$ p. 17 \\
\hline & - do $_{-}$ & Acrocyathus floriformis floriformis d'Orbigny & 161994 & 2013B-PC & $\begin{array}{l}\text { Greenbrier Limestone, Late Mississippian } \\
\text { (Viséan), Virginia. }\end{array}$ & Pl. 9; p. 17 \\
\hline & _-_-_do & $\begin{array}{l}\text { Acrocyathus floriformis floriformis d'Or- } \\
\text { bigny? }\end{array}$ & 174377 & $\begin{array}{l}\text { 3946-PC (green } \\
\text { label) }\end{array}$ & $\begin{array}{l}\text { Unknown, probably St. Louis Limestone, } \\
\text { Mississippi Valley region. }\end{array}$ & Pl. $7 ;$ p. 17 \\
\hline floriformis --- & Holotype & Stelechophyllum banffense (Warren) & 120242 & $3760-\mathrm{PC}$ & $\begin{array}{l}\text { Peratrovich Formation, Late Mississippian } \\
\text { (Viséan), Alaska. }\end{array}$ & $\begin{array}{l}\text { See Armstrong } \\
\text { (1970a) }\end{array}$ \\
\hline \multirow[t]{5}{*}{ girtyi _-_...-- } & -.... do & Acrocyathus girtyi (Hayasaka) & 120243 & $\begin{array}{l}4801 \mathrm{H}-\mathrm{PC} \text { (green } \\
\text { label) }\end{array}$ & $\begin{array}{l}\text { Little Flat Formation, Late } \\
\text { Mississippian (Viséan), Utah. }\end{array}$ & Pl. 17, p. 21 \\
\hline & Paratype & Petalaxis exiguus n. sp. & $162002 \mathrm{~A}, \mathrm{~B}$ & $\begin{array}{l}\text { 3856-PC (green } \\
\text { label) }\end{array}$ & $\begin{array}{l}\text { McCloud Limestone, Early Pemian, } \\
\text { California. }\end{array}$ & Pl. $19 ;$ p. 28 \\
\hline & -.-_do & Stelechophyllum microstylum (White)? & 162003 & $3864-\mathrm{PC}$ & $\begin{array}{l}\text { Lodgepole Limestone, Early Mississippian } \\
\text { (Tournaisian), Montana. }\end{array}$ & Pl. 2; p. 11 \\
\hline & ---_do & Acrocyathus pilatus n. sp. & 162004 & 499-PC & $\begin{array}{l}\text { St. Louis Limestone, Late Mississipian } \\
\text { (Viséan), Illinois. }\end{array}$ & Pl. 17; p. 19 \\
\hline & $\begin{array}{ll}-.-d_{0} \\
---\end{array}$ & $\begin{array}{l}\text { Specimen lost } \\
\text { do }\end{array}$ & - n & $\begin{array}{l}2111-\mathrm{PC} \\
5077 \mathrm{~A}-\mathrm{PC} \text { (green } \\
\text { label) }\end{array}$ & $\begin{array}{l}\text { Meridian Range, Montana. } \\
\text { Weber Canyon, Utah. }\end{array}$ & 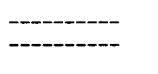 \\
\hline \multirow[t]{9}{*}{ hemisphaerica } & Holotype & $\begin{array}{l}\text { Acrocyathus floriformis hemisphaericus } \\
\text { (Hayasaka) }\end{array}$ & 120237 & $1148-\mathrm{PC}$ & $\begin{array}{l}\text { Granitville, Utah. } \\
\text { St. Louis Limestone, Late Mississippian } \\
\text { (Viséan), Illinois. }\end{array}$ & Pl. $12 ; \mathrm{p} .19$ \\
\hline & Paratype & Acrocyathus floriformis floriformis d'Orbigny & 120238 & $3283-\mathrm{PC}$ & $\begin{array}{l}\text { Hillsdale Member of Greenbrier Limestone, } \\
\text { Late Mississippian (Viséan), West Virginia. }\end{array}$ & Pl. 11; p. 17 \\
\hline & --- do $_{-}$ & Stelechophyllum sp. indet. & 120239 & $5892-\mathrm{PC}$ & $\begin{array}{l}\text { Madison Limestone, Early Mississippian } \\
\text { (Tournaisian), Utah. }\end{array}$ & Pl. $4 ;$ p. 15 \\
\hline & & Acrocyathus floriformis floriformis d'Orbigny & 161995 & 83-PC & $\begin{array}{l}\text { Newman Limestone, Late Mississippian } \\
\text { (Viséan), Kentucky. }\end{array}$ & Pl. 11; p. 17 \\
\hline & $---{ }^{\text {do }}---$ & Stelechophyllum microstylum (White) & 161996 & $1439-\mathrm{PC}$ & $\begin{array}{l}\text { Lodgepole Limestone, Early Mississippian } \\
\text { (Tournaisian), Idaho. }\end{array}$ & Pl. 2; p. 11 \\
\hline & ---- do & Acrocyathus floriformis floriform is d'Orbigny & 161997 & $2020-\mathrm{PC}$ & $\begin{array}{l}\text { Greenbrier Limestone, Late Mississipian } \\
\text { (Viséan), Virginia. }\end{array}$ & Pl. 10; p. 17 \\
\hline & --- do $_{-}$ & $\begin{array}{l}\text { Acrocyathus floriformis hemisphaericus } \\
\text { (Hayasaka) }\end{array}$ & 161998 & $932 A-\mathrm{PC}$ & $\begin{array}{l}\text { St. Louis Limestone, Late Mississippian } \\
\text { (Viséan), Missouri. }\end{array}$ & Pl. 12; p. 19 \\
\hline & & $\begin{array}{l}\text { Acrocyathus floriformis hemisphaericus } \\
\text { (Hayasaka) }\end{array}$ & 161999 & 2222:A-PC & $\begin{array}{l}\text { St. Louis Limestone, Late Mississippian } \\
\text { (Viséan), Illinois. }\end{array}$ & Pl. 13; p. 19 \\
\hline & -..-- do & $\begin{array}{l}\text { Acrocyathus floriformis hemisphaericus } \\
\text { (Hayasaka)? }\end{array}$ & 162000 & 2222.C-PC & $\begin{array}{l}\text { St. Louis Limestone, Late Mississippian } \\
\text { (Viséan), Illinois. }\end{array}$ & Pl. 13; p. 19 \\
\hline \multirow[t]{2}{*}{ multiradiata - } & Holotype & Stelechophyllum microstylum (White) & 120244 & $490-\mathrm{PC}$ & $\begin{array}{l}\text { Lodgepole Limestone, Early Mississipian } \\
\text { (Tournaisian, Utah. }\end{array}$ & Pl. $1 ;$ p. 11 \\
\hline & Paratype & Stelechophyllum microstylum (White) & 162005 & $104-\mathrm{PC}$ & $\begin{array}{l}\text { Lodgepole Limestone, Early Mississippian } \\
\text { (Tournaisian), Idaho. }\end{array}$ & Pl. 1; p. 11 \\
\hline \multirow[t]{2}{*}{ simplex } & Holotype & Petalaxis simplex (Hayasaka) & 120249 & 5893-PC & $\begin{array}{l}\text { Little Flat Formation, Late } \\
\text { Mississippian (Viséan), Utah. }\end{array}$ & Pl. 18; p. 26 \\
\hline & Paratype & Petalaxis wyomingensis n. sp. & 120675 & $\begin{array}{l}\text { 745:-PC (green } \\
\text { label) }\end{array}$ & $\begin{array}{l}\text { "Wells" Formation, Late Mississippian or } \\
\text { Early Pennsylvanian (Namurian), } \\
\text { Wyoming. }\end{array}$ & Pl. 18; p. 26 \\
\hline tabulata _---- & Holotype & Petalaxis tabulatus (Hayasaka) & 120246 & $1476-\mathrm{PC}$ & $\begin{array}{l}\text { Aspen Range Formation, Late Mississippian } \\
\text { (Viséan), Idaho. }\end{array}$ & Pl. $19 ;$ p. 26 \\
\hline \multirow[t]{2}{*}{ tubifera } & --_do & Aulostylus tubiferus tubiferus (Hayasaka) & 120247 & 5894-PC & $\begin{array}{l}\text { Mission Canyon Limestone, Early } \\
\text { Mississippian (Tournaisian), Montana }\end{array}$ & $\begin{array}{l}\text { See Sando } \\
\quad(1976)\end{array}$ \\
\hline & Paratype & Aulostylus tubiferus eotubiferus Sando & 120248 & $3290-\mathrm{PC}$ & $\begin{array}{l}\text { Lodgepole Limestone, Early Mississippian } \\
\text { (Tournaisian), Montana. }\end{array}$ & $\begin{array}{l}\text { See Sando } \\
(1976)\end{array}$ \\
\hline \multirow[t]{2}{*}{ vesicularis _-- } & Holotype & Stelechophyllum banffense (Warren) & 120245 & 3747C-PC & $\begin{array}{l}\text { Peratrovich Formation, Late Mississippian } \\
\text { (Viséan), Alaska. }\end{array}$ & $\begin{array}{l}\text { See Armstrong } \\
\text { (1970a) }\end{array}$ \\
\hline & Paratype ------ & Specimen lost & ------ & $970-\mathrm{PC}(?)$ & Porcupine-Arctic section, Alaska(?) & --------- \\
\hline
\end{tabular}


the geologic age of the type specimen is probably Carboniferous. According to these writers, Lithostrotionella and Acrocyathus are distinct and separate genera, Stelechophyllum is a junior synonym of Lithostrotionella, Eolithostrotionella is a junior synonym of Acrocyathus, and Petalaxis is a junior synonym of Lithostrotion.

The single surviving thin section of the holotype (Minato and Kato, 1974, pl. 15, fig. 1) does not permit an unequivocal evaluation of all the critical internal characters of the type species of Lithostrotionella. However, the corallite in the upper left-hand corner of the slide has what appear to be conical tabulae like those of Acrocyathus and shows no peripheral tabellae. The tabularium is certainly not that of Stelechophyllum or Petalaxis. Although none of the corallites show clearly defined septal lamellae, septal lamellae are not present in all corallites of some species of Acrocyathus.

I conclude that the type species of Lithostrotionella is most likely a species of Acrocyathus; therefore, I regard Lithostrotionella as a probable junior synonym of Acrocyathus. This action, although debatable, is the most practical solution to the nomenclatural problem because both Acrocyathus and Stelechophyllum are founded on well-described and well-illustrated specimens whose ages are well documented. Although the holotype of the type species of Petalaxis is lost and a neotype remains to be selected, the species is well established on topotypes (Sutherland, 1977).

\section{CLASSIFICATION}

Species that have been referred previously to Lithostrotionella Yabe and Hayasaka are reassigned to the following genera in this report: Acrocyathus d'Orbigny (including probable junior synonym Lithostrotionella Yabe and Hayasaka), Stelechophyllum Tolmachev (including junior synonym Eolithostrotionella Zhizhina), Petalaxis Milne-Edwards and Haime (including junior synonyms Hillia de Groot and Eastonoides Wilson and Langenheim), Aulostylus Sando, Kleopatrina McCutcheon and Wilson, Lonsdaleia McCoy (subgenus Actinocyathus d'Orbigny), and Thysanophyllum Nicholson and Thomson. One of the species referred to Cystolonsdaleia Fomichev is reassigned to Petalaxis.

Recent classification of the generic taxa recognized herein is in a state of flux, and there has been little agreement on their familial relations. Acrocyathus was referred to the Family Lonsdaleiidae Chapman by Hill (1956) (as a questionable senior synonym of Lithostrotionella), Easton (1973), and by Ivanovskiy (1975) (as a junior synonym of Lonsdaleia). Dobrolyubova and Kabakovich (1962) regarded Acrocyathus as a ques- tionable junior synonym of Lithostrotion and referred it to the Family Lithostrotionidae d'Orbigny.

Lithostrotionella was referred to the Family Lonsdaleiidae by Hill (1956), Easton (1973) (as a junior synonym of Acrocyathus), de Groot (1964), Armstrong (1970a, b; 1972a, b), and Ivanovskiy (1975). It was placed in the Family Lithostrotionidae by Easton and Gutschick (1953) (as a junior synonym of Lithostrotion) and by Dobrolyubova and Kabakovich (1962). Easton (1958) placed Lithostrotionella in the Family Lithostrotionidae Grabau. The genus was placed in Family Petalaxidae Fomichev by Pyzh'anov (1964) (as a junior synonym of Petalaxis) and by Onoprienko (1970, 1976).

Stelechophyllum was referred to the Family Lithostrotionidae by Hill (1956) and to the Family Lonsdaleiidae by Ivanovskiy (1975) (as a junior synonym of $L$ ithostrotionella). Dobrolyubova and Kabakovich (1962, 1966) placed this genus in the Family Endophyllidae Torley because of its inferred derivation from Endophyllum, a Devonian genus that they recognized as ranging into the Lower Carboniferous.

Eolithostrotionella was referred to the Family Lithostrotionidae by Zhizhina (1956) and in Bul'vanker and others (1960), by Vasilyuk (1960), and by Dobrolyubova and Kabakovich (1962) (as a junior synonym of Lithostrotionella). It was placed in the Family Lonsdaleiidae by Easton (1973) (as a questionable junior synonym of Acrocyathus), by Degtyarev (1973), and by Ivanovskiy (1975) (as a junior synonym of Lithostrotionella). Dobrolyubova and Kabakovich (1966) regarded it as a junior synonym of Stelechophyllum and placed it in the Family Endophyllidae. Pyzh'anov (1964), Onoprienko (1970), and Kozyreva (1974) placed this genus in the Family Petalaxidae. Fedorowski and Gorianov (1973) placed it in the Family Lonsdaleiidae.

Petalaxis was referred by Hill (1956) (as a junior synonym of Lithostrotion) and by Ivanovskiy (19'75) (as a junior "synonym of Lithostrotion) to the Family Lithostrotionidae, on the basis of an erroneous typespecies designation. Fomichev (1953), Dobrolyubova and Kabakovich (1962), Pyzh'anov (1964), Onoprienko (1970), and Kozyreva (1974) placed this genus in the Family Petalaxidae. Fedorowski and Gorianov (1973) placed it in the Family Lonsdaleiidae.

Hillia was referred to the Family Lonsdaleiidae by de Groot (1964) (as a subgenus of Lithostrotionella) and by Easton (1973) (questionably). Ivanovskiy (1975) regarded it as a questionable junior synonym of Lithostrotion and placed it in the Family Lithostrotionidae.

Eastonoides was referred to the Family Lonsdaleiidae by Wilson and Langenheim (1962).

Aulostylus was placed in the Family Lithostrotionidae by Sando (1976). 
Kleopatrina was referred to the Family Durhaminidae Minato and Kato by Minato and Kato (1965) and by Ivanovskiy (1975).

Lonsdaleia was placed in the Family Lonsdaleiidae by Hill (1956), Vasilyuk (1960), Dobrolyubova and Kabakovich (1962), de Groot (1964), and Ivanovskiy (1975).

Thysanophyllum was referred to the Family Lonsdaleiidae by Hill (1956), Armstrong (1970a, b), Degtyarev (1973), and Ivanovskiy (1975). Dobrolyubova and Kabakovich (1962) placed it in the Family Lithostrotionidae. Pyzh'anov (1964) and Onoprienko $(1970,1976)$ referred it to the Family Petalaxidae.

In this report, the following classification is used:

Order Rugosa Milne-Edwards and Haime, 1850

Suborder Columnariina Rominger, 1876

Family Lithostrotionidae d'Orbigny, 1851

Genus Stelechophyllum Tolmachev, 1933 (junior synonym

Eolithostrotionella Zhizhina in Fomichev, 1955)

$S$. ascendens species group

S. ascendens (Tolmachev, 1924)

$S$. ascendens simplex Dobrolyubova in

Dobrolyubova and Kabakovich, 1966

S. ascendens ascendens (Tolmachev, 1924)

S. megalum (Tolmachev, 1924)

S. grande (Tolmachev, 1924)

S. venukoffi (Tolmachev, 1924)

S. venukoffi venukoffi (Tolmachev, 1924)

S. venukoffi altaicum (Tolmachev, 1924)

S. microstylum species group

S. microstylum (White, 1880a)

S. circinatum (Easton and Gutschick, 1953)

S. longiseptatum (Lisitsyn, 1925)

S. banffense (Warren, 1927)

S. micrum species group

S. micrum (Kelly, 1942)

S. lochmanae (Armstrong, 1962)

S. ergunjaicum (Onoprienko, 1976)

$S . ?$ mclareni species group

S.? mclareni (Sutherland, 1958)

S.? birdi (Armstrong, 1970a)

S.? niakensis (Armstrong, 1972a)

S.? macouni species group

S.? macouni (Lambe, 1899)

$S$. sp. indet.

$S$. ? sp. indet.

Genus Aulostylus Sando, 1976

A. tubiferus (Hayasaka, 1936)

A. tubiferus tubiferus (Hayasaka, 1936)

A. tubiferus eotubiferus Sando, 1976

A.? sp.

Family Acrocyathidae new family

Genus Acrocyathus d'Orbigny, 1849a (?junior synonym

Lithostrotionella Yabe and Hayasaka, 1915)

$A$. floriformis d'Orbigny, 1849a

A. floriformis floriformis d'Orbigny, 1849a

A. floriformis hemisphaericus (Hayasaka, 1936)

A. pilatus n. sp.

A. proliferus (Hall in Hall and Whitney, 1858)

A. girtyi (Hayasaka, 1936)

A. pennsylvanicus (Shimer, 1926)
Order Rugosa-Continued

Suborder Columnariina-Continued

Family Acrocyathidae-Continued

Genus Acrocyathus-Continued

A. utkae (Degtyarev, 1973)

A. rotai (Zhizhina in Bul'vanker and others, 1960)

A. cystosus (Zhizhina in Bul'vanker and others, 1960)

A. lissitzini (Zhizhina in Bul'vanker and others, 1960)

A. hsujiulingi (Yoh, 1961)

A.? unicus (Yabe and Hayasaka, 1915)

A.? shimeri (Crickmay, 1955)

A.? grechovkae (Degtyarev, 1973)

A.? zhizhinae (Vasilyuk, 1960)

$A$. spp. indet.

Family Petalaxidae Fomichev, 1953

Genus Petalaxis Milne-Edwards and Haime, 1852 (junior synonyms Hillia de Groot, 1963, and Eastonoides Wilson and Langenheim, 1962)

$P$. simplex species group

P. simplex (Hayasaka, 1936)

$P$. wyomingensis $\mathrm{n}$. sp.

P. tabulatus (Hayasaka, 1936)

P. bailliei (Nelson, 1960)

$P$. flexuosus species group

P. flexuosus (Trautschold, 1879)

P. donbassicus (Fomichev, 1939)

P. mokomokensis (Easton, 1960)

$P$. exiguus n. sp.

$P$. brokawi (Wilson and Langenheim, 1962)

P. monocyclicus (de Groot, 1963)

P. sexangulus (de Groot, 1963)

P. taishakuensis (Yokoyama, 1957)

P. immanis Kozyreva, 1974

P. belinskiensis Fomichev, 1953

P. major (de Groot, 1963)

P. fomichevi n. sp.

P. grootae n. sp.

$P$. wagneri species group

P. wagneri (de Groot, 1963)

$P$. perapertuensis (de Groot, 1963)

$P$. radians (de Groot, 1963)

P. santaemariae (de Groot, 1963)

P. cantabricus (de Groot, 1963)

P. orboensis (de Groot, 1963)

P. occidentalis (Merriam, 1942)

$P$. vesiculosus species group

P. vesiculosus (Dobrolyubova, 1935a)

P. lisitschanskensis (Fomichev, 1953)

P. exilis Kozyreva, 1974

P. confertus Kozyreva, 1974

P. persubtilis Kozyreva, 1974

P. korkhovae Kozyreva, 1974

P. mirus Kozyreva, 1974

$P$. evidens Kozyreva, 1974

$P$. maccoyanus species group

P. maccoyanus Milne-Edwards and Haime, 1851

P. stylaxis (Trautschold, 1879)

P. mohikanus (Fomichev, 1939)

P. celadensis (de Groot, 1963) 
Order Rugosa-Continued

Suborder Columnariina-Continued

Family Petalaxidae-Continued

Genus Petalaxis-Continued

$P$. maccoyanus species group-Continued

$P$. elyensis (Wilson and Langenheim, 1962)

$P$. dobrolyubovae n. sp.

$P$. donetsensis n. sp.

P. ivanovi (Dobrolyubova, 1935a)

$P$.? spp., indet.

Family Lonsdaleiidae Chapman, 1893

Genus Thysanophyllum Nicholson and

Thomson, 1876

T. astraeiforme (Warren, 1927)

Genus Lonsdaleia McCoy, 1849

Subgenus Actinocyathus d'Orbigny, $1849 \mathrm{a}$

L. (A.) berthiaumi (Merriam, 1942)

L. (A.) peratrovichensis (Armstrong, 1970a)

Family Durhaminidae Minato and Kato, 1965

Genus Kleopatrina McCutcheon and Wilson, 1963

Subgenus Kleopatrina McCutcheon and Wilson, 1963

$K$. $(K$.$) ? dilatata (Easton, 1960)$

$K$. (K.)? uralica (Dobrolyubova, 1936a)

K. (K.)? wahooensis (Armstrong, 1972b)

Undetermined lithostrotionelloid corals

The foregoing classification of lithostrotionelloid corals follows Hill (1956) at the ordinal and subordinal level. Placement of Stelechophyllum in the Family Lithostrotionidae also follows Hill (1956). Aulostylus is placed in the Lithostrotionidae because of its close relationship to Stelechophyllum. The recognition of Family Petalaxidae including only Petalaxis and Cystolonsdaleia conforms to Fomichev's (1953) original definition and the subsequent acceptance by Dobrolyubova and Kabakovich (1962). A new family, the Acrocyathidae, is proposed to include only the genus Acrocyathus, which appears to have been derived from Stelechophyllum. Only a few species are allocated to Thysanophyllum, Lonsdaleia (Actinocyathus), and Kleopatrina (Kleopatrina), which are not closely related to the main stock of lithostrotionelloid corals. Thysanophyllum and Lonsdaleia are placed in the Family Lonsdaleiidae following Hill (1956), and Kleopatrina is placed in the Family Durhaminidae following Minato and Kato (1965).

\section{PHYLOGENY}

Hill's $(1938$, p. 35) statement that "little is known of the phylogeny of the Rugosa" is still valid today. In the absence of general agreement on the composition of families, it is very difficult to sketch out even the main phylogenetic lines. Hill (1938, p. 35-36) listed five methods of approach to the phylogeny of genera and species in Rugosa: (1) morphologic comparison without strict attention to detailed stratigraphic chronology; (2) the adult "Formenreihe" method used by Vaughan in his studies of the Rugosa, in which adult characters are traced through a stratigraphic sequence of species; (3) the "Formenreihe" method used by Carruthers in his classic studies of Zaphrentis, in which Haeckel's law of recapitulation is used on a stratigraphic succession of species; (4) deduction of phylogeny of individual species from their ontogeny and checking this against stratigraphic evidence; and (5) deduction of phylogeny of individual species from ontogeny without detailed stratigraphic evidence. Unfortunately, few studies have been made of colonial Rugosa in the Carboniferous by any of these methods. Nevertheless, it is useful to speculate on how the lithostrotionelloid corals are related phylogenetically.

The lithostrotionelloid corals may be divided into two groups of genera, those that seem to be closely related phylogenetically, and those that seem to be independent unrelated forms. In the first group are species allocated to Stelechophyllum, Aulostylus, Acrocyathus, and Petalaxis (fig. 1), which are characterized by a lonsdaleoid dissepimentarium, tabulae that range from tent-shaped to conical to horizontal, and an axial structure that ranges from a simple axial plate ordinarily connected to the counter septum to a complex spider-web structure made up of axial plate, vertical axial tabellae, and septal lamellae.

The origin of the first group of lithostrotionelloid corals is uncertain. The earliest member of this group is Stelechophyllum, which has a lonsdaleoid dissepimentarium, a simple columella, and tent-shaped tabulae. According to Soshkina, Dobrolyubova, and Kabakovich (1962, p. 342), Stelechophyllum was derived from Endophyllum Milne-Edwards and Haime, a Middle Devonian coral that they considered to range into the Tournaisian of Novaya Zemlya. The occurrence of Endophyllum in the Carboniferous apparently was based on Gorskiy's (1935, p. $49-56 ; 1938$, p. 21-24) description of species from the Etroeungtian beds of Novaya Zemlya, which Gorskiy regarded as lower Tournaisian (most Carboniferous and Devonian stratigraphers now regard the Etroeungtian as latest Devonian). True Middle Devonian Endophyllum has a lonsdaleoid dissepimentarium, major septa that approach the axis of the corallites but do not meet or form a columella, and flat tabulae that have down-turned margins (see Jones, 1929). Gorskiy's $(1935,1938)$ colonial species are more like Stelechophyllum than Endophyllum in the nature of their tabulae but do not have a columella. Some species of Stelechophyllum have a poorly developed columella (for example, $S$. ascendens, $S$. megalum, and $S$. grande). It seems more reasonable to refer Gorskiy's species 

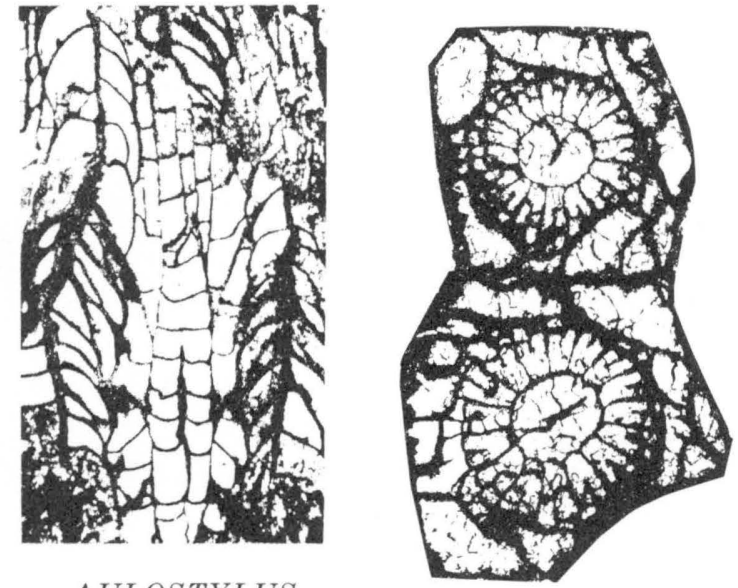

AULOSTYLUS
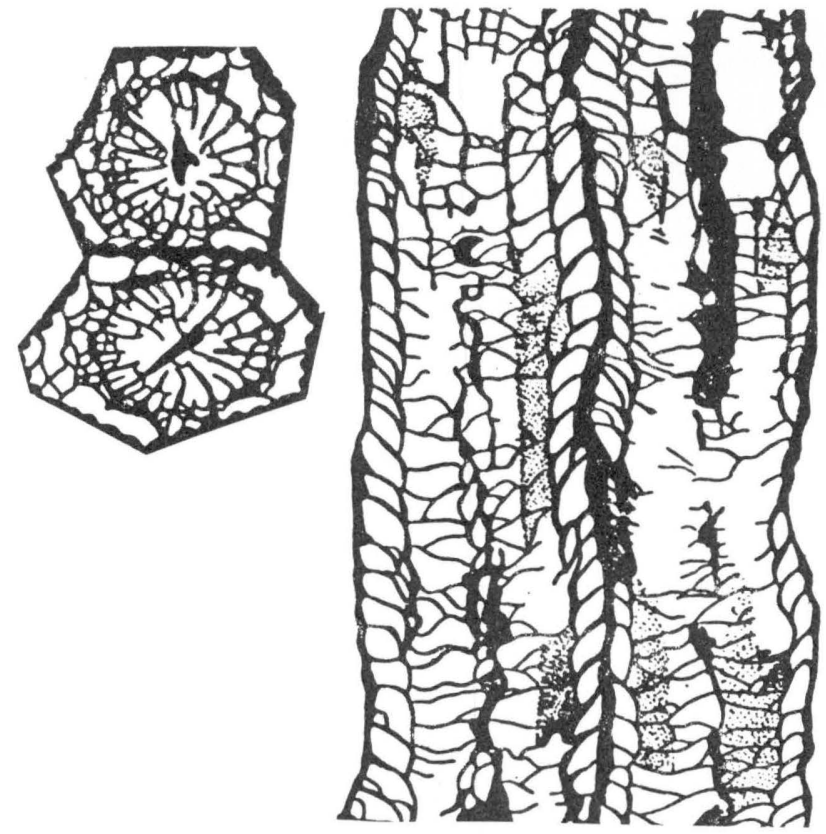

PETALAXIS
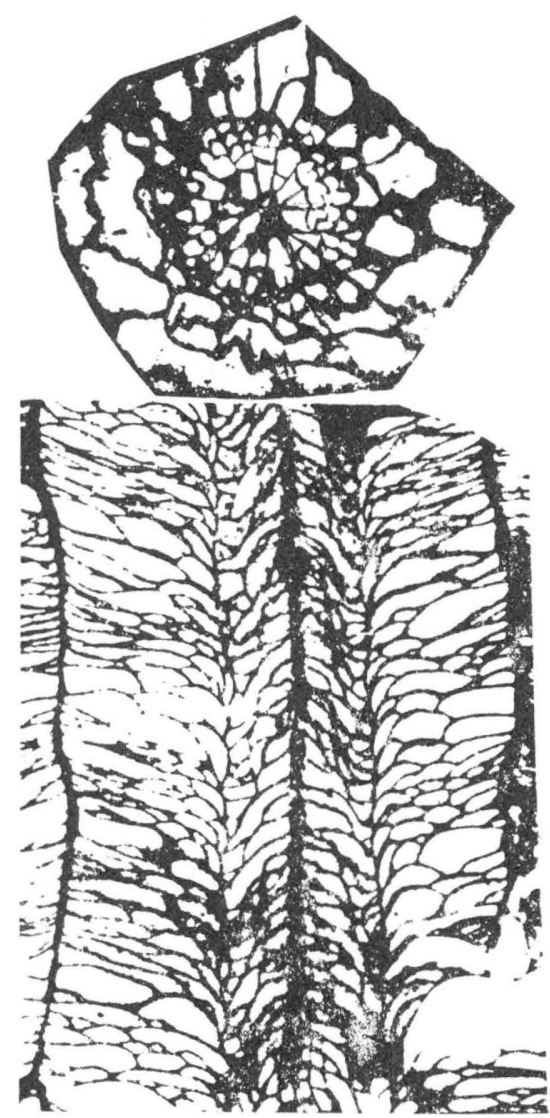

STELECHOPHYLLUM

Figure 1.-Morphology of the type species of the principal lithostrotionelloid genera. Acrocyathus: longitudinal and transverse thin sections $(\times 4)$ of A. floriformis floriformis d'Orbigny (USNM 120235). Stelechophyllum: longitudinal and transverse thin section $(\times 4)$ of S. venukoffi altaicum (Tolmachev) (from Dobrolyubova and Kabakovich, 1966). Petalaxis: longitudinal and transverse thin sections ( $\times 4$ ) of P. maccoyanus Milne-Edwards and Haime (from Fedorowski and Gorianov, 1973). Aulostylus: longitudinal and transverse thin sections (× 6) of A. tubiferus tubiferus (Hayasaka) (from Sando, 1976). 
questionably to Stelechophyllum and to regard them as possible derivatives of the Middle Devonian $E n$ dophyllum.

If the Famennian forms in Novaya Zemlya are referred questionably to Stelechophyllum, then there is a gap until the middle Tournaisian, when true Stelechophyllum appears and ranges into the upper Viséan (fig. 2). In the middle and upper Tournaisian, the axial structure was modified to an aulos in Aulostylus, which is a closely related offshoot of Stelechophyllum. Increased complexity of the axial structure and the formation of conical tabulae took place in Acrocyathus, which ranges through most of the Viséan. Acrocyathus seems to be an offshoot of Stelechophyllum rather than a member of the Lonsdaleiidae, although it may have been the ancestor of Lonsdaleia (Actinocyathus). The earliest species of Petalaxis, which occur in the upper Viséan, are similar to Stelechophyllum in the morphology of their septa and columella, but they have horizontal tabulae. Petalaxis continues upward to the top of the Middle Carboniferous (Moscovian), but there is a gap in its record of occurrence in the Upper Carboniferous before it is seen again in the Permian. The Permian species are very similar to Middle Carboniferous species. The significance of the gap is not now understood; the Permian forms may be merely homeomorphs in an unrelated phylogenetic stock.

The second group of lithostrotionelloid corals includes two phylogenetic stocks that do not seem to be related to Stelechophyllum. Some species previously assigned to Lithostrotionella are herein placed in Lonsdaleia and Thysanophyllum, which are members of the Family Lonsdaleiidae. The origin of Lonsdaleia, which first appears at the top of the Tournaisian (Hill, 1940, p. 151), has been variously linked to Clisiophyllum (Vaughan, 1905, p. 184), Carcinophyllum (Vaughan, 1906, p. 148), and Thysanophyllum (Carruthers, in Garwood, 1912, p. 563; Smith, 1916, p. 235). However, E. W. Bamber (written commun., 1980) has pointed out that Acrocyathus pennsylvanicus and $A$. shimeri have axial structures and tabulation similar to those of the North American species of Lonsdaleia (Actinocyathus), that is, $L$. (A.) stelcki and L. (A.) peratrovichensis. Although these similarities suggest derivation of Lonsdaleia (Actinocyathus) from Acrocyathus in the Viséan of North America, they are inconsistent with the earliest occurrence of Lonsdaleia in the upper Tournaisian of Great Britain. Thysanophyllum is characterized by a discontinuous axial structure and may be polyphyletic (Hill, 1940 , p. 161). For the present, the origins of Lonsdaleia and Thysanophyllum and their possible relationships to the Stelechophyllum stock remain obscure.

Other Carboniferous corals previously assigned to Lithostrotionella are placed herein in Kleopatrina, a predominantly Permian genus. According to Minato and Kato (1965, test-fig. 4), Kleopatrina was derived from Durhamina, and all the members of the Durhaminidae were ultimately derived from the Lithostrotionidae in the Lower Carboniferous. Hence, Kleopatrina does not seem to be closely related to the main stock of lithostrotionelloid corals.

\section{SYSTEMATIC PALEONTOLOGY}

Morphologic terminology is generally that of Hill (1956). The term "tent-shaped" refers to tabulae that slope peripherally from their intersection with the columella at a slight angle to a distinct rounded shoulder, where they are vertical (see Stelechophyllum in fig. 1). These tabulae ordinarily terminate peripherally at a zone of horizontal tabellae without reaching the inner margin of the dissepimentarium and rest one upon the other. The term "conical" refers to tabulae that slope peripherally from their intersection with the columella at a moderate to steep angle without distinct shoulders and reach the inner margin of the dissepimentarium (see

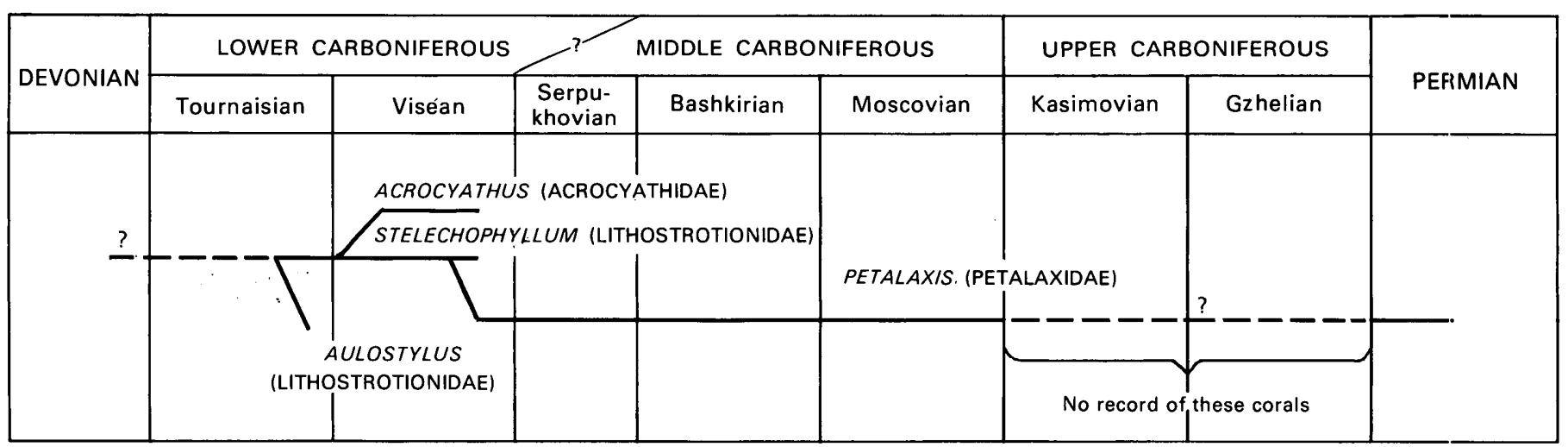

FIGURE 2.- Postulated phylogeny of the principal genera of lithostrotionelloid corals. 
Acrocyathus in fig. 1). Convex or bell-shaped tabulae are like tent-shaped tabulae but are horizontal at the top where they intersect the columella. All types of tabulae are commonly seen in the same specimen, but ordinarily one type dominates. Sections that are not in the plane of the axis show tabulae that appear to be progressively flatter as one approaches the periphery of the tabularium.

Because skeletal microstructure has not been described in most of the species diagnosed herein, no attempt is made to include it in the diagnoses of genera. Septal microstructure is described according to the classification of Kato (1963) only in descriptions of type material of new species and subspecies.

The repositories for material studied by the author are the U.S. National Museum of Natural History, Washington, D.C. (USNM), and the Muséum National d'Histoire Naturelle, Paris, France (MNHN, FL). Other material referred to is in the Rijksmuseum van Geologie en Mineralogie at Leiden, The Netherlands (RGM).

Occurrence data are limited to information taken from descriptive studies given in the synonymies of the taxa concerned, unless otherwise indicated. No attempt was made to search out all occurrences in faunal lists or other similar citations of the taxa.

\section{Order RUGOSA Milne-Edwards and Haime, 1850 \\ Suborder COLUMNARINA Rominger, 1876 \\ Family LITHOSTROTIONIDAE d'Orbigny, 1851 \\ Genus STELECHOPHYLLUM Tolmachev, 1933}

Stylophyllum Tolmachev, 1924, p. 316; 1931, p. 606; Fomichev, 1931, p. 43, 72 (not Reuss, 1854).

Stelechophyllum Tolmachev, 1933, p. 287 (replacement name for Stylophyllum Tolmachev); Soshkina, Dobrolyubova, and Kabakovich, 1962, p. 342; Dobrolyubova and Kabakovich, 1962, p. 122; 1966, p. 130; Minato and Kato, 1974, p. 69.

Eolithostrotionella Zhizhina in Fomichev, 1955, p. 303, 304; Zhizhina, 1956, p. 40.

Lonsdaleia McCoy. Lisitsyn, 1925, p. 68.

Lithostrotion Fleming. White, 1880a (1883), p. 159 [part]; Keyes, 1894, p. 124; Lambe, 1899, p. 220; 1901, p. 176; Tolmachev, 1924, p. 314 [part]; Warren, 1927, p. 46 [part]; Easton, 1944, p. 53; McLaren and Sutherland, 1949, p. 631; Bassler 1950, p. 213; Crickmay, 1955 (1961), p. 12 [part]; Nelson, 1960, p. 122 [part].

Lithostrotion [Lithostrotionella]. Bassler, 1950, p. 221; Easton and Gutschick, 1953, p. 19.

Lithostrotionella Yabe and Hayasaka. Hayasaka, 1936, p. 61, 62, 64, 65, 67, 68 [part]; Kelly, 1942, p. 354, 356, 357 [part]; Easton, 1958, p. 31; Nelson, 1960, p. 112, 113, 119, [part]; 1962, p. 170; Bamber, 1961, p. 107 [part]; 1966, p. 9, 14, 17 [part]; Armstrong, 1962, p. 38,39 [part]; 1970a, p. 29, 32, 35 [part]; 1970b, p. 16, 19, 20, 21 25, 26; Easton, 1963, p. 297; Sando, 1969, p. 309; Onoprienko, 1976, p. 29 [part].

Lithostrotion [Lithostrotionella] [Thysanophyllum] Sutherland, 1958, p. 95.

Type species.-Stylophyllum venukofi Tolmachev, 1924 , p. 318 , pl. 19, figs. 9, 10 and 1931, p. 607, pl. 23, fig. 2 (by designation of Tolmachev, 1933, p. 287). Lower
Carboniferous (Tournaisian), Kuznetsk Basin, U.S.S.R.. Diagnosis.-Cerioid corals with tabular to hemispherical growth form. Septa of two orders. Major septa thin, ordinarily extending across tabularium to columella but discontinuous or absent in dissepimentarium. Minor septa absent to variably developed. Columella ordinarily a simple, smooth or serrated, strong, continuous axial rod or plate that may have been derived from one or more septa, but thysanophylloid variants are known. Tabularium ordinarily consisting of an axial series of bell-shaped to tent-shaped complete tabulae resting one upon the other and a weak peripheral series of horizontal or inclined, concave-upward tabellae ("split tabulae" of Soviet authors). Dissepimentarium lonsdaleoid, commonly showing traces or crests of discontinuous septa in transverse section. Increase axial, peripheral, and intermural.

Discussion. - Tolmachev's $(1924,1931)$ original diagnosis of this genus described a coral similar to cerioid Lorisdaleia but without an axial plate and having a false columella formed by arched tabulae. Some of Tolmachev's figures of transverse sections suggest that an axial rod is present, but the point is ambiguous. Hill $(1940$, p. $164 ; 1956$, p. 286$)$ and Cotton $(1973$, p. 195) followed the original diagnosis. However, Fomichev (1931, p. 43, 72) restudied Tolmachev's types and concluded that Tolmachev's longitudinal sections are cuts that do not intersect the axes of the corallites. Fomichev found a columella like that of Lithostrotion in Tolmachev's transverse sections. These observations were confirmed by Fomichev's study of topotypes. Subsequent study by Dobrolyubova and Kabakovich $(1962,1966)$ on specimens from the Kuznetsk Basin confirmed. Fomichev's findings and also showed that the Kuznetsk Basin species form a genetic series from weakly to strongly columellate forms.

Most authors (Hill, 1956, p. F286; Soshkina, Dobrolyubova, and Kabakovich, 1962, p. 342; Dobrolyubova and Kabakovich, 1962, p. 122-124; 1966, p. 130-157; Cotton, 1973, p. 195) regarded Stelechophyllum as a distinct genus, but Wang (1950, p. 212), Ivanovskiy (1967, p. 34), and Minato and Kato (1974, p. 69-71) regarded it as a junior synonym of Lithostrotionella Yabe and Hayasaka. In my opinion, Stelechophyllum is a distinct genus and Lithostrotionella is a probable junior synonym of Acrocyathus d'Orbigny.

Stelechophyllum is differentiated from Acrocyathus and Petalaxis by the nature of its axial structure and tabularium (fig. 1). In Stelechophyllum, the axial structure consists of a simple columella in the form of a rod or plate unmodified by septal lamellae or axial tabellae. The major septa may or may not join the columella, and the columella may be slightly serrated where the septa fall short of it. The tabularium in Stelechophyllum con- 
sists of an axial series of convex to tent-shaped tabulae with well-defined shoulders that rest one upon the other and a weak peripheral zone of more or less horizontal, ordinarily concave-upward tabellae. Acrocyathus has a complex axial structure composed of an axial plate, axial lamellae, and steeply inclined tabulae or tabellae. The major septa seldom extend to the axial complex. The tabulae are essentially conical and ordinarily extend without shoulders to the periphery of the tabularium; peripheral tabellae are rare. Petalaxis has an essentially simple columella like that of Stelechophyllum, although some species have impersistently developed axial tabellae. The tabulae in Petalaxis are essentially horizontal.

Eolithostrotionella Zhizhina was proposed for corals that differ from Lithostrotion by having lonsdaleoid dissepiments and from Lithostrotionella by having arched, rather than horizontal, tabulae. Although the morphology of the type species of Lithostrotionella is in doubt, it seems to have conical tabulae like those of Acrocyathus; at any rate, the tabulae are not horizontal. The type species of Eolithostrotionella has an axial structure identical with the type species of Stelechophyllum and is here placed in the synonymy of Stelechophyllum.

Species of Stelechophyllum are distinguished on differences in mature corallite diameter, number of major septa at maturity, presence or absence and length of minor septa (weak or strong), development of the columella (absent, weak, or strong), major septal extensions into the tabularium (weak or strong), major septal extensions in the dissepimentarium (weak or strong), shape of the axial tabulae (flat, tent-shaped, convex), spacing of the tabulae, development of peripheral tabellae (absent, weak, or strong), number of rows of dissepiments, size and shape of dissepiments (large, small, inflated, flattened), and ratio of tabularium width to corallite diameter.

The species of Stelechophyllum fall into five major groups:

1. S. ascendens group, including ascendens, megalum, grande, and venukoffi. This group is characterized by its large corallites, moderate number of major septa, and by having a variably developed columella. The group is exclusively Tournaisian.

2. S. microstylum group, including microstylum, circinatum, longiseptatum, and banffense. This group is characterized by its large corallites, large number of major septa, and well developed columella. The group is Tournaisian and Viséan.

3. S. micrum group, including micrum, lochmanae, and ergunjaicum. This group is characterized by its small corallites and small number of major septa. The group is Tournaisian and Viséan.
4. S.? mclareni group, including mclareni, birdi, and niakense. This group is characterized by its strongly polymorphic corallites. The group is exclusively Viséan.

5. S.? macouni group, including only $S$.? macouni from the Visean. This group is characterized by its weakly lonsdaleoid dissepimentarium.

Occurrence. - Upper Devonian (Famennian)(?) and Lower Carboniferous, middle Tournaisian to upper Viséan. U.S.S.R., Canada, U.S.A., Mexico.

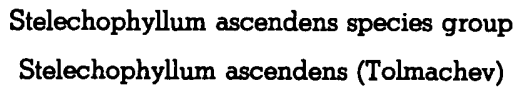

Stylophyllum ascendens Tolmachev, 1924, p. 319, pl. 19, figs. 14, 15; 1931, p. 608, pl. 23, fig. 4

Stelechophyllum ascendens (Tolmachev). Dobrolyubova and Kabakovich, 1962, p. 123, pl. C-5, fig. 11, pl. C-6, figs. 1a, b; 1966, p. 136.

Diagnosis. -Stelechophyllum with corallite diameter 7 to $12 \mathrm{~mm}$ and 13 to 17 major septa that seldom extend into the dissepimentarium. Major septa join the columella or end a short distance from it or from the axis when a columella is absent. Minor septa weakly developed or absent. Columella weakly developed or absent from some corallites. Dissepimentarium composed of a single row of large inflated dissepiments. Axial tabulae flat to strongly convex, spaced 0.5 to $1 \mathrm{~mm}$ apart. Peripheral tabellae absent or weakly developed. Ratio of tabularium width to corallite diameter 0.5 to 0.6 . Increase is peripheral.

Discussion. - This species is distinguished by its weak development of minor septa and columella.

Occurrence.-Lower Carboniferous, upper Tournaisian. Nizhnetersin Horizon, Kuznetsk Basin, U.S.S.R.

Stelechophyllum ascendens simplex Dobrolyubova, in Dobrolyubova and Kabakovich

Stelechophyllum ascendens simplex Dobrolyubova, in Dobrolyubova and Kabakovich, 1966, p. 137, pl. 23, figs. 1, 2, text-fig. 7.

Diagnosis.-Stelechophyllum ascendens in which most of the corallites are without a columella and have tabulae that range from flat (without columella) to tentshaped (with columella).

Description of holotype.-See Dobrolyubova and Kabakovich (1966, p. 137).

Discussion. - This form is the most primitive in the Russian Stelechophyllum sequence (Dobrolyubova and Kabakovich, 1966, p. 134).

Occurrence.-Lower Carboniferous, Tournaisian. Nizhnetersin Horizon, Kuznetsk Basin, U.S.S.R.

Stelechophyllum ascendens ascendens (Tolmachev)

Stelechophyllum ascendens ascendens (Tolmachev). Dobrolyubova and Kabakovich, 1966, p. 139, pl. 24, figs. 1, 2; pl. 25, figs. 1, 2; pl. 28, fig. 3; text-figs. 8, 9. 
Diagnosis.-Stelechophyllum ascendens in which most of the corallites have a columella and axial tabulae and peripheral tabellae are present.

Description of lectotype.-See Tolmachev (1924, p. 319).

Occurrence.-Lower Carboniferous, upper Tournaisian. Nizhnetersin Horizon, Kuznetsk Basin, U.S.S.R.

Stelechophyllum megalum (Tolmachev)

Stylophyllum megalum Tolmachev, 1924, p. 319, pl. 19, figs. 11, 12; 1931 , p. 608 , pl. 23 , fig. 3 .

Stelechophyllum megalum (Tolmachev). Dobrolyubova and Kabakovich, 1962, p. 123, pl. C-5, fig. 1; 1966, p. 143, pl. 26, figs. 1a-c, 2, textfig. 10 .

Diagnosis. -Stelechophyllum with corallite diameter 7 to $14 \mathrm{~mm}$ and 13 to 19 major septa that most commonly extend from the columella across the tabularium and into the dissepimentarium. Minor septa generally well developed. Columella variable in form and thickness, commonly thick and lenticular, in some corallites replaced by ends of one or more major septa, absent from many corallites. Dissepimentarium consists of 1 to 3 poorly defined rows of large and small inflated dissepiments. Axial tabulae tent-shaped, spaced about 5 in $1 \mathrm{~mm}$. Peripheral tabellae well developed. Ratio of tabularium width to corallite diameter about 0.4 . Increase is peripheral.

Description of lectotype.-See Tolmachev (1924, p. 319).

Occurrence.-Lower Carboniferous, upper Tournaisian. Nizhnetersin Horizon, Kuznetsk Basin, U.S.S.R.

\section{Stelechophyllum grande (Tolmachev)}

Lithostrotion grande Tolmachev, 1924, p. 315, pl. 19, fig. 13; 1931, pl. 22 , fig. 6 .

Stelechophyllum grande (Tolmachev) Dobrolyubova and Kabakovich, 1966, p. 146, pl. 27, figs. 1, 2; text-figs. 11-14.

Diagnosis. -Stelechophyllum with corallite diameter 9 to $18 \mathrm{~mm}$ and 13 to 20 major septa that most commonly extend from the columella across the tabularium but seldom extend into the dissepimentarium. Minor septa absent to weakly developed. Columella variable in form and thickness, commonly thick and lenticular, in some corallites replaced by ends of one or more major septa, absent from some corallites. Dissepimentarium consists of 1 to 4 rows of small to large dissepiments. Tabulae spaced 0.5 to $1 \mathrm{~mm}$ apart, variable in form. Peripheral tabellae poorly developed. Ratio of tabularium width to corallite diameter about 0.4 . Increase is peripheral.

Description of lectotype. - See Tolmachev (1924, p. 315).

Occurrence.-Lower Carboniferous, upper Tournaisian. Nizhnetersin Horizon, Kuznetsk Basin, U.S.S.R.
Stelechophyllum venukoffi (Tolmachev)

See subspecies below for synonymy.

Diagnosis.-Stelechophyllum with corallite diameter 5.5 to $15 \mathrm{~mm}$ and 12 to 20 major septa that ordinarily extend from the columella across the tabularium but seldom extend into the dissepimentarium. Minor septa absent to well developed. Columella absent to very thick. Dissepimentarium composed of 1 to 4 rows of small to large dissepiments. Axial tabulae convex to tent-shaped, spaced about $0.5 \mathrm{~mm}$ apart. Peripheral tabellae poorly to well developed. Ratio of tabularium width to corallite diameter about 0.3 to 0.4 . Increase is peripheral, axial, or intermural.

Stelechophyllum venukoffi venukoffi (Tolmachev)

Stylophyllum venukoffi Tolmachev, 1924, p. 318, pl. 19, figs. 9, 10; 1931, pl. 23, fig. 2.

Stelechophyllum venukoffi (Tolmachev). Dobrolyubova and Kabakovich, 1962, p. 124.

Stelechophyllum venukoffi venukoffi (Tolmachev). Dobrolyubova and Kabakovich, 1966, p. 156, pl. 28, figs. 1, 2, text-fig. 15.

Diagnosis.-Stelechophyllum venukoffi with minor septa absent or weakly developed and predominantly large dissepiments.

Description of lectotype.-See Tolmachev (1924, p. 318).

Occurrence.-Lower Carboniferous, upper Tournaisian. Nizhnetersin Horizon, Kuznetsk Basin, U.S.S.R.

Stelechophyllum venukotfi altaicum (Tolmachev)

Lithostrotion altaicum Tolmachev, 1924, p. 314, pl. 19, figs. 7, 8; 1931, pl. 23, fig. 1.

Stelechophyllum venukoffi altaicum (Tolmachev). Dobrolyubova and Kabakovich, 1966, p. 157, pl. 29, figs. 1-3, pl. 30, fig. 1.

Diagnosis.-Stelechophyllum venukoffi with minor septa well developed and variable, predominantly small dissepiments.

Description of lectotype.-See Tolmachev (1924, p. 314).

Discussion.-This subspecies is similar to Stelechophyllum microstylum (White) but has fewer major septa, fewer extensions of the septa in the dissepimentarium, and a lower ratio of tabularium width to corallite diameter.

Occurrence.-Lower Carboniferous, upper Tournaisian. Nizhenetersin Horizon, Kuznetsk Basin, U.S.S.R.

\section{Stelechophyllum microstylum species group \\ Stelechophyllum microstylum (White)}

Plates 1 and 2

Lithostrotion microstylum White, 1880a (1883), p. 159, pl. 40, fig. 7a; Keyes, 1894, p. 124; Easton, 1944, p. 53, pl. 13, figs. 1-3, pl. 17, fig. 1; Bassler, 1950, p. 213, Nelson, 1962, p. 170.

Lithostrotionella microstyla (White). Bamber, 1961, p. 110, pl. 8, figs. 4a, b, pl. 9, figs. 1a-h; Bowsher, 1961, pl. 110, figs. 4, 5a-c; Carlson, 1964, p. 663, pl. 110, figs. 4,6 . 
?Lithostrotionella cf. microstyla (White). Bamber, 1961, p. 121, pl. 9, figs. 2a-e.

Lithostrotionella microstylum (White). Easton, 1963, p. 297; Bamber, 1966, p. 9, pl. 1, figs. 5a-g, pl. 2, figs. 1-3, pl. 3, figs. 1-3.

Lithostrotionella jasperensis Kelly, 1942, p. 356, pl. 51, figs. 3, 6; Nelson, 1960, p. 112, pl. 21, figs. 1-4; 1961, pl. 1, figs. 1-3; 1962, p. 170; Stensaas and Langenheim, 1960, p. 184, text-figs. 9a, b, 10a, b; Easton, 1963, p. 297.

Lithostrotion [Lithostrotionella] jasperensis (Kelly). Bassler, 1950, p. 221.

Lithostrotionella confluens Easton, 1958, p. 31, pl. 1, fig. 12, pl. 2, figs. 8, 9; Armstrong, 1962 , p. 39, text-fig. 18, pl. 4, figs. 1-5, Nelson, 1962, p. 170; Easton, 1963, p. 297.

?Lithostrotionella girtyi Hayasaka, 1936, p. 65 [part].

Lithostrotionella hemisphaerica Hayasaka, 1936, p. 61 [part].

Lithostrotionella multiradiata Hayasaka, 1936, p. 67.

Diagnosis. -Stelechophyllum with corallite diameter 4 to $17 \mathrm{~mm}$ and 15 to 22 major septa that most commonly extend across the tabularium from the columella and into the dissepimentarium. Minor septa well developed. Columella ordinarily very well developed. Dissepimentarium composed of 1 to 10 rows (ordinarily 5 rows) of small to large, commonly flattened dissepiments. Axial tabulae convex to tent-shaped, spaced 2 to 4 in $1 \mathrm{~mm}$. Peripheral tabellae well developed. Ratio of tabularium width to corallite diameter 0.4 to 0.5 . Increase is intermural(?).

Description of neotype. - According to Easton (1944, p. 54), the holotype of $S$. microstylum was probably lost in a fire. USNM specimen 66838, described and illustrated by Bamber (1961, p. 110, pl. 8, figs. 4a, b, pl. 9, figs. la-h; 1966, p. 10-11, pl. 1, figs. 5a-g, pl. 2, figs. 3a, b), is here designated neotype for this species.

Discussion. - This is the most widespread species of Stelechophyllum in North America, ranging from the Mississippi Valley area to western Canada, where its occurrence is exclusively middle and upper Tournaisian (upper Kinderhookian and lower Osagean). $S$. microstylum is distinguished from the Russian species $S$. megalum by its greater maximum corallite diameter, more numerous major septa, ordinarily stronger columella, and more numerous, generally less inflated dissepiments. It is separated from $S$. banffense by its greater maximum corallite diameter, stronger minor septa, more numerous septal extensions into the tabularium, less flattened axial tabulae, and less inflated dissepiments.

Bamber (1966, p. 12-14) has discussed the synonymy of Lithostrotionella jasperensis Kelly and Lithostrotionella confluens Easton with $S$. microstylum, on the basis of study of the type material of these taxa. Three of Hayasaka's (1936) specimens are here referred definitely to $S$. microstylum. These are the holotype and paratype of Lithostrotionella multiradiata Hayasaka, USNM 120244 and 162005, respectively, and a paratype of $L$. hemisphaerica Hayasaka, USNM 161996. A fourth specimen, a paratype of L. girtyi Hayasaka, USNM 162003 , is referred questionably to $S$. microstylum. These specimens are all illustrated herein.

Occurrence. - Lower Carboniferous, middle and upper Tournaisian. Chouteau Limestone and Northview Shale, Missouri, U.S.A.; Gilmore City Limestone, Iowa, U.S.A.; Lodgepole Limestone, Montana(?), Idaho, and Utah, U.S.A.; Joana Limestone, Nevada, U.S.A.; Keating Formation and Lake Valley Limestone, New Mexico, U.S.A.; Represo and Venada Formations, Sonora, Mexico; Banff and Pekisko Formations, Alberta, Canada.

\section{Stelechophyllum circinatum (Easton and Gutschick)}

Lithostrotion (Lithostrotionella) circinatus Easton and Gutschick, 1953, p. 19, pl. 3, figs. 5, 6 [part].

Lithostrotionella circinatus (Easton and Gutschick). Nelson, 1962, p. 170; Easton, 1963, p. 297; Sando, 1969, p. 309, pl. 38, figs. 1-7.

Diagnosis. -Stelechophyllum with corallite diameter 9 to $13 \mathrm{~mm}$ and 21 to 30 major septa that most commonly extend from the columella across the tabularium but seldom extend into the dissepimentarium. Minor septa absent to poorly developed. Columella absent to very well developed. Dissepimentarium composed of 1 to 4 rows of small to large, commonly flattened dissepiments. Axial tabulae flat to tent-shaped, spaced 4 in $1 \mathrm{~mm}$. Peripheral tabellae well developed. Ratio of tabularium width to corallite diameter 0.4 to 0.5 . Increase is peripheral.

Description of type specimens. - See Easton and Gutschick (1953, p. 19).

Discussion. - This species is similar to $S$. microstylum but differs in having more major septa, a columella that is variably developed, and fewer extensions of the major septa into the dissepimentarium. $S$. circinatum occurs at a slightly higher stratigraphic level than $S$. microstylum.

Occurrence.-Lower Carboniferous, upper Tournaisian. Redwall Limestone, Arizona, U.S.A.

Stelechophyllum longiseptatum (Lisitsyn)

Lonsdalia longiseptata Lisitsyn, 1925, p. 68, p. 1, fig. 4.

Eolithostrotionella longiseptata (Lisitsyn). Zhizhina, 1956, p. 40, pl. 9, figs. $1 \mathrm{a}, \mathrm{b}$.

Diagnosis.-Stelechophyllum with corallite diameter 15 to $20 \mathrm{~mm}$ and 24 to 32 major septa that most commonly extend from the columella across the tabularium and into the dissepimentarium. Minor septa well developed. Columella well developed. Dissepimentarium composed of 2 to 5 rows of small to large inflated dissepiments. Axial tabulae convex to tent-shaped, spaced 0.2 to $1 \mathrm{~mm}$ apart. Peripheral tabellae well developed(?). Ratio of tabularium width to corallite diameter 0.4 to 0.5 . Mode of increase unknown. 
Description of holotype. - See Zhizhina (1956).

Discussion. - This species is similar to $S$. circinatum but differs in having larger corallites, more major septa, a stronger columella, and in having the major septa commonly extending into the dissepimentarium.

Occurrence.-Lower Carboniferous, middle Viséan. Zone $\mathrm{C}_{1}{ }^{\mathrm{v}} \mathrm{d}$ Donetz Basin, U.S.S.R.

\section{Stelechophyllum banffense (Warren) \\ Plate 3; plate 4, figures 1,2}

Lithostrotion banffensis Warren, 1927, p. 46, pl. 3, figs. 5, 6, pl. 5; Crickmay, 1955, 1961, p. 12, pl. 1, figs. 13, 14.

Lithostrotionella banffensis (Warren). Kelly, 1942, p. 354; Bamber, 1966, p. 17, pl. 3, fig. 5; Armstrong, 1970a, p. 29, pl. 10, figs. 1-8, pl. 13 , figs. $1-7 ; 1970$ b, p. 16 , pl. 3 , figs. $5-8$, pl. 4 , figs. $1-4$, pl. 10, fig. 1 .

Lithostrotionella banffense (Warren). Nelson, 1960, p. 119, pl. 23, figs. 4,$5 ; 1961$, pl. 17, figs. $1,2$.

Lithostrotionella cf. banffensis (Warren). Bamber, 1961, p. 133, pl. 10, figs. 3a-d.

Lithostrotionella floriformis Hayasaka, 1936, p. 64, pl. 17, figs. 1a, b. Lithostrotionella vesicularis Hayasaka, 1936, p. 68, pl. 14, figs. 3a, b. ?Lithostrotionella americana Hayasaka, 1936, p. 62 [part].

?Lithostrotionella aff. L. banffensis (Warren). Armstrong, 1970b, p. 19, pl. 4, figs. 5, 6 .

Diagnosis. -Stelechophyllum with corallite diameter 6 to $13 \mathrm{~mm}$ and 19 to 26 major septa of variable length that seldom join the columella and seldom extend into the dissepimentarium. Minor septa absent to poorly developed. Columella well developed. Dissepimentarium composed of 1 to 6 rows of small to large inflated dissepiments. Axial tabulae ordinarily broadly tentshaped, spaced 2 to 4 in $1 \mathrm{~mm}$. Peripheral tabellae poorly to well developed. Ratio of tabularium width to corallite diameter 0.5 to 0.6 . Increase is peripheral.

Description of lectotype.-See Nelson (1960) and Bamber (1966).

Discussion. - This highly variable species is common in rocks of early and middle Viséan age in western Canada and Alaska. It appears to have been derived from $S$. microstylum, from which it differs in having smaller corallites, weaker major and minor septa, somewhat flattened tabulae that are variable in form, ordinarily fewer rows of dissepiments, and a larger ratio of tabularium width to corallite diameter.

Armstrong (1970a, p. 29-31) has discussed the synonymy of Lithostrotionella floriformis Hayasaka and Lithostrotionella vesicularis Hayasaka with $S$. banffense on the basis of study of the type material. Hayasaka's type specimens are illustrated in Armstrong's paper. Three paratypes of Lithostrotionella americana (USNM 174372,174374 , and 174375) are here referred to the species with query and are illustrated herein.

Occurrence.-Lower Carboniferous, lower and middle Viséan. Mount Head Formation, Alberta, Canada; Prophet Formation, British Columbia, Canada;
Peratrovich, Nasorak, Kogruk, and Alapah(?) Formations, Alaska, U.S.A.; Little Flat Formation, Idaho, U.S.A.(?).

\section{Stelechophyllum micrum species group}

Stelechophyllum micrum (Kelly)

Lithostrotionella micra Kelly, 1942, p. 357, pl. 50, fig. 7; Nelson, 1960, p. 113, pl. 21, figs. 5, 6; 1961, pl. 6, figs. 1-3; Bamber, 1966, p. 14, pl. 3, figs. 4a-e.

Lithostrotion [Lithostrotionella] micra (Kelly). Bassler, 1950, p. 221 Lithostrotion micra (Kelly). Brindle, 1960, pl. 10, fig. 2.

Diagnosis.-Stelechophyllum with corallite diameter 2 to $6 \mathrm{~mm}$ and 10 to 15 major septa that most commonly extend from the columella across the tabularium but seldom extend into the dissepimentarium. Minor septa poorly developed. Columella poorly to well developed. Dissepimentarium composed of 1 to 2 rows of large inflated dissepiments. Axial tabulae convex, spaced 2 in 1 $\mathrm{mm}$. Peripheral tabellae poorly developed. Ratio of tabularium width to corallite diameter about 0.6. Increase is peripheral(?).

Description of holotype. - See Kelly (1942) and Bamber (1961).

Discussion. - This species is similar to Stelechophyllum lochmanae and S. ergunjaicum. S. lochmanae has larger corallites and stronger major septa. S. ergunjaicum has slightly more major septa and only one row of dissepiments.

Occurrence.-Lower Carboniferous, upper Tournaisian. Pekisko and Shunda Formations, Alberta, Canada.

Stelechophyllum lochmanae (Armstrong)

Lithostrotionella lochmanae Armstrong, 1962, p. 38, pl. 4, figs. 6-8, text fig. 17.

Diagnosis. - Stelechophyllum with corallite diameter 5 to $8 \mathrm{~mm}$ and 13 to 15 major septa that most commonly extend from the columella across the tabularium and into the dissepimentarium. Minor septa well developed. Columella well developed. Dissepimentarium composed of 1 to 2 rows of large inflated dissepiments. Axial tabulae convex, spaced 3 in $1 \mathrm{~mm}$. Peripheral tabellae poorly developed. Ratio of tabularium width to corallite diameter about 0.6. Mode of increase unknown.

Description of type material. - See Armstrong (1962).

Discussion. - This species is similar to S. micrum and S. ergunjaicum. S. micrum has smaller corallites and weaker minor septa, and $S$. ergunjaicum has weaker minor septa and fewer extensions of the major septa into the dissepimentarium.

Occurrence.-Lower Carboniferous, middle Tournaisian. Keating Formation and Lake Valley Limestone, New Mexico and Arizona, U.S.A.

Stelechophyllum ergunjaicum (Onoprienko)

Lithostrotionella ergunjaicum Onoprienko, 1976, p. 29, pl. 11, figs. 3, 4. 
Diagnosis.-Stelechophyllum with corallite diameter 4 to $6 \mathrm{~mm}$ and 15 to 16 major septa that most commonly extend from the columella across the tabularium but seldom extend into the dissepimentarium. Minor septa poorly developed. Columella well developed. Dissepimentarium composed of a single row of large inflated dissepiments. Axial tabulae convex to tentshaped, spaced 0.1-1.2 mm apart. Peripheral tabellae well developed. Ratio of tabularium width to corallite diameter 0.5 to 0.6 . Mode of increase unknown.

Description of type material. - See Onoprienko (1976).

Discussion.-This species is similar to the North American species $S$. lochmanae and $S$. micrum. $S$. ergunjaicum differs from $S$. micrum by having convex to tent-shaped tabulae, better developed peripheral tabellae, and only one row of dissepiments. The Russian species differs from $S$. lochmanae by having smaller corallites, weaker minor septa, fewer extensions of the major septa into the dissepimentarium, and only one row of dissepiments.

Occurrence-Lower Carboniferous, upper Viséan. Utaveem Suite, East Chukotka, Chegitun' River basin, U.S.S.R.

\section{Stelechophyllum? mclareni species group}

Stelechophyllum? mclareni (Sutherland)

Lithostrotion sp. McLaren and Sutherland, 1949, p. 631, pl. 103, figs. 1-9.

Lithostrotion [Lithostrotionella] [Thysanophyllum] mclareni Sutherland, 1958, p. 95, pl. 33, figs. 1a-g.

Lithostrotionella mclareni (Sutherland). Armstrong, 1970b, p. 21, pl. 5 , figs. 4, 7, 8-10, pl. 6, figs. 1, 2, 7-9.

?Lithostrotionella aff. L. mclareni Sutherland. Armstrong, 1970a, p. 35 , pl. 8, figs. 8, 9 .

Diagnosis. -Stelechophyllum? with corallite diameter 3.5 to $4.4 \mathrm{~mm}$ and 12 to 15 major septa of variable length that may or may not join the columella and may or may not extend into the dissepimentarium. Minor septa absent to well developed. Columella weakly developed (or discontinuous) to strongly developed. Dissepimentarium composed of 1 to 3 rows of small to large inflated dissepiments. Axial tabulae flat to tent-shaped, depending on strength of columella, spaced 2 in $1 \mathrm{~mm}$ Peripheral tabellae absent to poorly developed. Ratio of tabularium width to corallite diameter about 0.5. Increase is peripheral.

Description of holotype.-See McLaren and Sutherland (1949).

Discussion.-McLaren and Sutherland (1949), Sutherland (1958), and Armstrong (1970b) have discussed in detail the extreme morphologic variability in this species. According to E. W. Bamber (written commun., 1980), who has studied the species, serial sections of the corallites show vertical discontinuity of the septa in the dissepimentarium and vertical discontinunity of the colummella so that some sections have the appearance of Sciophyllum in corallites that are mainly characterized by the Stelechophyllum structure. The amount of variation is notable in this species.

S.? mclareni is similar to S.? birdi and S.? niakense, from which it differs in corallite diameter, in number of major septa, and in the degree to which the major septa extend into the dissepimentarium Armstrong's (1970a) Lithostrotionella aff. L. mclareni has characters that place it close to $S . ?$ birdi and is here referred to $S$. ? mclareni with query.

Occurrence.-Lower Carboniferous, Viséan. Prophet Formation, British Columbia, Canada; Kogruk Formation, Alaska, U.S.A.

\section{Stelechophyllum? birdi (Ärmstrong)}

Lithostrotionella birdi Armstrong, 1970a, p. 32, pl. 7, figs. 1-4, pl. 8, figs. $1-7$; 1970b, p. 20, pl. 4, fig. 1, pl. 5, figs 1-3, 5, 6 .

Diagnosis.-Stelechophyllum? with corallite diameter 3.5 to $7.5 \mathrm{~mm}$ and 15 to 20 major septa of variable length that seldom join the columella and may or may not extend into the dissepimentarium. Minor septa absent to poorly developed. Columella absent to weakly developed. Dissepimentarium composed of 1 to 2 rows of mostly large inflated dissepiments. Axial tabulae flat to flattened tent-shaped, spaced 2 in $1 \mathrm{~mm}$. Peripheral tabellae absent to poorly developed. Ratio of tabularium width to corallite diameter about 0.6. Increase is peripheral.

Description of holotype. - See Armstrong (1970a).

Discussion. - This species shows intracolony variation similar to that of $S$. ? mclareni (see discussion of $S$.? mclareni). It is distinguished from $S . ?$ mclaren $i$ by its larger corallites and larger number of major septa. Its extreme morphologic variation makes generic placement questionable.

Occurrence.-Lower Carboniferous, Viséan. Peratrovich and Kogruk Formations, Alaska, U.S.A.

\section{Stelechophyllum? niakense (Armstrong)}

Lithostrotionella sp. A. Armstrong, 1970b, p. 25, pl. 7, figs. 1-6. Lithostrotionella sp. B. Armstrong, 1970b, p. 26, pl. 7, figs. 7-9.

Lithostrotionella.niakensis Armstrong, 1972a, p. A23, pl. 4, figs. 2, 6, pl. 9, figs. 1-3, pl. 9, figs. 1-6.

Diagnosis. -Stelechophyllum? with corallite diameter 2.5 to $4.7 \mathrm{~mm}$ and 9 to 14 major septa of variable length that seldom extend from the columella across the tabularium but commonly extend into the dissepimentarium. Minor septa poorly to well developed. Columella absent to poorly developed. Dissepimentarium composed of 1 to 2 rows of mostly large inflated dissepiments. Axial tabulae flat to tent-shaped, spaced 2 in $1 \mathrm{~mm}$. Peripheral tabellae absent to poorly developed. Ratio of tabularium width to corallite diameter about 0.6 . Increase is probably peripheral. 
Description of holotype. - See Armstrong (1972a).

Discussion.-S.? niakense is similar to S.? mclareni but differs in having fewer major septa, more extensions of the major septa into the dissepimentarium, and less polymorphic variation between corallites. S.? niakense differs from S.? macouni in having larger corallites, more major septa, and fewer extensions of the major septa to the columella.

Occurrence.-Lower Carboniferous, Viséan. Kogruk Formation, Alaska, U.S.A.

\section{Stelechophyllum macouni species group \\ Stelechophyllum? macouni (Lambe)}

Lithostrotion macouni Lambe, 1899, p. 220; 1901, p. 176, pl. 14, figs. $11,11 \mathrm{a}, 11 \mathrm{~b}$.

Lithostrotion? macouni Lambe. Nelson, 1960, p. 122, pl. 23, figs. 1, 2 [part].

Lithostrotionella macouni (Lambe). Armstrong, 1970b, p. 23, pl. 12, figs. 1-6.

Diagnosis.-Stelechophyllum? with corallite diameter 1.9 to $2.8 \mathrm{~mm}$ and 9 to 11 major septa that commonly extend from the columella across the tabularium and into the dissepimentarium. Minor septa absent to poorly developed. Columella ordinarily well developed. Dissepimentarium composed of a single row of small inflated dissepiments. Axial tabulae nearly flat to conical, spaced 3 in $1 \mathrm{~mm}$. Peripheral tabellae poorly developed. Ratio of tabularium width to corallite diameter 0.7 . Mode of increase unknown.

Description of lectotype. - GSC 4327 is here designated lectotype for this species. See Nelson (1960) and Armstrong (1970b) for description of this specimen.

Discussion.-This species is distinguished from all other species of Stelechophyllum by its smaller corallite diameter, fewer major septa, and very weakly developed lonsdaleoid dissepimentarium. Its morphology approaches that of Lithostrotion (Lithostrotion), which is unknown in North America

Occurrence. - Lower Carboniferous, Viséan. Prophet Formation, British Columbia, Canada.

\section{Stelechophyllum sp. indet.}

Plate 4, figures 3, 4

Lithostrotionella hemisphaerica Hayasaka, 1936, p. 61 [part].

Discussion.-An indeterminate species of Stelechophyllum is represented by USNM 120239, which is a paratype of Lithostrotionella hemisphaerica Hayasaka. This specimen has corallites 9 to $12 \mathrm{~mm}$ in diameter, 18 to 20 major septa, and an impersistent columella, but the corallites are too badly crushed to permit evaluation of all specific characters.

Occurrence.-Lower Carboniferous, Tournaisian. Madison Limestone, Utah, U.S.A.

Stelechophyllum? sp. indet.

Lithostrotionella sp. Bamber, 1961, p. 129, pl. 10, figs. 2a-d.
Discussion. - Bamber's (1961) specimen has corallites 4 to $8 \mathrm{~mm}$ in diameter, 19 to 21 major septa, a simple columella, and tabulae that appear to be of the Stelechophyllum type. Formal recognition of this species is deferred pending discovery of more specimens.

Occurrence.-Lower Carboniferous, Viséan. Prophet Formation, British Columbia, Canada.

\section{Genus AULOSTYLUS Sando, 1976}

Aulostylus Sando, 1976, p. 427.

Type species. - Lithostrotionella tubifera Hayasaka, 1936, p. 69, pl. 16, figs. 1a, b, 2. Lower Carboniferous (Tournaisian), Montana.

Diagnosis. - See Sando (1976).

Discussion. - This genus was established for lithostrotionelloid corals that have an aulos and a weak columella. Two middle Tournaisian species from the U.S.A. and Canada and a possible representative from the Viséan of China are the only described species. The species formerly referred to Lithostrotionella are listed below; pertinent information on them has been given by Sando (1976).

\section{Aulostylus tubiferus (Hayasaka)}

Lithostrotionella tubifera Hayasaka, 1936, p. 69, pl. 16, figs. 1a, b, 2; Smith and. Yü, 1943, p. 42; Sando, 1963, p. 1076.

Lithostrotion [Lithostrotionella] tubifera (Hayasaka). Bassler, 1950, p. 22,0 .

Aulina tubifera (Hayasaka). Hill, 1940, p. 190; Bamber, 1961, p. 161, pl. 12, figs. 3a-d.

Aulostylus tubiferus (Hayasaka). Sando, 1976, p. 428, figs. 3, 4.

Description of holotype. - See Sando (1976).

Diagnosis. - See Sando (1976).

Discussion. - Sando (1976) recognized two subspecies, A. tubiferus tubiferus and $A$. tubiferus eotubiferus. The holotype of $A$. tubiferus tubiferus is probably from the lower part of the Mission Canyon Limestone in Montana rather than from the Woodhurst Member of the Lodgepole Limestone as stated by Sando (1976).

Aulostylus? sp.

Lithostrotionella sp. A Lo and Chao, 1962, p. 184, pl. 19, fig. 1. Aulostylus? sp. Sando, 1976, p. 431.

\section{Family ACROCYATHIDAE new family}

Diagnosis. - Cerioid and fasciculate colonial Rugosa that have two orders of septa, a columella that ranges from a simple axial plate joined to the counter septum to a complex spiderweb structure made up of axial plate, septal lameliae, and axial tabellae; ordinarily complete conical tabulae; and a lonsdaleoid dissepimentarium.

Type genus. - The type and only included genus is Acrocyathus d'Orbigny, 1849.

Genus ACROCYATHUS d'Orbigny, 1849

Astraea Castelnau, 1843, p. 45 (not Fischer von Waldheim, 1830, pl. 31, fig. 3). 
Acrocyathus d'Orbigny, 1849 a, p. $12 ; 1850$, p. $160 ; 1852$, p. 184; Thevenin in Boule and others, 1906, expl. pl. 6; 1907, p. 90; 1923, p. 90; Easton, 1973, p. 130, 132 [part]; Minato and Kato, 1974, p. 70 [part].

Lithostrotion Fleming. Milne-Edwards and Haime, 1851, p. 433, 483 [part]; Owen, 1852, expl. pl. 4; Hall in Hall and Whitney, 1858, p. 667; Milne-Edwards, 1860, p. 423 [part]; Owen, 1862, p. 364; Rominger, 1876, p. 111; White, 1880a (1883), p. 159 [part]; 1880b, p. 506; 1882, p. 401; Weller, 1898, p. 329 [part]; Ulrich, 1905, p. 33; Butts, 1917, p. 46; 1926, p. 176; 1941, p. 239; Shimer, 1926, p. 27 [part]; Morse, 1930, p. 104; Weller, 1931, p. 274; Kelly, 1942, p. 361 [part]; Allen and Lester, 1954, p. 101.

?Lithostrotion (Lithostrotionella) Yabe and Hayasaka, 1915, p. 133, 1920, p. 11; Bassler, 1950, p. 217, 221.

Lithostrotionella Yabe and Hayasaka. Hayasaka, 1936, p. 58, 61, 62, 65 [part]; Kelly, 1942, p. 352 [part]; Parks, 1951, p. 180; Weller and others, 1952, p. 84; Allen and Lester, 1954, p. 101; Nelson, 1960, p. 117, 118 [part]; 1961, pl. 17 [part]; Yoh, 1961, p. 8; Bamber, 1961, p. 107 [part]; 1966, p. 19 [part]; Armstrong, 1962, p. 39 [part]; 1970a, p. 31 [part]; Wu in Yü and others, 1963, p. 86; Nations, 1963, p. 1257; Minato and Kato, 1974, p. 72 [part].

Lonsdaleia McCoy. Crickmay, 1955, 1961, p. 13.

Eolithostrotionella Zhizhina. Vasilyuk, 1960, p. 95; Zhizhina in Bul'vanker and others, 1960, p. 250, 251, 252; Degtyarev, 1973, p. 192, 193.

Type species.-Acrocyathus floriformis d'Orbigny, 1849 , p. 12 (by monotypy). Lower Carboniferous (Viséan), Indiana, U.S.A.

Diagnosis.-Ordinarily cerioid colonial corals with tabular to hemispherical growth form; one fasciculate species is known and cerioid-fasciculate coralla are rare. Septa of two orders. Major septa thin, seldom extending across tabularium to columella and ordinarily discontinuous or absent in dissepimentarium. Cardinal septum short and situated in a fossula formed by downwarped tabulae in some species. Counter septum commonly long and extending to columella. Minor septa ordinarily absent or poorly developed. Columella ranging from a simple axial plate joined to counter septum to a complex spiderweb structure made up of an axial plate, septal lamellae, and axial tabellae or upturned edges of tabulae. Tabulae ordinarily complete, conical, without well-defined shoulders, but may be nearly horizontal in some species. Peripheral tabellae rare. Dissepimentarium lonsdaleoid, commonly showing traces or crests of discontinuous septa in transverse section. Increase peripheral.

Discussion. - d'Orbigny's (1849a) original proposal and subsequent citations $(1849 \mathrm{~b}, 1852)$ of Acrocyathus provided only brief diagnoses of the genus, and Thevenin's (in Boule, 1906, 1907, 1923) reinvestigation of the type specimen added only illustrations of the exterior of the specimen. Most earlier authors (Milne-Edwards and Haime, 1851, p. 432, 433; 1852, p. 192; Lindstrom, 1883, p. 5, 11; de Koninck, 1872, p. 26; Thevenin, in Boule, 1907, 1923, p. 90; Sanford, 1939, p. 405; Soshkina and others, 1962 , p. 336) regarded Acrocyathus as a junior synonym of Lithostrotion Fleming, although de
Fromentel $(1861,304)$ thought it was a Diphyphyllum Lonsdale, and Wang $(1950$, p. 212) placed it in synonymy with Lonsdaleia McCoy. More recently, some authors (Hill, 1956, p. F307; Ivanovskiy, 1967, p. 34, and Cotton, 1973 , p. 12) linked it questionably with Lithostrotionella Yabe and Hayasaka.

Easton (1973) redescribed in detail the type specimen and illustrated thin sections of it, thus providing the first adequate basis for a determination of the morphology and affinities of the type species. Easton regarded Acrocyathus as a senior synonym of Lithostrotionella and espoused a broad generic concept that included species placed herein in Stelechophyllum Tolmachev and Petalaxis Milne-Edwards and Haime. Minato and Kato (1974, p. 70-71) regarded Acrocyathus as a distinct genus distinguished from Lithostrotionella by having a complex axial structure rather than a simple axial plate.

In my opinion, Acrocyathus is a distinct genus separated from Stelechophyllum and Petalaxis by its complex axial structure and complete conical tabulae. It is distinguished from Lithostrotion by its lonsdaleoid dissepimentarium and complex axial structure and from Lonsdaleia by its lack of a distinct separation of axial and peripheral series of tabellae. Although the morphology of the type species of Lithostrotionella is in doubt, Lithostrotionella is regarded as a probable junior synonym (see p. 4).

Eolithostrotionella is included in the synonymy of Acrocyathus because some of the Russian species were referred to that genus. The type species of Eolithostrotionella is a Stelechophyllum.

Species of Acrocyathus are distinguished on differences in mature corallite diameter, number of major septa at maturity, development of major septa, development of minor septa, complexity of the columella, shape and spacing of the tabulae, size and nurnber of dissepiments, number of rows of dissepiments, and ratio of tabularium width to corallite diameter. Most of the species of Acrocyathus have a cerioid corallum, but one fasciculate species, $A$. proliferus, is included here because of its internal morphologic similarity to cerioid species and the presence of transitional forms. Cerioid species included here are the abundantly represented $A$. floriformis from the Eastern United States; $A$. pilatus from the Mississippi Valley; $A$. girtyi from the Western United States; $A$. pennsylvanicus from western Canada; A. utkae, $A$. rotai, $A$. cystosus, and $A$. lissitzini from the U.S.S.R.; and $A$. hsujiulingi from China. Questionable forms include $A$.? unicus and $A$.? zhizhinae, whose morphology is in doubt, and $A . ?$ shimeri and $A$.? grechovkae, which have essentially horizontal tabulae like Petalaxis but have a complex columella characteristic of Acrocyathus. 
Occurrence.-Lower Carboniferous, lower to upper Viséan. U.S.S.R., U.S.A., Canada, China.

\section{Acrocyathus floriformis d'Orbigny Plates 5-14, 16}

Not Astraea mamillaris Fischer von Waldheim, 1830, pl. 31, fig. 3 Astraea mamillaris Castelnau, 1843, p. 45, pl. 24, fig. 5.

Acrocyathus floriformis d'Orbigny, 1849a, p. 12; 1850, p. 160;1852, p. 184; Thevenin in Boule and others, 1906, expl. pl. 6, pl. 6, figs. 1, 2; 1907 , p. 90 ; 1923, p. 90, expl. pl. 6, pl. 6, figs. 1, 2; Easton, 1973, p. 130, pl. 1, figs. 1a-f.

Acrocyathus sp. Easton, 1973, p. 132, pl. 1, figs. 2a-b.

Not Axinura canadensis Castelnau, 1843, p. 49, pl. 24, fig. 4.

Lithostrotion mamillare Milne-Edwards and Haime, 1851, p. 433, pl. 13, fig. 1 [part]; Hall in Hall and Whitney, 1858, p. 667, pl. 24, figs. $5 \mathrm{a}$, b; Rominger, 1876, p. 111, pl. 55, upper-right figure [part].

Lithostrotion mamillare (Castelnau). White, 1880a (1883), p. 159, pl. 40 , figs. $6 \mathrm{a}$, b; 1880 b, p. 506 , pl. 6 , figs. 1,$2 ; 1882$, p. 401 , pl. 52 , fig. 3.

Not Lithostrotion mamillare(?) Meek, 1864, p. 5, pl. 1, figs. 4-4b.

Lithostrotion canadense Milne-Edwards and Haime, 1851, p. 483, pl. 13, fig. 1 [part]; Milne-Edwards, 1860, p. 423; Owen, 1862, p. 364, fig. 6; Butts, 1926, p. 176, pl. 58, figs. 12, 13; Morse, 1930, p. 104, pl. 9; Weller, 1931, p. 274, pl. 36, figs. 1a, b.

Lithostrotion canadense (Castelnau). Weller, 1898, p. 329 [part]

Lithostrotion? canadense Ulrich, 1905, p. 33, pl. 3, figs. 1, 2

Lithostrotion "canadensis" (Castelnau). Butts, 1941, p. 239, pl. 129, fig. 3.

Lithostrotion basaltiforme Owen, 1852, expl. pl. 4, pl. 4, figs. 5, 6; Butts, 1917, p. 46, pl. 11, figs. 1, 2.

Lithostrotionella castelnaui Hayasaka, 1936, p. 58, pl. 11, figs. 1, 2 [part]; Weller and others, 1952, p. 84, pl. 1, figs. 6, 7; Allen and Lester, 1954, p. 101, pl. 26, fig. 1.

Lithostrotion [Lithostrotionella] castelnaui (Hayasaka). Bassler, 1950, p. 217 [part].

Lithostrotionella americana Hayasaka, 1936, p. 62, pl. 14, figs. 1, 2 [part].

Lithostrotion [Lithostrotionella] americanum Bassler, 1950, p. 217 [part].

Lithostrotionella hemisphaerica Hayasaka, 1936, p. 61, pl. 12, fig. 1, pl. 13, figs. 1, 2 [part]

Lithostrotion [Lithostrotionella] hemisphericum (Hayasaka). Bassler, 1950 , p. 217 [part].

Not Lithostrotionella floriformis Hayasaka, 1936, p. 64, pl. 17, fig. 1.

Material studied.-MNHN 1140 (holotype), FL 411;

USNM 756, 3779, 8211, 13669, 15526, 17071, 17848,

$37466,39654,42695,42766,71646,98102,120235$,

$120236,120237,120238,120240,120241,135092$,

$135094,135096,135097,135172,135173,135174$,

$135177,135179,135300,135301,135302,136704$,

$161989,161990,161991,161992,161993,161994$,

$161995,161997,161998,161999,162000,162001$,

$166604,166605,174376,174377,216198,216199$, $216200,216202,216203,216204,216205,216206$, 216207, 216208, 216210, 216211, 216212, 216214.

Diagnosis. - Predominantly cerioid Acrocyathus with corallite diameter 10 to $30 \mathrm{~mm}$ and 20 to 40 major septa that are ordinarily short and do not extend across the tabularium to the columella and seldom extend into the dissepimentarium. Cardinal fossula ordinarily well developed. Counter septum commonly joined to columella. Minor septa weakly developed as crests on dissepiments. Columella highly variable, ranging from a simple axial plate joined to the counter septum to a complex spiderweb structure made up of an axial plate, septal lamellae, and axial tabellae or upturned edges of tabulae; thysanophylloid variants are known. Dissepimentarium composed of 1 to 5 rows of large and small, ordinarily inflated dissepiments. Tabulae complete, conical, sharply deflected upward at columella and without shoulders or with poorly defined shoulders and spaced about $1 \mathrm{~mm}$ apart. Peripheral tabellae rare. Axial tabellae common. Ratio of tabularium width to corallite diameter 0.4 to 0.6 . Increase is peripheral.

Description of holotype. - See Easton (1973).

Discussion. - This species is characterized by the highly variable structure of the columella and the great range in corallite diameter and number of major septa (fig. 3). The variation in the latter two characters appears to be continuous and does not permit recognition of separate species or subspecies. The species has been divided into two subspecies on the basis of the complexity of the columella (see below). Similarities between Acrocyathus floriformis and the fasciculate species $A$. proliferus are discussed under $A$. proliferus.

Occurrence. $-A$. floriformis is abundant in and characteristic of the St. Louis Limestone and correlative formations in the Southeastern Province of Sando and others $(1975,1977)$. Data on its occurrence are noted under the two subspecies of the species.

\section{Acrocyathus floriformis floniformis d'Orbigny}

Plates 5-11; plate 16, figure 2

Not Astraea mamillaris Fischer von Waldheim, 1830, pl. 31, fig. 3.

Astraea mamillaris Castelnau, 1843, p. 45, pl. 24, fig. 5.

Acrocyathus floriformis d'Orbigny, 1849a, p. 12;1850, p. 160;1852, p. 184; Thevenin in Boule, 1906, expl. pl. 6, pl. 6, figs. 1, 2; 1907, p. 90; 1923 , p. 90 , expl. pl. 6, pl. 6, figs. 1, 2; Easton, 1973, p. 130, pl. 1, figs. 1a-f.

?Lithostrotion mamillare Milne-Edwards and Haime, 1851, p. 433, pl. 13 , fig. 1 [part]; Rominger, 1876 , p. 111, pl. 55, upper right figure [part].

Not Lithostrotion mamillare (Castelnau). White, 1880a (1883), p. 159, pl. 40, figs. $6 \mathrm{a}$, b; 1880b, p. 506, pl. 6, figs. 1, 2; 1882, p. 401, pl. 52, fig. 3 .

Not Lithostrotion mamillare(?) Meek, 1864, p. 5, pl. 1, figs. 4-4b.

?Lithostrotion canadense Milne-Edwards and Haime, 1851, p. 483, pl. 13 , fig. 1 [part].

Lithostrotion canadense Butts, 1926, p. 176, pl. 58, figs. 12, 13

Lithostrotion? canadense Ulrich, 1905, p. 33, pl. 3, figs. 1, 2.

?Lithostrotion basaltiforme Owen, 1852, expl. pl. 4, pl. 4, figs. 5, 6 .

Lithostrotion basaltiforme Owen. Butts, 1917, p. 46, pl. 11, figs. 1, 2. Lithostrotionella castelnaui Hayasaka, 1936, p. 58, pl. 11, figs. 1, 2.

Lithostrotion [Lithostrotionella] castelnaui (Hayasaka). Bassler, 1950, p. 217.

Lithostrotionella americana Hayasaka, 1936, p. 62, pl. 14, figs. 1, 2 [part]. 


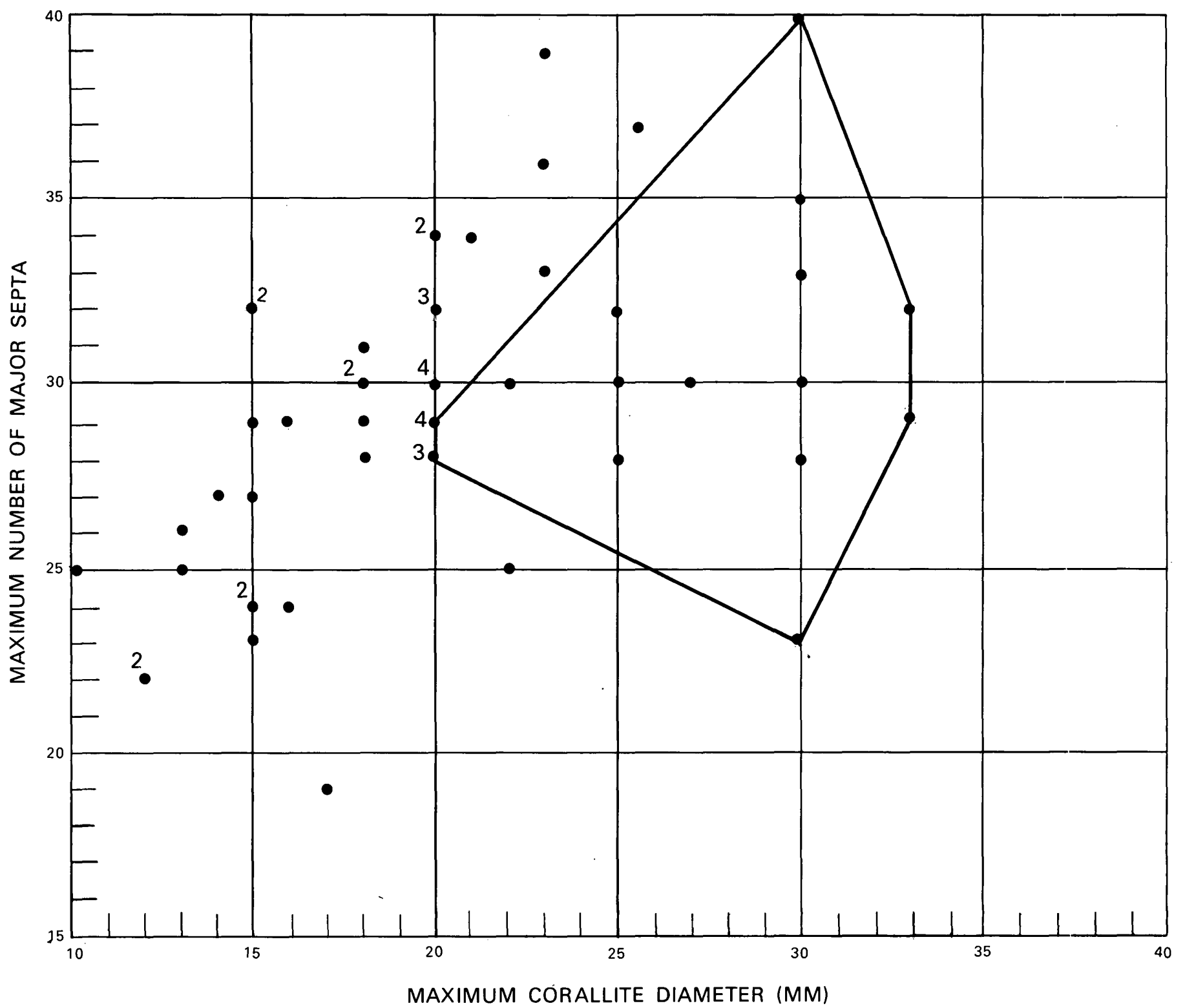

FIGURE 3. - Variation in maximum number of major septa and maximum corallite diameter in 56 coralla of Acrocyathus floriformis. Polygon defines field of variation of coralla from one locality (Livingston, Tenn.). Numbers beside dots indicate more than one corallum.

Lithostrotion [Lithostrotionella] americanum Bassler, 1950, p. 217. Lithostrotionella hemisphaerica Hayasaka, 1936, p. 61, pl. 12, fig. 1, pl. 13, figs. 1, 2 [part].

Lithostrotion [Lithostrotionella] hemisphericum (Hayasaka). Bassler, 1950, p. 217 [part].

Not Lithostrotionella floriformis Hayasaka, 1936, p. 64, pl. 17, fig. 1.

Description of holotype. - See Easton (1973).

Material studied.-MNHN 1140 (holotype), FL 411; USNM 13669, 71646, 120235, 120238, 120240, $120241(?), 161989,161990,161991,161993,161994$, 161995, 161997, 162001(?), 174376, 174377(?), 216205(?), 216206.
Diagnosis. - Acrocyathus floriformis having an axial structure ranging from a simple axial plate to a complex structure composed of an axial plate, a few axial lamellae, and a few concentric intercepts of axial tabellae or upturned edges of axial tabulae in transverse section.

Discussion. - This predominant subspecies of the widespread species $A$. floriformis is distinguished from $A$. floriformis hemisphaericus by its less complex columella. The two subspecies occur in the same formations in the same geographic areas. 
Occurrence.-Lower Carboniferous, middle or upper Viséan. St. Louis Limestone, Indiana, Illinois, Iowa, Kentucky, Missouri, Tennessee, U.S.A.; Greenbrier Limestone and Newman Limestone, Virginia, U.S.A.; Hillsdale Member of Greenbrier Limestone, West Virginia, U.S.A.; Newman Limestone, Kentucky, U.S.A.; Tuscumbia Limestone, Alabama, U.S.A.

Acrocyathus floriformis hemisphaericus (Hayasaka)

Plates 12-14

Lithostrotion mamillare (Castelnau). White, 1880a, p. 159, pl. 40, figs. 1a, b.

Lithostrotion "canadensis" (Castelnau). Butts, 1941, p. 239, pl. 129, fig. 3.

Lithostrotion castelnaui Hayasaka, 1936, p. 58 [part].

Lithostrotion [Lithostrotionella] castelnaui (Hayasaka). Bassler, 1950, p. 217 [part].

Lithostrotionella hemisphaerica Hayasaka, 1936, p. 61, pl. 12, 13, figs. $2 \mathrm{a}, \mathrm{b}$. [part].

Lithostrotion [Lithostrotionella] hemisphericum (Hayasaka). Bassler, 1950 , p. 217.

Material studied.-USNM 8211, 98102, 120236, 120237 (holotype), 161992, 161998, 161999, 162000(?).

Diagnosis. -Acrocyathus floriformis having an axial structure ranging from a simple axial plate to a very complex structure composed of an axial plate, many axial lamellae, and many concentric intercepts of axial tabellae or upturned edges of axial tabulae in transverse section.

Description of holotype. - The specimen is a fragment of a large, silicified, cerioid, hemispherical colony. It is about $15 \mathrm{~cm}$ high and was more than $18 \mathrm{~cm}$ in diameter. Internal structures are poorly preserved.

Corallites are polygonal, have straight double-layered walls as much as $0.25 \mathrm{~mm}$ thick, and range from 10 to 15 $\mathrm{mm}$ in diameter at maturity. Increase is peripheral. The major septa seldom extend to the columella but commonly extend into the dissepimentarium. The cardinal septurn is shorter than the other major septa, and the counter septum commonly joins the columella. There are 26 to 32 major septa at maturity. Minor septa are relatively well developed at the corallite walls and as crests on the dissepiments. The columella ranges from a simple axial plate joined by a few septal lamellae in young corallites to a very complex structure composed of an axial plate, many septal lamellae, and as many as 4 concentric traces of axial tabellae; the columella is as much as $2.5 \mathrm{~mm}$ in diameter. Tabulae are ordinarily complete, conical, curved upward to the columella, and spaced 0.25 to $1 \mathrm{~mm}$ apart. The dissepimentarium is weakly lonsdaleoid and consists of 2 to 3 rows of inflated to flattened dissepiments of varying sizes. There are ordinarily 2 or 3 dissepiments in $1 \mathrm{~mm}$. The ratio of the tabularium width to the corallite diameter is about 0.6 to 0.7. Septal microstructure has been destroyed by silicification.
Discussion. - This subspecies is distinguished by its compact, very complex columella. The holotype (pl. 12, figs. 1,2 ) is a poor example of the species because of the poor preservation of internal structures. A paratype, USNM 161998, is a much better example. This specimen pl. 12, figs. 3,4 ) has as many as 5 tabellar rings around the medial plate. The other paratypes have fewer tabellar rings than USNM 161998, but all have a more complex columella than is found in $A$. floriformis floriformis.

The transverse section of this subspecies mimics that of Lonsdaleia (Actinocyathus) because of its complex columella and lonsdaleoid dissepimentarium. It is readily distinguished from Lonsdaleia (Actinocyathus) in longitudinal section by lacking a distinct continuous separation of axial and peripheral tabellae. The longitudinal section (pl. 12, fig. 3) also shows that the complexity of the columella ranges from a simple structure like that of $A$. floriformis floriformis to a complex structure in the same corallite.

Occurrence.-Lower Carboniferous, middle or upper Viséan. St. Louis Limestone, Illinois, Indiana, and Missouri, U.S.A.; Newman Limestone and Greenbrier Limestone, Virginia, U.S.A.; Hillsdale Mamber of Greenbrier Limestone, West Virginia, U.S.A.

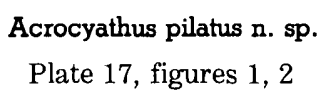

Lithostrotionella girtyi Hayasaka, 1936, p. 65 [part].

Material studied. - USNM 162004 (holotype).

Description of holotype. - The specimen is a fragment of a small, cerioid, hemispherical corallum. It was more than $4.5 \mathrm{~cm}$ high and more than $8 \mathrm{~cm}$ in diameter. The outer part of the specimen is silicified.

Corallites are polygonal, have straight, doublelayered, beaded walls $0.25-0.5 \mathrm{~mm}$ thick, and range from 8 to $11 \mathrm{~mm}$ in diameter at maturity. Increase is peripheral. The major septa most commonly extend to the columella and may or may not extend into the dissepimentarium. The cardinal septum is elongated in some corallites. There are 17 to 19 major septa at maturity. Minor septa are poorly developed as spines on the corallite walls. The columella is complex, composed of a medial plate, septal lamellae, and conical axial tabellae and is as much as $2 \mathrm{~mm}$ in diameter; it is ordinarily thickened by stereoplasm. Tabulae are ordinarily complete, conical, uncurved, and spaced about 0.7 to $0.8 \mathrm{~mm}$ apart. The dissepimentarium is weakly lonsdaleoid and consists of 1 or 2 rows of inflated dissepiments of variable size. There are ordinarily 2 or 3 dissepiments in $1 \mathrm{~mm}$. The ratio of the tabularium width to the corallite diameter is about 0.6 to 0.7 . Septal microstructure is obscured by recrystallization, seemingly diffusotrabecular. 
Discussion.-This species is most similar to Acrocyathus floriformis hemisphaericus by virtue of its complex columella but is distinguished by having fewer tabellar rings and by the stereoplasmic thickening of the columella.

Occurrence.-Lower Carboniferous, middle Viséan. St. Louis Limestone, Illinois, U.S.A.

Acrocyathus proliferus (Hall in Hall and Whitney)

Plate 15; plate 16, figures 1, 3, 4

Lithostrotion mamillare Milne-Edwards and Haime, 1851, p. 433, pl. 13, figs. 1a, b. [part]; Rominger, 1876, p. 111, pl. 55 [part].

Lithostrotion canadense Milne-Edwards and Haime, 1851, p. 483, pl. 13, figs. 1a, b. [part].

Lithostrotion canadense Castelnau. Weller, 1898, p. 329 [part].

Lithostrotion proliferum Hall in Hall and Whitney, 1858, p. 668, pl.24, figs. 6a-c; Rominger, 1876, p. 111, pl. 55; Butts, 1917, p. 45, pl. 10, figs. 15-17; 1926, p. 176, pl. 58, fig. 14; Morse, 1930, p. 102, pl. 8; Weller, 1931, p. 276, pl. 37, figs. 1a, b; Kelly, 1942, p. 361, pl. 51, figs. 1, 4; Allen and Lester, 1954, p. 101, pl. 26, fig. 2; not Davis, 1956 , p. 31, pl. 2, figs. 3a, b.

Lithostrotion? proliferum Hall. Ulrich, 1905, p. 32, pl. 3, figs. 3-7.

Lithostrotionella prolifera (Hall). Butts, 1941, p. 239, pl. 129, figs. 1, 2; Weller and others, 1952, p. 84, pl. 1, fig. 5.

Lithostrotion [Lithostrotionella] proliferum (Hall). Bassler, 1950, p. 217.

Material studied. - USNM 841 (neotype), 4587, 37469, $37470,37471,39655,42667,42705,42714,42845$, 49941, 52681, 60306, 71647, 135085, 135087, 135091, $135095,135098,135168,135176,216201,216207$, 216209, 216213, 239233.

Diagnosis. - Fasciculate Acrocyathus with corallite diameter 10 to $25 \mathrm{~mm}$ and 26 to 49 major septa. Internal morphology like that of Acrocyathus floriformis, but dissepimentarium is consistently weakly lonsdaleoid. Increase is peripheral.

Description of neotype. - I have been unable to locate the specimens originally described and illustrated by Hall (in Hall and Whitney, 1858). I have therefore selected USNM 841, from the St. Louis Limestone, Hardin County, Ill., as neotype for the species.

The neotype is a fragment of a large phaceloid corallum. The specimen is about $12 \mathrm{~mm}$ high and $17 \times 9 \mathrm{~mm}$ in diameter.

Corallites are cylindrical, have single-layered walls about $0.2 \mathrm{~mm}$ thick, and range from 12 to $15 \mathrm{~mm}$ in diameter at maturity. Increase is peripheral. The major septa do not extend to the columella but do extend into the dissepimentarium, most commonly reaching the corallite wall. There are 26 to 29 major septa at maturity. The cardinal septum is slightly shorter than the other major septa and is in a fossula formed by downwarped tabulae. Minor septa are poorly developed as spines on the corallite walls. The columella ranges from a simple axial plate to a structure made up of axial plate, a few axial lamellae, and a few concentric traces of axial tabellae in transverse section. Tabulae are ordinarily complete, conical, curved upward at the columella, and spaced about $1 \mathrm{~mm}$ apart. The dissepimentarium is weakly lonsdaleoid and consists of 1 to 3 rows of inflated dissepiments of variable size. There is ordinarily 1 dissepiment in $2 \mathrm{~mm}$. The ratio of the tabularium width to the corallite diameter is about 0.6 to 0.8 . Septal microstructure is diffusotrabecular.

Discussion. - Colonies of the fasciculate A. proliferus show the same range in variation of internal structures, such as the columella and tabulae, as the cerioid $A$. floriformis. Both forms have a shortened cardinal septum and commonly a long counter septum. The only consistent internal difference is in the dissepimentarium, where the fasciculate forms have fewer rows of dissepiments, and the dissepimentarium is only weakly lonsdaleoid. Increase in both the fasciculate and cerioid forms is peripheral. In the fasciculate forms, the offsets tend to arise in clusters of several new individuals at levels of rejuvenation of the parent corallite.

Form variation was studied in 263 USNM specimens from the St. Louis Limestone and equivalent beds in Alabama, Indiana, Illinois, Iowa, Kentucky, Missouri, Tennessee, Virginia, West Virginia, Georgia, and Michigan. Of these specimens, 154 are cerioid $A$. floriformis and 95 are fasciculate $A$. proliferus. Both forms occur together at two localities. Ordinarily cerioid and fasciculate forms are discrete colonies, but 14 specimens show both growth forms in the same colony (pl. 16). In most of these, cerioid corallites gave rise to fasciculate corallites, but in one colony, a fasciculate form became cerioid at a later stage.

The form variation noted above presents problems in taxonomic treatment of these corals. Some authors (for example, Hill, 1940 , p. 151, 166) place cerioid and fasciculate forms of Lithostrotion and Lonsdaleia in the same genus. Others (for example, Kato, 1966, p. 100-101; Sando, 1975, p. C20) regard the two growth forms as subgenera. The evidence with respect to form variation in "Lithostrotionella" floriformis and "Lithostrotion" proliferum suggests a strong genetic relationship between the two forms. Indeed, the basic similarities in internal structure and the presence of transitional forms might lead to the conclusion that the two forms are merely ecologic variants of the same biologic species. However, the rarity of transitional forms, the lack of detailed information on geographic and stratigraphic distribution of the morphotypes, and the obvious practicality of recognizing the two growth forms as separate entities lead me to maintain them as separate species. The treatment is different from my treatment of Lithostrotion and Lonsdaleia, because in North America, Lithostrotion is represented almost entirely by the fasciculate form (Siphonodendron), and fasciculate and cerioid Lonsdaleia are separated from 
each other in different faunal provinces. Furthermore, no transitional forms are known between the subgenera of either Lithostrotion or Lonsdaleia in North America.

Occurrence. - Lower Carboniferous, middle or upper Viséan. St. Louis Limestone and equivalent strata, Illinois, Georgia, Kentucky, Tennessee, Alabama, and Michigan, U.S.A.

\section{Acrocyathus girtyi (Hayasaka)}

Plate 17, figures 3,4

Lithostrotionella girtyi Hayasaka, 1936, p. 65, pl. 13, figs. 3a, b.

?Lithostrotionella sp. Parks, 1951, p. 180, pl. 29, figs. 2a, b.

Material studied. - USNM 120243 (holotype).

Description of holotype. - The specimen is a fragment of a large hemispherical corallum. It was more than 15 $\mathrm{cm}$ in diameter and attained a height of more than $8 \mathrm{~cm}$. The outer part of the specimen is silicified.

Corallites are polygonal, have straight double-layered walls as much as $0.3 \mathrm{~mm}$ thick, and range from 8 to 11 $\mathrm{mm}$ in diameter at maturity. Increase is peripheral. Except for the counter septum, the major septa are short and do not extend to the columella and seldom extend into the dissepimentarium. There are 18 to 21 major septa at maturity. Minor septa are absent or poorly developed. The columella is a simple axial plate connected to the counter septum in young corallites but is composed of an axial plate, septal lamellae, and upturned edges of tabulae in mature corallites. The columella is ordinarily thickened by stereoplasm and attains a maximum diameter of $2 \mathrm{~mm}$. Tabulae are ordinarily complete, conical, turned up at the columella, and spaced 0.5 to $1 \mathrm{~mm}$ apart. The dissepimentarium is strongly lonsdaleoid and consists of a single row of large inflated dissepiments. There are ordinarily 1 or 2 dissepiments in $2 \mathrm{~mm}$. The ratio of the tabularium width to the corallite diameter is about 0.6 to 0.7. Septal microstructure is fibronormal.

Discussion. - This species has a columella and corallite diameter like that of $A$. pilatus but is distinguished from the latter by its strongly lonsdaleoid dissepimentarium, single row of dissepiments, and septa that seldom extend to the columella. The specimen illustrated by Parks (1951) from the "Brazer Limestone" in Utah may belong here, but the lack of information on morphological details prevents certain identification.

Occurrence. - Lower Carboniferous, middle or upper Viséan. Little Flat Formation, Utah, U.S.A.

\section{Acrocyathus pennsylvanicus (Shimer)}

Lithostrotion pennsylvanicum Shimer, 1926, p. 27, pl. 5, figs. 3-5 [part].

Lithostrotionella pennsylvanica (Shimer). Kelly, 1942, p. 352, pl. 50, figs. 1, 2, 5, 6, 8; Bamber, 1961, p. 145, pl. 11, figs. 1b, c, 3a-f; 1966 , p. 19, pl. 4, figs. 1a-c, 2a-c.

Lithostrotion [Lithostrotionella] pennsylvanicum (Shimer). Bassler, 1950, p. 221.
Lonsdaleia pennsylvanica (Shimer). Crickmay, 1955, 1961, p. 13, pl. 1, figs. 11, 12.

Lithostrotionella pennsylvanicum (Shimer). Nelson, 1960, p. 117, pl. 22, figs. 4-6; 1961, pl. 17, figs. 3, 4.

Diagnosis. -Cerioid Acrocyathus with corallite diameter 10 to $17 \mathrm{~mm}$ and 18 to 23 major septa that ordinarily approach the columella but do not reach it and seldom extend into the dissepimentarium. Minor septa weakly developed. Columella complex, composed of an axial plate, septal lamellae, and axial tabellae or upturned edges of tabulae. Dissepimentarium composed of 1 to 3 rows of large and small inflated dissepiments. Tabulae complete, conical, sharply deflected upward at columella, without shoulders or with poorly defined shoulders, and spaced about $0.5 \mathrm{~mm}$ apart. Ratio of tabularium width to corallite diameter 0.5 to 0.8 . Mode of increase unknown.

Description of lectotype.-See Nelson (1960) and Bamber: (1966).

Discussion.-This species falls within the range of Acrocyathus floriformis on corallite diameter and number of major septa. A. pennsylvanicus is distinguished from $A$. floriformis by lacking differentiation of the cardinal and counter septa, by having fewer rows of dissepiments, and by its larger ratio of tabularium width to corallite diameter.

Occurrence.-Lower Carboniferous, middle or upper Viséan. Mount Head Formation, Alberta, Canada; Prophet Formation, British Columbia, Canada.

\section{Acrocyathus utkae (Degtyarev)}

Eolithostrotionella utkae Degtyarev, 1973, p. 192, pl. 1, figs. 1a, b.

Diagnosis.-Cerioid Acrocyathus with corallite diameter 1 to $15 \mathrm{~mm}$ and 22 to 25 major septa that approach the columella but ordinarily do not reach it and seldom extend into the dissepimentarium. Minor septa absent. Columella composed of a thickened axial plate commonly joined by counter and cardinal septa, septal lamellae, and concentric traces of upturned tabulae in transverse section. Dissepimentarium composed of 1 to 3 rows of large inflated dissepiments. Tabulae complete, conical to nearly horizontal, and spaced about $0.5 \mathrm{~mm}$ apart. Ratio of tabularium width to corallite diameter about 0.6. Mode of increase unknown.

Description of holotype. - See Degtyarev 1973).

Discussion. - This species is similar to A.? grechovkae but differs in having larger corallites, more major septa, a more complex columella, and conical tabulae.

Occurrence.-Lower Carboniferous, lower or middle Viséan. Zapadnouralsk Horizon, Ural Mountains, U.S.S.R.

Acrocyathus rotai (Zhizhina in Bul'vanker and others)

Eolithostrotionella rotai Zhizhina in Bul'vanker and others, 1960, p. 251 , pl. 61, figs. $2 a$, b. 
Diagnosis.-Cerioid Acrocyathus with corallite diameter 15 to $20 \mathrm{~mm}$ and 22 to 26 major septa that commonly reach the columella but seldom extend into the dissepimentarium. Minor septa absent or poorly developed. Columella seemingly simple to complex. Dissepimentarium composed of 1 to 3 rows of mostly large inflated dissepiments. Tabulae complete, conical, and spaced about $0.5 \mathrm{~mm}$ apart. Ratio of tabularium width to corallite diameter about 0.6 . Mode of increase unknown.

Description of holotype. - See Zhizhina (in Bul'vanker and others, 1960).

Discussion. - At first glance, the transverse section of this species suggests Stelechophyllum, but the tabulae are clearly of the Acrocyathus type, and the axial structures in some corallites appear to be complex.

Occurrence.-Lower Carboniferous, middle or upper Viséan. Zone $\mathrm{C}_{1} \mathrm{v}$, Donetz Basin, U.S.S.R.

Acrocyathus cystosus (Zhizhina in Bul'vanker and others)

Eolithostrotionella cystosa Zhizhina in Bul'vanker and others, 1960, p. 250, pl. 61, figs. 1a, b.

Diagnosis.-Cerioid Acrocyathus with corallite diameter 20 to $30 \mathrm{~mm}$ and 28 to 38 major septa that may or may not extend to the columella and seldom extend into the dissepimentarium. Minor septa poorly developed. Columella seemingly simple to complex. Dissepimentarium composed of as many as 5 rows of dissepiments of varying sizes. Tabulae complete, conical, and spaced about $0.5 \mathrm{~mm}$ apart. Ratio of tabularium width to corallite diameter about 0.4 to 0.5 . Mode of increase unknown.

Description of holotype. - See Zhizhina (in Bul'vanker and others, 1960).

Discussion. - This species is distinguished by its broad dissepimentarium.

Occurrence.-Lower Carboniferous, lower to upper Viséan. Zones $\mathrm{C}_{1}{ }^{\mathrm{v} b}$ to $\mathrm{C}_{1}$ ff, Donetz Basin, U.S.S.R.

$$
\begin{gathered}
\text { Acrocyathus lissitzini (Zhizhina in Bul'vanker and } \\
\text { others) }
\end{gathered}
$$

Eolithostrotionella lissitzini Zhizhina in Bul'vanker and others, 1960, p. 252 , pl. 61 , figs. $3 \mathrm{a}$, b.

Diagnosis.-Cerioid Acrocyathus with corallite diameter 15 to $20 \mathrm{~mm}$ and 18 to 25 major septa that approach the columella but seldom reach it and seldom extend into the dissepimentarium. Minor septa absent. Columella seemingly simple to complex. Dissepimentarium composed of 1 to 3 rows of dissepiments of varying sizes. Tabulae complete, conical, and spaced about 1 $\mathrm{mm}$ apart. Ratio of tabularium width to corallite diameter about 0.4 to 0.5 . Mode of increase unknown.

Description of holotype. - See Zhizhina (in Bul'vanker and others, 1960).
Occurrence.-Lower Carboniferous, middle or upper Viséan. Zone $\mathrm{C}_{1} \mathrm{vf}$, Donetz Basin, U.S.S.R.

Acrocyathus hsujiulingi (Yoh)

Lithostrotionella hsujiulingi Yoh, 1961, p. 8, 16, pl. 13, figs. 1a-c.

Diagnosis.-Cerioid Acrocyathus with corallite diameter averaging $6 \mathrm{~mm}$ and about 16 major septa that approach the columella but seldom reach it and do not extend into the dissepimentarium. Minor septa well developed. Columella composed of a thickeried axial plate joined to the counter septum, septal lamellae, and concentric traces of tabulae in transverse section. Dissepimentarium composed of a single row of dissepiments of varying sizes. Tabulae complete, conical, and spaced about $0.5 \mathrm{~mm}$ apart. Ratio of tabularium width to corallite diameter about 0.5 . Mode of increase seemingly peripheral.

Description of holotype. - See Yoh (1961).

Discussion.-This species differs from the other Chinese species, $A$.? unicus, in having fewer major septa, fewer rows of dissepiments, and a somewhat more complex columella.

Occurrence. - Lower Carboniferous(?), Kwangsi Province, China.

Acrocyathus? unicus (Yabe and Hayasaka)

Lithostrotion (Lithostrotionella) unicum Yabe and Hayasaka, 1915, p. 133; 1920, p. 11, pl. 9, figs. 12a, b.

Lithostrotionella unica Yabe and Hayasaka. Wu in Yü and others, 1963, p. 86, pl. 24, figs. 7a, b.

Lithostrotionella unicum Yabe and Hayasaka. Minato and Kato, 1974, p. 72 , pl. 15, fig. 1 .

Diagnosis.-Cerioid Acrocyathus? with corallite diameter averaging $7 \mathrm{~mm}$ and about 22 to 26 major septa that approach the columella but seldom reach it and seldom extend into the dissepimentarium. Minor septa well developed. Columella seemingly a simple axial plate augmented by a few axial tabellae and septal lamellae. Dissepimentarium composed of 1 to 3 rows of large inflated dissepiments. Tabulae complete, conical, and spaced 6 to 7 in $2 \mathrm{~mm}$. Ratio of tabularium width to corallite diameter about 0.5 . Mode of increase unknown.

Description of holotype.-See Yabe and Hayasaka $(1915,1920)$ and Minato and Kato (1974).

Discussion.-This species, the type of Lithostrotionella, is referred to Acrocyathus with query because of uncertainty concerning the morphology of the type specimen (see previous discussion on page 4).

Occurrence.-Carboniferous(?), Yun-nan Province, China.

\section{Acrocyathus? shimeri (Crickmay)}

Lithostrotion pennsylvanicum Shimer, 1926, p. 27 [part]. Lonsdaleia shimeri Crickmay, 1955, 1961, p. 13, pl. 1, figs. 9, 10. 
Lithostrotionella shimeri (Crickmay). Nelson, 1960, p. 114, pl. 21, figs. 9-15, pl. 22, figs. 1-3; 1961, pl. 14, figs. 3-5, pl. 16, figs. 8, 9, pl. 17, fig. 5, pl. 18, figs. 4, 5; Bamber, 1961, p. 137, pl. 10, figs. 4a-d, pl. 11, figs. 1a, d-j, 2a-d; Armstrong, 1962, p. 39, pl. 3, figs. 13-15, text-fig. 19.

Lithostrotionella pennsylvanica (Shimer). Armstrong, 1970a, p. 31, pl. 9, figs. 1-3.

Diagnosis.-Cerioid Acrocyathus? with corallite diameter 7 to $13 \mathrm{~mm}$ and 17 to 30 major septa that commonly extend across the tabularium to the columella and seldom extend into the tabularium. Minor septa ordinarily well developed. Columella complex, composed of an axial plate, septal lamellae, and the upturned edges of tabulae. Dissepimentarium composed of a single row of inflated dissepiments. Tabulae complete, essentially horizontal, but deflected upward at columella, and spaced about $0.75 \mathrm{~mm}$ apart. Ratio of tabularium width to corallite diameter about 0.4 to 0.5 . Increase is peripheral.

Description of holotype. - See Nelson (1960).

Discussion. - This species is distinguished by its nearly horizontal tabulae, which approach the morphology of Petalaxis. It differs from the species of Petalaxis by its complex columella.

Occurrence. - Lower Carboniferous, middle and upper Viséan. Mount Head.Formation, Alberta and British Columbia, Canada; Peratrovich Formation, Alaska, U.S.A.; Black Prince Limestone, Arizona, U.S.A.

\section{Acrocyathus? grechovkae (Degtyarev)}

Eolithostrotionella grechovkae Degtyarev, 1973, p. 193, pl. 1, fig. 2, pl. 2, figs. 1a, $b$.

Diagnosis.-Cerioid Acrocyathus? with corallite diameter 10 to $12 \mathrm{~mm}$ and 18 to 24 major septa that approach the columella but seldom reach it and seldom extend into the dissepimentarium. Minor septa absent. Columella ordinarily a simple thickened axial plate surrounded by intersections of upturned tabulae in transverse section and occasionally abutted by a few septal lamellae. Dissepimentarium composed of 2 to 3 rows of large inflated dissepiments. Tabulae complete, nearly horizontal at the periphery, but deflected upward at the columella, and spaced about $0.5 \mathrm{~mm}$ apart. Ratio of tabularium width to corallite diameter about 0.6. Mode of increase unknown.

Description of holotype. - See Degtyarev (1973).

Discussion.-This species is similar to A.? shimeri in having nearly horizontal tabulae but differs in having fewer major septa, no minor septa, more rows of dissepiments, and a less complex columella.

Occurrence.-Lower Carboniferous, lower or middle Viséan. Zapadnouralsk Horizon, Ural Mountains, U.S.S.R.

\section{Acrocyathus? zhizhinae (Vasilyuk)}

Eolithostrotionella zhizhinae Vasilyuk, 1960, p. 95, pl. 25, figs. 1, 1 a.
Diagnosis.-Cerioid-fasciculate Acrocyathus? with corallite diameter 13 to $20 \mathrm{~mm}$ and 25 to 27 major septa that extend to the columella but do not extend into the dissepimentarium. Minor septa well developed, contratingent. Columella seemingly simple to complex, absent in some corallites. Dissipimentarium composed of 1 to 4 rows of dissepiments of varying sizes. Tabulae complete, flat to conical, and spaced 0.75 to $1 \mathrm{~mm}$ apart. Ratio of tabularium width to corallite diameter about 0.5 . Mode of increase unknown.

Description of type material. - See Vasilyuk (1960).

Discussion. - The original description and illustrations of this species leave some doubt concerning the structure of the columella and the tabulae. The species is therefore referred to Acrocyathus with a query. The long contratingent minor septa are noteworthy.

Occurrence.-Lower Carboniferous, lower to middle Viséan. Zones $\mathrm{C}_{1} \mathrm{v}^{\mathrm{c}}$ and $\mathrm{C}_{1}{ }^{\mathrm{v}} \mathrm{d}$, Donetz Basin, U.S.S.R.

Acrocyathus spp. indet.

The following taxa are not adequately described and illustrated for specific identification:

Lithostrotionella americana Hayasaka(?). Nelson, 1960, p. 1.18, pl. 23, fig. 3. Lower Carboniferous, Viséan. Mount Head Formation, Alberta, Canada.

Lithostrotionella shimeri (Crickmay). Nations, 1963, p. 1257, pl. 176, figs. 1, 2. Base of Black Prince Limestone in pebble derived from Escabrosa Limestone, Arizona, U.S.A.

\section{Family PETALAXIDAE Fomichev, 1953}

\section{Genus PETALAXIS Milne-Edwards and Haime, 1852}

Stylaxis Milne-Edwards and Haime, 1851, p. 452 [part] (not McCoy, 1849, p. 119).

Petalaxis Milne-Edwards and Haime, 1852, p. 204 [part]; MilneEdwards, 1860, p. 440 [part]; not Barrois, 1882, p. 305; Roemer, 1883 , p. 387, 388 [part]; Lindstrom, 1883, p. 12; Stuckenberg, 1888 , p. 20 [part]; 1895 , p. 74 [part]; Yanishevskiy, 1900, p. 89[?]; Etheridge, 1900, p. 17; Grosch, 1909, p. 5; Yabe and Hayasaka, 1915, p. 94 (32); Bolkhovitinova, 1915, p. 63[?]; Gabounia, 1919, p. 39[?]; not Chi, 1931, p. 28; Dobrolyubova, 1935b, p. 10; Heritsch, 1939, p. 18; not Hill, 1940, p. 165; not Lang, Smith, and Thomas, 1940 , p. 97; Kolosvary, 1951, p. 39[?]; Fomichev, 1953, p. 449; not Hill, 1956, p. F 282; Soshkina, Dobrolyubova, and Kabakovich, 1962, p. 339; de Groot, 1963, p. 81; Onoprienko, 1970, p. 3; Fedorowski and Gorianov, 1973, p. 58; not Minato and Kato, 1974, p. 68; Kozyreva, 1974, p. 24 [part]; Sutherland, 1977, p. 185.

Lithostrotion Fleming. Eichwald, 1861, p. 149; Trautschold, 1879, p. 36 [part]; Bassler, .1950 , p. 222 [part].

Lithostrotion (Petalaxis) Fomichev, 1931, p. 43.

Lithostrotion (Lithostrotionella) Merriam, 1942, p. 377 [part]; Bassler, 1950, p. 220, 222, 235, 252; Easton, 1960, p. 578.

Lithostrotionella Yabe and Hayasaka. Chi, 1931, p. 28; Yü, 1933 [1934], p. 102[?]; Dobrolyubova, 1935a, p. 10; 1935b, p. 10, 12; 1936a, p. 28; Hayasaka, 1936, p. 65, 70 [part]; Heritsch, 1937, p. 164; Fomichev, 1939, p. 60; Minato, 1955, p. 99[?]; Yokoyama, 1957, p. 78; Nelson, 1960, p. 114 [part]; Yamagiwa, 1961, p. 102[?]; Bamber, 1961, p. 107 [part]; de Groot, 1963, p. 80 [part]; Wu in Yü 
and others, 1963, p. 86[?]; Minato and Kato, 1974, p. 68; Onoprienko, 1976, p. 29 [part].

Lithostrotionella (Hillia) de Groot, 1963, p. 86.

Lonsdaleia McCoy. Dobrolyubova, 1935a, p. 12; 1935b, p. 29.

Cystolonsdaleia Fomichev, 1953, p. 464 [part].

Eastonoides Wilson and Langenheim, 1962, p. 511.

Type species. -Stylaxis M'coyana Milne-Edwards and Haime, 1851 , p. 453 , pl. 12, figs. 5, 5a, equals Petalaxis M'coyana Milne-Edwards and Haime, 1852, p. 205, equals Petalaxis maccoyanus Milne-Edwards and Haime (by subsequent designation of Roemer, 1883, p. 387, 388). Middle Carboniferous (Moscovian), Moscow Basin, U.S.S.R.

Diagnosis.-Cerioid colonial corals with tabular to hemispherical growth form. Septa of two orders. Major septa thin, ordinarily extending into the tabularium but seldom reaching the columella and ordinarily discontinuous or absent in the dissepimentarium, but species with weakly lonsdaleoid dissepimentarium are known. Minor septa absent to well developed. Columella ordinarily a simple axial plate joined to counter and (or) cardinal septum but composed of axial plate, impersistent vertical axial tabellae, and a few axial lamellae in some species. Tabulae complete and incomplete, essentially horizontal, flat, concave, or convex, turned up at columella in some species. Peripheral clinotabellae may be present. Dissepimentarium ordinarily lonsdaleoid but may be mostly regular in some species. Increase peripheral and intermural.

Discussion. - Milne-Edwards and Haime (1852, p. 204) proposed Petalaxis for corals previously described and named Stylaxis M'coyana and Stylaxis portlocki (Milne Edwards and Haime, 1851, p. 452) because Stylaxis had become a junior synonym of Lithostrotion, and these two species were distinct. $P$. M'coyana, described and illustrated in 1851, was distinguished by having septa that were interrupted by the dissepiments and did not reach the corallite wall. The type specimen was collected by Verneuil at Kolomna on the Oka River in the Moscow Basin, U.S.S.R., where it is now known that beds of Middle Carboniferous (Moscovian) age are exposed. Subsequently, Hill (1940, p. 167) determined that $P$. portlocki, from the Lower Carboniferous of England, is a Lithostrotion. Milne-Edwards (1860, p. 440) diagnosed the genus Petalaxis for the first time, basing the diagnosis on the previous description of $P$. M'coyana.

Lang, Smith, and Thomas (1940, p. 97) concluded incorrectly that Petalaxis is a replacement name for Nematophyllum and that, therefore, Petalaxis is a junior synonym of Lithostrotion. Hill (1940, p. 167) also attempted to place Petalaxis in the synonymy of Lithostrotion by selecting $P$. portlocki as type species. However, the foregoing nomenclatural actions were invalidated by Roemer's $(1883$, p. 387, 388) earlier designation of $P$. M'coyana as the type species of Petalaxis.
Although the name Petalaxis was used by several earlier Russian authors (Stuckenberg, 1888, 1895; Yanishevskiy, 1900, Bolkhovitinova, 1915; Gabounia, 1919, Fomichev, 1931), there was confusion over the meaning of the name for many years. In the meanwhile, Yabe and Hayasaka (1915) had proposed Lithostrotionella, and some authors (for example, Dobrolyubova, 1935a, b, 1936a) used this name in preference to Petalaxis for corals with a simple columella and lonsdaleoid dissepiments, regardless of the nature of the tabulae. Fomichev (1953, p. 449-463) sought to clarify the usage of Petalaxis by regarding $P$. maccoyanus as the type species and describing some other Middle Carboniferous corals under the name of Petalaxis; he noted that forms with horizontal tabulae are characteristic of the Middle Carboniferous in contrast to the tent-shaped tabulae of Early Carboniferous corals.

Kozyreva (1974, p. 24-26) summarized the history of Petalaxis and stressed the importance of horizontal tabulae in the definition of the genus. She included in the genus some North American species that actually belong to Stelechophyllum, Acrocyathis, and Thysanophyllum.

Sutherland (1977) reviewed the Petalaxis problem and pointed out that the type specimen has been lost. He based his discussion of the genus on a study of topotypes at the Paleontological Institute in Moscow. Sutherland called attention to the fact that the topotypes have a variable axial structure that is complex in some corallites. He also stressed the horizontal tabulae as a distinguishing feature of Petalaxis, which occurs predominantly in the Middle Carboniferous.

Petalaxis is distinguished from Acrocyatihus and Stelechophyllum chiefly by its horizontal tabulae and by its columella. In Acrocyathus, the tabulae are conical, without well-defined shoulders, and in Stelecho'phyllum, the tabulae are tent-shaped, with well-defined shoulders and a peripheral zone of more or less horizontal tabellae. In Petalaxis, the columella is most commonly a simple, thickened or unthickened axial plate connected to the counter and (or) cardinal septum, but some species have impersistent vertical axial tabellae and rare septal lamellae. In Acrocyathus, the columella ranges from a simple axial plate to a complex spiderweb structure composed of axial plate, septal lamellae, and axial tabellae or upturned tabulae. In Stelechophyllum, the colvmella is always a simple axial plate or rod unmodified by axial tabellae or septal lamellae.

Fomichev (1953, p. 464) proposed Cystolonsdaleia as a subgenus of Petalaxis for corals from the Middle and Upper Carboniferous of the Donetz Basin that have a columella composed of a medial plate, a few septal lamellae, and axial tabellae similar to the Early Carboniferous Lonsdaleia. The type species of 
Cystolonsdaleia is C. lutugini Fomichev from the Moscovian of the Donetz Basin. Fomichev also included Lonsdaleia portlocki (Stuckenberg) of Dobrolyubova (1935a, b) and Lonsdaleia ivanovi Dobrolyubova (1935a, b) from the Moscovian of the Moscow Basin and indicated that species attributed to Stylidophyllum from the Permian of China by Yoh and Huang (1932) and Huang (1932) might belong to the new subgenus. The Permian species were later reassigned to genera of the Family Waagenophyllidae by Minato and Kato (1965).

Petalaxis maccoyanus, the type species of Petalaxis, has an impersistently developed complex axial structure with the same morphologic elements as the axial structure of most of the Moscovian species assigned to Cystolonsdaleia by Fomichev. It seems impractical to separate these species generically from $P$. maccoyanus. The type species of Cystolonsdaleia, $C$. lutugini, differs from the other Moscovian species by having a complex spiderweb columella with inner zone of tabellae distinct from an outer zone of regular concave tabulae. Accordingly, Cystolonsdaleia is retained as a separate genus for this complex species, whereas the other species are placed in Petalaxis.

De Groot (1964, p. 86) proposed Hillia as a subgenus of Lithostrotionella for corals from the Bashkirian of Spain that differ from Lithostrotion by having major septa that fall short of the columella, horizontal tabulae, and a columella connected to the cardinal septum; they differ from true Lithostrotionella by having a poorly developed lonsdaleoid dissepimentarium.

In other corals that have a columella arising from a single septum, that septum is the counter septum wherever the septa can be identified. De Groot gave no evidence for her conclusion that the septum in Hillia is the cardinal septum, and her illustrations of species assigned to Hillia show no basis for that conclusion. The columella appears to be the same as that seen in many species of Petalaxis. Moreover, the name Hillia is preoccupied by Hillia Grote (1883) and Hillia Mallock (1929), according to Cotton (1974, p. 13), and a replacement name has not been proposed. In my opinion, the reasons for separating Hillia de Groot from Petalaxis are insufficient, and I am reassigning the species of Hillia to Petalaxis, recognizing them only as a species group within that genus.

Eastonoides was proposed by Wilson and Langenheim (1962, p. 511) for a Permian coral that has a columella composed of an axial plate connected to the counter septum augmented by rare axial tabellae, slightly sloping tabulae, and a vertically discontinuous lonsdaleoid dissepimentarium. Lonsdaleia ivanovi Dobrolyubova was included as the only other known species referred to Eastonoides. The essential features of this genus are so similar to the type species of Petalaxis that I regard
Eastonoides as a junior synonym of Petalaxis, which includes four other Permian species.

Species of Petalaxis are distinguished on differences in mature corallite diameter, number of major septa at maturity, development of minor septa, complexity and development of the columella, major septal extensions into the tabularium, major septal extensions into the dissepirnentarium, shape and completeness of the tabulae, spacing of the tabulae, number of rows of dissepiments, size and shape of the dissepiments, and the ratio of tabularium width to corallite diameter.

The species of Petalaxis may be arranged in five species groups:

1. P. simplex group, including simplex, wyomingensis, tabulatus, bailliei, and tschucoticus. This group comprises simple forms having mostly complete tabulae turned up at the columella and a simple columella; these forms occur in the Lower Carboniferous (Viséan) and lowest Middle Carboniferous (Namurian).

2. P. flexuosus group, including flexuosus, donbassicus, mokomokensis, exiguus, brokawi, monocyclicus, sexangulus, taishakuensis, immanis, belinskiensis, major, fomichevi, and grootae. This group comprises forms having a simple columella and a narrow dissepimentarium (large ratio of tabularium width to corallite diameter); these forms occur in the Middle Carboniferous (Bashkirian and Moscovian) and Permian.

3. P. wagneri group, including wagneri, perapertuensis, radians, intermedius, santaemariae, cantabricus, orboensis, and occidentalis. This group comprises forms having a simple columella and a weakly lonsdaleoid dissepimentarium; these forms occur in the Middle Carboniferous (Bashkirian and Moscovian) and Permian.

4. $P$. vesiculosus group, including vesiculosus, lisitschanskensis, exilis, confertus, persubtilis, korkhovae, mirus, and evidens. This group comprises forms having a simple columella and a narrow dissepimentarium (small ratio of tabularium width to corallite diameter); these forms occur in the Middle Carboniferous (Bashkirian and Moscovian).

5. P. maccoyanus group, including maccoyanus, stylaxis, mohikanus, celadensis, elyensis, dobrolyubovae, donetsensis, and ivanovi. This group comprises forms having a complex columella; these forms occur in the Middle Carboniferous (Moscovian) and Permian.

Occurrence.-Lower Carboniferous (Viséan), Middle Carboniferous (Namurian, Bashkirian, and Moscovian), and Permian. U.S.S.R., U.S.A., Canada, Spain, Japan, China(?), Spitzbergen(?). 
Petalaxis simplex species group

Petalaxis simplex (Hayasaka)

Plate 18, figures 1-3

Lithostrotionella simplex Hayasaka, 1936, p. 70, pl. 14, figs. 4a, b; Bamber, 1961, p. 155, pl. 12, figs. 2a-c.

Lithostrotion [Lithostrotionella] simplex (Hayasaka). Bassler, 1950, p. 220.

Material studied. - USNM 120249 (holotype).

Description of holotype. - The specimen is a fragment of a corallum of indeterminate shape in limestone matrix. It was more than $9 \mathrm{~cm}$ in diameter and more than $4 \mathrm{~cm}$ in height.

Corallites are polygonal, have straight, slightly beaded, double-layered walls as much as $0.3 \mathrm{~mm}$ thick, and range from 6 to $9 \mathrm{~mm}$ in diameter at maturity. Except for the counter septum, the major septa are short, do not extend to the columella, and seldom extend into the dissepimentarium. There are 16 to 18 major septa at maturity. Minor septa are absent or poorly developed. The columella is a simple thin axial plate that may or may not be connected to the counter septum. Tabulae are ordinarily complete and essentially horizontal; some are turned up at the columella to produce concentric traces in the transverse sections of some corallites. Tabulae are irregularly spaced 0.5 to $1 \mathrm{~mm}$ apart. The dissepimentarium is strongly lonsdaleoid and consists of a single row of large inflated dissepiments. There are ordinarily about 2 dissepiments in $2 \mathrm{~mm}$. The ratio of the tabularium width to the corallite diameter is about 0.6 to 0.7. The mode of increase is indeterminate. Septal microstructure is fibronormal.

Discussion.-Comparison with $P$. wyomingensis is made under the discussion of that species.

Occurrence.-Lower Carboniferous, upper Viséan. Little Flat Formation, Utah, U.S.A.

Petalaxis wyomingensis, n. sp.

Plate 18, figures 4,5

Lithostrotionella simplex Hayasaka, 1936, p. 70 [part].

Material studied. - USNM 120675 (holotype).

Description of holotype. - The specimen is a fragment of a corallum of indeterminate shape in limestone matrix. It was more than $7 \mathrm{~cm}$ in diameter and more than $4 \mathrm{~cm}$ in height.

Corallites are polygonal, have sinuous, beaded, double-layered walls as much as $0.6 \mathrm{~mm}$ thick, and range from 7 to $9 \mathrm{~mm}$ in diameter at maturity. The major septa ordinarily extend to the columella but seldom extend into the dissepimentarium. There are 17 to 18 major septa at maturity. Minor septa are absent. The columella is a simple thickened axial plate ordinarily connected to the counter septum. It is as much as $0.7 \mathrm{~mm}$ in short diameter and $1 \mathrm{~mm}$ in long diameter. Tabulae are complete or incomplete, essentially horizontal, turned up at the columella, and irregularly spaced 0.25 to $0.5 \mathrm{~mm}$ apart. The dissepimentarium is strongly lonsdaleoid and consists of 1 to 3 rows of inflated dissepiments of varying sizes. Ordinarily, there are 1 to 3 dissepiments in 2 $\mathrm{mm}$. The ratio of tabularium width to the corallite diameter is about 0.5 to 0.6 . The mode of increase is indeterminate. Septal microstructure is fibronormal.

Discussion.-The holotype of this species was a paratype of Lithostrotionella simplex Hayasaka. $P$. wyomingensis is similar to $P$. simplex (Hayasaka) but differs in having longer major septa, a thickened columella, thicker corallite walls, more rows of dissepiments, a smaller ratio of tabularium width to corallite diameter, and more tabulae.

Occurrence.-Middle Carboniferous, Namurian. "Wells" Formation, Wyoming, U.S.A.

Petalaxis tabulatus (Hayasaka)

Plate 19, figures 5-7

Lithostrotionella tabulata Hayasaka, 1936, p. 69, pl. 17, fig. 2.

Lithostrotion [Lithostrotionella] tabulatum (Hayasaka). Bassler, 1950 p. 220.

Material studied.-USNM 120246 (holotype), USNM 216197 (paratypes).

Description of holotype. - The specimen is a fragment of a corallum of indeterminate shape. It was more than $12 \mathrm{~cm}$ in diameter and $14 \mathrm{~cm}$ in height.

Corallites are polygonal, have straight, beaded, and denticulate double-layered walls as much as $0.4 \mathrm{~mm}$ thick, and range from 8 to $10 \mathrm{~mm}$ in diameter at maturity. The major septa ordinarily extend to the columella and into the dissepimentarium. There are 16 to 18 major septa at maturity. Minor septa are ordinarily well developed. The columella is a simple, serrated, thickened axial plate connected to one or more major septa. Tabulae are mostly complete, essentially horizontal, commonly turned up at the columella, and irregularly spaced 0.25 to $0.5 \mathrm{~mm}$ apart. The dissepimentarium is composed of 1 to 2 rows of inflated dissepiments of varying sizes. There are 2 to 4 dissepiments in $2 \mathrm{~mm}$. The ratio of tabularium width to corallite diameter is about 0.6 to 0.7 . The mode of increase is peripheral. Septal microstructure is obscure, seemingly amorphous.

Discussion. - The transverse section of this species looks like that of a Stelechophyllum. It is placed in Petalaxis because of its horizontal tabulae. The species differs from $P$. wyomingensis in having a serrated, less thickened columella, to which more major septa are attached, thinner corallite walls, a larger ratio of tabularium width to corallite diameter, more extensions of the major septa into the tabularium, and welldeveloped minor septa.

Occurrence.- Lower Carboniferous, upper Viséan. Aspen Range Formation, Idaho, U.S.A. 
Petalaxis bailliei (Nelson)

Lithostrotionella bailliei Nelson, 1960, p. 114, pl. 21, figs. 7, 8; 1962, pl. 14, figs. 1, 2.

Lithostrotionella cf. bailliei Nelson. Bamber, 1961, p. 126, pl. 10, figs. 1a-g.

Diagnosis.-Petalaxis with corallites 5 to $6 \mathrm{~mm}$ in diameter and 17 to 18 major septa that ordinarily extend to the columella but seldom extend into the dissepimentarium. Minor septa ordinarily well developed. Columella a simple thickened axial rod or plate formed by extension of the counter septum. Dissepimentarium composed of a single row of large inflated dissepiments. Tabulae ordinarily complete, essentially horizontal, and irregularly spaced 3 in $1 \mathrm{~mm}$. Ratio of tabularium width to corallite diameter about 0.5. Mode of increase unknown.

Description of holotype. - See Nelson (1960).

Discussion. - This species is distinguished from $P$. wyomingensis and $P$. tabulatus by its smaller corallite diameter.

Occurrence.-Lower Carboniferous, Viséan. Mount Head Formation, Alberta, Canada; and Prophet Formation, British Columbia, Canada (E. W. Bamber, written commun., 1980).

\section{Petalaxis tschucoticus (Onoprienko)}

Lithostrotionella tschucotica Onoprienko, 1976, p. 30, pl. 10, fig. 6, pl. 11 , figs. $1,2$.

Diagnosis. - Petalaxis with corallite diameter 5 to 7 $\mathrm{mm}$ and 15 to 17 major septa that ordinarily extend to the columella but seldom extend into the dissepimentarium. Minor septa poorly developed. Columella a simple axial plate connected to cardinal and counter septa. Dissepimentarium composed of a single row of large inflated dissepiments. Tabulae ordinarily complete, horizontal, commonly turned up at columella, regularly spaced 0.3 to $0.5 \mathrm{~mm}$ apart. Ratio of tabularium width to corallite diameter about 0.5 to 0.6 . Mode of increase unknown.

Description of type material. - See Onoprienko (1976).

Discussion.-This species differs from $P$. bailliei by having fewer major septa, a less robust columella, and weaker minor septa.

Occurrence.-Lower Carboniferous, Namurian. Yunon Suite, West Chukotka, U.S.S.R.

\section{Petalaxis flexuosus species group}

Petalaxis flexuosus (Trautschold)

Lithostrotion flexuosum Trautschold, 1879, p. 37, pl. 5, figs. 7a, b.

Lithostrotionella flexuosa (Trautschold). Dobrolyubova, 1935a, p. 11, pl. 3, figs. 1, 2; 1935b, p. 18, pl. 3, figs. 1, 2 .

?Lithostrotionella flexuosa (Trautschold). Heritsch, 1939, p. 30, pl. 13, fig. 5 , pl. 19 , fig. 5 .

?Lithostrotion [Lithostrotionella] flexuosum Trautschold. Bassler, 1950, p. 235.
Diagnosis. - Petalaxis with corallite diameter 5 to 7 $\mathrm{mm}$ and 14 to 17 major septa that approach the columella but seldom reach it and commonly extend into the dissepimentarium. Minor septa well developed. Columella a simple thickened axial plate ordinarily connected to the counter septum and to the cardinal septum in some corallites. Dissepimentarium composed of 1 to 2 rows of generally small inflated dissepiments of varying sizes. Tabulae complete and incomplete, horizontal to inclined, flat, concave or convex, irregularly spaced 0.25 to $1 \mathrm{~mm}$ apart. Ratio of tabularium width to corallite diameter 0.6 to 0.7 . Mode of increase unknown.

Description of type material. - See Trautschold (1879). The diagnosis is taken largely from Dobrolyubova's (1935b) descriptions and illustrations of topotypes.

Discussion.-Petalaxis flexuosus differs from $P$. stylaxis by lacking a complex columella and by having better development of the minor septa, more extensions of the major septa into the dissepimentarium, and generally smaller dissepiments.

Fomichev (1953, p. 453) and Kozyreva (1974, p. 25) placed $P$. flexuosus in the synonymy of $P$. maccoyanus Milne-Edwards and Haime because of general similarity in morphology. I regard these two species as distinct because $P$. flexuosus does not seem to have axial tabellae like $P$. maccoyanus. However, Sutherland (1977, p. 187) pointed out that the complexity of the axial structure is a variable feature in topotypes of $P$. maccoyanus; hence, Dobrolyubova's (1935b) description may be based on simple corallites in a variable colony.

Heritsch's (1939) specimen is referred questionably to the species because no longitudinal section is available.

Occurrence.-Middle Carboniferous, Moscovian. Myachkovo Horizon $\left(\mathrm{C}_{2}{ }^{4}\right)$, Moscow Basin, U.S.S.R. Kings Bay, Spitzbergen(?).

\section{Petalaxis donbassicus (Fomichev)}

Lithostrotionella donbassica Fomichev, 1939, p. 60, pl. 9, figs. 4a, b. Lithostrotion [Lithostrotionella] donbassica (Fomichev). Bassler, 1950 , p. 222.

Diagnosis.-Petalaxis with corallite diameter 5 to 7 $\mathrm{mm}$ and 14 to 17 major septa that approach the columella but seldom reach it and commonly extend into the dissepimentarium. Minor septa well developed. Columella a strongly thickened axial plate ordinarily connected to the counter septum. Dissepimentarium composed of 1 to 2 rows of inflated dissepiments of varying sizes. Tabulae ordinarily complete, horizontal, irregularly spaced 0.25 to $0.5 \mathrm{~mm}$ apart. Ratio of tabularium width to corallite diameter 0.5 to 0.6 . Mode of increase unknown.

Description of type material. - See Fomichev (1939).

Discussion.-This species is very similar to Petalaxis flexuosus, from which it differs in having better develop- 
ment of the minor septa, a thicker columella, a wider dissepimentarium (smaller ratio of tabularium width to corallite diameter), and more complete tabulae.

Occurrence. - Middle Carboniferous, Moscovian. Svita $\mathrm{C}_{2}{ }^{6}\left(\mathrm{~L}_{5}\right)$, Donetz Basin, U.S.S.R.

Petalaxis mokomokensis (Easton)

Lithostrotion [Lithostrotionella] mokomokensis Easton, 1960, p. 578, text-figs. 9, 10.

Diagnosis. - Petalaxis with corallite diameter about 7 $\mathrm{mm}$ and 15 major septa that ordinarily are short and do not extend to the columella or into the dissepimentarium. Minor septa poorly developed. Columella a thin axial plate connected to the counter septum. Dissepimentarium composed of 1 to 2 rows of large inflated dissepiments. Tabulae complete and incomplete, essentially horizontal, mostly concave, irregularly spaced 0.25 to $0.75 \mathrm{~mm}$ apart. Ratio of tabularium width to corallite diameter about 0.7. Mode of increase unknown.

Description of type material. - See' Easton (1960).

Discussion. - This species is distinguished from Middle Carboniferous species from the Soviet Union by its thinner columella and more generally concave tabulae.

Occurrence.-Permian. Arcturus Formation, Nevada, U.S.A.

\section{Petalaxis exiguus n. sp.}

Plate 19, figures 1-4

Lithostrotionella girtyi Hayasaka, 1936, p. 65 [part].

Lithostrotion [Lithostrotionella] girtyi (Hayasaka). Bassler, 1950, p. 220 [part].

Material studied.-USNM 162002B (holotype) and USNM 162002A (paratype).

Description of holotype. - The specimen is a small complete silicified corallum $3.5 \mathrm{~cm}$ in diameter and $2 \mathrm{~cm}$ in height.

Corallites are polygonal, have straight to rounded, beaded, sinuous, double-layered walls as much as 0.4 $\mathrm{mm}$ thick, and range from 10 to $12 \mathrm{~mm}$ in diameter at maturity. Except for the counter and cardinal septa, the major septa extend about halfway to the columella and are present in the dissepimentarium only as crests. There are 14 to 15 major septa at maturity. Minor septa are absent. The columella is a simple thickened axial plate, commonly connected to both counter and cardinal septa. Tabulae are complete or incomplete, essentially horizontal, concave to convex, and irregularly spaced 0.5 to $1 \mathrm{~mm}$ apart. The dissepimentarium is strongly lonsdaleoid and consists of 1 to 2 rows of mostly large inflated dissepiments. The ratio of tabularium width to corallite diameter is about 0.6. Increase is peripheral. Septal microstructure is fibronormal.

Discussion. - The holotype and paratype of this new species were paratypes of Lithostrotionella girtyi
Hayasaka. The two type specimens are so small that they may actually represent immature coralla, although no larger coralla were found at the type locality. The description of the holotype serves as a diagnosis for the species, because the paratype is essentially identical with the holotype.

Petalaxis exiguus is distinguished from $P$. mokomokensis, another Permian form, by its diminutive corallum, thickened columella, larger corallite diameter, and smaller ratio of tabularium width to corallite diameter.

Occurrence.-Permian. McCloud Limestone, California, U.S.A.

\section{Petalaxis brokawi (Wilson and Langenheim)}

Lithostrotionella sp. Langenheim and others, 1960, p. 151.

Lithostrotionella brokawi Wilson and Langenheim, 1962, p. 512, pl. 88, figs. $7,8$.

Diagnosis. - Petalaxis with corallite diameter 4 to 5 $\mathrm{mm}$ and 10 to 15 major septa that ordinarily are short and do not extend to the columella and seldom extend into the dissepimentarium. Minor septa ordinarily well developed. Columella a simple thickened axial plate ordinarily connected to the counter septum. Dissepimentarium composed of 1 to 2 rows of mostly large inflated dissepiments. Tabulae mostly complete, inclined slightly toward columella, and irregularly spaced 0.25 to $0.5 \mathrm{~mm}$ apart. Ratio of tabularium width to corallite diameter about 0:5. Mode of increase unknown.

Description of type specimens.-See Wilson and Langenheim (1962).

Discussion.-Petalaxis brokawi is distinguished from $P$. mokomokensis by its smaller corallites, thickened columella, well-developed minor septa, and smaller ratio of tabularium width to corallite diameter.

Occurrence.-Lower Permian. Ely Limestone, Nevada, U.S.A.

Petalaxis monocyclicus (de Groot)

Lithostrotionella monocyclica de Groot, 1963, p. 85, pl. 17, figs. 1a-c.

Diagnosis.-Petalaxis with corallite diameter 5 to 8 $\mathrm{mm}$ and 20 to 24 major septa that ordinarily approach the columella but do not reach it and seldom extend into the dissepimentarium. Minor septa absent. Columella a simple thin axial plate connected to the counter septum and to the cardinal septum in some corallites. Dissepimentarium composed of 1 to 3 rows of elongate dissepiments of varying sizes. Tabulae complete, essentially horizontal, concave, turned up at the columella, and irregularly spaced 0.25 to $1 \mathrm{~mm}$ apart. Ratio of tabularium width to corallite diameter about 0.4 to 0.5 . Mode of increase peripheral.

Description of holotype. - See de Groot (1964 [1963]).

Discussion. - This species differs from the Middle Carboniferous and Permian species diagnosed on previous pages in this report by having tabulae that are regularly 
concave and turned up at the columella. It also has more major septa.

Occurrence.-Middle Carboniferous, Bashkirian. Santa Maria Limestone, Palencia, Spain.

\section{Petalaxis sexangulus (de Groot)}

Lithostrotionella sexangulus de Groot, 1963, p. 84, pl. 16, figs. 3a-c, $4 \mathrm{a}, \mathrm{b}$.

Diagnosis. -Petalaxis with corallite diameter 3 to 4 $\mathrm{mm}$ and 13 to 15 major septa that ordinarily extend about halfway to the columella and seldom extend into the dissepimentarium. Minor septa poorly developed. Columella a simple slightly thickened axial plate connected to the counter septum and to the cardinal septum in some corallites. Dissepimentarium composed of a single row of small dissepiments. Tabulae mostly complete, essentially horizontal, but commonly nearly tentshaped, turned up at the columella, and irregularly spaced 0.25 to $1 \mathrm{~mm}$ apart. Ratio of tabularium width to corallite diameter about 0.8. Mode of increase unknown.

Description of type material.-See de Groot (1964 [1963]).

Discussion. - This species is distinguished from other members of the $P$. flexuosus species group by its very large ratio of tabularium width to corallite diameter and its tabulae that are commonly nearly tent-shaped and turned up at the columella.

Occurrence.-Middle Carboniferous, Moscovian. Palencia, Spain.

Petalaxis taishakuensis (Yokoyama)

Lithostrotionella taishakuensis Yokoyama, 1957, p. 78, pl. 10, figs. 1-4.

Diagnosis.-Petalaxis with corallite diameter 3 to 4 $\mathrm{mm}$ and 13 to 15 major septa that ordinarily are short and do not extend to the columella and seldom extend into the dissepimentarium. Minor septa well developed. Columella a simple axial plate connected to the counter septum and joined by 2 or 3 other major septa. Dissepimentarium composed of 1 to 2 rows of inflated dissepiments of varying sizes. Tabulae complete and incomplete, essentially horizontal, and irregularly spaced 0.25 to $1 \mathrm{~mm}$ apart. Ratio of tabularium width to corallite diameter about 0.6 to 0.7 . Mode of increase unknown.

Description of holotype. - See Yokoyama (1957).

Discussion. - This species is distinguished from $P$. sexangulus by having its columella joined by several major septa, by having stronger major septa, by its tabulae not being turned up at the columella, by its smaller ratio of tabularium width to corallite diameter, and by having more rows of dissepiments.

Occurrence.-Middle Carboniferous. Dangyokei Formation, Hiroshima, Japan.
Petalaxis immanis Kozyreva

Petalaxis immanis Kozyreva, 1974, p. 30, pl. 2, figs. 4a-c, 5a, b.

Diagnosis.-Petalaxis with corallite diameter 8 to 18 $\mathrm{mm}$ and 17 to 18 major septa that ordinarily approach the columella but do not reach it and seldom extend into the dissepimentarium. Minor septa absent or poorly developed. Columella a simple, strongly thickened axial plate connected to counter septum. Dissepimentarium composed of 2 rows of small inflated dissepiments. Tabulae complete, essentially horizontal, turned up at columella, and irregularly spaced 0.25 to $0.5 \mathrm{~mm}$ apart. Ratio of tabularium width to corallite diameter about 0.5 to 0.6. Mode of increase unknown.

Description of type material. - See Kozyreva (1974).

Discussion.-This species is distinguished from all other members of the $P$. flexuosus species group by its very large corallites and its strongly thickened columella.

Occurrence.-Middle Carboniferous, Bashkirian. Horizon $b_{1}-b_{2}$, Voronezh anteclise, U.S.S.R.

\section{Petalaxis belinskiensis Fomichev}

Petalaxis mccoyana var. belinskiensis Fomichev, 1953, p. 457, pl. 31, figs. $3 a, b$.

Diagnosis. - Petalaxis with corallite diameter 7 to 12 $\mathrm{mm}$ and 16 to 24 major septa that approach the columella but seldom reach it and commonly extend into the dissepimentarium. Minor septa well developed. Columella a simple thickened axial plate ordinarily connected to the counter septum. Dissepimentarium composed of 1 to 3 rows of inflated dissepiments of varying sizes. Tabulae mostly complete, essentially horizontal, and spaced 0.25 to $0.5 \mathrm{~mm}$ apart. Ratio of tabularium width to corallite diameter about 0.4 to 0.5 . Mode of increase unknown.

Description of type material. - See Fomichev (1953).

Discussion.-This species is distinguished from $P$. donbassicus by having larger corallites, more major septa, and a broader dissepimentarium. It lacks the complex columella that characterizes $P$. mccoyana.

Occurrence.-Middle Carboniferous, Moscovian. $\mathrm{L}_{5}$ Limestone, Donetz Basin, U.S.S.R.

Petalaxis major (de Groot)

Lithostrotionella maccoyana forma major de Groot, 1963, p. 83, pl. 16, figs. $2 \mathrm{a}, \mathrm{b}$.

Diagnosis.-Petalaxis with corallite diameter 5 to 9 $\mathrm{mm}$ and 17 to 22 major septa that closely approach the columella but seldom reach it and that commonly extend into the dissepimentarium. Minor septa well developed. Columella a simple axial plate, seldom dilated, connected to the counter septum. A few septal lamellae present in some corallites but no axial tabellae. Dissepimentarium composed of 1 to 3 rows of inflated 
dissepiments of varying sizes. Tabulae mostly incomplete, horizontal, concave, and irregularly spaced 0.25 to $0.5 \mathrm{~mm}$ apart. Ratio of tabularium width to corallite diameter about 0.6 . Increase peripheral.

Description of holotype. - See de Groot (1964 [1963]). The holotype is RGM 112726.

Discussion.-This species differs from $P$. mccoyanus by lacking a complex columella and by its larger corallite diameter and more numerous major septa. It differs from $P$. vesiculosus by having longer major septa, more major septa, by the presence of septal lamellae, and by having more rows of dissepiments.

Occurrence.-Middle Carboniferous, Moscovian. Vañes Formation, Palencia, Spain.

\section{Petalaxis fomichevi n. sp.}

Petalaxis maccoyana Milne-Edwards and Haime. Fomichev, 1953, p. 453, pl. 31, figs. 1a-d, 2a-d.

Diagnosis.-Petalaxis with corallite diameter 5 to 8 $\mathrm{mm}$ and 13 to 22 major septa that extend about half way to the columella and commonly extend into the dissepimentarium. Minor septa well developed. Columella a simple thickened axial plate ordinarily connected to the counter septum and to the cardinal septum in some corallites. Dissepimentarium composed of 1 to 3 rows of inflated dissepiments of varying sizes. Tabulae complete and incomplete, flat to convex, horizontal, and spaced 0.25 to $0.5 \mathrm{~mm}$ apart. Ratio of tabularium width to corallite diameter about 0.5 to 0.7 . Mode of increase unknown.

Description of type material.-See Fomichev (1953). The holotype is here designated specimen number 57 of Fomichev (1953, p. 456).

Discussion. - This species differs from P. maccoyanus by lacking a complex columella and other morphological details. It is distinguished from $P$. flexuosus by having more major septa, more regular tabulae, and more rows of dissepiments.

Occurrence.-Middle Carboniferous, Moscovian. $\mathrm{L}_{5}$ Limestone, Donetz Basin, U.S.S.R.

\section{Petalaxis grootae, n. sp.}

Lithostrotionella maccoyana (Edwards and Haime). De Groot, 1963, p. 82 , pl. 16, fig. 1a, b.

Diagnosis.-Petalaxis with corallite diameter 4 to 6 $\mathrm{mm}$ and 14 to 16 major septa that approach the columella but seldom reach it and seldom extend into the dissepimentarium. Minor septa well developed. Columella a simple axial plate, curved in some corallites, and ordinarily connected to the counter septum. Dissepimentarium composed of 1 to 3 rows of inflated dissepiments of varying sizes. Tabulae complete and incomplete, essentially horizontal, flat, concave or convex, and spaced 0.25 to $0.75 \mathrm{~mm}$ apart. Ratio of tabularium width to corallite diameter about 0.6 to 0.7 . Mode of increase unknown.

Description of type material. - See de Groot (1964 [1963], p. 83): The holotype is here designated RGM 112721.

Discussion. - This species differs from $P$. maccoyanus by lacking a complex columella. It is distinguished from $P$. flexuosus by having longer major septa, a thinner, commonly curved columella, more rows of dissepiments, and more regularly spaced tabulae.

Occurrence.-Middle Carboniferous, Moscovian. Vañes Formation and Cotarraso Limestone, Palencia, Spain.

Petalaxis wagneri species group

Petalaxis wagneri (de Groot)

Lithostrotionella (Hillia) wagneri de Groot, 1963, p. 88, pl. 18, figs. 1-3.

Diagnosis.-Petalaxis with corallite diameter 3 to 4.5 $\mathrm{mm}$ and 14 to 16 major septa that closely approach the columella but seldom reach it and extend into the dissepimentarium, ordinarily being attached to the corallite wall. Minor septa ordinarily well developed. Columella a simple axial plate connected to counter or cardinal septum. Dissepimentarium weakly lonsdaleoid, composed of a single row of small inflated dissepiments. Tabulae complete or incomplete, essentially horizontal, mostly concave, and spaced 0.5 to $1 \mathrm{~mm}$ apart. Ratio of tabularium width to corallite diameter about 0.7 to 0.8 . Increase peripheral.

Description of type material. - See de Groot (1964 [1963]).

Discussion. - This species is similar to $P$. maccoyanus but has smaller corallites, fewer major septa, a weakly lonsdaleoid dissepimentarium, and a simple columella.

Occurrence.-Middle Carboniferous, Bashkirian. Perapertú Formation, Palencia, Spain.

$$
\text { Petalaxis perapertuensis (de Groot) }
$$

Lithostrotionella (Hillia) perapertuensis de Groot, 1963, p. 89, pl. 19, figs. 1a-c, 2a-d.

Diagnosis.-Petalaxis with corallite diameter 3.5 to $4.5 \mathrm{~mm}$ and 14 to 19 major septa that closely approach the columella but seldom reach it and ordinarily extend across the dissepimentarium to the corallite wall. Minor septa ordinarily well developed. Corallite walls strongly dilated. Columella a simple thickened axial plate connected to counter or cardinal septum. Dissepimentarium weakly lonsdaleoid, composed of 1 to 2 rows of small inflated dissepiments. Tabulae incomplete, essentially horizontal, mostly concave, and spaced 0.25 to $0.5 \mathrm{~mm}$ apart. Ratio of tabularium width to corallite diameter 0.6 to 0.8 . Increase peripheral.

Description of type material.-See de Groot (1964 [1963]). 
Discussion. - This species differs from $P$. wagneri by having more major septa, more tabulae, and strongly dilated corallite walls.

Occurrence.-Middle Carboniferous, Bashkirian. Perapertú Formation, Palencia, Spain.

\section{Petalaxis radians (de Groot)}

Lithostrotionella (Hillia) radians de Groot, 1963, p. 89, pl. 20, figs. $1 \mathrm{a}-\mathrm{c}$.

Diagnosis.-Petalaxis with corallite diameter 7 to 9 $\mathrm{mm}$ and 15 to 18 major septa that closely approach the columella but seldom reach it and extend into the dissepimentarium, ordinarily being attached to the corallite wall. Minor septa ordinarily well developed. Columella a simple axial plate connected to the counter or cardinal septum. Dissepimentarium weakly lonsdaleoid, composed of 1 to 3 rows of inflated dissepiments of varying sizes. Tabulae incomplete, horizontal, mostly convex, and irregularly spaced 0.25 to $1 \mathrm{~mm}$ apart. Ratio of tabularium width to corallite diameter about 0.5 to 0.6 . Mode of increase unknown.

Description of type material.-See de Groot (1964 [1963]).

Discussion. - This species differs from $P$. wagneri by having larger corallites, more rows of dissepiments, and less regular tabulae.

Occurrence.-Middle Carboniferous, Bashkirian. Perapertú Formation, Palencia, Spain.

Petalaxis intermedius (de Groot)

Lithostrotionella (Hillia) intermedia de Groot, 1963, p. 90, pl. 20, figs. $2 \mathrm{a}, \mathrm{b}, 3$.

Diagnosis.-Petalaxis with corallite diameter 5 to 7 $\mathrm{mm}$ and 16 to 19 major septa that closely approach the columella but seldom reach it and extend into the dissepimentarium, commonly being attached to the corallite wall. Minor septa well developed. Columella a simple axial plate connected to counter or cardinal septum. Dissepimentarium weakly lonsdaleoid, composed of 1 to 4 rows of mostly small inflated dissepiments. Tabulae mostly incomplete, flat, concave or convex, horizontal, and irregularly spaced 0.25 to $0.75 \mathrm{~mm}$ apart. Ratio of tabularium width to corallite diameter about 0.7 to 0.8 . Increase peripheral.

Description of type material. -See de Groot (1964 [1963]).

Discussion. - This species differs from $P$. wagneri by having larger corallites, more major septa, and more tabulae.

Occurrence.-Middle Carboniferous, Bashkirian. Perapertú Formation, Palencia, Spain.

Petalaxis santaemariae (de Groot)

Lithostrotionella (Hillia) santaemariae de Groot, 1963, p. 91, pl. 21, figs. 1a-e.
Diagnosis. -Petalaxis with corallite diameter 3.5 to 8 $\mathrm{mm}$ and 16 to 19 major septa that closely approach the columella but seldom reach it and extend into the dissepimentarium, ordinarily attached to the corallite wall. Minor septa poorly developed. Corallite walls strongly dilated. Columella a simple thickened axial plate connected to counter or cardinal septum. Dissepimentarium weakly lonsdaleoid, composed of a single row of small inflated dissepiments. Tabulae mostly complete, horizontal, mostly concave, and irregularly spaced 0.25 to $1 \mathrm{~mm}$ apart. A peripheral zone of clinotabellae may be present. Ratio of tabularium width to corallite diameter about 0.8 . Increase peripheral.

Description of holotype. - See de Groot (1964 [1963]).

Discussion. - This species differs from P. perapertuensis by having larger corallites, poorly developed minor septa, and fewer tabulae.

Occurrence. - Middle Carboniferous, Bashkirian. Santa Maria Limestone, Palencia, Spain.

\section{Petalaxis cantabricus (de Groot)}

Lithostrotionella (Hillia) cantabrica de Groot, 1963, p. 92, pl. 22, figs. 1-4.

Diagnosis.-Petalaxis with corallite diameter 4 to 8 $\mathrm{mm}$ and 19 to 28 major septa that closely approach the columella but seldom reach it and extend into the dissepimentarium, ordinarily being attached to the corallite wall. Minor septa well developed. Corallite wall strongly dilated and denticulate. Columella a simple commonly thickened axial plate connected to counter or cardinal septum. Dissepimentarium weakly lonsdaleoid, composed of 1 to 3 rows of small inflated dissepiments. Tabulae mostly complete, horizontal, concave, and spaced 0.25 to $1 \mathrm{~mm}$ apart. A peripheral zone of clinotabellae may be present. Ratio of tabularium width to corallite diameter about 0.6 to 0.7 . Increase peripheral.

Description of type material. -See de Groot (1964 [1963]).

Discussion. -This species is distinguished from all others in the $P$. wagneri species group by having more major septa.

Occurrence.-Middle Carboniferous, Bashkirian to Moscovian(?). Santa Maria Limestone, Perapertú Formation, and Celada Limestone, Palencia, Spain.

$$
\text { Petalaxis orboensis (de Groot) }
$$

Lithostrotionella orboensis de Groot, 1963, p. 85, pl. 17, figs. 2a-d.

Diagnosis. -Petalaxis with corallite diameter 4.5 to 8 $\mathrm{mm}$ and 16 to 21 major septa that closely approach the columella but seldom reach it and extend into the dissepimentarium, commonly being attached to the corallite wall. Minor septa well developed. Columella a simple axial plate connected to counter or cardinal septum; 
columella absent or discontinuous in some corallites. Dissepimentarium weakly lonsdaleoid, composed of 1 to 3 rows of inflated dissepiments of varying sizes. Tabulae complete and incomplete, generally horizontal but turned up at columella, and spaced 0.25 to $0.5 \mathrm{~mm}$ apart. Ratio of tabularium width to corallite diameter about 0.7. Mode of increase unknown.

Description of type material. -See de Groot (1964 [1963]).

Discussion. - This species is distinguished from others in the $P$. wagneri group by having tabulae that are turned up at the columella and by having the columella absent or discontinuous in some corallites.

Occurrence. - Middle Carboniferous, Moscovian. Orbo Limestone, Palencia, Spain.

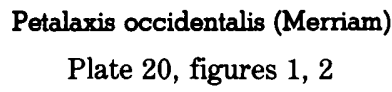

Lithostrotion (Lithostrotionella) occidentalis Merriam, 1942, p. 377, pl. 56, figs. 2, 4, 7, 8, 11.

Lithostrotion [Lithostrotionella] occidentale Merriam. Bassler, 1950, p. 252.

Diagnosis.-Petalaxis with corallite diameter 4.5 to $6.5 \mathrm{~mm}$ and 16 to 19 major septa that closely approach the columella but seldom reach it and extend into the dissepimentarium, commonly being attached to the corallite wall. Minor septa well developed. Corallite wall dilated and denticulate. Columella a simple thickened axial plate connected to the counter or cardinal septum. Dissepimentarium weakly lonsdaleoid, composed of 1 to 2 rows of small inflated dissepiments Tabularium consists of a peripheral zone of clinotabellae and a periaxial zone of mostly complete, horizontal, flat or concave tabulae spaced 0.25 to $0.75 \mathrm{~mm}$ apart. Ratio of tabularium width to corallite diameter about 0.6 . Mode of increase unknown.

Description of holotype.-See Merriam (1942). The holotype is USNM 143440; new thin sections of this specimen are illustrated herein for clarification of morphologic details.

Discussion. - This species differs from P. perapertuensis by having larger corallites, a thicker columella, and well-developed clinotabellae.

Occurrence. - Permian. Coyote Butte Formation, Oregon, U.S.A.

\section{Petalaxis vesiculosus species group}

Petalaxis vesiculosus (Dobrolyubova)

Lithostrotionella vesiculosa Dobrolyubova, 1935a, p. 11, pl. 2, figs. 3, 4; 1935b, p. 19, pl. 2, figs. 3, 4.

Lithostrotion [Lithostrotionella] vesiculosa Dobrolyubova. Bassler, 1950, p. 222.

Diagnosis. -Petalaxis with corallite diameter 6 to 12 $\mathrm{mm}$ and 10 to 14 major septa that may or may not extend to the columella and seldom extend into the dissepimentarium. Minor septa ordinarily well developed. Columella a simple thickened axial plate ordinarily connected to the counter and cardinal septa. Dissepimentarium composed of 2 to 6 rows of inflated dissepiments of varying sizes. Tabulae complete or incomplete, horizontal, concave or convex, and irregularly spaced 0.25 to $1 \mathrm{~mm}$ apart. Ratio of tabularium width to corallite diameter about 0.3 to 0.4 . Mode of increase peripheral.

Description of holotype. - See Dobrolyubova (1935b).

Discussion.-This species is distinguished from all species of the $P$. flexuosus and $P$. wagneri groups by its broader dissepimentarium.

Occurrence.-Middle Carboniferous, Moscovian. Myachkovo Horizon $\left(\mathrm{C}_{2}{ }^{4}\right)$, Moscow Basin, U.S.S.R.

\section{Petalaxis lisitschanskensis Fomichev}

Petalaxis vesiculosa (Dobrolyubova) var. lisitschanskensis Fomichev, 1953 , p. 462 , pl. 32 , figs. $3 \mathrm{a}$, b.

Diagnosis. -Petalaxis with corallite diameter 12 to 15 $\mathrm{mm}$ and 16 to 21 major septa that approach the columella and may or may not reach it and do not extend into the dissepimentarium. Minor septa ordinarily well developed. Columella a simple thickened axial plate ordinarily connected to the counter septum. Dissepimentarium composed of 1 to 5 rows of inflated dissepiments of variable size. Tabulae complete or incomplete, horizontal, concave or convex, and irregularly spaced 0.25 to $0.75 \mathrm{~mm}$ apart. Ratio of tabularium width to corallite diameter about 0.4 . Mode of increase unknown.

Description of holotype. - See Fomichev (1953).

Discussion.-This species is distinguished from $P$. vesiculosus by having larger corallites, more major septa, and generally fewer rows of dissepiments.

Occurrence. -Middle Carboniferous, Moscovian. $\mathrm{L}_{4}$ and $\mathrm{L}_{5}$ Limestones, Donetz Basin, U.S.S.R.

\section{Petalaxis exilis Kozyreva}

Petalaxis exilis Kozyreva, 1974, p. 26, pl. 1, figs. 1a-d.

Diagnosis.-Petalaxis with corallite diameter 5 to 11 $\mathrm{mm}$ and 10 to 14 major septa that ordinarily are short and do not extend to the columella or into the dissepimentarium. Minor septa absent. Columella a simple thickened axial plate ordinarily connected to the counter septum and to the cardinal septum in some corallites. Dissepimentarium composed of 1 to 3 rows of mostly large inflated dissepiments. Tabulae complete, horizontal or slightly elevated toward columella, and irregularly spaced 0.5 to $1.25 \mathrm{~mm}$ apart. Ratio of tabularium width to corallite diameter about 0.4 . Increase probably peripheral.

Description of holotype. - See Kozyreva (1974).

Discussion.-This species is distinguished from $P$. vesiculosus by having fewer septa that extend to the col- 
umella, by lacking minor septa, by having fewer rows of dissepiments, and by having fewer tabulae.

Occurrence.-Middle Carboniferous, Bashkirian. Horizon $\mathrm{b}_{4}$, Voronezh anteclise, U.S.S.R.

\section{Petalaxis confertus Kozyreva}

Petalaxis confertus Kozyreva, 1974, p. 27, pl. 1, figs. 2a, b, 3a; b.

Diagnosis.-Petalaxis with corallite diameter 8 to 12 $\mathrm{mm}$ and 19 to 20 major septa that commonly approach the columella but do not extend into the dissepimentarium. Minor septa absent. Columella a simple thickened axial plate connected to the counter septum. Dissepimentarium composed of 1 to 3 rows of inflated dissepiments of varying sizes. Tabulae mostly incomplete, varying in attitude, and irregularly spaced 0.25 to $1 \mathrm{~mm}$ apart. Ratio of tabularium width to corallite diameter about 0.4 to 0.5 . Mode of increase unknown.

Description of type material. -See Kozyreva (1974).

Discussion. - This species is distinguished from $P$. exilis by having more major septa, longer major septa, and by its incomplete tabulae.

Occurrence. - Middle Carboniferous, Bashkirian. Voronezh anteclise, U.S.S.R.

\section{Petalaxis persubtilis Kozyreva}

Petalaxis persubtilis Kozyreva, 1974, p. 27, pl. 1, figs. 4a-c, 5, 6.

Diagnosis.-Petalaxis with corallite diameter 9 to 15 $\mathrm{mm}$ and 15 to 17 major septa that commonly approach the columella and may or may not extend into the dissepimentarium. Minor septa absent or variably developed. Columella absent or weakly developed as a simple axial plate connected to the counter septum. Dissepimentarium composed of 2 to 4 rows of large inflated dissepiments. Tabulae complete, horizontal, commonly weakly turned up at columella, and irregularly spaced 0.25 to $1 \mathrm{~mm}$ apart. Ratio of tabularium width to corallite diameter 0.3 to 0.4 . Increase peripheral.

Description of type material. - See Kozyreva (1974).

Discussion. - This species is distinguished from $P$. confertus by having larger corallites, more major septa, more rows of dissepiments, and a smaller ratio of tabularium width to corallite diameter.

Occurrence.-Middle Carboniferous, Bashkirian. Horizon $b_{1}$, Voronezh anteclise, U.S.S.R.

Petalaxis korkhovae Kozyreva

Petalaxis korkhovae Kozyreva, 1974, p. 28, pl. 1, figs. 7a-c.

Diagnosis. -Petalaxis with corallite diameter 9 to 15 $\mathrm{mm}$ and 16 to 18 major septa that ordinarily extend about halfway to the columella but seldom extend into the dissepimentarium. Minor septa absent or poorly developed. Columella a simple thickened axial plate connected to the counter septum. Dissepimentarium com- posed of 3 to 4 rows of inflated dissepiments of varying sizes. Tabulae complete, horizontal, mostly flat, and irregularly spaced 0.25 to $1 \mathrm{~mm}$ apart. Ratio of tabularium width to corallite diameter 0.3 to 0.4 . Increase peripheral.

Description of type material. - See Kozyreva (1974).

Discussion. - This species is distinguished from $P$. persubtilis by having a stronger columella, shorter major septa, and flatter tabulae.

Occurrence.-Middle Carboniferous, Bashkirian. Horizon $b_{1}$, Voronezh anteclise, U.S.S.R.

\section{Petalaxis mirus Kozyreva}

Petalaxis mirus Kozyreva, 1974, p. 29, pl. 2, figs. 1a-c.

Diagnosis. - Petalaxis with corallite diameter 7 to 15 $\mathrm{mm}$ and 16 to 18 major septa that ordinarily extend about halfway to the columella but seldom extend into the dissepimentarium. Minor septa absent or very poorly developed. Columella a simple thickened axial plate connected to the counter septum in most corallites but absent in some. Dissepimentarium consists of 1 to 3 rows of large elongate dissepiments. Tabulae complete, horizontal, and spaced about $1 \mathrm{~mm}$ apart. Ratio of tabularium width to corallite diameter about 0.3 to 0.4 Increase peripheral and intermural.

Description of type material. - See Kozyreva (1974).

Discussion.-This species is distinguished by its polymorphic coralla, which include the morphologies of Petalaxis, Sciophyllum, and Thysanophyllum.

Occurrence.-Middle Carboniferous, Bashkirian. Horizon $b_{4}$, Voronezh anteclise, U.S.S.R.

\section{Petalaxis evidens Kozyreva}

Petalaxis evidens Kozyreva, 1974, p. 30, pl. 2, figs. 2a, b, 3.

Diagnosis. - Petalaxis with corallite diameter 8 to 16 $\mathrm{mm}$ and 18 to 22 major septa that extend about twothirds of the way to the columella but seldom extend into the dissepimentarium. Minor septa absent or very poorly developed. Columella a simple thickened axial plate connected to the counter septum. Dissepimentarium consists of 1 to 3 rows of large inflated dissepiments. Tabulae complete and incomplete, horizontal, concave, turned up at the columella, and irregularly spaced 0.25 to $1 \mathrm{~mm}$ apart. Ratio of tabularium width to corallite diameter about 0.3 to 0.4 . Mode of increase unknown.

Description of type material. - See Kozyreva (1974).

Discussion.-This species is distinguished from $P$. korkhovae by having more major septa, longer major septa, and by having its tabulae turned up at the columella.

Occurrence. Middle Carboniferous, Bashkirian. Horizon $b_{4}$, Voronezh anteclise, U.S.S.R. 
Petalaxis maccoyanus species group

Petalaxis maccoyanus Milne-Edwards and Haime

Stylaxis M'coyana Milne-Edwards and Haime, 1851, p. 453, pl. 12, figs. 5, 5a.

Petalaxis M'coyana Milne-Edwards and Haime, 1852, p. 205; MilneEdwards, 1860, p. 440; Roemer, 1883, p. 387.

Lithostrotion Portlocki Milne-Edwards and Haime. Eichwald, 1861, p. $149,150$.

Lithostrotion Mac-Coyanum Milne-Edwards and Haime. Eichwald, 1861, p. 150.

Lithostrotion maccoyanum (Milne-Edwards and Haime). Bassler, 1950 , p. 222.

Petalaxis mccoyana Milne-Edwards and Haime. Fedorowski and Gorianov, 1973 , p. 58 , pl. 12 , figs. $4 \mathrm{a}$, b, text-figs. $20 \mathrm{a}$, b; Sutherland, 1977, p. 185, figs. 1-7.

Not Petalaxis maccoyana Milne-Edwards and Haime. Fomichev, 1953, p. 453, pl. 31, figs. 1a-d, 2a-d.

Not Lithostrotionella maccoyana (Edwards and Haime). de Groot, 1963, p. 82, pl. 16, figs. 1a, b.

Diagnosis.-Petalaxis with maximum corallite diameter 5.4 to $7.8 \mathrm{~mm}$ and 13 to 18 major septa that approach the columella but seldom reach it and seldom extend into the dissepimentarium. Minor septa poorly developed. Columella a thickened axial plate connected to the counter septum augmented in some corallites by vertical axial tabellae and rare, poorly developed septal lamellae. Dissepimentarium composed of 1 to 2 rows of small inflated dissepiments Tabulae mostly incomplete, essentially horizontal, flat, concave, or convex, and irregularly spaced 0.5 to $1 \mathrm{~mm}$ apart. Ratio of tabularium width to corallite diameter about 0.6. Increase peripheral.

Description of type material. - See Milne-Edwards and Haime (1851). According to Sutherland (1977, p. 185), the holotype and paratype are lost and a neotype may have to be designated from a topotype lot in the collections of the Paleontological Institute of the Academy of Sciences of the USSR in Moscow. Pending further work by Sutherland, the diagnosis is based largely on descriptions and illustrations of topotypes published by Fedorowski and Gorianov (1973) and Sutherland (1977).

Discussion. - This species, the type of Petalaxis, has a narrow dissepimentarium like species of the $P$. flexuosus group but is distinguished by its variable columella, which ranges from a simple thickened axial plate to a complex structure made up of axial plate, vertical tabellae, and rare septal lamellae. Specimens of similar general morphology but lacking a complex axial structure were referred to the species by Fomichev (1953) and de Groot (1964) but are here excluded from the species. The only described material included in the species is from the Moscow Basin.

Occurrence.-Middle Carboniferous, Moscovian. Myachkovo Horizon, Moscow Basin, U.S.S.R.
Petalaxis stylaxis (Trautschold)

Lithostrotion stylaxis Trautschold, 1879, p. 36, pl. 5, figs. 6a-c. Petalaxis stylaxis Stuckenberg, 1888, p. 21, pl. 3, figs. 17-21.

?Petalaxis stylaxis Trautschold. Bolkhovitinova, 1915, p. 63, pl. 5, fig. 1.

Lithostrotionella stylaxis (Trautschold). Dobrolyubova, 1935a, p. 10, pl. 1, figs. $1-5$, pl. 2, figs. 1, 2, 5; pl. 13, figs. $1-3 ; 1935$ b, p. 14, pl. 1, figs. 1-5, pl. 2, figs. 1, 2, 5, pl. 13, figs. 1-3; Fomichev, 1939, p. 60 , pl. 9, figs. 6a, b; not Wu and Zhao, 1974, p. 271, pl. 137, figs. 5,6 .

?Lithostrotionella stylaxis (Trautschold). Heritsch, 1937, p. 164, figs. $1-4 ; 1939$, p. 29, pl. 18, fig. 7, pl. 21, figs. 17, 18.

?Lithostrotion [Lithostrotionella] stylaxis (Trautschold). Bassler, 1950, p. 235.

Diagnosis. - Petalaxis with corallite diameter 3.5 to 9 $\mathrm{mm}$ and 11 to 18 major septa that approach the columella but seldom reach it and seldom extend into the dissepimentarium. Minor septa absent to well developed. Columella ranging from a simple axial plate ordinarily connected to the counter septum to a complex structure in which the axial plate is augmented by impersistent vertical axial tabellae and rare septal lamellae. Dissepimentarium composed of 1 to 3 rows of inflated dissepiments of varying sizes. Tabulae complete and incomplete, horizontal, flat, concave or convex, and irregularly spaced 0.25 to $2 \mathrm{~mm}$ apart. Ratio of tabularium width to corallite diameter 0.4 to 0.7 . Mode of increase unknown.

Description of type material. - See Trautschold (1879). The diagnosis is taken largely from Dobrolyubova's (1935b) descriptions and illustrations of topotypes.

Discussion. - Dobrolyubova (1935a, b) recognized three morphological variants in her study of topotypes: Lithostrotionella stylaxis, $L$. stylaxis var. 1 , and $L$. stylaxis var. 2. These were treated like separate species in a morphological series. The three morphotypes were collected from the same horizon at different geographic locations, all in the Moscow Basin. Pending further study, I have included all three morphotypes in the concept of Petalaxis stylaxis.

Bolkhovitinova's (1915) specimen is included here with a question because of inadequate description and illustration. Heritsch's $(1937,1939)$ specimens are referred questionably to the species because no longitudinal sections are available.

Petalaxis stylaxis differs from $P$. maccoyanus by having slightly larger corallites, an unthickened columella, and some well-developed minor septa.

Occurrence.-Middle Carboniferous, Moscovian. Myachkovo Horizon $\left(\mathrm{C}_{2}{ }^{4}\right)$, Moscow Basin, U.S.S.R. Corakalk, Kings Bay, Spitzbergen(?). Arabian Desert(?).

\section{Petalaxis mohikanus (Fomichev)}

Lithostrotionella mohikana Fomichev, 1939, p. 60, pl. 9, figs. 5a, b. Petalaxis mohikana Fomichev, 1953, p. 459, pl. 32, figs. 1a, b, 2a, b, pl. 33 , fig. 1 . 
Diagnosis. -Petalaxis with corallite diameter 6 to 10 $\mathrm{mm}$ and 13 to 18 major septa that closely approach the columella and commonly extend into the dissepimentarium. Minor septa well developed. Columella ordinarily a simple axial plate but augmented by rare short septal lamellae and a few vertical axial tabellae in some corallites. Dissepimentarium composed of 1 to 3 rows of mostly large inflated dissepiments. Tabulae complete and incomplete, essentially horizontal, commonly turned up at columella, and spaced 0.25 to $0.5 \mathrm{~mm}$ apart. Ratio of tabularium width to corallite diameter about 0.4 to 0.5. Mode of increase unknown.

Description of type material. - See Fomichev (1953).

Discussion. - This species differs from $P$. maccoyanus by having larger corallites, more extensions of the major septa into the dissepimentarium, well-developed minor septa, and more tabulae.

Occurrence.-Middle Carboniferous, Moscovian. $\mathrm{M}_{3}$ Limestone, Donetz Basin, U.S.S.R.

Petalaxis celadensis (de Groot)

Lithostrotionella celadensis de Groot, 1963, p. 82, pl. 15, figs. 2a-d.

Diagnosis. - Petalaxis with corallite diameter 3.5 to 6 $\mathrm{mm}$ and 12 to 16 major septa that extend about halfway to the columella but seldom extend into the dissepimentarium. Minor septa absent or poorly developed. Columella ranging from a simple axial plate connected to the counter septum to a complex structure composed of an axial plate, vertical axial tabellae, and a few septal lamellae. Dissepimentarium composed of 1 to 2 rows of large inflated dissepiments. Tabulae mostly incomplete, flat to concave, horizontal, and irregularly spaced 0.25 to $0.75 \mathrm{~mm}$ apart. Ratio of tabularium width to corallite diameter about 0.6. Mode of increase unknown.

Description of holotype. - See de Groot (1964 [1963]).

Discussion. - This species differs from $P$. maccoyanus by having smaller corallites, fewer and shorter major septa, weaker minor septa, and more tabulae.

Occurrence. - Middle Carboniferous, Moscovian. Celada Limestone, Palencia, Spain.

Petalaxis elyensis (Wilson and Langenheim)

Eastonoides elyensis Wilson and Langenheim, 1962, p. 512, pl. 88, figs. 4-6.

Diagnosis. -Petalaxis with corallite diameter 4 to 5 $\mathrm{mm}$ and 10 to 15 major septa that extend about halfway to the columella. Major septa are attached to the corallite wall except where impersistent lonsdaleoid dissepiments are present. Minor septa poorly developed, contratingent. Columella a thickened axial plate connected to the counter septum and augmented by rare impersistent vertical axial tabellae and very rare septal lamellae. Dissepimentarium consists of a single row of impersistent inflated dissepiments. Tabulae mostly complete, generally flat, locally sagging or domed, and spaced 0.5 to $1 \mathrm{~mm}$ apart. Tabularium width equals corallite diameter, except where dissepiments are developed. Mode of increase unknown.

Description of type material.-See Wilson and Langenheim (1962).

Discussion. - This species is distinguished from most other species of Petalaxis by having an impersistent lonsdaleoid dissepimentarium and impersistent axial tabellae. $P$. elyensis is the type species of Eastonoides Wilson and Langenheim, which was proposed to include the type species and Lonsdaleia ivanovi Dobrolyubova, which Fomichev (1953, p. 464) included in Cystolonsdaleia. These species have the general morphology of $P$. maccoyanus, the type species of Petalaxis, which also has impersistent axial tabellae. Thus, Eastonoides is regarded as a junior synonym of Petalaxis, and $P$. elyensis is included in the $P$. maccoyanus species group.

Occurrence-Lower Permian. Ely Limestone, Nevada, U.S.A.

Petalaxis dobrolyubovae n. sp.

Not Stylaxis portlocki Milne-Edwards and Haime, 1851, p. 453.

Not Petalaxis portlocki Milne-Edwards and Haime, 1852, p. 204, pl. 38, figs. 44, 4a; Haime, 1860, p. 441.

Petalaxis portlocki Edwards and Haime. Stuckenberg, 1888, p. 22, pl. 2, figs. 44-49.

Lonsdaleia portlocki (Stuckenberg). Dobrolyubova, 1935a, p. 12, pl. 9, figs $1-4$, not pl. 10, figs. 1, 2; 1935b, p. 29, pl. 9, figs. 1-4, not pl. 10 , figs. $1,2$.

Not Cystolonsdaleia portlocki (Dobrolyubova). Fomichev, 1953, p. 467, pl. 32 , figs. $4 \mathrm{a}-\mathrm{v}$.

Not Lonsdaleia portlocki (Stuckenberg) densiconus de Groot, 1963, p. 79 , pl. 15, fig. 1.

Diagnosis. - Petalaxis with corallite diameter 5 to 11 $\mathrm{mm}$ and 11 to 17 major septa that extend halfway to or closely approach the columella but seldom reach it and commonly extend into the dissepimentarium. Minor septa absent to well developed. Columella ranging from a simple axial plate connected to the counter septum to a complex structure composed of axial plate, vertical axial tabellae, and rare septal lamellae augmented by stereoplasm in some corallites to produce a netlike structure in transverse section. Dissepimentarium composed of 1 to 2 rows of inflated dissepiments of varying sizes. Tabulae mostly incomplete, flat, concave, or convex, horizontal, and irregularly spaced 0.25 to $1 \mathrm{~mm}$ apart. Ratio of tabularium width to corallite diameter about 0.6 to 0.7 . Mode of increase unknown.

Description of type material.-See Dobrolyubova (1935b). The holotype is the specimen illustrated by Dobrolyubova (1936b) as her plate 9, figures 1 and 2 .

Discussion.-Dobrolyubova's illustrations suggest that more than one species may be present in the type lot. I exclude the specimen figured as her plate 10, figures 1 and 2 , because it seems much more complex 
than the other two specimens illustrated. The remaining figured specimens are notably different from one another but are retained in the species concept pending further work on the type material.

Cystolonsdaleia portlocki (Dobrolyubova) Fomichev does not belong here and is described below as a new species. Lonsdaleia portlocki (Stuckenberg) densiconus de Groot is a separate species assigned to Cystolonsdaleia Fomichev.

$P$. dobrolyubovae differs from $P$. maccoyanus by having larger corallites, more abundant complex columellae, and more extensions of the major septa into the dissepimentarium.

Occurrence.-Middle Carboniferous, Moscovian. Myachkovo Horizon, Moscow Basin, U.S.S.R.

Petalaxis donetsensis $\mathbf{n}$. sp.

Cystolonsdaleia portlocki (Dobrolyubova). Fomichev, 1953, p. 467, pl. 32 , figs. 4a-v.

Diagnosis. - Petalaxis with corallite diameter 8 to 10 $\mathrm{mm}$ and 13 to 16 major septa that approach the columella but do not ordinarily reach it and seldom extend into the dissepimentarium. Minor septa absent or poorly developed. Columella ranging from a simple axial plate connected to the counter septum to a more complex structure composed of axial plate and impersistent vertical axial tabellae. Dissepimentarium composed of 2 to 4 rows of inflated dissepiments of varying sizes. Tabulae mostly incomplete, mostly concave, horizontal, and irregularly spaced 0.25 to $1 \mathrm{~mm}$ apart. Ratio of tabularium width to corallite diameter about 0.3 to 0.6 . Mode of increase unknown.

Description of holotype.-See Fomichev (1953). The holotype is specimen number 36 of Fomichev.

Discussion. - This species differs from $P$. dobrolyubovae by having more rows of dissepiments, weaker minor septa, a smaller ratio of tabularium width to corallite diameter, and by its less abundant complex columellae.

Occurrence.-Middle Carboniferous, Moscovian. $\mathrm{N}_{1}$ Limestone, Donetz Basin, U.S.S.R.

\section{Petalaxis ivanovi (Dobrolyubova)}

Lonsdaleia ivanovi Dobrolyubova, 1935a, p. 12, pl. 11, figs. 1, 2; 1935b, p. 31, pl. 11, figs. 1, 2.

Diagnosis. - Petalaxis with corallite diameter 6 to 6.5 $\mathrm{mm}$ and 13 to 14 major septa that closely approach the columella but seldom reach it. Major septa are attached to the corallite wall, except where impersistent lonsdaleoid dissepiments are present. Minor septa well developed. Columella ranging from a simple axial plate to a complex structure consisting of axial plate, vertical axial tabellae, and a few septal lamellae commonly reinforced by stereoplasm to form a thick rod or netlike structure in transverse section. Dissepimentarium impersistent, composed of a single row of dissepiments of varying sizes where present. Tabulae mostly incomplete, horizontal, flat, concave, or convex, and irregularly spaced 0.25 to $1 \mathrm{~mm}$ apart. Tabularium width equals corallite diameter except where dissepiments are present. Mode of increase unknown.

Description of holotype. - See Dobrolyubova (1935b).

Discussion. - This species differs from $P$. elyensis by having larger corallites, stronger minor septa, and a better developed complex columella.

Occurrence.-Middle Carboniferous, Moscovian. Myachkovo Horizon, Moscow Basin, U.S.S.R.

\section{Petalaxis? spp. indet.}

The following taxa are referred questionably to Petalaxis and are not diagnosed because of insufficient illustration or description of morphological details:

Lithostrotionella tingi Chi, 1931, p. 28, pl. 4, figs. 6a, b; Wu in Yü and others, 1963, p. 86, pl. 24, figs. 6a, b. Middle Carboniferous, Moscovian. Laokunchai Limestone, Kueichou, China.

Lithostrotionella aff. stylaxis Trautschold. Dobrolyubova, $1936 \mathrm{~b}$, p. 127 , figs. 55, 56. Middle Carboniferous, Moscovian. Ural Mountains, U.S.S.R.

Lithostrotionella sp. indet. Yamagiwa, 1961, p. 102, pl. 5, figs. 1-3. Lower Permian. Atetsu Limestone, Okayana, Japan.

Lithostrotionella kitakamiensis Minato, 1955, p. 88, pl. 4, figs. 2, 7, 8, 10, pl. 34, figs. 2, 3. Middle Carboniferous, Bashkirian. Nagaiwa Series, Iwate, Japan.

Lithostrotionella spiniformis Yü, 1933 [1934], p. 102, pl. 21, figs. 2a, b; Wu in Yü and others, 1963, p. 87, pl. 24, figs. 5a, b. Lower Carboniferous, Viséan. Shangssu Limestone, Kueichou, China.

Petalaxis timanicus Stuckenberg. Heritsch, 1939, p. 18, pl. 2, fig. 8, pl. 3, fig. 1, pl. 15, figs. 2, 3, pl. 21, figs. 8-16. Carboniferous or Permian. Cora Limestone, Spitzbergen.

Petalaxis timanicus Stuckenberg. Kolosvary, 1951, p. 39, pl. 9, figs. 5-7. Permian, Hungary.

Petalaxis maccoyana var. multiseptata Fomichev, 1953, p. 458, pl. 31, fig. 4. Middle Carboniferous, Moscovian. $\mathrm{L}_{5}$ Limestone, Donetz Basin, U.S.S.R.

Petalaxis maccoyana forma orlovkensis Fomichev, 1953; p. 456. Middle Carboniferous, Moscovian. $\mathrm{L}_{5}$ and $\mathrm{L}_{6}$ Limestone, Donetz Basin, U.S.S.R.

\section{Family LONSDALEIIDAE Chapman, 1893}

Genus THYSANOPHYLLUM Nicholson and Thomson, 1876

Thysanophyllum Nicholson and Thomson, 1876, p. 150; Hill, 1940, p. 160. 
Type species.-Thysanophyllum orientale Nicholson and Thomson, 1876, p. 150. Lower Carboniferous, Scotland.

Discussion. - Thysanophyllum is distinguished by its cerioid corallum having corallites with a lonsdaleoid dissepimentarium and lacking an axial structure or having a weak impersistent axial plate. The genus is probably polyphyletic like other colonial rugose corals without a persistent axial structure, corals such as Diphyphyllum and Pseudodorlodotia.

Thysanophyllum astraeiforme (Warren)

Diphyphyllum astraeiformis Warren, 1927, p. 44, pl. 3; figs. 2 , 3. Lithostrotionella astraeiformis (Warren). Kelly, 1942, p. 352; Bamber, 1961, p. 152, pl. 12, figs. 1a, b; Nelson, 1961, pl. 18, figs. 1-3.

Lithostrotionella (Thysanophyllum) astraeiformis (Warren). Nelson, 1960, p. 115, pl. 22, figs. 7-10.

Thysanophyllum astraeiforme (Warren). Bamber, 1966, p. 23, pl. 4, figs. 3a-b, 4a-c; Armstrong, 1970a, p. 37, pl. 11, figs. 5-8; 1970b, p. 28 , pl. 9, figs. 1-6, text-fig. 33 .

Description of lectotype. - See Bamber (1966).

Discussion.-This species is rather common in western Canada and Alaska, where it ranges from Mamet Zone 13 into 16i; it is most common in Mamet Zones 14 and 15. These occurrences are of middle and late Viséan age. The structure of the columella, where present, suggests relationship to Acrocyathus.

Genus LONSDALEIA McCoy, 1849

Lonsdaleia McCoy, 1849, p. 11; Smith, 1916, p. 218; Hill, 1940, p. 151; Sando, 1975, p. C20.

Type species.-Erismatolithus Madreporites (duplicatus) Martin, 1809, equals Lonsdaleia duplicata (Martin). Lower Carboniferous, England.

Diagnosis. - See Cotton (1973, p. 117).

Discussion.-The genus is subdivided into two subgenera on the basis of growth form: Lonsdaleia (Lonsdaleia), phaceloid, and Lonsdaleia (Actinocyathus), cerioid.

\section{Subgenus ACTINOCYATHUS d'Orbigny, 1849}

Actinocyathus d'Orbigny, 1849a, p. 12.

Stylidophyllum de Fromentel, 1861, p. 316.

?Protolonsdalia Lisitsyn, 1925, p. 68.

?Sublonsdalia Lisitsyn, 1925, p. 68.

?Protolonsdaleia Lang, Smith, and Thomas, 1940, p. 106.

?Sublonsdaleia Lang, Smith, and Thomas, 1940, p. 128

Type. species.-Cyathophyllum crenulare Phillips, 1836, equals Erismatolithus Madreporites (floriformis) Martin, 1809, equals Lonsdaleia floriformis (Martin). Lower Carboniferous, England.

Diagnosis. - Cerioid Lonsdaleia.

Discussion. - See Sando (1975, p. C20) for discussion of the type species and synonymic placement of Stylidophyllum. Protolonsdalia (nomen vanum Protolonsdaleia) and Sublonsdalia (nomen vanum Sublonsdaleia) are both inadequately founded on type material that has been lost (N. P. Vasilyuk, oral commun., 1975); they may be junior synonyms of $A c$ tinocyathus, but neotypes need to be described before a final decision can be made.

Lonsdaleia (Actinocyathus) berthiaumi (Mernam)

Plate 20, figures 3, 4

Lithostrotion (Lithostrotionella) berthiaumi Merriam, 1942, p. 378, pl. 56, figs. 9, 10; Bassler, 1950, p. 252.

Description of holotype. - See Merriam (1942).

Discussion.-Lonsdaleia (Actinocyathus) was previously represented in North America by a single species, $L$. (A.) stelcki Nelson (1960, p. 119, pl: 23, figs. 6-10), as determined by Sando (1975, p. C21). Nelson's species is restricted to the upper Viséan and lower Namurian (Mamet Zones 16s, 17, and 18). Examination of the holotype (USNM 132988) and a topotype (USNM 132989) of Merriam's species reveals that it is very similar to Nelson's species but differs in having fewer tabulae. New thin sections of Merriam's holotype (USNM 132988) are figured herein to provide a better basis for interpreting this specimen.

Merriam (1942, p. 379) stated that the type material of $L$. berthiaumi is from the Permian Coyote Butte Formation of Oregon, a stratigraphic level that is inconsistent with other North American occurrences of the genus to which it is now assigned. According to E. C. Wilson (written commun., 1979), exposures in the type area are poor, geologic structure is complex, and beds in the area range from Devonian to Permian. I conclude that the specimens are probably from beds of Carboniferous (late Viséan or early Namurian) age.

Lonsdaleia (Actinocyathus) peratrovichensis (Armstrong)

Lithostrotionella peratrovichensis Armstrong, 1970a, p. 35, pl. 12, figs. 8-11.

Description of holotype. - See Armstrong (1970a).

Discussion.-Examination of the holotype (USNM 160493) of $L$. peratrovichensis reveals a morphology consistent with Lonsdaleia (Actinocyathus). The species differs from the widely distributed $L$. (A.) stelcki (Nelson) by its smaller corallite diameter, thicker corallite walls, fewer dissepiments, and tabulae of varying form, some of which are inclined upward toward the columella.

The presence of $L$. (A.) peratrovichensis in beds of late Viséan age and the nature of its tabulae suggest that it is ancestral to $L$. (A.) stelcki.

Family DURHAMINIDAE Minato and Kato, 1965

Genus KLEOPATRINA McCutcheon and Wilson, 1963

Ptolemaia McCutcheon and Wilson, 1961, p. 1020 (not Osborn, 1908, p. 267).

Kleopatrina McCutcheon and Wilson, 1963, p. 299; Minato and Kato, 1965, p. 67 (replacement name for Ptolemaia McCutcheon and Wilson). 
Type species. - Ptolemaia ftatateeta McCutcheon and Wilson, 1961, p. 1025, pl. 123, figs. 1-6. Lower Permian, Nevada.

Diagnosis. -See Minato and Kato (1965).

Discussion. - This genus is found predominantly in Permian strata, although Bamber and Macqueen (1979, p. 11) reported Kleopatrina (Porfierevella) from beds of Moscovian Age in British Columbia. The two species questionably referred here (see below) are the first possible representatives from the Upper Carboniferous.

Subgenus KLEOPATRINA McCutcheon and Wilson, 1963

Type species. - As for genus Kleopatrina.

Diagnosis. -See Minato and Kato (1965).

Kleopatrina (Kleopatrina)? dilatata (Easton)

Lithostrotion [Lithostrotionella] dilatata Easton, 1960, p. 578, textfigs. $7,8$.

Description of holotype. - See Easton (1960).

Discussion. -Judging from Easton's description and illustrations, the type material of this species has most of the essential features of Kleopatrina (Kleopatrina). However, the types do not seem to have a complex axial structure, which casts doubt on the taxonomic placement. The type material needs to be reinvestigated.

Occurrence. - Permian. Arcturus and Rib Hill Formations, Nevada, U.S.A.

Kleopatrina (Kleopatrina)? uralica (Dobrolyubova)

Lithostrotionella uralica Dobrolyubova, 1936a, p. 28, pl. 13, figs. 33-35.

Description of type material.-See Dobrolyubova (1936a).

Discussion. - Dobrolyubova's description and illustrations of this species suggest that it may be an early representative of Kleopatrina (Kleopatrina). This species occurs in beds of Late Carboniferous age, whereas all other known representatives of the subgenus are from the Permian. The type material needs to be reinvestigated.

Kleopatrina (Kleopatrina)? wahooenis (Armstrong)

Lithostrotionella wahooenis Armstrong, 1972b, p. 14, pl. 5, fig. 1, pl. 6, figs. 1-5, pl. 7, figs. 1-3.

Description of holotype and paratypes.-See Armstrong (1972b).

Discussion.-Armstrong's holotype and paratypes have the essential morphological characters of Kleopatrina (Kleopatrina). Differences between these specimens and the holotype of $K$. (K.) ftatateeta seem to be of specific rank only. However, Armstrong's species is from beds that are much older than those in which other known species of the subgenus are found. The occurrence is Middle Pennsylvanian (Atokan) Mamet Zone 21, which equates with high Bashkirian or low Mosco- vian of the U.S.S.R. Because of possible homeomorphism with the Permian forms, the placement of this species in Kleopatrina (Kleopatrina) is made with question.

\section{UNDETERMINED LITHOSTROTIONELLOID CORALS}

The following taxa are not identified generically because of inadequate specimens or inadequate illustrations and descriptions:

Lithostrotionella americana Hayasaka, 1936, p. 62 (Paratypes, USNM 174371 and 174373). Permian. McCloud Limestone, California, U.S.A.

Lithostrotionella flexuosa (Trautschold). Heritsch, 1940, p. 72, pl. 2, figs. 1, 2. Upper Carboniferous, Yugoslavia.

Petalaxis grandis Heritsch, 1939, p. 27, pl. 2, figs. 4, 5, pl. 19, fig. 11. Carboniferous or Permian, Spitzbergen.

Petalaxis? inconfertus Lonsdale. Yanishevskiy, 1900, p. 89. Carboniferous, Ural Mountains, U.S.S.R.

Petalaxis indigae Stuckenberg, 1895, p. 76, pl. 19, fig. 7. Upper Carboniferous, Timan, U.S.S.R.

Lithostrotionella kuechouensis Yü, [1933] 1934, p. 101, pl. 21, figs. 1a, b; Wu in Yü and others, 1963, p. 87, pl. 25, figs. 1a, b. Lower Carboniferous, Viséan. Shangssu Limestone, Kueichou, China.

Petalaxis kunthi Stuckenberg, 1888, p. 23; 1895, p. 78, pl. 12, fig. 7; Heritsch, 1939, p. 25, pl. 11, fig. 1, pl. 13, figs. 3, 7, pl. 19, fig. 4. Upper Carboniferous, Moscow Basin and Ural Mountains, U.S.S.R. Carboniferous or Permian, Spitzbergen.

Petalaxis sibiricus Gabounia, 1919, p. 39, pl. 2, fig. 2, pl. 3, fig. 1; Fomichev, 1931, p. 44, 72, pl. 1, figs. 2a-e; 1955, p. 303, pl. 80, figs. 5, 6. Lower Carboniferous, Kuznetsk Basin, U.S.S.R.

Lithostrotionella stylaxis (Trautschold). Rukhin, 1938, p. 40, pl. 5, figs. 7-9. Lower Carboniferous, Siranka River basin, U.S.S.R.

Lithostrotionella stylaxis (Trautschold). Wu and Zhao, 1974, p. 271, pl. 137, figs. 5, 6. Middle Carboniferous, Wei-Ling Group, Kueichou, China.

Petalaxis timanicus Stuckenberg, 1895, p. 76, pl. 12, fig. 5. Upper Carboniferous, Ural Mountains and Timan, U.S.S.R.

Lithostrotionella tingi Chi. Yü, Lin and Fan, 1962, p. 24, pl. 4, figs. 3a, b. Middle Carboniferous, Sinkiang, China.

Styllophyllum tolmachevi Rukhin, 1938, p. 41, pl. 5, figs. 10, 11. Lower Carboniferous, Omulevka River, U.S.S.R.

Petalaxis uchtensis Stuckenberg, 1895, p. 77, pl. 12, fig. 2, pl. 16,fig. 4. Upper Carboniferous, Timan, U.S.S.R. 
Lithostrotionella cf. spiniformis Yü. Wu, 1964, p. 35, 79, pl. 4, figs. 7, 8. Lower Carboniferous, Viséan. Hunan, China.

Lithostrotionella sp. B. Lo and Chao, 1962, p. 184, pl. 22, fig. 6. Lower Carboniferous, Viséan. Ching-hai, China.

Lithostrotionella sp. Kolosvary, 1951, p. 38, pl. 10, figs. 4-9,pl. 18, figs. 1-3. Carboniferous or Permian, Hungary.

Lithostrotionella sp. Dobrolyubova, 1936a, p. 29, pl. 13, figs. 36, 37. Upper Carboniferous, Ural Mountains, U.S.S.R.

Lithostrotionella sp. undet. Minato, 1955, p. 87, pl. 1, fig. 3, pl. 34, fig. 11, pl. 37, fig. 9. Lower Carboniferous, Iwate, Japan.

Lithostrotionella? sp. Ross and Ross, 1963, p. 418, pl. 49, figs. 1, 2, 4, 10. Upper Carboniferous, Virgilian. Gaptank Formation, Texas, U.S.A.

\section{ADDITIONAL TAXA}

While the manuscript was being processed for publication, several additional studies of lithostrotionelloid corals described under the names of Hillia, Lithostrotionella, Petalaxis, Stelechophyllum, and Thysanophyllum came to my attention. Translations of the descriptions of these taxa that are in Chinese and Russian papers were not available at the time, preventing a complete evaluation of them. Moreover, taxa in the Chinese papers are poorly illustrated. These additional taxa are listed below, by publication.

Fan, Y. N., 1978, in Southwest China Geological Institute, [Paleontological atlas of southwestern China, Sichuan Province]: v. 2, 684 p., 191 pls. (In Chinese.) See p. 182-184.

Lithostrotionella maccoyana (Edwards and Haime)

L. sexangula de Groot

L. mui (Lo)

L. fugimotoi (Igo)

L. orboensis de Groot

$L$. orboensis regularis Fan, n.subsp.

L. pinguis Fan, n. sp.

L. awenggouensis Fan, n. sp.

L. vesiculosa vesiculosa Fan, n. subsp.

?L. sp.

Stelechophyllum ascendens ascendens (Tolmachev)

$S$. ascendens simplex Drobolyubova

Gorskiy, I. I., 1978, Korally Srednego Karbona zapadnogo sklona Urala [The Middle Carboniferous corals of the western slope of the Urals]: Akademiya Nauk SSSR, Otdelenie Geologii, Geofiziki, i Geokhimi, Izdatelstvo "Nauka," 223 p., 23 pls., 43 figs. See p. 150-152.
Lithostrotionella stylaxis (Trautschold) subsp. uralica Gorskiy, n. subsp.

L. flexuosa (Trautschold)

Guo, Z. C., 1976, in Northeastern Geological Institute and Geological Bureau of Inner Mongolia, [Paleontological atlas of northern China, part of Inner Mongolia]: v. 1, 502 p., 232 pls. (In Chinese.) See p. 86.

Lithostrotionella ivanovi Dobrolyubova

L. banffense (Warren)

Wang, H. D., 1978, in Stratigraphic-Paleontological Working Team of Guizhou Province, [Paleontological atlas of southwestern China, Guizhou Province]: v. 2, 638 p., 165 pls. (In Chinese.) See p. 133-140.

Lithostrotionella kueichouensis Yü

L. kuechouensis magna Wang, n. subsp.

L. baijinensis Wang, n. sp.

L. multivesiculata Wang, $\mathrm{n}$. sp.

L. spiniformis Yü

L. changshunensis Wang, n. sp.

L. stylaxis (Trautschold)

L. tingi Chi

L. dushanensis Wang, n. sp.

L. elegantula (Wu and Zhao)

L. jiaruoensis Wang, n. sp.

Hillia perapertuensis de Groot

H. minor (Wu and Zhao)

Wilson, E. C., 1982, Wolfcampian rugose and tabulate corals (Coelenterata: Anthozoa) from the Lower Permian McCloud Limestone of northern California: Los Angeles County Natural History Museum Contributions in Science no. 337, 90 p., 48 figs. See p. $65-73$.

Petalaxis allisonae Wilson, n. sp.

$P$. besti Wilson, n. sp.

$P$. kennedyi Wilson, n. sp.

$P$. pecki Wilson, n. sp.

$P$. sutherlandi Wilson, n. sp.

$\mathrm{Xu}, 1977$, in Central Southern Geological Institute and Geological Bureaus of Henan, Hubei, Hunan, Guangdong, and Guangxi Provinces, [Paleontological atlas of central southern China]: v. 2, 856 p., 253 pls. (In Chinese.) See p. 202-203.

Lithostrotionella hsujiulingi Yoh

L. micra Kelly

L. maccoyana (Edwards and Haime)

Thysanophyllum ascendens ascendens (Tolmachev)

T. ascendens simplex (Dobrolyubova)

Yü, C. C., Lin, I. T., Huang, C. H., and Tsai, T. S., 1978, [Early Carboniferous stratigraphy and corals of eastern Xinjiang]: Chinese Academy of Geological Sciences, Editorial Committee of Professional Papers of Stratigraphy and Paleontology, Profes- 
sional Papers of Stratigraphy and Paleontology No. 5, p. 1-70, 10 figs., 16 pls. (In Chinese with English summary.) See p. 29, 38-40. Peking, Geological Publishing House)

Lithostrotionella shimeri (Crickmay)

L. pennsylvanica (Shimer)

L. crassus n. sp.

\section{REGISTER OF USGS LOCALITIES FOR HAYASAKA (1936) TYPE SPECIMENS OF LITHOSTROTIONELLA SPECIES}

83-PC: Newman Limestone, St Louis Limestone Member. West side of Roundstone Creek, $300 \mathrm{ft}(100 \mathrm{~m})$ above creek, about $0.5 \mathrm{mi}(0.8$ $\mathrm{km}$ ) south of site of town of Langford near intersection of Roundstone Creek and Renfro Creek, southeast quarter of Wildie quadrangle, Rockcastle County, Ky. Collected by F. B. Weeks, June 29, 1896. See Gualtieri (1968) for geologic map.

104-PC: Lodgepole Limestone (Zone $\mathrm{C}_{1}$ of Sando and others, 1969).Sec. 12, T. 11 S., R. 44 E., Montpelier quadrangle, Bear Lake County, Idaho. Collected by G. R. Mansfield, June 12, 1911. This collection is composed of two lots, one that has a fauna from the upper part of the Lodgepole Limestone and another that contains Faberophyllum and is from the Aspen Range Formation.

346C-PC: Boulders of residual chert derived from Tuscumbia Limestone (St. Louis Limestone equivalent) at unconformity at top of Tuscumbia Limestone. Along pike about $0.5 \mathrm{mi}(0.8 \mathrm{~km})$ southwest of Cherokee, probably in $\mathrm{SE}^{1 / 4} \mathrm{sec}$. 34 or SW1/4 sec. 35, T. 3 S., R. 14 W., Cherokee quadrangle, Colbert County, Ala. Collected by P. V. Roundy, 1911. See Butts (1926) for geologic map of the area. See McCalley $(1896$, p. 152-153, 158) and Butts $(1926$, p. 175) for description of the geology.

490-PC: Float from Lodgepole Limestone (Zone $C_{1}$ of Sando and others, 1969). Old Laketown Canyon, near center of sec. 32, T. 13 N., R. 6 E., Randolph quadrangle, Rich County, Utah. Collected by G. B. Richardson, 1912. See Richardson (1941) for geologic map and Sando and others (1959) for discussion of geology.

498-PC: St. Louis Limestone, at base. Outskirts of Maeystown, probably in bed of Maeystown Creek about $1 \mathrm{mi}(1.6 \mathrm{~km})$ southeast of Maeystown in SW1/4 sec. 1, T. 4 S., R. 11 W., Selma quadrangle, Monroe County, Ill. Collected by G. H. Girty, September 8, 1912.

499-PC: St. Louis Limestone, basal beds just above cephalopod bed. Ravine in river bluff about $1 \mathrm{mi}(1.6 \mathrm{~km})$ southeast of Maeystown, probably in $\mathrm{SE}^{1 / 4} \mathrm{sec} .1$ or NE1/4 sec. 12 , T. 4 S., R. 11 W., Selma quadrangle, Monroe County, Ill. Collected by Weller and Girty, September 8, 1912.

643-PC: St. Louis Limestone(?). On Tebo Creek about $1.5 \mathrm{mi}(2.4 \mathrm{~km})$ east of Leesville, Leesville quadrangle, Henry County, Mo.(?). Collected by W. P. Jenney, 1891.

Original locality data indicate that the stratigraphic unit was probably the Cherokee limestone or Seneca chert of Jenney (1894), which Jenney thought to be of Warsaw or St. Louis age. According to Wilmarth $(1938$, p. 415), subsequent authors regarded the Cherokee limestone as Boone Formation and the Seneca chert as the Grand Falls Chert Member of the Boone. According to Wilson (1922, p. 180), most of Henry County is underlain by the Cherokee Shale of Pennsylvanian age, but the Burlington and Keokuk Limestones are exposed beneath the Cherokee in the valley of Tebo Creek.

Hayasaka's specimen attributed to this locality is surely a St. Louis Limestone form. Thus, the locality data may be erroneous or the specimen may be a residual fragment derived from the St.
Louis Limestone during post-St. Louis, pre-Cherokee erosion. There are no other specimens in the collection.

932A-PC: Float from St. Louis Limestone. In cut of St. Louis and San Francisco Railroad in $\mathrm{NE}^{1 / 4} \mathrm{SE}^{1 / 4}$ or $\mathrm{SE}^{1 / 4} \mathrm{NE}^{1 / 4} \mathrm{sec}$. 10, T. 4 N., $R$. 5 E., Kirkwood quadrangle, St. Louis County, Mo. Collected by G. H. Girty, August 8, 1904. See Fenneman (1911, pl. 1) for geologic map of the area.

970-PC: Alapah Limestone(?). 141st meridian, easterly spur from ridge between headwaters forks of Incog Creek, about $2 \mathrm{mi}(3.2$ $\mathrm{km})$ northwest from station 966, Table Mountain quadrangle, northeastern Alaska. Collected by A. G. Maddren, July 1, 1912.

1148-PC: Float from St. Louis Limestone. $3 \mathrm{mi}(4.8 \mathrm{~km})$ west of Tennessee, Ill., in NW11/4 SW1/4 sec. 19, T. 5 N., R. 4 W., Colchester quadrangle, McDonough County, Ill. Collected by Henry Hinds, November 22, 1912. See Hinds (1919) for geologic map.

1211B-PC: Oolite in lower part of St. Louis Limestone. Mosher quarry (Ste. Genevieve Lime and Quarry Company) at Macy (Mosher Station) about $2 \mathrm{mi}(3.2 \mathrm{~km})$ southwest of Ste. Genevieve on Illinois Southern Railroad in T. 38 N., R. 9 E., Weingarten quadrangle, Ste. Genevieve County, Mo. Collected by E. O. Ulrich, November 2, 1903. See Weller and St. Clair (1928) for geologic map of the area.

1439-PC: Lodgepole Limestone, Woodhurst Member (Zone $\mathrm{C}_{1}$ of Sando and others, 1969). In low saddle on west slope of hill (altitude 8,172 ft $(2,490 \mathrm{~m})$ ) west of Georgetown Canyon, NW1/4 sec. 34, T. 10 S., R. 44 E., Slug Creek quadrangle, Bear Lake County, Idaho. Collected by G. H. Girty, November 11, 1914. This locality was mapped as Madison Limestone by Mansfield (1927, pl. 6). Megafossils associated with the coral specimen are all compatible with a Zone $\mathrm{C}_{1}$ determination.

1476-PC: Aspen Formation (Mamet foraminifer Zone 14). SW1/4 sec. 8, T. 5 S., R. 43 E., at altitude $6,650 \mathrm{ft}(2,015 \mathrm{~m})$ in point projecting north from ridge south of Grays Lake, Lanes Creek quadrangle, Caribou County, Idaho. Collected by E. L. Jones and G. H. Girty, November 5,1914 . This locality was mapped as Brazer Limestone by Mansfield (1927, pl. 4). The file card by Girty indicates "near top" of the Brazer, but this locality is in a fault block, so the position is doubtful. Microfossils in the collection indicate Mamet Zone 14, and megafossils indicate Zone $\mathrm{E}$ of Sando and others (1969).

2013B-PC: Greenbrier Limestone, Hillsdale Member, near base. In cut of Norfolk and Western Railroad along Indian Creek $1.5 \mathrm{mi}$ $(2.4 \mathrm{~km})$ northeast of Cedar Bluff, Tazewell quadrangle (30-minute) and Pounding Mill quadrangle (15-minute), Tazewell County, Va. Collected by G. H. Girty, June 17, 1920. See Campbell (1897) for geologic map of the area.

2020-PC: Greenbrier Limestone, Hillsdale Member, at base. Forks of road $0.5 \mathrm{mi}(2.4 \mathrm{~km})$ southeast of Shrader, Tazewell quadrangle (30-minute), Tazewell County, Va. Collected by Harnsberger, September 1916. See Campbell (1897) for geologic map of the area.

2020A-PC: Greenbrier Limestone, Hillsdale Member, about $25 \mathrm{ft}$ (7.5 $\mathrm{m})$ above base. Same geographic location as 2020-PC. See Girty (1923, p. 470) for faunal list and description of the locality.

2222A-PC: St. Louis Limestone, $0.75 \mathrm{mi}(1.2 \mathrm{~km})$ northeast of Hicks, probably in NE $1 / 4$ sec. 19, T. 11 S., R. 8 E., Equality quadrangle, Hardin County, Ill. Collected by Charles Butts, 1916. See Weller (1920, pl. 1) for geologic map of the area.

2222C-PC: Same as 2222A-PC.

2226-PC: St. Louis Limestone. $0.75 \mathrm{mi}(1.2 \mathrm{~km})$ north of Big Creek School, probably in $\mathrm{SE}^{1 / 4}$ sec. 21 , T. 11 S., R. 8 E., Equality quadrangle, Hardin County, Ill. Collected by Charles Butts, 1916. See Weller $(1920, \mathrm{pl} .1)$ for geologic map of the area.

2333-PC: St. Louis Limestone. Near top of divide near Allen Springs, 8 to $10 \mathrm{mi}$ (12.8 to $16 \mathrm{~km})$ northwest of Scottsville, Allen Springs 
quadrangle, Allen County, Ky. Collected by E. W. Shaw, 1917. See Moore (1963) for geologic map of the area.

3024-PC: Little Flat Formation (Mamet foraminifer Zone 14). NW11/4 sec. 13 , T. 7 S., R. 40 E., altitude $6,650 \mathrm{ft}(2,015 \mathrm{~m})$, Henry quadrangle, Caribou County, Idaho. Collected by P. V. Roundy, June 29, 1916. This locality is mapped as Brazer Limestone by Mansfield (1927, pl. 3). Megafossils in the collection indicate Zone $\mathrm{E}$ of Sando and others (1969), and microfossils are Mamet Zone 14.

3159-PC: Newman Limestone, at base. $1.5(2.4 \mathrm{~km})$ mi northeast of Cleveland, Carbo quadrangle (7 1/2-minute), Russell County, Va. Collected by Charles Butts, March 1912. See Campbell (1899) for geologic map of the area.

3282-PC: Hillsdale Member of Greenbrier Limestone, lower $50-\overline{7} 5 \mathrm{ft}$ $(15-23 \mathrm{~m})$. In low hills and flats of the "little levels" within $1 \mathrm{mi}(1.6$ $\mathrm{km}$ ) west and southwest of Mill Point, Marlintown quadrangle (15-minute), Pocahontas County, W. Va. Collected by W. A. Price and G. H. Girty, September 23, 1920. See Price (1929) for geologic map of the area and Girty (1923, p. 456) for faunal list and description of the locality. The collection contains corals, bryozoans, and brachiopods listed by Girty.

3283-PC: Hillsdale Member of Greenbrier Limestone, lower $70 \mathrm{ft}$ (21.2 $\mathrm{m})$. Limestone ledges at Mill Point in small hill (altitude $2,260-2,330 \mathrm{ft}, 685-706 \mathrm{~m}$ ) just north of residence of $\mathrm{Mr}$. Wallace, east of Stamping Creek and north of highway from Mill Point to Buckeye, Marlinton quadrangle (15-minute), Pocahontas County, W. Va. Collected by W. A. Price and G. H. Girty, September 22, 1920. See 3282-PC for further information on this locality.

3290-PC: Lodgepole Limestone, Woodhurst Member (Zone $\mathrm{C}_{1}$ of Sando and others, 1969). Near Lime Spur, probably in sec. 17, 18, 19, or 20, T. 1 N., R. 2 W., Jefferson Island quadrangle, Jefferson or Madison County, Mont. Collected by D. C. Bard. See Chelini (1965, fig. 5) for geologic map of the area. Collection contains megafossils that indicate Zone $\mathrm{C}_{1}$ of Sando and others (1969) and algae that indicate Mamet Zones 7-8.

3747C-PC: Peratrovich Formation, limestone and chert member (upper Meramecian). South shore of Shelikof Island at entrance to Soda Bay, about on parallel $55^{\circ} 15^{\prime}$, southeastern Alaska. Collected by G. H. Girty, June 9, 1918. See Armstrong (1970a, p. 29-31) for discussion.

3760-PC: Peratrovich Formation, limestone and chert member (upper Meramecian). West end of south shore of Madre de Dios Island, southeastern Alaska. Collected by G. H. Girty, June 18, 1918. See Armstrong (1970a) for discussion.

3856-PC (green label): McCloud Limestone (Lower Permian). Crest of Limestone ridge $0.5 \mathrm{mi}(0.8 \mathrm{~km})$ north of James ranch in NE 1/4 sec. 22, T. 33 N., R. 4 W., Redding quadrangle, Shasta County, Calif. Collected by J. S. Diller, July 5, 1902. The occurrence of Heterocaninia? gabbi (Meek) and Omphalotrochus whitneyi (Meek) in the collection confirm the McCloud assignment.

3858-PC (green label): McCloud Limestone (Lower Permian). $1 \mathrm{mi}$ (1.6 $\mathrm{km}$ ) northwest of Lillienthal, probably in NE 1/4 sec. 27, T. 33 N., R. 4 W., Redding quadrangle, Shasta County, Calif. Collected by Stanton and Richardson, July 8, 1902. The locality was mapped as McCloud Limestone by Diller (1906). The only other fossil in the collection is Heritschioides? sp. The locality number was erroneously given as 3859 by Hayasaka $(1936$, p. 64).

3864-PC: Float from Lodgepole Limestone, Woodhurst Member (Zone $\mathrm{C}_{1}$ of Sando and others, 1969). Unknown canyon on south side of Little Rocky Mountains, Phillips County(?), Mont. See Knechtel $(1959$, pl. 52) for geologic map of the area.

The stratigraphic level assigned to this locality is the only one in which corals of this kind occur in the Little Rocky Mountains. The canyon in which the specimen was found was said to be the one containing the powerline to Zortman, but on recent maps of the area, I can find no powerline shown in any of the canyons on the south side of the Little Rocky Mountains.
3890-PC (green label): McCloud Limestone (Lower Permian). Summit of Gray Rock Ridge northwest of road above Black Diamond mine, probably in NE $1 / 4$ sec. 5 , T. 33 N., R. 4 W., Redding quadrangle, Shasta County, Calif. Collected by Storrs and Washburne. See Diller (1906) for geologic map of the locality. Brachiopods in the collection indicate a Permian age. The locality number was erroneously given as 3896 by Hayasaka (1936, p. 64).

3946-PC (green label): Probably from St. Louis Limestone of the Mississippi Valley region. The specimen was said to come from the Santa Anra Mountains, Orange County, Calif., which is an area of post-Paleozoic rocks. It is a museum specimen attributed to Dr. Steven Bowen of Los Angeles, Calif. The specimen has all the characteristics of corals that are abundant in the St. Louis Limestone of the Mississippi Valley region. The locality number was erroneously given as 3446 by Hayasaka (1936, p. 61 ).

4801H-FC (green label): Little Flat Formation (Member B of Brazer Limestone of Mullens and Izett, 1964). Probably in sec. 30, T. 10 N., R. 2 E., Paradise quadrangle, Cache County, Utah. Collected by E. M. Kindle, August 12, 1907.

This specimen was erroneously attributed by Hayasaka (1936, p. 66 ) to USGS Mesozoic loc. $4801 \mathrm{H}$, which is from the Monte de Oro Formation (Upper Jurassic), "western portion of the Oroville plant beds, north side of Feather River, 3 to 4 mi above Oroville, California." Foraminifera in the specimen are Mamet Zones 13-15 (probably 14) and are Western United States species.

5892-PC: Madison Limestone (Zone $\mathrm{C}_{1}$ of Sando and others, 1969). Ridge west of Holiday Park, probably in sec. 26,34 , or 35 , T. 1 N., R. 8 E., Coalville quadrangle, Summit County, Utah. The collection contains megafossils that indicate Zone $\mathrm{C}_{1}$ of Sando and others (1969)

5893-PC: Little Flat Formation (Member B of the Brazer Limestone of Mullens and Izett, 1964). Probably in sec. 5 or 6, T. 9 N., R. 2 E., Paradise Canyon, Paradise quadrangle, Cache County, Utah. Collected by E. Finch. The collection contains Faberophyllum sp. (Zone F of Sando and others, 1969) and foraminifers of Mamet Zone 14.

5894-PC: Float probably from lower part of the Mission Canyon Limestone (Zone $\mathrm{C}_{2}$ of Sando and others, 1969). Crest of ridge east of Old Baldy at altitude of about $9,000 \mathrm{ft}(2,727 \mathrm{~m})$, probably in sec. 26 or 27, T. 7 S., R. 3 W., Varney quadrangle, Madison County, Mont. Collected by R. W. Richards. See Hadley (1969) for geologic map of the area.

7130B-PC: Cobble in river wash derived probably from the Alapah Limestone. Along Hulahula River, Mount Michelson quadrangle, northeastern Alaska. Collected by E. de K. Leffingwell, February 1908.

7452-PC (green label): "Wells" Formation (this may actually be a Mississippian unit related to the Humbug Formation). South end of Cokeville Butte, just west of phosphate mine $1.5 \mathrm{mi}(2.4 \mathrm{~km})$ northeast of Cokeville, probably in NW1/4 sec. 4, T. 24 N., R. 119 W., Cokeville quadrangle, Lincoln County, Wyo. Collected by G. H. Girty, July 22, 1909. Foraminifers in the specimen are Mamet Zones 18-20.

LOCALITY DATA FOR USNM SPECIMENS NOT HAYASAKA TYPES

\begin{tabular}{|c|c|c|}
\hline USNM No. & Stratigraphic unit & Locality \\
\hline \multicolumn{3}{|c|}{ Acrocyathus floriformis floriformis } \\
\hline $\begin{array}{l}13669 \\
71646\end{array}$ & $\begin{array}{l}\text { St. Louis Limestone } \\
\text { St. Louis Limestone } \\
\text { [equivalent]. }\end{array}$ & $\begin{array}{l}\text { Mt. Pleasant Iowa } \\
\text { Rainbow Mountain, Ala. }\end{array}$ \\
\hline 216206 & St. Louis Limestone & Livingston, Tenn. \\
\hline \multicolumn{3}{|c|}{ Acrocyathus floriformis hemisphaericus } \\
\hline $\begin{array}{l}8211 \\
98102\end{array}$ & $\begin{array}{l}\text { St. Louis Limestone } \\
\text { St. Louis Limestone } \\
\text { [equivalent]. }\end{array}$ & $\begin{array}{l}\text { Monroe County, Ind. } \\
1.25 \mathrm{mi}(2 \mathrm{~km}) \text { north of } \\
\text { Cleveland, Va. }\end{array}$ \\
\hline
\end{tabular}


LOCALITY DATA FOR USNM SPECIMENS NOT HAYASAKA TYPES - Continued

\begin{tabular}{|c|c|}
\hline \multirow[t]{2}{*}{ USNM No. } & Stratigraphic unit \\
\hline & Acrocyathus floriformis \\
\hline 756 & St. Louis Limestone _-_-_- \\
\hline $\begin{array}{l}3779 \\
15526\end{array}$ & Lower Carboniferous \\
\hline 17071 & do \\
\hline 17848 & St. Louis Limestone \\
\hline 37466 & -_-_do \\
\hline 39654 & ---- do _-_-_-_- \\
\hline 42695 & -__do_ \\
\hline 42766 & do_. \\
\hline 135092 & -_-_do \\
\hline 135094 & -_-_do__ \\
\hline 135096 & _-_do_-_-_-_-_-_-_-_- \\
\hline 135097 & do_-_- \\
\hline 135172 & - do \\
\hline 135173 & -_-_do_-_-_- \\
\hline
\end{tabular}

135174

135177

135179

135300

135301

135302

136704

166604

166605

216198

216199

216200

216202

216203

216204

216205

216207

216208

216210

216211

216212

Greenbrier Limestone

216214 do

Locality

species undet.

St. Francisville, Mo.

Sugar Creek, Iowa

Near Prairie du Rocher, Ill. Clear Springs, Harrison

County, Ind.

Kentucky

St. Louis, Mo.

Elizabethtown, Ky.

Eddyville, Ky.

Clarksville, Tenn.

Monroe County, Ind.

Weaver's Branch of Des

Moines River, near

St. Francisville, Clark

County, Mo.

Livingston, Tenn.

Do.

Do.

Hillside north of South

Fork of Holston River, $5 \mathrm{mi}(8 \mathrm{~km})$ north of Kingsport, Tenn.

Mississippian

St. Louis Limestone -_-..do

Mississippian -_-_do

St. Louis Limestone Mississippian

St. Louis Limestone --_-

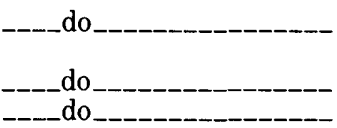

Mississippian do

St. Louis Limestone

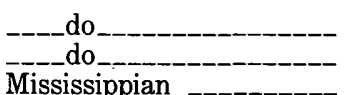

Mississippian

-....do

\begin{tabular}{|c|c|}
\hline & Acrocyathus $p$ \\
\hline 841 & St. Louis Limestone \\
\hline 4587 & Mississippian _._._. \\
\hline 37469 & St. Louis Limestone \\
\hline 37470 & Mississippian -_-_-_-_-_ \\
\hline 37471 & - \\
\hline 39655 & St. Louis Limestone \\
\hline 42667 & -_-_do_____ \\
\hline $\begin{array}{l}42705 \\
42714\end{array}$ & $-{ }_{-} \mathrm{do}_{-}$ \\
\hline
\end{tabular}

Millpoint, Pocahontas County, W. Va.

Iowa

Horse and Muddy Creeks, Dade County, Mo.

Elgin, Ill

Caney Fork River, Dekalb

County, Tenn.

Livingston, Tenn. Do.

Franklin, Ky

$$
\text { Do. }
$$

Hill Post Office,

Marshall, County, Ala.

River bluff $1 \mathrm{mi}(1.6 \mathrm{~km})$ south of Maeystown, Ill. Do.

Rock Creek, Hancock County, Ill.

Bloomington, Ind. County, Ky.

$2 \mathrm{mi}(3.2 \mathrm{~km})$ west of Ste. Genevieve, Mo.

Livingston, Tenn. Do.

Near Forbuss, Fentress County, Tenn.

About $1 \mathrm{mi}(1.6 \mathrm{~km})$ east of Little Crab, Standingstone quadrangle Tennessee

$0.5 \mathrm{mi}(0.8 \mathrm{~km})$ southeast of Shrader, Pounding Mill quadrangle, Virginia Millpoint, Pocahontas County, W. Va.

\section{iferus}

Hardin County, Ill. Gallatin County, Ill. Marion, $\mathrm{Ky}$.

Saginaw Bay, Mich. Belleview, Mich.

Elizabethtown, Ky.

Eddyville, $\mathrm{Ky}$. Do.

Clarksville, Tenn.
$1 \mathrm{mi}(1.6 \mathrm{~km})$ west of Red

Slick Rock Creek, Barren
LOCALITY DATA FOR USNM SPECIMENS NOT HAYASAKA TYPES-Continued

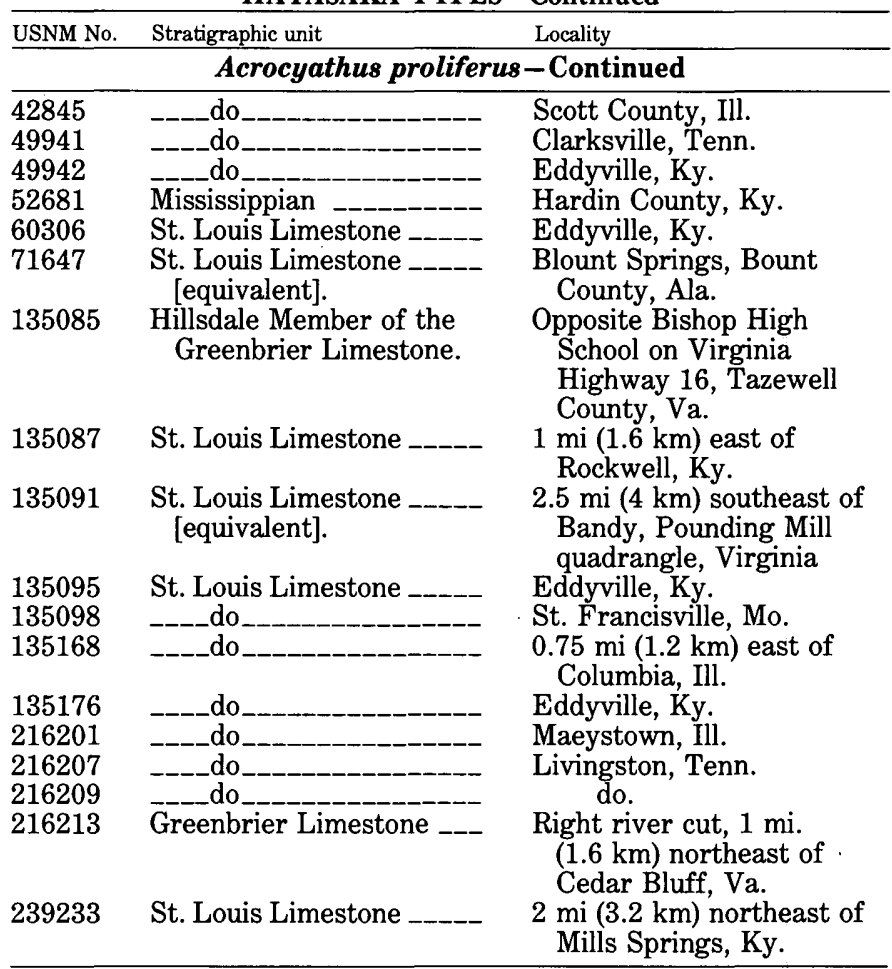

\section{REFERENCES CITED}

Allen, A. T., Jr., and Lester, J. G., 1954, Contributions to the paleontology of northwest Georgia: Georgia Geological Survey Bulletin 62,166 p., 42 pls.

Armstrong, A. K., 1962, Stratigraphy and paleontology of the Mississippian System in southwestern New Mexico and adjacent southeastern Arizona: New Mexico Bureau of Mines and Mineral Resources Memoir 8, 99 p., 12 pls., 41 figs.

1970a, Mississippian rugose corals, Peratrovich Formation, west coast, Prince of Wales Island, southeastern Alaska: U.S. Geological Survey Professional Paper 534, 44 p., 13 pls., 30 figs. $-1970 \mathrm{~b}$, Carbonate facies and the lithostrotionoid corals of the Mississippian Kogruk Formation, DeLong Mountains, northwestern Alaska: U.S. Geological Survey Professional Paper 664, 38 p., 37 figs., 14 pls.

1972a, Biostratigraphy of Mississippian lithostrotionoid corals, Lisburne Group, arctic Alaska: U.S. Geological Survey Professional Paper 743-A, 28 p., 9 pls., 25 figs.

1972b, Pennsylvanian carbonates, paleoecology, and rugose colonial corals, north flank, eastern Brooks Range, arctic Alaska: U.S. Geological Survey Professional Paper 747, 21 p., 8 pls., 16 figs.

Bamber, E. W., 1961, Mississippian corals from northeastern British Columbia, Canada: Princeton, N.J., Princeton University, Ph.D. thesis, 199 p., 14 pls., 1 fig.

1966, Type lithostrotionid corals from the Mississippian of western Canada: Canada Geological Survey Bulletin 135, 28 p., 4 pls.

Bamber, E. W., and Macqueen, R. W., 1979, Upper Carboniferous and Permian stratigraphy of the Monkman Pass and southern Pine Pass areas, northeastern British Columbia: Canada Geological Survey Bulletin 301,27 p., 40 figs. 
Barrois, Charles, 1882, Récherches sur les terrains anciens des Asturies et de la Galice: Société Géologique du Nord Mémoire, v. 2, no. 1, 630 p., 20 pls.

Bassler, R. S., 1950, Faunal lists and descriptions of Paleozoic corals: Geological Society of America Memoir 44, 315 p., 20 pls.

Bolkhovitinova, M. A., 1915, O Kamennougol'nykh korallakh i mshannakh Moskovskoi gubernii [On. Carboniferous corals and Bryozoa of Moscow province]: Obshchestvo Lyubitelei Estestvoznaniya Antropologii i Etnografii, Moscow, Geologicheskoe Otdelenie Zapiski, v. 3, p. 61-81, pls. 5, 6.

Boule, Marcellin, and others, 1906, 1907, Types du Prodrome de paléontologie stratigraphique universelle: Annales de Paléontologie, v. 1, pl. 6 (1906); v. 2, p. 89-96, pls. 7, 8 (1907).

-1923, Types du Prodrome de paléontologie stratigraphique universelle d'Alcide d'Orbigny: Paris, v. 1, 203 p., 21 figs., 34 pls.

Bowsher, A. L., 1961, The stratigraphic occurrence of some Lower Mississippian corals from New Mexico and Missouri: Journal of Paleontology, v. 35, no. 5, p. 955-962, pls. 109, 110, 3 figs.

Brindle, J. E., 1960, Mississippian megafaunas in southeastern Saskatchewan: Saskatchewan Department of Mineral Resources Report 45, 107 p., 29 pls., 4 figs.

Bul'vanker, E. Z., Vasilyuk, N. P., Zheltongova, V. A., Zhizhina, M. S., Nikolaeva, T. V., Spasskiy, N. Ya., and Shchukina, V. Ya., 1960, Novye predstaviteli chetyrekhluchevykh korallov SSSR [New representatives of tetraradiate corals in the USSR], in Markovskiy, B. P., ed., Novye vidy drevnikh rasteniy i bespozvonochnykh SSSR [New species of ancient plants and invertebrates from USSR]: Moscow, Vsesoyuznyy Nauchno-Issledovatel'skiy Geologicheskiy Institut (VSEGEI), p. 220-254, pls. 44-61.

Butts, Charles, 1917, Descriptions and correlation of theMississippian formations of western Kentucky: Frankfort, Ky., Kentucky Geological Survey, 119 p.

1926, Geology of Alabama-The Paleozoic rocks: Alabama Geological Survey Special Report 14, p. 41-230, pls. 3-76.

1941, Geology of the Appalachian Valley in Virginia-Pt. 2, Fossil plates and descriptions: Virginia Geological Survey Bulletin 52 , pt. 2, 271 p., 135 pls.

Campbell, M. R., 1897, Description of the Tazewell quadrangle [Va.-W. Va.]: U.S. Geological Survey Geologic Atlas, Folio 44, 6 p., maps. 1899, Description of the Bristol quadrangle [Va.-Tenn.]: U.S. Geological Survey Geologic Atlas, Folio 59, 8 p., maps.

Carlson, K. J., 1964, Corals of the Gilmore City Limestone (Mississippian) of Iowa: Journal of Paleontology, v. 38, no. 4, p. 662-666, pls. $109,110$.

Castelnau, Francis de, 1843, Essai sur le système Silurien de l'Amérique septentrionale: Paris, 56 p., 27 pls.

Chapman, E. J., 1893, On the corals and coralliform types of Palaeozoic strata: Royal Society of Canada Proceedings and Transactions, v. 10 , sec. 4 , p. 39-48.

Chelini, J. M., 1965, Limestone, dolomite, and travertine in Montana: Montana Bureau of Mines and Geology Bulletin 44, 53 p., 15 figs.

Chi, Y. S., 1931, Weiningian (Middle Carboniferous) corals of China: Palaeontologica Sinica, ser. B., v. 12, no. 5, 70 p., 5 pls.

Cotton, Geoffrey, 1973, The rugose coral genera: Amsterdam, Elsevier, $358 \mathrm{p}$.

1974, The rugose coral genera, Supplement 1: Kidderminster, England, privately published, $35 \mathrm{p}$.

Crickmay, C. H., 1955, The Minnewanka section of the Mississippian [Alberta]: Calgary, Alberta, Imperial Oil, Ltd., 14 p., 2 pls., 3 charts. (Reprinted with emendations, 1961.)

Davis, D. E., 1956, A taxonomic study of the Mississippian corals of central Utah: Brigham Young University Research Studies, Geology Series, v. 3, no. 5, 49 p., 4 pls., 3 figs.

Degtyarev, D.D., 1973, Novyye vidy korallov Zapadnoural'skogo (uglenoskogo) gorizonta Urala [New species of corals from the
Zapadnouralsk (coral-bearing) horizon of the Urals]: Akademiya Nauk SSSR, Uralskiy Nauchnyi Tsentr, Instituta Geologii i Geokhimii Trudy, v. 82 , p. 191-205, 5 pls.

Diller, J. S., 1906, Description of the Redding quadrangle [Calif.]: U.S. Geological Survey Geologic Atlas, Folio 138, 14 p., maps.

Dobrolyubova, T. A., 1935a, Opredelitel' kolonial'nykh korallov Rugosa Srednego Karbona Podmoskovnogo Basseina [Determinant of Middle Carboniferous colonial Rugosa corals of the Moscow Basin]: Moscow, Vsesoyuznyy Nauchno-Issledovatel'skiy Institut Mineral'nogo Syriya, $14 \mathrm{p}$.

-1935b, Kolonial'nye korally Rugosa Srednego Karbona Pod moskovnogo basseina [Rugosa colonial corals in the Middle Carboniferous of the Moscow basin]: Vsesoyuznyy NauchnoIssledovatel'skiy Institut Mineral'nogo Syriya Trudy, no. 81, 46 p., 14 pls. (English summary.)

1936a, Korally Verkhnego Karbona zapadnogo sklona srednego Urala i ikh stratigraficheskoe znachenie [Corals of the Upper Carboniferous of the western slope of the middle Urals and their stratigraphic importance]: Vsesoyuznyy Nauchno-Issledovatel'skiy Institut Mineral'nogo Syriya Trudy, no. 103, 68 p., 37 pls. (English summary.)

-1936b, Korally Rugosa srednego i verkhnego Karbona i nizhney permi Severnogo Urala [Rugosa corals of the middle and upper Carboniferous and Lower Permian of the north Urals]: Akademiya Nauk SSSR, Polyarnaya Komissiya Trudy, no. 28, p. 77-158, 81 figs. (English summary.)

1952, Formoobrazovanie u Nizhnekammenougol'nykh korallov Lithostrotion i Lonsdaleia v svete Michurinskogo ucheniya [Morphologic development of the lower Carboniferous corals Lithostrotion and Lonsdaleia in view of the Michurin school]: Akademiya Nauk SSSR, Izvestiya, Seriya Biologicheskaya, no. 6, p. 95-110, 8 figs.

Dobrolyubova, T. A., and Kabakovich, N. V., 1962, Tip Coelenterata. Kishechnopolostnye [Phylum Coelenterata], in Khalfin, L. L., ed., Biostratigrafiya Paleozoya Sayano-Altaiskoy gornoy oblasti, Tom 3, Verkhniy Paleozoy [Paleozoic biostratigraphy of the SayanoAltai mountainous region, v. 3, Upper Paleozoic]: Sibirskii Nauchno-Issledovatel'skiy Institut Geologii, Geofiziki, i Mineral'nogo Syriya (SNIIGGIMS), Trudy, no. 21, p. 115-124, pls. $\mathrm{C}-3$ to $\mathrm{C}-5$.

1.966, Chetyrekhluchevye korally Nizhnego Karbona Kuznetskoy kotloviny [Tetracorals from the lower Carboniferous of the Kuznetsk basin], in Dobrolyubova, T. A., Kabakovich, N. V., and Sayutina, T. A., Korally Niznego Karbona Kuznetskoy kotloviny [Corals from the lower Carboniferous of the Kuznetsk basin]: Akademiya Nauk SSSR, Paleontologicheskiy Institut Trudy, v. 11., p. 5-198, pls. 1-36, figs. 1-16.

Easton, W. H., 1944, Corals from the Chouteau and related formations of the Mississippi Valley region: Illinois State Geological Survey Report of Investigations 97,93 p., 17 pls.

1958, Mississippian corals from northwestern Sonora, Mexico, in Easton, W. H., and others, Mississippian fauna in northwestern Sonora, Mexico: Smithsonian Miscellaneous Collections, v. 119, no. 3 , p. 1-40, 2 pls., 3 figs.

1960, Permian corals from Nevada and California: Journal of Paleontology, v. 34 , no. 3 , p. 570-583, 18 figs.

1963, Additional comments on species of Lithostrotionella: Journal of Paleontology, v. 37, no. 1, p. 297-298.

-1973, On the tetracorals Acrocyathus and Lithostrotionella and their septal morphology: Journal of Paleontology, v. 47, no. 1, p. 121-135, $1 \mathrm{pl}$.

Easton, W. H., and Gutschick, R. C., 1953, Corals from the Redwall Limestone (Mississippian) of Arizona: Southern California Academy of Science Bulletin, v. 52, pt. 1, p. 1-27, 3 pls., 2 figs. 
Eichwald, Eduard von, 1861, Paleontologiya Rossii. Drevniy period: St. Petersburg, $520 \mathrm{p}$.

Etheridge, Robert, Jr., 1900, Corals from the Coral Limestone of Lion Creek, Stanwell, near Rockhampton: Queensland Geological Survey Bulletin 12, p. 5-24, pls. 1, 2.

Fedorowski, J., and Gorianov, V. B., 1973, Redescription of tetracorals described by E. Eichwald in "Palaeontology of Russia": Acta Palaeontologica Polonica, v. 18 , no. 1, p. $3-70,13$ pls., 20 figs.

Fenneman, N. M., 1911, Geology and mineral resources of the St. Louis quadrangle, Missouri-Illinois: U.S. Geological Survey Bulletin 438, 73 p., 6 pls., 1 fig.

Fischer von Waldheim, Gotthelf, 1830, Oryctographie du gouvernement du Moscou: Moscow, A. Semen, 202 p., 62 pls. (2d ed., 1837).

Flügel, H. W., 1970, Bibliographie der paläozoischen Anthozoa (Rugosa, Heterocorallia, Tabulata, Heliolitida, Trachypsammiacea). Pt. 2, Index zur Bibliographie: Vienna, Osterreichische Akademie der Wissenschaften, $323 \mathrm{p}$.

Fomichev, V. D., 1931, Novye dannye o Nizhne-Kammenougol'nykh korallakh Kuznetskogo basseina [New data on Lower Carboniferous corals of the Kuznetsk basin]: Russia, GeologoRazvedochnoe Ob'edeneniya Trudy, no. 49, 80 p., 2 pls. -1939, Tip Kishechnopolosnye Coelenterata [Phylum Coelenterata], in Gorskiy, I. I., Atlas rukovodyashchikh form iskopaemoy fauny SSSR, tom 5, Sredniy i Verkhniy otdely Kamennougol'noy Sistemy [Atlas of the leading forms of the fossil faunas of the USSR, v. 5, Middle and upper Carboniferous]: Tsentral'nyy Nauchno-Issledovatel'skiy Geologo-Razvedochnyy Institut (TSNIGRI), p. 50-64, pls. 6-11, figs. 10-12.

_ 1953, Korally Rugosa i stratigrafiya sredni- i verkhnekamennougolnykh i permskikh otlozhenii Donetskogo basseina [Rugose corals and stratigraphy of middle and upper Carboniferous and Permian deposits of Donetz basin]: Moscow, Vsesoyuznyy Nauchno-Issledovatel'skiy Geologicheskiy Institut (VSEGEI) Trudy, 622 p. (incl. pls., under separate cover, and geol. map).

1955, Tip Coelenterata. Kishechnopolostnye [Phylum Coelenterata], in Khalfin, L. L., ed., Atlas rukovodyashchikh form iskopaemykh fauny i flory zapadnoy Sibiri [Atlas of the leading forms of fossil fauna and flora from western Siberia]: ZapadnoSibiriskoe Geologicheskoe Upravlenie-Tomsky Politekhnicheskiy Institut, Moscow, Gosudarstvennoe Nauchno-Tekhnicheskoe Izdatel'stvo Literatur po Geologi i Okhvane Nedr, v. 1, p. 298-305, pls. 79,80 .

Fromentel, Édouard de, 1861, Introduction à l'étude des polypiers

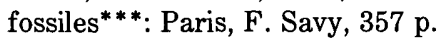

Gabounia, K. E., 1919, Materialy k izucheniyu fauny korallov iz Nizhne-kamennougel'nykh otlozheniy okolo derevin Royki po $r$. Tomi [Contribution to the study of the coral fauna from the Lower Carboniferous deposits around the village of Royka on the Tom River]: Russia, Geologicheskii Komitet, Zapadno-Sibirskoe Otdelenie Izvestiya, v. 1 , no. 3,48 p., 4 pls.

Garwood, E. J., 1912, The lower Carboniferous succession in the North-west of England: Geological Society of London Quarterly Journal, v. 68 , p. $449-572$, pls. $44-56$.

Girty, G. H., 1923, Observations on the faunas of the Greenbrier limestone and adjacent rocks: West Virginia Geological Survey, Tucker County [Report], p. 450-488.

Gorskiy, I. I., 1935, Nekotorye Coelenterata iz nizhnekamennougol'nykh otlozheniy Novoi Zemli [Some Coelenterata from the lower Carboniferous beds of Novaya Zemlya]: Leningrad, Vsesoyuznyy Arkticheskii Institut Trudy, v. 28, 128 p., 12 pls., 27 figs. (English summary.)

1938, Kammenougol'nye korally Novoi Zemli [Carboniferous corals from Novaya Zemlya], in Nalivkin, D. V., ed., Paleontologiya Sovetskoy Arktiki [Paleontology of the Soviet Arctic]:
Leningrad, Vsesoyuznyy Arkticheskii Institut Trudy, v. 93, pt. 2, 221 p., 16 pls., 82 figs. (English summary.)

Groot, G. E. de, 1964, Rugose corals from the Carboniferous of northern Palencia (Spain): Leidse Geologische Mededalingen, v. 29, p. 1-123, pls. 1-26, figs. 1-39. (Preprint 1963.)

Grosch, Paul, 1909, Phylogenetische Korallenstudien (Die Axophylliden): Deutsche Geologische Gesellschaft Zeitschrift, v. 61, no. 1 , p. 1-34, pl. 1,11 figs.

Grote, A. R., 1883, Introduction to a study of North American Noctuidae: American Philosophical Society Proceedings, v. 21, p. 134-176.

Gualtieri, J. L., 1968, Geologic map of the Wildie quadrangle, Garrard and Rockcastle Counties, Kentucky: U.S. Geological Survey Geologic Quadrangle Map GQ-684, scale 1:24,000.

Hadley, J. B., 1969, Geologic map of the Varney quadrangle, Madison County, Montana: U.S. Geological Survey Geologic Quadrangle Map GQ-814, scale 1:62,500.

Hall, James, and Whitney, J. D., 1858, Report on the geological survey of the State of Iowa, v. 1, pt. 2, Paleontology: [Albany, N.Y.], p. 473-724.

Hayasaka, Ichirô, 1936, On some North American species of Lithostrotionella: Taihoku Imperial University Memoir, v. 13, no. 5, Geology, no. 12 , p. $47-73,7$ pls.

Heritsch, Franz, 1937, Lithostrotionella stylaxis Trautschold aus der arabischen Wüste: Naturwissenschaftlicher Verein für Steiermark, Mitteilungen, v. 74, p. 164-165, 1 fig.

1939, Die Korallen des Jungpaläozoikums von Spitzbergen: Arkiv für Zoologie, v 31A, heft 3, no. 16, 138 p., 21 pls.

1940, Korallen aus dem Karbon von Jugoslavien: Yugoslavia Service Géologique Royaume Bulletin, v. 8, p. 69-78, pl. 2.

Hill, Dorothy, 1938, A monograph on the Carboniferous rugose corals of Scotland, pt. 1: London, Palaeontographical Society, p. 1-78.

1940, A monograph on the Carboniferous rugose corals of Scotland, pt. 3: London, Palaeontographical Society, p. 115-204, pls. 6-11.

1956, Rugosa, in Moore, R. C., ed., Treatise on invertebrate paleontology, pt. F., Coelenterata: New York and Lawrence, Kans., Geological Society of America and University of Kansas Press, p. F233-F324.

Hinds, Henry, 1919, Description of the Colchester and Macomb quadrangles, Illinois: U.S. Geological Survey Geologic Atlas, Folio 208, 14 p., 14 figs., 4 maps.

Holtedahl, Olaf, 1913, Zur Kenntnis der Karbonablagerungen des westlichen Spitzbergens. II. Allgemeine stratigraphische und tecktonische Beobachtungen: Norske Videnskaps-Akademi Skrifter, Matematisk-naturvidenskapelig Klasse, 1912, no. 23, 91 p., 11 pls., 25 figs.

Huang, T. K., 1932, Permian corals of southern China: Palaeontologia Sinica, ser. B., v. 8, fasc. 2, 163 p.

Ivanovskiy, A. B., 1967, Etyudy o Rannekamennougol'nykh Rugozakh [Studies of Early Carboniferous Rugosa]: Moscow, Akademiya Nauk SSSR, Sibirskoye Otdeleniye, Institut Geologii i Geofiziki, 92 p., 22 pls., 22 figs.

-1975, Rugozy [Rugosa]: Moscow, Izdatel'stvo "Nauka", $121 \mathrm{p}$.

Jenney, W. P., 1894, The lead and zinc deposits of the Mississippi Valley: American Institute of Mining Engineers Transactions, v. 22 , p. $171-225,621-646$.

Jones, O. A., 1929, On the coral genera Endophyllum Edwards and Haime and Spongophyllum Edwards and Haime: Geological Magazine, v. 66 , no. 776 , p. $84-91$.

Kato, Makoto, 1963, Fine skeletal structures in Rugosa: Hokkaido University Faculty of Science Journal, ser. 4, v. 11, no. 4, p. 571-630, 3 pls., 19 figs.

1966, Note on some Carboniferous coral genera: Clisaxophyllum, Clisiophyllum (Neoclisiophyllum), Zaphrentoides, 
Stylidophyllum, and Actinocyathus: Japanese Journal of Geology and Geography, v. 37, nos. 2-4, p. 93-104.

Kelly, W. A., 1942, Lithostrotiontidae in the Rocky Mountains: Journal of Paleontology, v. 16, no. 3, p. 351-361, pls. 50, 51, 1 fig.

Keyes, C. R., 1894, Paleontology of Missouri, Pt. 1: Missouri Geological Survey, v. 4, 271 p., 32 pls.

Knechtel, M. M., 1959, Stratigraphy of the Little Rocky Mountains and encircling foothills, Montana: U.S. Geological Survey Bulletin $1072-\mathrm{N}$, p. $723-752$, pl. 52, 53, figs. $32,33$.

Kolosváry, Gabor, 1951, Magyarorzág permokarbon koralljai [PermoCarboniferous corals of Hungary]: Földtani Közlöny, v. 81, nos. 1-3, 4-6, p. 4-52, 171-185, pls. 1-19, 6 figs. (English summary.)

Koninck, L. G. de, 1872, Nouvelles recherches sur les animaux fossiles du terrain Carbonifere de la Belgique ***: Brussels, F. Hayez, 178 p.

Kozyreva, T. A., 1974, Novye korally roda Petalaxis (Rugosa) iz Bashkirskogo yarusa Voronezhskoy anteklizy [New corals of the genus Petalaxis (Rugosa) from the Bashkirian stage of the Voronezh anteclise]: Paleontologicheskiy Zhurnal, 1974, no. 3, p. 23-31, 2 pls.

Lambe, L. M., 1899, On some species of Canadian Paleozoic corals: Ottawa Naturalist, v. 12 , p. 217-226, 237-258.

1901, A revision of the genera and species of Canadian Palaeozoic corals; the Madreporaria Aporosa and the Madreporaria Rugosa: Canada Geological Survey, Contributions to Canadian Palaeontology, v. 4, pt. 2, p. 97-197.

Lang, W. D., Smith, Stanley, and Thomas, H. D., 1940, Index of Palaeozoic coral genera: London, British Museum, $231 \mathrm{p}$.

Langenheim, R. L., Jr., and others, 1960, Preliminary report on the geology of the Ely No. 3 quadrangle, White Pine County, Nevada, in Boettcher, J. W., and Sloan, W. W., eds., Guidebook to the geology of east central Nevada-Intermountain Association of Petroleum Geologists, 11th Annual Field Conference, 1960: Salt Lake City, Utah Geological and Mineralogical Survey, p. 148-156.

Lecompte, Marius, 1952, Madréporaires paléozoiques, in Pivetau, Jean, Traité de paléontologie, tome 1: Paris, Masson, p. 419-538, 75 figs.

Lindström, Gustaf, 1884, Index to the generic names applied to the corals of the Palaeozoic formations: Svenska VetenskapsAkademiens Handlingar, Bihang, v. 8 (1883-1884), no. 9, 14 p. [1883].

Lisitsyn, K. I., 1925, Podrazdeleniya Nizhnego Karbona i ikh korallavo-brakhiopodovaya fauna [Subdivisions of the Lower Carboniferous and their coral-brachiopod fauna]: Donskoi Politekhnicheskii Institut Izvestiya, v. 9, p. 54-68, 2 pls.

Lo, C. T., and Chao, C. M., 1962, [Lower Carboniferous tetracorals of the Chilien-shan (Tsinghai) district], in [Geology of Chilien-shan Mountains]: Peking, v. 4, no. 3, p. 111-199, pls. 1-30. (In Chinese.)

Mallock, J. R., 1929, Notes on Australian Diptera XX: Linnean Society of New South Wales Proceedings, v. 54, p. 283-343.

Mansfield, G. R., 1927, Geography, geology, and mineral resources of part of southeastern Idaho: U.S. Geological Survey Professional Paper 152, 409 p., 46 figs., 63 pls.

Martin, William, 1809, Petrificata derbiensia; or Figures and descriptions of petrifactions collected in Derbyshire: Wigan, D. Lyon, 102 p., 52 pls.

McCalley, Henry, 1896, Report on the valley regions of Alabama (Paleozoic strata). Part 1, on the Tennessee Valley region: Montgomery, Ala., Alabama Geological Survey, 436 p., 9 pls.

McCoy, Frederick, 1849, On some new genera and species of Palaeozoic corals and Foraminifera: Annals and Magazine of Natural History, 2d ser., v. 3, p. 1-20, 119-136.

McCutcheon, V. A., and Wilson, E. C., 1961, Ptolemaia, a new colonial coral from the Lower Permian of eastern Nevada and western Russia: Journal of Paleontology, v. 35, no. 5, p. 1020-1028, 1 pl., 3 figs.
1963, Kleopatrina, new name for Ptolemaia McCutcheon and Wilson: Journal of Paleontology, v. 37, no. 1, p. 299.

McLaren, D. J., and Sutherland, P. K., 1949, Lithostrotion from northeast British Columbia and its bearing on the genomorph concept: Journal of Paleontology, v. 23, no. 6, p. 625-634, pl. 103, 4 figs.

Meek, F. B., 1864, Description of the Carboniferous fossils: California Geological Survey, Palaeontology, v. 1, sec. 1, p. 1-16, pls. 1, 2.

Merriam, C. W., 1942, Carboniferous and Permian corals from central Oregon: Journal of Paleontology, v. 16, no. 3, p. 372-381, pls. $54-57$.

Milne-Edwards, H. M., 1860, Histoire naturelle des coralliaires, ou polypes proprement dits, V. 3: Paris, Roret, $560 \mathrm{p}$.

Milne-Edwards, H. M., and Haime, Jules, 1850, 1852, A monograph of the British fossil corals, Pts. 1 and 3: London, Palaeontographical Society, Pt. 1, p. 1-71, pls. 1-11; Pt. 3, p. 147-210, pls. 31-46.

[1851?] Monographie des polypiers fossiles des terrains palaeozoiques: Paris, Gide et J. Baudry, 502 p., 14 pls. (Muséum d'Histoire Naturelle [Paris], Archives, v. 5.)

Minato, Masao, 1955, Japanese Carboniferous and Permian corals: Hokkaido University, Faculty of Science Journal, ser. 4, Geology and Mineralogy, v. 9, no. 2, 202 p., 43 pls., 24 figs. (Also pub. as: Hokkaido University, Faculty of Science, Dept. of Geology and Mineralogy Contribution 540.)

Minato, Masa.o, and Kato, Makoto, 1965, Durhaminidae (tetracoral): Hokkaido University, Faculty of Science Journal, ser. 4, Geology and Mineralogy, v. 13, no. 1, p. 13-86, pls. 1-5, figs. 1-24.

1974, Upper Carboniferous corals from the Nagaiwa Series, southern Kitakami Mountains, N. E. Japan: Hokkaido University, Faculty of Science Journal, ser. 4, Geology and Mineralogy, v. 16, nos. 2-3, p. 43-119, 16 pls., 7 figs.

Moore, S. L., 1963, Geology of the Allen Springs quadrangle, Kentucky: U.S. Geological Survey Geologic Quadrangle Map GQ-285, scale $1: 24,000$.

Morse, W. C., 1930, Paleozoic rocks: Mississippi Geological Survey Bulletin 23, $212 \mathrm{p}$.

Mullens, T. E., and Izett, G. A., 1964, Geology of the Paradise quadrangle, Cache County, Utah: U.S. Geological Survey Bulletin 1181-S, 32 p., 1 pl., 1 fig.

Nations, J. D., 1963, Evidence for a Morrowan age for the Black Prince Limestone of southeastern Arizona: Journal of Paleontology, v. 37 , no. 6 , p. $1252-1264$, pls. $175-177,5$ figs.

Nelson, S. J., 1960, Mississippian lithostrotionid zones of the southern Canadian Rocky Mountains: Journal of Paleontology, v. 34, no. 1, p. 107-126, pls. 21-25, 3 figs.

1961, Reference fossils of Canada-Pt. 2, Mississippian faunas of western Canada: Geological Association of Canada Special Paper 2, 39 p., 29 pls., 7 figs.

1962, Lithostrotionella jasperensis and synonyms: Journal of Paleontology, v. 36, no. 1, p. 170-171.

Nicholson, H. A., and Thomson, J., 1876, Descriptions of some new or imperfectly understood forms of Palaeozoic corals [abs.]: Royal Society of Edinburgh Proceedings 1875-1876, v. 9, no. 95, p. 149-150.

Onoprienko, Yu. I., 1970, K voprosu ob obshcheme roda Lithostrotionella Yabe et Hayasaka, 1915 [On the scope of the genus Lithostrotionella Yabe and Hayasaka, 1915]: Severo-vostochnoe Geologicheskoe Upravlenie (Magadan), Informatsionnoe Soobshchenie, no. 5, p. 3-6.

1976, Rannekamennougol'nye kolonial'nye rugozy severovostoka SSSR [Early Carboniferous colonial Rugosa from the northeast U.S.S.R], in Petrashevskaya, V., ed., Morfologiya i systematika iskapaemykh bespozvonochnykh Dal'nego vostoka: Akademiya Nauk SSSR, Dal'nevostochnyy Nauchnyy Tsentr, Biologo-pochvennyy Institut Trudy, v. 42, no. 145, p. 5-34. 
Orbigny, A. D., d', 1849a, Note sur des polypiers fossiles: Paris, Victor Masson, $12 \mathrm{p}$.

$-1849 \mathrm{~b}-1852$, Prodrome de paléontologie stratigraphique universelle des animaux mollusques \& rayonnés, faisant suite au Cours élémentaire de paléontologie et de géologie stratigraphiques: Paris, V. Masson, 3 v.

Osborn, H. F., 1908, New fossil mammals from the Fayûm Oligocene, Egypt: American Museum of Natural History Bulletin, v. 24, article 16, p. 265-272.

Owen, D. D., 1852, Report of a geological survey of Wisconsin, Iowa, and Minnesota, and incidentally of a portion of Nebraska Territory made under instructions from the United States Treasury Department: Philadelphia, 638 p., 15 pls.

Owen, Richard, 1862, Report of a geological reconnaissance of Indiana made during the years 1859 and 1860 under the direction of the late David Dale Owen, M.D.: Indianapolis, 368 p.

Parks, J. M., 1951, Corals from the Brazer Formation (Mississippian) of northern Utah: Journal of Paleontology, v. 25, no. 2, p. 171-186, pls. 29-33, 3 figs.

Phillips, John, 1836, Illustrations of the geology of Yorkshire; or, A description of the strata and organic remains accompanied by a geological map, sections, and diagrams, and figures of the fossils. Pt. 2, The mountain limestone district: London, J. Murray, $253 \mathrm{p}$.

Price, P. H., 1929, Pocahontas County: West Virginia Geological Survey, County Reports, 531 p., 71 pls., 21 figs., 2 maps.

Pyzh'anov, I. V., 1964, Novy rod chetyrekhluchevykh korallov iz srednekamennougol'nykh otlozheniy Darvaza [New genus of tetracorals from Middle Carboniferous beds of Darvaz]: Tadzhik SSR, Upravlenie Geologii i Okhrany Nedr, Trudy, Paleontologiya i Stratigrafiya, no. 1, p. 169-174.

Reuss, A. E., 1854, Beiträge zur Charakteristik der Kreideschichten in den Ostalpen, besonders im Gosauthale und am Wolfgangsee: Kaiserliche Akademie der Wissenschaften, MathematischNaturwissenschaftliche Klasse, Denkshrift, v. 7, 156 p., 31 pls.

Richardson, G. B., 1941, Geology and mineral resources of the Randolph quadrangle, Utah-Wyoming: U.S. Geological Survey Bulletin 923,55 p., 8 pls., 2 figs.

Roemer, Ferdinand, 1883, Lethaea geognostica. Theil 1. [Lethaea Palaeozoica]: Stuttgart, E. Schweizerbart, v. 1, pt. 2, p. 113-544.

Rominger, C. L., 1876, Paleontology-Fossil corals: Michigan, Geological Survey, v. 3, pt. 2, 161 p.

Ross, J. P., and Ross, C. A., 1963, Late Paleozoic rugose corals, Glass Mountains, Texas: Journal of Paleontology, v. 37, no. 2, p. 409-420, pls. 48-50, 2 figs.

Rukhin, L. B., 1938, Nizhnepaleozoyskie korally i stromatoporoidei verkhney chasti basseina r. Kolymy![Lower Paleozoic corals and stromatoporoids of the upper part of the Kolyma river basin]: Moscow, Gostrest Dal'stroy, Materialy po Kolymsko-Indigirskogo Kraya, Ser. 2, Geologii i Geomorfologii, no. 10, 119 p., 28 pls. (English summary.)

Sando, W. J., 1963, New species of colonial rugose corals from the Mississippian of northern Arizona: Journal of Paleontology, v. 37, no. 5 , p. 1074-1079, 1 fig., pls. $145,146$.

1969, Corals, Chap. 6 of McKee, E. D., and Gutschick, R. C., History of the Redwall Limestone of northern Arizona: Geological Society of America Memoir 114, p. 257-344, pls. 29-40, figs. 52-75.

1975, Coelenterata of the Amsden Formation (Mississippian and Pennsylvanian) of Wyoming: U.S. Geological Survey Professional Paper $848-\mathrm{C}, 31$ p., 10 pls., 6 figs.

1976 , Revision of the Carboniferous genus Aulina Smith (Coelenterata, Anthozoa): U.S. Geological Survey Journal of Research, v. 4, no. 4, p. 421-435, 6 figs.

Sando, W. J., Bamber, E. W., and Armstrong, A. K., 1975, Endemism and similarity indices; clues to the zoogeography of North
American Mississippian corals: Geology, v. 3, no. 11, p. 661-664, 8 figs.

1977, The zoogeography of North American Mississippian corals, in Second International Symposium on Corals and Fossil Coral Reefs, Paris, 1975: [France], Bureau de Recherches Géologiques et Minières Mémoire 89, p. 175-184, 9 figs.

Sando, W. J., Dutro, J. T., Jr., and Gere, W. C., 1959, Brazer dolomite (Mississippian), Randolph quadrangle, northeast Utah: American Association of Petroleum Geologists Bulletin, v. 43, no. 12, p. 2741-2769, 5 figs.

Sando, W. J., Mamet, B. L., and Dutro, J. T., Jr., 1969, Carboniferous megafaunal and microfaunal zonation in the northern Cordillera of the United States: U.S. Geological Survey Professional Paper 613-E, 29 p., 7 figs.

Sanford, W. G., 1939, A review of the families of tetracorals: American Journal of Science, v. 237, no. 5, p. 295-323; no. 6, p. 401-423, 16 figs.

Schmidt, H., 1929, Tierische Leitfossilien des Karbon, in Gurich, G., Leitfossilien: Berlin, v. 6, 107 p., 23 pls.

Shimer, H. W., 1926, Upper Paleozoic faunas of the Lake Minnewanka section, near Banff, Alberta: Canada Geological Survey Bulletin 42 , p. 1-84, pls. $1-8$, fig. 1 .

Smith, Stanley, 1916, The genus Lonsdaleia and Dibunophyllum rugosum (McCoy): Geological Society of London Quarterly Journal, no. 282 , v. 71 , pt. 2 , p. 218-272.

Smith, Stanley, and Yü, C. C., 1943, A revision of the coral genus Aulina Smith and descriptions of new species from Britain and China: Geological Society of London Quarterly Journal, no. $393-394$, v. 99 , pts. $1-2$, p. 37-61.

Solov'eva, V. V., 1963, O mikrostruckture skeletnykh elementov nekotorykh Srednekamennougol'nykh rugoz podmoskov'ya [Microstructure of skeletal elements in certain Middle Carboniferous Rugosa from the Moscow area]: Paleontologicheskiy Zhurnal, 1963, no. 3, p. 113-116, 6 figs.

Soshkina, E. D., Dobrolyubova, T. A., and Kabakovich, N. V., 1962, Podklass Tetracoralla [Subclass Tetracoralla], in Orlov, Yu. A., ed., Osnovy paleontologii [Fundamentals of paleontology]: Akademiya Nauk SSSR, Ministerstvo Geologii i Okhrany Nedr SSSR, Ministerstvo Vysshego Obrazovaniya SSSR, v. 2, p. 286-356, 23 pls., 108 figs. (English translation published by Israel Program for Scientific Translations, 1971.)

Soshkina, E. D., Dobrolyubova, T. A., and Porfir'ev, G., 1941, Permskie Rugosa Evropeyskoy chasti SSSR [Permian Rugosa of the European part of the USSR], in Likharev, B. K., ed., Paleontologiya SSSR [Paleontology of the USSR], v. 5, pt. 3, no. 1: Akademiya Nauk SSSR, Paleontologicheskiy Institut, 304 p., 63 pls., 44 figs. (English summary.)

Stensaas, L. J., and Langenheim, R. L., Jr., 1960, Rugose corals from the Lower Mississippian Joana limestone of Nevada: Journal of Paleontology, v. 34, no. 1, p. 179-188, 10 figs.

Stuckenberg, A. A., 1888, Korally i mshanki verkhnego yarusa srednerusskogo Kamennougol'nogo izvestnyaka [Corals and Bryozoa from the upper part of the Middlerussian Carboniferous Limestone]: Russia Geologicheskiy Komitet Trudy, v. 5 (1888-1890), no. 4, 54 p., 4 pls. (German summary.)

-1895 , Korally i mshanki Kamennougol'nykh otlozheniy Urala i Timana [Corals and Bryozoa from the Carboniferous deposits of the Urals and Timan]: Russia Geologicheskiy Komitet Trudy,.v. 10 (1890-1895), no. 3, 244 p., 24 pls.

Sutherland, P. K., 1958, Carboniferous stratigraphy and rugose coral faunas of northeastern British Columbia: Canada Geological Survey Memoir 295, $177 \mathrm{p}$.

1977, Analysis of the Middle Carboniferous rugose coral genus Petalaxis and its stratigraphic significance, in Second International Symposium on Corals and Fossil Coral Reefs, Paris, 1975: 
[France] Bureau de Recherches Géologiques et Minières Mémoire 89, p. $185-189,1 \mathrm{pl}$.

Tolmachev, I. P., 1924-1931, Nizhnekamennougol'naya fauna Kuznetskogo uglenosnogo basseina [Lower Carboniferous fauna of the Kuznetsk coal basin]: Russia, Geologicheskiy Komitet, Materialy po obschchei i prikladnoy geologii, no. 25,2 v.: pt. 1, p. 1-320, 12 pls., 10 figs. (1924); pt. 2, p. 321-663, 11 pls., 1 fig. (1931).

1933, New names for two genera of Carboniferous corals: Geological Magazine, v. 70, no. 6, p. 287.

Trautschold, H. A. von, 1879, Die Kalkbrüche von Mjatschkowa, eine Monographie des oberen Bergkalks. Schluss: Société Impériale des Naturalistes de Moscou, Nouveaux Mémoires, v. 14, p. 101-180, pls. 12-18. (Last of 3 pts. Pts. 1 (1874) and 2 (1876) pub. in v. 13.)

Ulrich, E. O., 1905, Geology and general relations, in Ulich, E. O., and Smith, W. S. T., The lead, zinc, and fluorspar deposits of western Kentucky: U.S. Geological Survey Professional Paper 36, pt. 1, p. $7-105$, pls. $1-7$.

Vasilyuk, N. P., 1960, Nizhnekammenougl'nye korally Donetskogo basseina [Lower Carboniferous corals of the Donets basin]: Akademiya Nauk Ukrainskoy SSR, Institut Geogichnykh Nauk Trudy, Seriya Stratigrafii i Paleontologii, No. 13, 178 p., 42 pls. 1964, Korally zon $\mathrm{C}_{1}{ }^{\mathrm{v}} \mathrm{g}-\mathrm{C}_{1}{ }^{\mathrm{n}} \mathrm{a}$ of the Donets basin, in Aizenverg, D. E., ed., Materialy $k$ faune verkhnego paleozoya Donbassa [Contributions to the upper Paleozoic fauna of the Donbass]: Akademiya Nauk Ukrainskoy SSR, Institut Geologichnykh Nauk Trudy, Seriya Stratigraffi i Paleontologii, No. 48, p. 60-103, pls. 1-8. (In Ukrainian.)

Vaughan, Arthur, 1905, The palaeontological sequence in the Carboniferous Limestone of the Bristol area: Geological Society of London Quarterly Journal, v. 61, p. 181-305.

1906, The Carboniferous Limestone Series (Avonian) of the Avon Gorge: Bristol Naturalists' Society Proceedings, ser. 4, v. 1, pt. 2, p. $74-168$, pls. 1-16.

Wang, H. C., 1950, A revision of the Zoantharia Rugosa in the light of their minute skeletal structures: Royal Society of London Philosophical Transactions, Ser. B, Biological Science, no. 611, v. 234, p. 175-246, pls. 4-8, figs. 76-79.

Warren, P. S., 1927, Banff area, Alberta: Canada Geological Survey Memoir 153, 94 p., 3 pls., 1 fig.

Weller, J. M., 1931, Mississippian fauna: Kentucky Geological Survey Ser. 6, v. 36, p. 249-290, 12 pls., 1 fig.

Weller, J. M., Grogan, R. M., and Tippie, F. E., 1952, Geology of the fluorspar deposits of Illinois: Illinois State Geological Survey Bulletin 76, $147 \mathrm{p}$.

Weller, Stuart, 1898, A bibliographic index of North American Carboniferous invertebrates: U.S. Geological Survey Bulletin 153, 653 p.

Weller, Stuart, with collaboration of Butts, Charles, Currier, L. W., and Salisbury, R. D., 1920, The geology of Hardin County: Illinois State Geological Survey Bulletin 41, 416 p., 11 pls., 30 figs.

Weller, Stuart, and St. Clair, Stuart, 1928, Geology of Ste. Genevieve County, Missouri: Missouri Bureau of Geology and Mines, 2 d ser., v. 22, 352 p., 5 figs., 25 pls., 2 maps.

White, C. A., 1880a, Contributions to invertebrate paleontology no. 8: Fossils from the Carboniferous rocks of the Interior States: U.S. Geological and Geographical Survey of the Territories (Hayden), Annual Report 12, pt. 1 (1883, advance printing 1880), p. 155-171, pls. $39-42$.

$-1880 \mathrm{~b}$, Fossils of the Indiana rocks: Indiana Department of Statistics and Geology, Annual Report 2, p. 471-522.
1882, Fossils of the Indiana rocks, no. 2: Indiana Department of Geology and Natural History, Annual Report 11, p. 347-401.

Wilmarth, M. G., 1938, Lexicon of geologic names of the United States (including Alaska): U.S. Geological Survey Bulletin 896, 2v. 2,396 p.

Wilson, E. C., and Langenheim, R. L., Jr., 1962, Rugose and tabulate corals from Permian rocks in the Ely quadrangle, White Pine County, Nevada: Journal of Palentology, v. 36, no. 3, p. 495-520, pls. 86-89, 4 figs.

Wilson, M. E., 1922, The occurrence of oil and gas in Missouri: Missouri Bureau of Geology and Mines, 2d ser., v. 16, 284 p., 11 pls.

Wu, W. S., 1964, [Lower Carboniferous corals in central Hunan]: Academia Sinica, Institute of Geology and Palaeontology, Memoir 3, p. 1-100, pls. 1-16 (In Chinese, English summary.)

Wu, W. S., and Zhao, J. M., 1974, [Carboniferous corals] in [Handbook of the stratigraphy and paleontology of southwest China]: Nanking Institute of Geology and Paleontology, Academia Sinica, p. 265-273. (In Chinese.)

Yabe, Hisakatsu, and Hayasaka, Ichirô, 1915, Palaeozoic corals from Japan, Korea, and China: Geological Society of Tokyo Journal, v. 22, p. 55-70, 79-92, 93-109, 127-142.

1920, Paleontology of southern China: Tokyo, Tokyo Geographical Society, 221 p., 27 pls. (in portfolio).

Yamagiwa, Nobuo, 1961, The Permo-Carboniferous corals from the Atetsu Plateau and the coral faunas of the same age in southwest Japan: Osaka University, Liberal Arts and Education Memoir, Ser. B, Natural Science, no. 10, p. 77-114, 8 pls., 2 figs.

Yanishevskiy, M. E., 1900, Fauna Kamennougol'nogo izvestnyaka vystupayushchego po $r$. Shartymke na vostochnom sklon Urala [Fauna of the Carboniferous Limestone along the Sartymka River on the west slope of the Urals]: Kazan Universitet, Obshchestvo Estestvoispytatelei Trudy, v. 34, no. 5, p. 1-379, 7 pls. (German summary.)

Yoh, S. S., 1961, On some new tetracorals from the Carboniferous of China: Acta Palaeontologica Sinica, v. 9, no. 1, p. 1-17, pls. 1-3. (In Chinese, English summary.)

Yoh, S. S., and Huang, T. K., 1932, The coral fauna of the Chihsia Limestone of the lower Yangtse Valley: Palaeontologia Sinica, ser. B., v. 8, pt. 1, p. 1-72, pls. 1-10.

Yokoyama, Tsuruo, 1957, Notes on some Carboniferous corals from Taishaku district, Hiroshima prefecture, Japan: Hiroshima University, Journal of Science, Ser. C (Geology), v. 2, no. 1, p. 73-82, pls. 10-12, 2 figs.

Yü, C. C., 1933, Lower Carboniferous corals of China: Palaeontologia Sinica, Ser. B, v. 12, fasc. 3, 211 p., 24 pls. [1934]

1962, [Revision of some Permo-Carboniferous rugose corals]: [Changchun Geological Academy 10th Anniversary Science Papers], p. 1-11. (In Chinese.)

Yü, C. C., Lin, I. D., and Fan, Y. N., 1962, [The rugose corals of the Permo-Carboniferous Periods in Sinkiang and Chinghai (Tsinghai) Provinces]: [Changchun Geological Academy, 10th Anniversary Science Paper], p. 13-35, pls. 1-4 (In Chinese.)

Yü, C. M., Wu, W. S., Chao, C. M., and Chang, C. C., 1963, [Fossil corals of China]: Peking, 390 p., 98 pls. (In Chinese.)

Zhizhina, M. S., 1956, Semeystvo Lithostrotionidae Grabau, in Kiparisova, L. D., Markovskiy, B. P., and Radchenko, G. P., eds., Materialy po paleontologii; novye semeistva i rody [Contributions to paleontology; new families and genera]: Vsesoyuznyy NauchnoIssledovatel'skiy Geologicheskiy Institut (VSEGEI), Materialy po paleontologii, novaya seriya, no. 12 , p. 39-41, pl. 9. 



\section{INDEX}

\section{[Italic page numbers indicate major references]}

Abstract

Acknowledgements

Acrocyathidae

Acrocyathus

cystosus

floriformis $10,11,16$

hemisphaericus $3,5,18,19,41 ; \mathrm{pl} .12,13,14$ girtyi

grechoyka

$3,5,16,21 ; \mathrm{pl} .17$

houjuling

$5,21,28$

lissitzini

16,22

pennsylvanicus

pilatus

proliferus

$3,5,16,19,21 ;$ pl. 17

rotai $5,16,21$

shimeri

$8,16,22,23$

utkae

$5,16,22$

zhizhinae

$5,15,21$

spp

$5,16,29$

spp

5,17

Additional taxa

Actinocyathus

$-\quad 25$

(Atinocyathus), Lonsdaleia

berthiaumi, Lonsdaleia

$6,18,37$

peratrovichensis, Lonsdaleia _____________ 6, 8, 37

stelcki, Lonsdaleia

8,37

Alabama

Alapah Limestone

Alaska

allisonae, Petalaxis

altaicum, Lithostrotion

Stelechophyllum venukoffi

americana, Lithostrotionella

pl. $3,4,5,6$

americanum, Lithostrotion [Lithostrotionella] _-.-- 17, 18 ascendens, Stelechophyllum

Stelechophyllum ascendens

simplex

Stylophyllum -

Thysanophyllum ascendens --_-_-_-_-_-_ $\quad 89$

simplex

ascendens, Stelechophyllum Thysanophyllum _-_-_-_-_-_-_-_-_-_ $\quad s 9$

simplex, Stelechophyllum _._-_._- 5, 10, 39

Thysanophyllum

Aspen Range Formation

Astraea -

mamillaris

astraeiforme, Thysanophyllum _-_-_-_-_-_-_--- 6, 37

astraeiformis, Lithostrotionella

Lithostrotionella (Thysanophyllum) _______

Aulina tubifera -_._-_._-_-_-_-_-_-_-_---- 15

Aulostylus

tubiferus

eotubiferus

tubiferus ----------------_------- $3,5,7,15$

$5,7,15$
$--5,15$

awenggouensis, Lithostrotionella

Axinura canadensis

B

baijinensis, Lithostrotionella

Page
bailliei, Lithostrotionella
Petalaxis
basaltiforme, Lithostrotion

California

canadense, Lithostrotion _-_ 17, 20

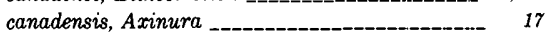

canadensis, Lithostrotion

cantabrica, Lithostrotionella (Hillia) _-_____-_._ $\quad 31$

cantabricus, Petalaxis

Carcinophyllum

8
$--17,19$

Castelnaui, Lithostrotion

Lithostrotionella $3 ; \mathrm{pl}$. 7, 8, 9, 10,14

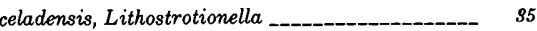

Petalaxis _._. $5,25,35$

changshunensis, Lithostrotionella _-_-___-_.-. $\quad 39$

Cherokee Shale _-_-_-_-_-_-_-_-_-_-_-1, 40

circinatum, Stelechophyllum _-_-_-_-_ $5,10,12$

circinatus, Lithostrotion (Lithostrotionella.) --_-_- 12

Lithostrotionella

Classification

Clisiophyllum

Columnariina

Confertus, Petalaxis $5,25,99$

confluens, Lithostrotionella _-__-___-_-_ 12

crassus, Lithostrotionella $\quad 40$

crenulare, Cyathophyllum _-_-_-_-_-_-_- $\quad 37$

Cyathophyllum crenulare

Cystolonsdaleia _..._-__-_____-_-_ 1, 4, 6, 24, 35

portlocki 22

densiconus, Lonsdaleia portlocki

dilatata, Kleopatrina

Kleopatrina (Kleopatrina)

Lithostrotion [Lithostrotionella]

Diphyphyllum

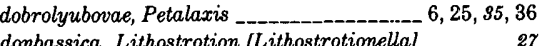
Lithostrotionella donbassicus, Petalaxis _-_-_-_-_-_ $5,25,27,29$ donetsensis, Petalaxis _-_-_-_-_-_-_-_-_-_-_ 25, 36 duplicata, Lonsdaleia _-_-_-__-___-_-_-_-_ $\quad 37$ duplicatus, Erismatolithus Madreporites .-_-_-- $s 7$

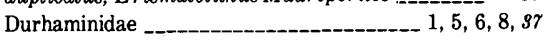
Durhamina

dushanensis, Lithostrotionella
Page

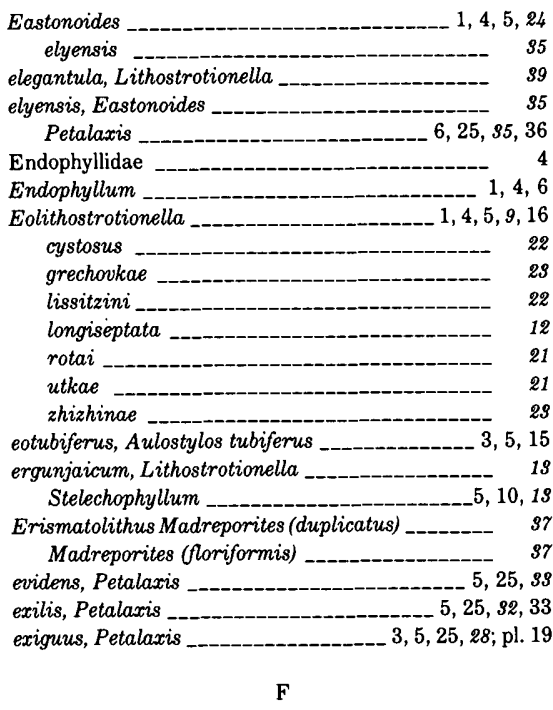

Faberophyllum 40

flexuosa, Lithostrotionella flexuosum, Lithostrotion

Lithostrotion [Lithostrotionella] _-_- $2 \gamma$

flexuosus, Petalaxis _-_-_-_-_-_-_ 5, 25, 27, 29, 30, 32, 34 floriformius, Acrocyathus _._____ 5, 16, 17, 19, 20, 21 Acrocyathus floriformis _._ 3, 5, 7, 16, 17, 41; pl. 5,6 $7,8,9,10,11,16$

Lithostrotionella $3,1317,18,20$

Lonsdaleia

floriformis, Acrocyathus _.___ 3, 5, 7, 16, 17, 41; pl. 5 , $6,7,8,9,10,11,16$

hemisphaericus, Acrocyathus _- 3, 5, 18, 19, 41; pl. 12

13,14

(floriformis), Erismatolithus Madreporites __-_-_ $\quad 37$

fomichevi, Petalaxis

"Formenreihe" method

fomichevi, Petalaxis

25

Ptolemaia
fugimotoi, Lithostrotionella

G

girtyi, Acrocyathus $-3,5,16,21 ; \mathrm{pl} .17$ Lithostrotion [Lithostrotionella] _-_-_-__-_ 28 Lithostrotionella grande, Lithostrotion _-__________-_ 11

Stelechophyllum _-______._._._. 5, 10,11 grandis, Petalaxis _-_-_-_-_-_-_-_-_-_-_-_ 38

grechovkae, Acrocyathus _- $5,21,2 s$

Eolithostrotionella -_-_-_ 23

Greenbrier Limestone -..--.

Hillsdale Member - 3

Granitville, Utah $5,25,30$

hemisphaerica, Lithostrotionella _- 3, 12, 15, 18, 19; pl. 2, $4,10,11$ 


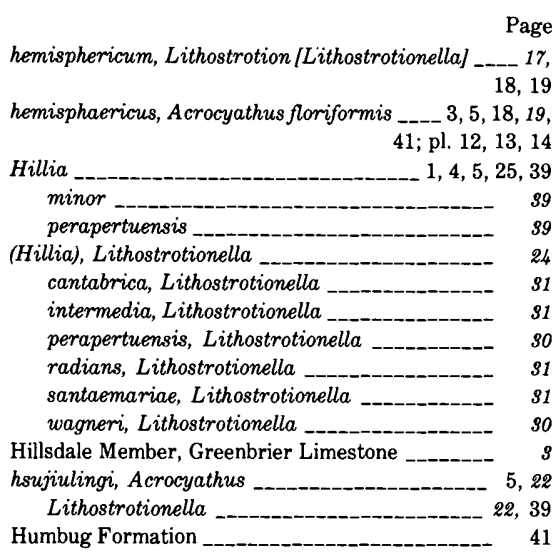

\section{I}

Idaho

3,40

Illinois

$3,20,40$

immanis, Petalaxis -..- $5,25,29$

inconfertus, Petalaxis - 38

indigae, Petalaxis

intermedia, Lithostrotionella (Hillia) _- 31

intermedius, Petalaxis _-_. 25,81

Introduction

ivanovi, Lithostrotionella

Lonsdaleia

Petalaxis

$6,25,36$

$\mathrm{J}$

jasperensis, Lithostrotion [Lithostrotionella] _.._- $\quad 12$

Lithostrotionella jiaruoensis, Lithostrotionella

\section{K}

kennedyi, Petalaxis

39

Kentucky

Kleopatrina

dilatata
uralica

wahooensis

(Kleopatrina)

dilatata

ftatateeta

uralica

wahooensis

(Porfierevella)

(Kleopatrina), Kleopatrina

dilatata, Kleopatrina

ftatateeta, Kleopatrina

uralica, Kleopatrina

wahooensis, Kleopatrina _-_-_-_-_-_-_-_-- 38

korkhovae, Petalaxis

kwechouensis, Lithostrotionella _-_-_-_-_-_ 38,39

magna, Lithostrotionella _-_-_-_-_-_-_ $\quad 39$

Kuechow Province, China

kunthi, Petalaxis

Kuznetsk Basin

L

lisitschanskensis, Petalaxis $5,25,32$ Petalaxis vesiculosa

lissitzini, Acrocyathus

$-32$

Eolithostrotionella

Lithostrotion

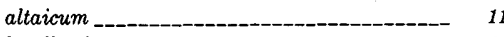

banffensis --_-_-_-_-_-_-_-_-_-_--- 19

basaltiforme _- 17

canadense _-_-_-_-_-_- 17,20

canadensis --_-_-_-_-_-_-_-_-_-_-_-_ 17,19

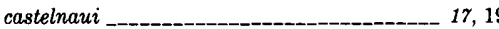

flexuosum

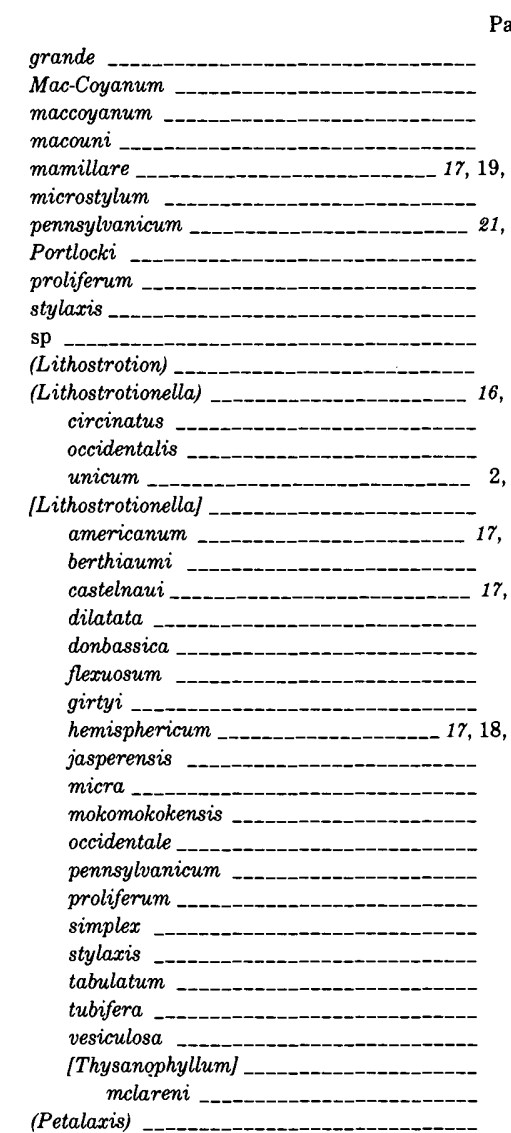

(Lithostrotion), Lithostrotion

Lithostrotionella _._-_._- 1, 2, 4, 5, 8, 9, 15, 16, 22, 2s, 39 americana astraeiformis

awenggouensis

baijinensis

bailliei

banffense

banffensis

birdi

brokawi

castelnaui

celadensis --

changshuensis

circinatus

confluens

crassus

donbassica

dushanensis

elegantula

ergunjaicum

flexuosa

floriformis

fugimoto

girtyi--

hsujiulingi

ivanovi

jasperensis

jiaruoensis

kitakamiensis

age

34
34

15

22

34

magna $\quad 39$

lochmanae -

maccoyana _-_-_-_ $30,34,39$

major -.-_ 29

macouni

mclareni

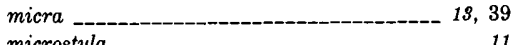

microstylum _-_-_-_-_-_ 12 mohikana Page

monocyclica

mui

multiradiata _-_-_-_-_-_-_-_-_-_-_.. 3, 12; pl. 1

multivesiculata _-_-_-_-_-_-_-_-_ 39

niakensis _._- 14

orboensis -_-_-_-_-_-_- 31,39

regularis _-_-____-_-_-_-_ 39

pennsylvanica _______________ 23, 40

pennsylvanicum -_-_-_-_-_-_-_-_-_-_----- 21

peratrovichensis --_-_-_-_-_-- 37

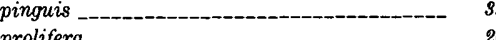

prolifera

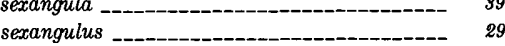

shimeri

simplex _-_-_-_-_-_-_-_-_-_-_-_-_ 3, 26; pl. 18

spiniformis _ 56,39

stylaxis uralica

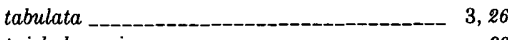

taishakuensis _-_-_-_-_-_-_-_-_-_-_---- 29

tingi

tschucotica

tubifera -

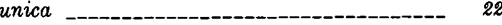

unicum - 2,22

uralica -_-_-_-_-_-_-_-_-_-_-_-_-_-_-_ 38

vesicularis _-_-_-_- 3,13

vesiculosa

vesiculosa - -

wahooensis _-_-_-_- 38

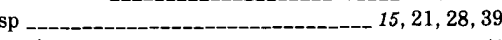

sp. A - -

sp. B _-_-_-_-_-_-_-_-_-_-_-_-_-_ 14

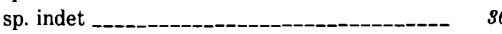

sp. undet -

Hillia)

cantabrica

31

radians -

santaemariae -----_-_------------ $\quad 31$

wagneri _-______-_-_-_-_-_-_-_ 30

(Thysanophyllum) astraeiformis _-_-_-_--- $\quad 87$

[Lithostrotionella], Lithostrotion -_-_-_-_-_-- 9

americum, Lithostrotion _-_-_-_-_-_-_--- 17, 18

berthiaumi, Lithostrotion _-_-_-_-_-_-_-_-_-- 37

castelnaui, Lithostrotion _-_ 17,

dilatata, Lithostrotion _-_-_-_-_-_-_-_ $\quad 38$

donbassica, Lithostrotion --_---------- $\quad 27$

flexuosum, Lithostrotion ----------------

girtyi, Lithostrotion

hemisphericum, Lithostrotion
jasperensis, Lithostrotion

micra, Lithostrotion

mokomokensis, Lithostrotion ------_-------- 28

occidentale, Lithostrotion _-_-_-_-_-_-_-_-_-- 32

pennsylvanicum, Lithostrotion -.--_-_-_--- 21

proliferum, Lithostrotion -_-_-_-_-_-_-_ 20

simplex, Lithostrotion --_-_-_------------ 26

stylaxis, Lithostrotion --_-_-_---_-_----- 34

tabulatum, Lithostrotion -_-_-_-_-_-_ 26

tubifera, Lithostrotion -

vesiculosa, Lithostrotion

[Thysanophyllum], Lithostrotion _-_-_-_-_-_-- 9

mclareni, Lithostrotion --_--_-_-_--- 14

(Lithostrotionella), Lithostrotion -_-_-_-_-_-_ 16, 23

circinatus, Lithostrotion _._-_-_-_-_-_ 12

occidentalis, Lithostrotion ---------------- 32

unicum, Lithostrotion _-__-__-__-___-_-_, 2, 22

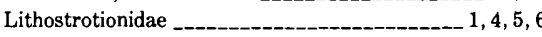

Little Flat Formation _-_._-_-_.-_ 3, 13, 21, 26, 41

Locality data, USNM specimens not Hayasaka. types _-_-_- 41

lochmanae, Lithostrotionella _-_-_-_-_- 19 Stelechophyllum Lodgepole Limestone -_-

longiseptata, Eolithostrotionella 
Page Stelechophyllum $1,2,4,5,6,8,16,20,24,37$ duplicata floriformis _-_-_-_-_-_-_-_-_-_-_-_-_-_ 37 ivanovi _-___-_ 25, 35, 36 pennsylvanica portlocki _-_-_- 25,35 densiconus _-_._-_-_-_-_-_-_-_-_-_-_-_ 36

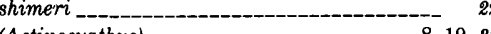

(Actinocyathus) berthiaumi _-_-_-_-_-_-__-_ $18, s 7$; pl. 20 peratrovichensis _..._._._._._-_._._-_ 6, 8,37 stelcki 8,37

(Lonsdaleia) 37

(Lonsdaleia), Lonsdaleia

Lonsdaleiidae

Lonsdalia.

longiseptata

lutugini, Cystolonsdaleia

\section{M}

maccoyana, Lithostrotionella

Petaluxis

major, Lithostrotionella

multiseptata, Petalaxis

orlowkensis, Petalaxis $\quad 36$

Mac-Coyanum, Lithostrotion -.-_-_-_-_ $\quad 34$

maccoyanum, Lithostrotion -.-_-_-_-_--_--_- 34

maccoyanus, Petalaxis _-- 2, 5, 7, 24, 25, 27, 30, 34, 35, 36

macouni, Lithostrotion

Lithostrotionella _-_- 15

Stelechophyllum _-_._-_-_-_-_-_-_ 10, 15

Madison Limestone ----_-_-_-_-_-_-_------ 3

Madreporites (duplicatus), Erismatolithus _ $\quad 37$ (floriformis), Erismatolithus _-_---_-_-_ $\quad 37$ magna, Lithostrotionella kuechouensis _-_-_----- $\quad 39$

major, Lithostrotionella maccoyana _-_-_-_-_

Petalaxis $5,25,29$

mamillare, Lithostrotion

mamillaris,

McCloud Limestone

mccoyana, Petalaxis _.___ 29, 34

belinskiensis, Petalaxis _ 29

mccoyanus, Petalaxis

mclareni, Lithostrotion [Lithostrotionella] [Thysanophyllum]

Lithostrotionella

Stelechophyllum

M'coyana, Petalaxis

Stylaxis

--- 24,3

Stylophyllum

Meridian Range, Mont _- 3

micra, Lithostrotion [Lithostrotionella] ---_--- 13

Lithostrotionella _________________ 18, 19

microstyla, Lithostrotionella _-___ 11

microstylum, Lithostrotion

Lithostrotionella

Stelechophyllum $\quad 3,5,10,11 ; \mathrm{pl}, 1,2$

micrum, Stelechophyllum -_-_-____-_ 5, 10, 19

minor, Hillia

mirus, Petalaxis _-_- $5,25,39$

Mission Canyon Limestone ------------------ 3

Missouri --_-_-_--_-_- 3,40

mohikana, Lithostrotionella _._-__-_-_-_-_- 34

Petalaxis -_-__-_- 34

mohikanus, Petalaxis _._- 5, 25, 34 mokomokensis, Lithostrotion /Lithostrotionella] _-- 28

Petalaxis

monocyclica, Lithostrotionella _-_-_-_-_-_-_-_ 28

monocyclicus, Petalaxis _-_-_-_-_-_-_ 25,28

Moscow Basin

mui, Lithostrotionella

multiradiata, Lithostrotionella

multiseptata, Petalaxis maccoyana

multivesiculata, Lithostrotionella _-_-_-_----- $\quad 39$

N

Namurian
Nematophyllum

Page

Newman Limestone

24

niakense, Stelechophyllum

naikensis, Lithostrotionella

Stelechophyllum

O

occidentale, Lithostrotion [Lithostrotionella] _-_--_ $\quad 32$ accidentalis, Lithostrotion (Lithostrotionella)

Petalaxis _-___-_________-_ 25, 32; pl. 20

orboensis, Lithostrotionella _-_-_ 31,39

Petalaxis _-__-_-_-_-_-_-_-_-_-_-_ 5, 25, 31

regularis, Lithostrotionella _._._._.___._ $\quad 39$

orientale, Thysanophyllum _-_-_-_-_-_-_-_-_ 37

orlovkensis, Petalaxis maccoyana

\section{$\mathrm{P}$}

pecki, Petalaxis pennsylvanica, Lithostrotionella__-_- 31,39

Lonsdaleia

pennsylvanicum, Lithostrotion

Lithostrotion [Lithostrotionella] _....._-_._- 21

Lithostrotionella

pennsylvanicus, Acrocyathus _-_-_-_-_ 5, 8, 16, 21

perapertuensis, Hillia $\quad 39$

Lithostrotionella (Hillia) _-_-_-__-__-_-_-_ $\quad 30$

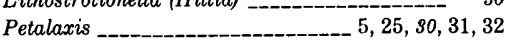

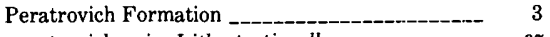

peratrovichensis, Lithostrotionella _-__-_-_ $\quad 37$

Lonsdaleia (Actinothyathus)

persubtilis, Petalaxis _-_-_-_-_-_-_-_-_ $5,25, s 8$

Petalaxidae

$1,4,5,29$

Petalaxis $1,2,4,5,6,7,9,16,22,23,24,26,27,28$, $29,30,31,32,33,39$

allisonae
bailliei bailliei__ $5,25,27$

besti _-_ $\quad 39$

brokawi _-_ $5,25,28$

cantabricus _-_-_- $5,25,31$

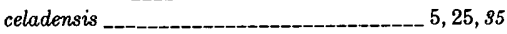

confertus $5,25,33$

dobrolyubovae $6,25,35,36$

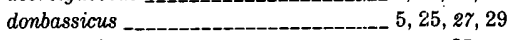

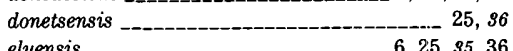

elyensis _-_-___-_-__-_-_ $6,25,35,36$

evidens _-_-_-_-_
exiguus _-_-_-_-_ $3,25,33$

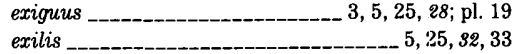

flexuosus _-_________ 5, 25, 27, 29, 30, 32, 34

fomichevi 5,30

fomichevi

grandis

grootae _-_-_-_-_ 5, 25, 30

immanis _-__

inconfertus

indigae -

intermedius -

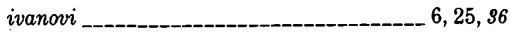

kennedyi

korkhovae $5,25,39$

kunthi

lisitschanskensis _._______________ 5, 25, 32

maccoyana _-__-_ 30,34 multiseptata orlovkensis _-_-_-_-_-_- 36 maccoyanus _-_-_-_ 2, 5, 7, 24, 25, 27, 30, 34, 35, 36 major mecoyana belinskiensis - 29 mccoyanus _- 30

M'coyana _-_-_-_-_-_-_-_-_-_-_-_-_-_ 24, 94

mirus _-____ $5,25,39$

mohikana

mohikanus _-_- $5,25,34$

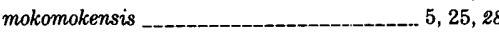

monocyclicus _._._._._._._._._._._._. 5,28

occidentalis _-_-_-_-_-_-_ $5,25,32 ; \mathrm{pl} .20$
Page

orboensis $5,25,31$ peck perapertuensis _-_-___-__-_-_-_._-_ $5,30,31,32$ persubtilis _-_-_____-_-_-_-_-_-_-_-_-_-_ $5,25,39$ portlocki _-_-_-_-_-_-_-_-_-_-_-_ 2,35

radians $5,25,31$

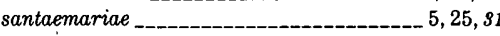
sexangulus _-__-__-_-_ $5,25,29$ sibiricus

simplex $3,5,25,26$; pl. 18

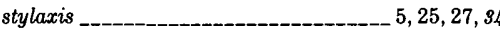
sutherlandi

tabulatus _-_-_____-_ 3, 5, 25, 26, 27; pl. 19

taishakuensis $\quad 5,25,29$

timanicus _-________- 36,38

tschucoticus _-_- 25,27

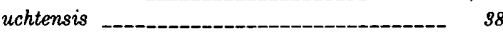

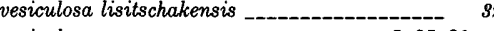

vesiculosus

wagneri

$5,25,30,31,32$

wyomingensis _-_-_-_-_-_-_-_ 3, 25, 26, 27; pl. 18

spp

spp. indet

Phylogeny

pilatus, Acrocyathus $3,5,16,19,21 ; \mathrm{pl} .17$

pinguis, Lithostrotionella

Porcupine-Arctic section 3

(Porfierevella), Kleopatrina --_-_-_-_-_-_-_ 38

portlocki, Cystolonsdaleia _-_-_-_-_-_-_-_-_ $\quad 35$

Lonsdaleia _-_-_-_-_-_-_-_-_-_-_-_-_-_-_ 25, 35

Petalaxis _-_ 2,35

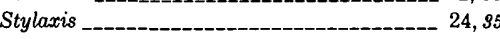

densicionus, Lonsdaleia

Portlocki, Lithostrotion

prolifera, Lithostrotionella

proliferum, Lithostrotion

Lithostrotion [Lithostrotionella] --_-_-16, 20

Protolonsdaleia

Protolonsdalia

Pseudodorlodotia

Ptolemaia

ftatateeta

$\mathrm{R}$

radians, Lithostrotionella (Hillia)

Petalaxis

References cited

Register of USGS localities, Hayasaka (1936)

Lithostrotionella type specimens _._._. 40

regularis, Lithostrotionella orboensis $\quad 39$

rotai, Acrocyathus _-_-_-_-_-_-_-_-_-_-_-_-_ 5, 16, 21

Eolithostrotionella -

Rugosa

$1,5,6$

\section{$\mathrm{S}$}

St. Louis Limestone

$3,20,40$

santaemariae, Lithostrotionella (Hillia) _._._._-_ $\quad 31$

Petalaxis
Pithostrotionella (Hillia)

Sciophyllum

14,33

sexangula, Lithostrotionella

sexanguls, Lithostrotionella

Petalaxis

$\quad 39$

shimeri, Acrocyathus _-_-_-_-_-_-_-_ 5, 8, 16, 22, 23

Lithostrotionella _._............_-__-__-_-_ 2s, 40

Lonsdaleia

sibiricus, Petalaxis

$\begin{array}{lr}\text { Lithostrotionella } & 26 \\ & \end{array}$

Petalaxis _-_________ 3, 5, 25, 26; pl. 18

Stelechophyllum ascendens _-_---_--_----- 5, 10, 39

Siphonodendron

spiniformis, Lithostrotionella ______________ 36,39

Status of Lithostrotionella

stelcki, Lonsdaleia (Actinocyathus) 


Stelechophyllum
ascendens
$\quad$ ascendens
simplex

\section{$\mathrm{T}$}

Page.

tabulata, Lithostrotionella

tabulatum, Lithostrotion [Lithostrotionella] -26
tabulatus, Petalaxis

3,26

taishakuensis, Lithostrotionella Petalaxis $3,5,25,26,27$; pl. 19

Thysanophyllum $1,2,4,5,6,8,24,33,36,39$

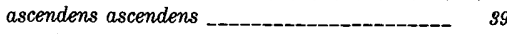
simplex

astraeiforme

orientale

(Thysanophyllum) astraeiformis, Lithostrotionell

[Thysanophyllum], Lithostrotion [Lithostrotionella mclareni, Lithostrotion [Lithostrotionella]

timanicus, Petalaxis

tingi, Lithostrotionella

tolmachevi, Stylophyllum

tschucotica, Lithostrotionella

tschucoticus, Petalaxis

tubifera, Aulina

Lithostrotion [Lithostrotionella] Lithostrotionella

tubiferus, Aulostylus

$3,5,7,15$

eotubiferus, Aulostylus _-______________ 3, 5, 15

tubiferus, Aulostylus

$3,4,7,15$

Tuscumbia Limestone 3,40

\section{$\mathrm{U}$}

uchtensis, Petalaxis

Undetermined lithostrotionelloid corals unica, Lithostrotionella

unicum, Lithostrotion (Lithostrotionella) Lithostrotionella

unicus, Acrocyath

U.S.S.R.

uralica, Kleopatrina

Kleopatrina (Kleopatrina)

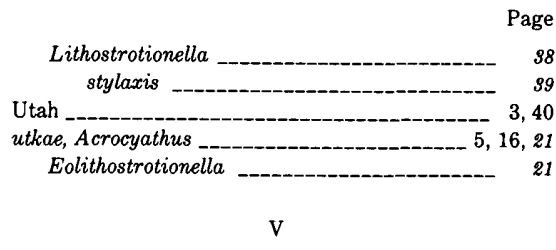

venukoffi, Stelechophyllum

S 5,11

Stylophyllum

altaicum, Stelechophyllum _._-_._-_._ 5, 7,

venukoffi, Stelechophyllum $\quad 5,11$

vesicularis, Lithostrotionella $\quad 3,18$

vesiculosa Lithostrotion [Lithostrotionella] _---_--

Lithostrotionella

vesiculosa

lisitchanskensis, Petalaxis

vesiculosa, Lithostrotionell

vesiculosus, Petalaxis

Virginia

ge 38

40 21

W

wagneri, Lithostrotionella (Hillia)

Petalaxis

wahooensis, Kleopatrina

Lithostrotionella

Weber Canyon, Utah

Formation $3,26,41$

West Virginia --_-_- 3

Wyoming - 3

wyomingensis, Petalaxis _-_-_-_-_3, 5, 25, 26, 27; pl. 18

Z

Zaphrentis

zhizhinae, Acrocyathus

Eolithostrotionella

5, 16,29 


\section{PLATES 1-20}

Contact photographs of the plates in this report are available, at cost, from U.S. Geological Survey Library,

Federal Center, Denver, Colorado 80225 


\section{PLATE 1}

[All figures $\times 4$ ]

Figures 1, 2. Stelechophyllum microstylum (White) (p. 11).

USNM 120244 (holotype of Lithostrotionella multiradiata Hayasaka). USGS loc. 490-PC, Lodgepole Limestone, Utah.

1. Longitudinal thin section, USNM $120244 \mathrm{~b}$.

2. Transverse thin section, USNM 120244a.

3, 4. Stelechophyllum microstylum (White) (p. 11).

USNM 162005 (paratype of Lithostrotionella multiradiata Hayasaka). USGS loc. 104-PC, Lodgepole Limestone, Idaho.

3 . Transverse thin section, USNM 162005a.

4. Longitudinal thin section, USNM $162005 \mathrm{~b}$. 

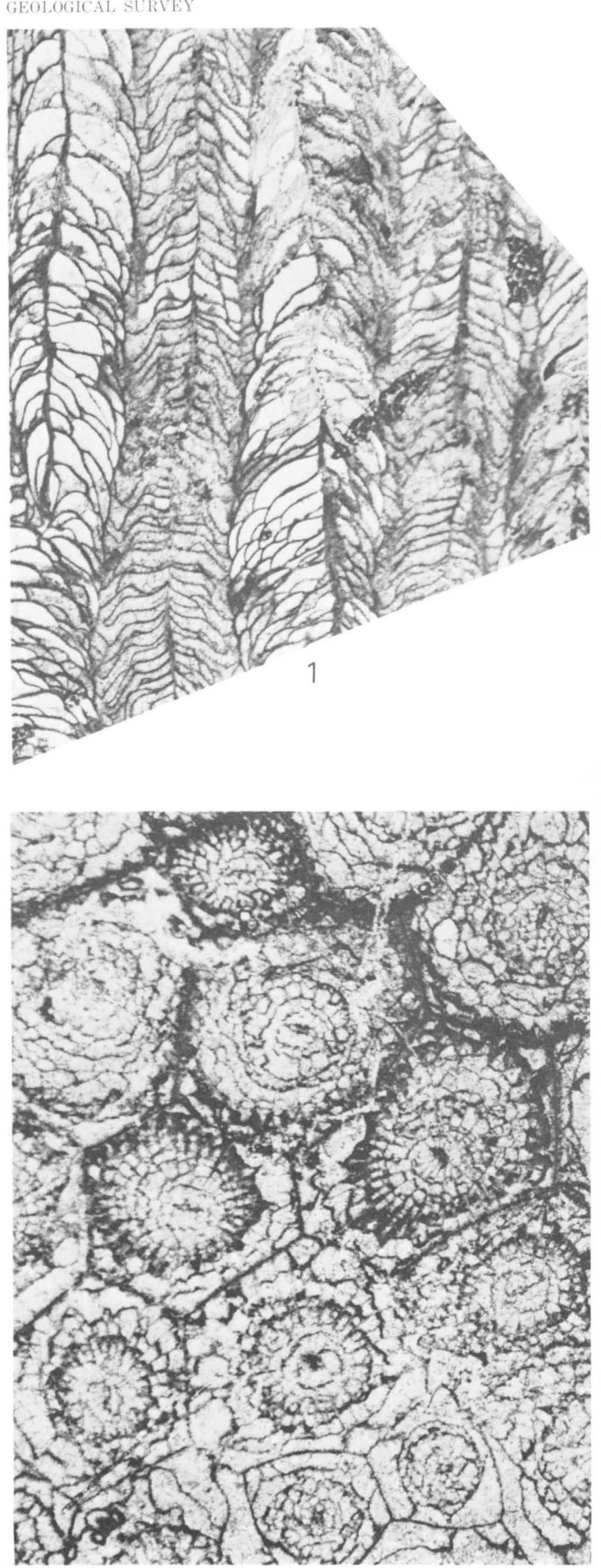

3

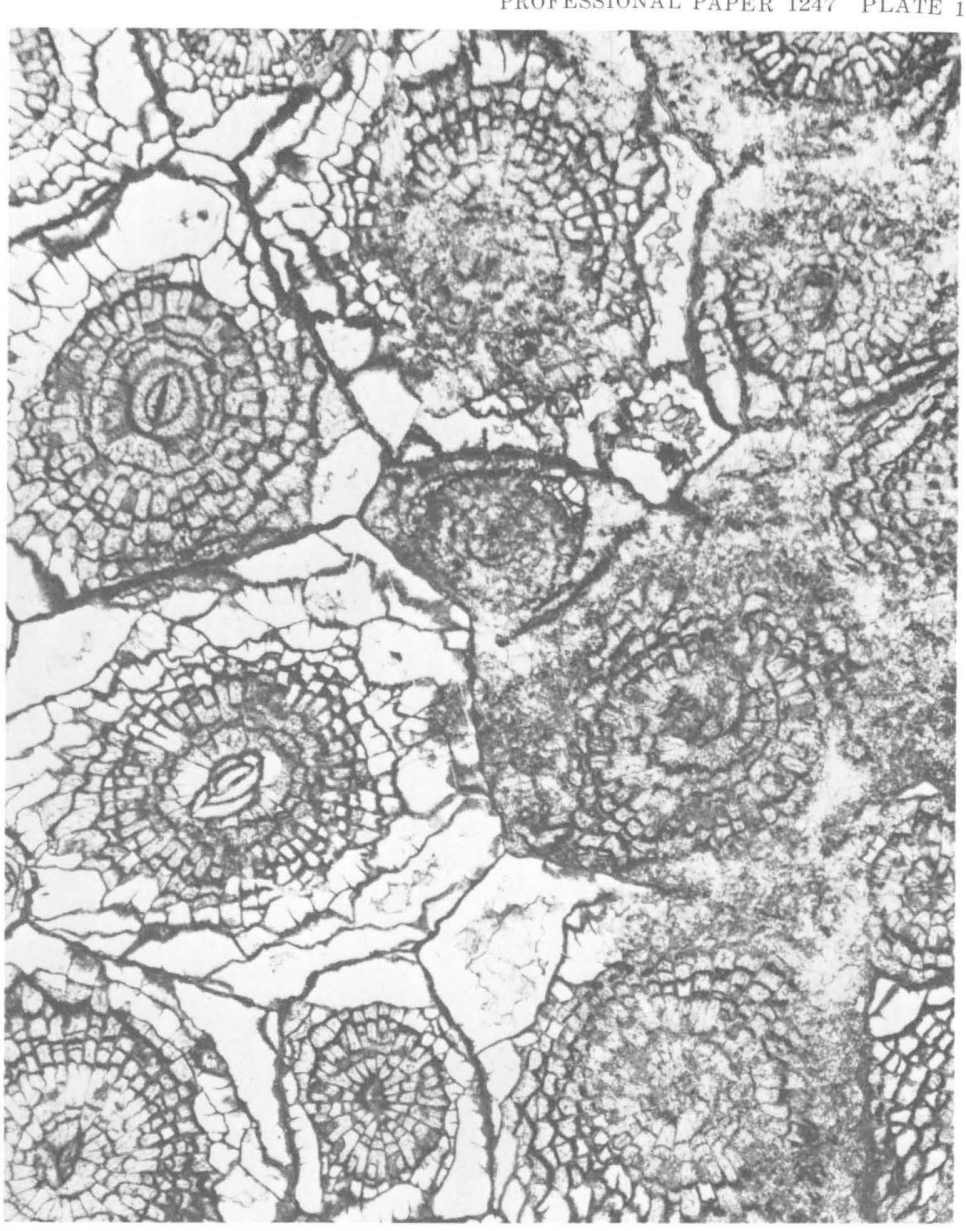

2

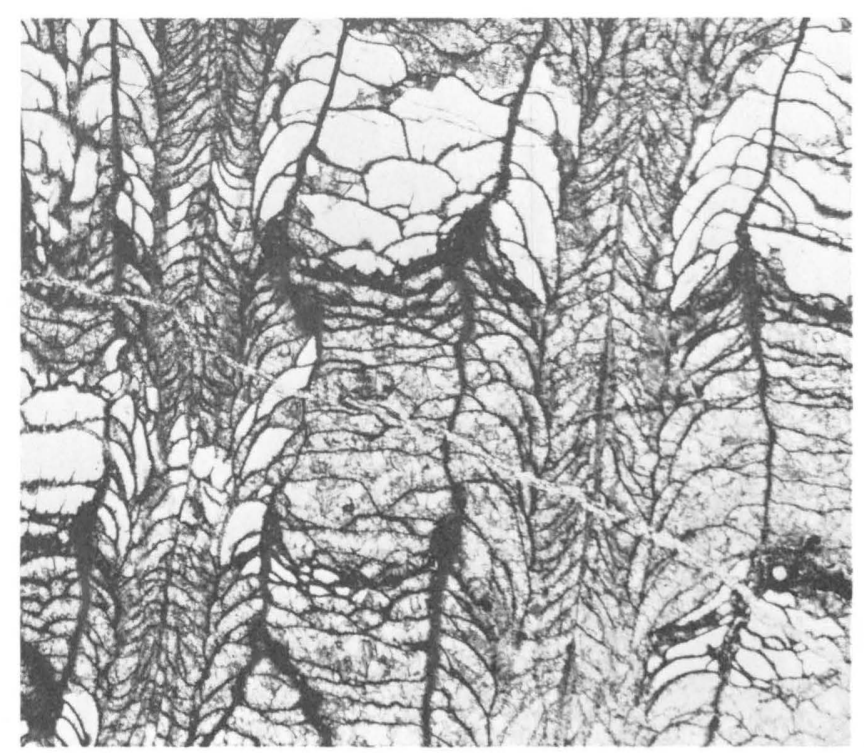

4

STELECHOPHYLLUM MICROSTYLUM (WHITE) 


\section{PLATE 2}

[All figures $\times 4$ ]

Figures 1, 2. Stelechophyllum microstylum (White) p. 11).

USNM 161996 (paratype of Lithostrotionella hemisphaerica Hayasaka). USGS loc. 1439-PC, Lodgepole Limestone, Idaho.

1. Transverse thin section, USNM 161996a.

2. Longitudinal thin section, USNM $161996 \mathrm{~b}$.

3. 4. Stelechophyllum microstylum (White)? (p. 11).

USNM 162003 (paratype of Lithostrotionella girtyi Hayasaka). USGS loc. 3864-PC, Lodgepole Limestone, Montana.

3. Transverse thin section, USNM 162003a.

4. Longitudinal thin section, USNM 162003c. 

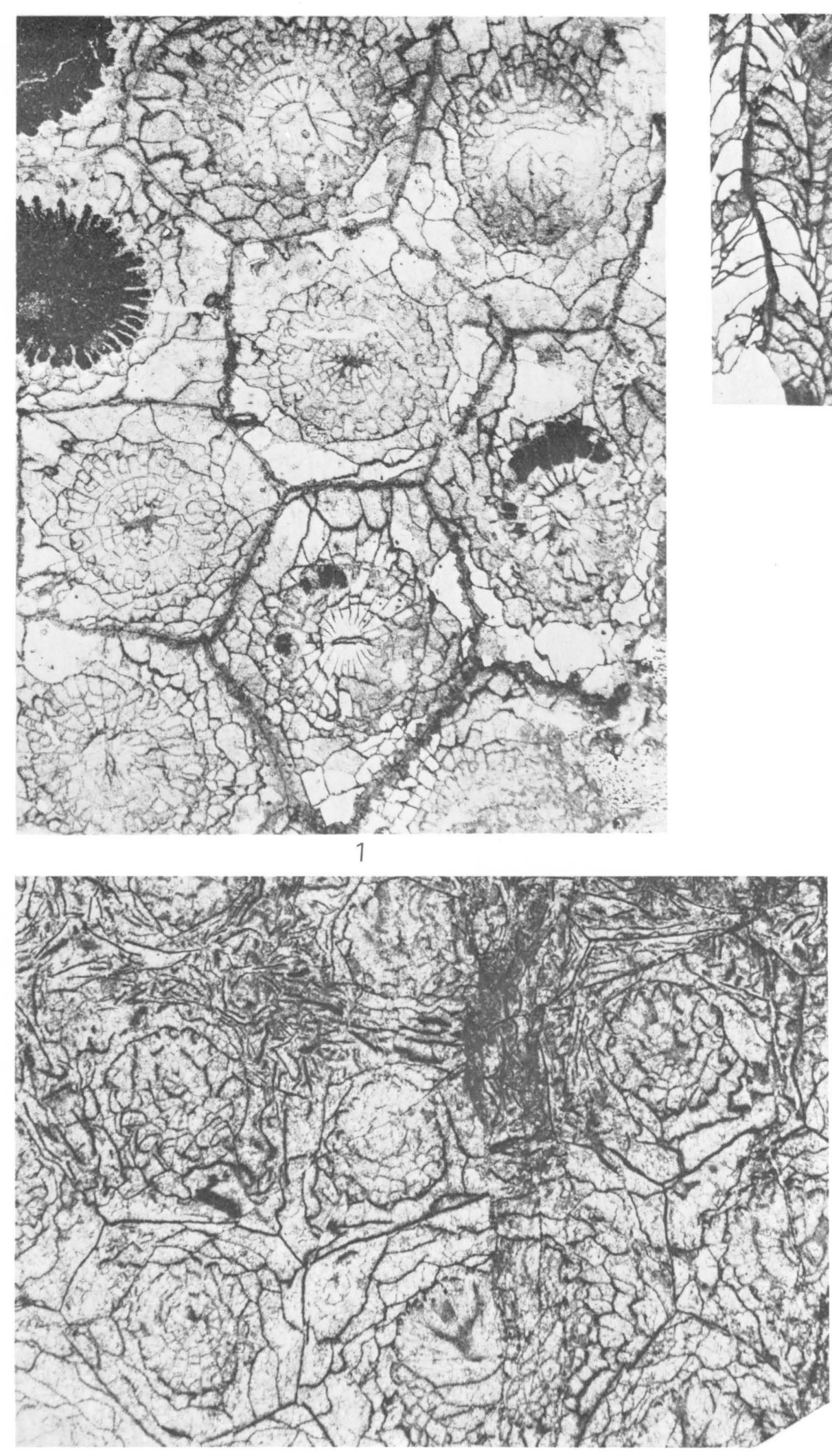

3

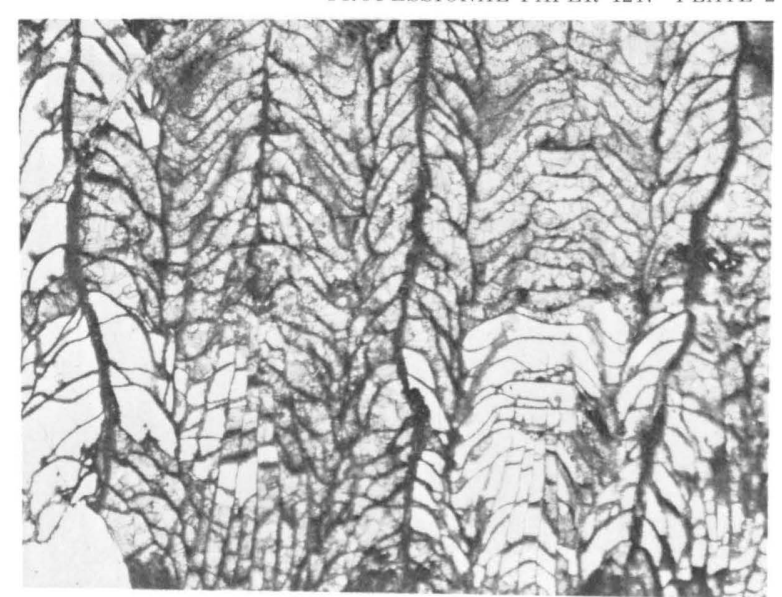

2

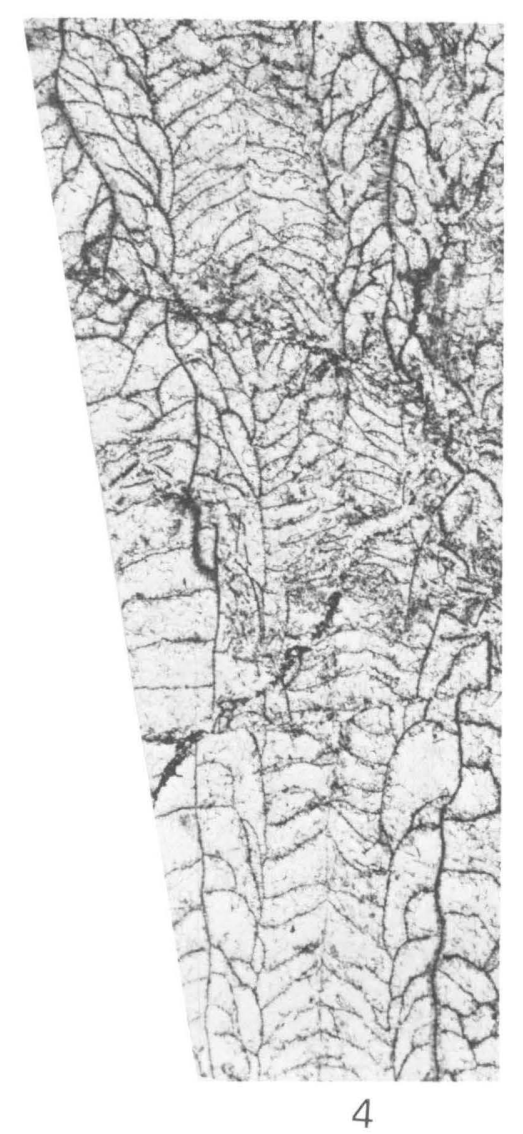

STELECHOPHYLLUM MICROSTYLUM (WHITE) 


\section{PLATE 3}

[All figures $\times 4]$

FIGURES 1, 2. Stelechophyllum banffense (Warren)? (p. 13).

USNM 174372 (paratype of Lithostrotionella americana Hayasaka). USGS Loc. 7130B-PC, Alapah Limestone(?), Alaska.

1. Transverse thin section, USNM 174372a.

2. Longitudinal thin section, USNM $174372 b$.

3, 4. Stelechophyllum banffense (Warren)? (p. 13).

USNM 174374 (paratype of Lithostrotionella americana Hayasaka). USGS Loc. 970-PC, Alapah Limestone(?), Alaska.

3 . Transverse thin section, USNM 174374a.

4. Longitudinal thin section, USNM $174374 \mathrm{~b}$. 


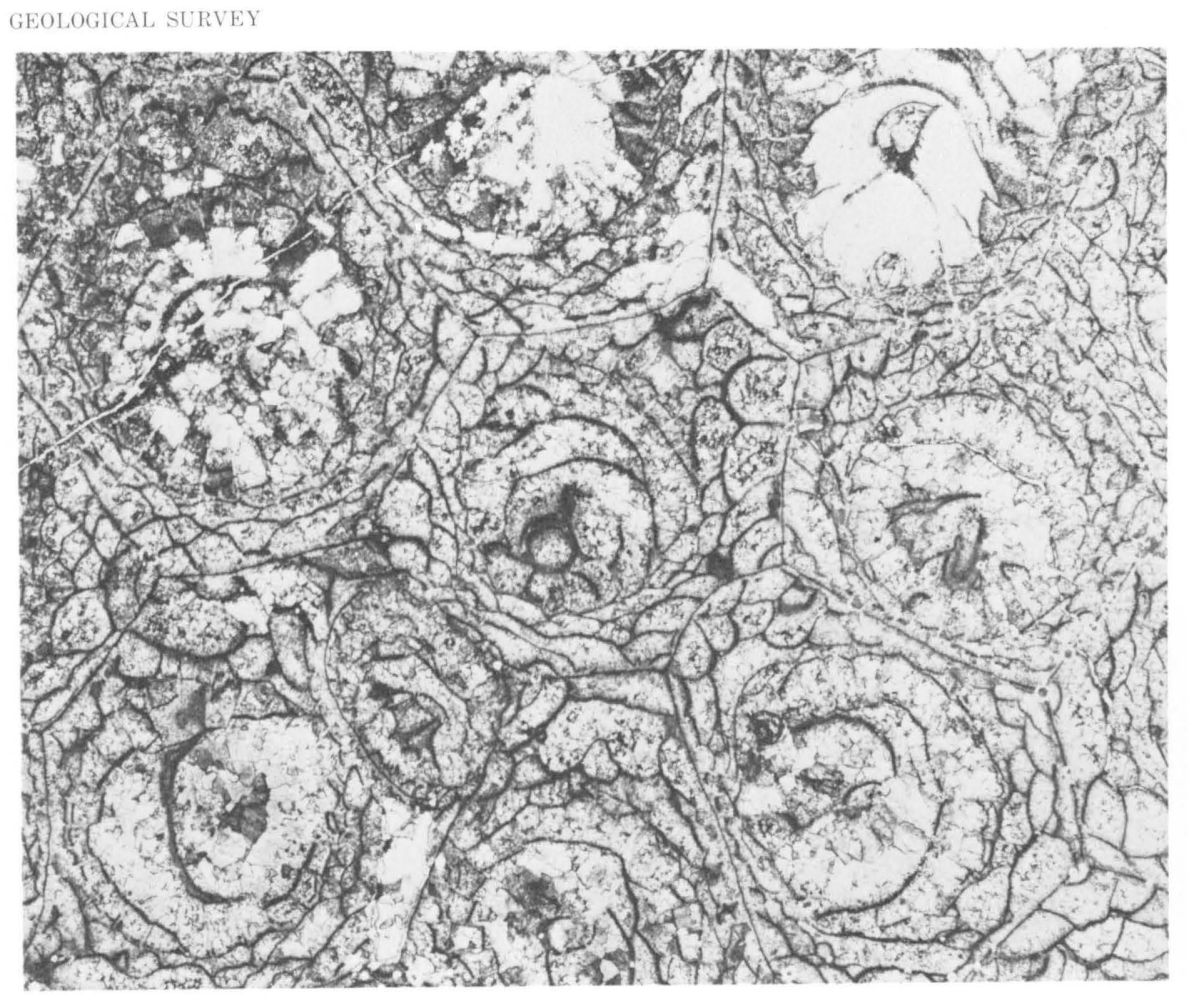

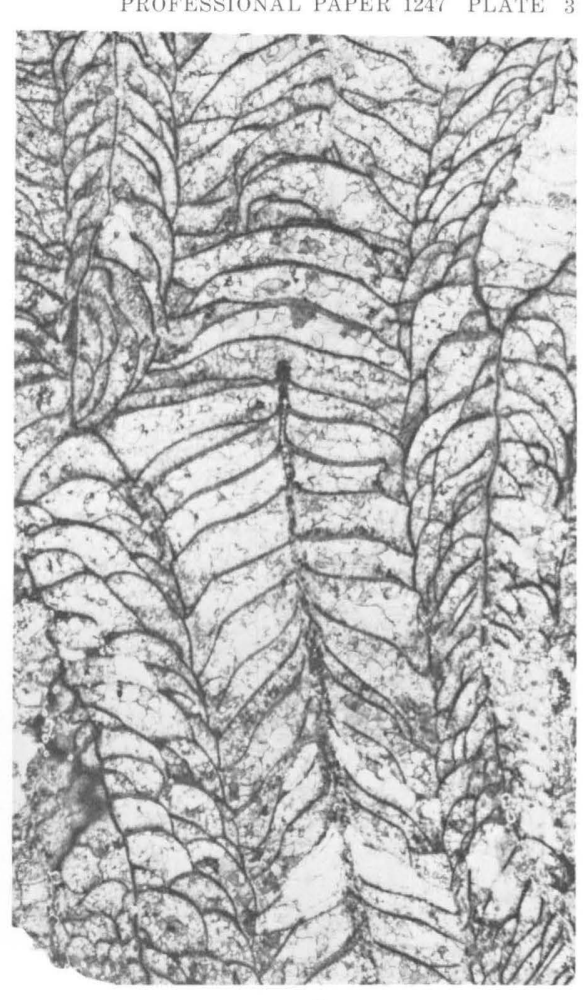

2

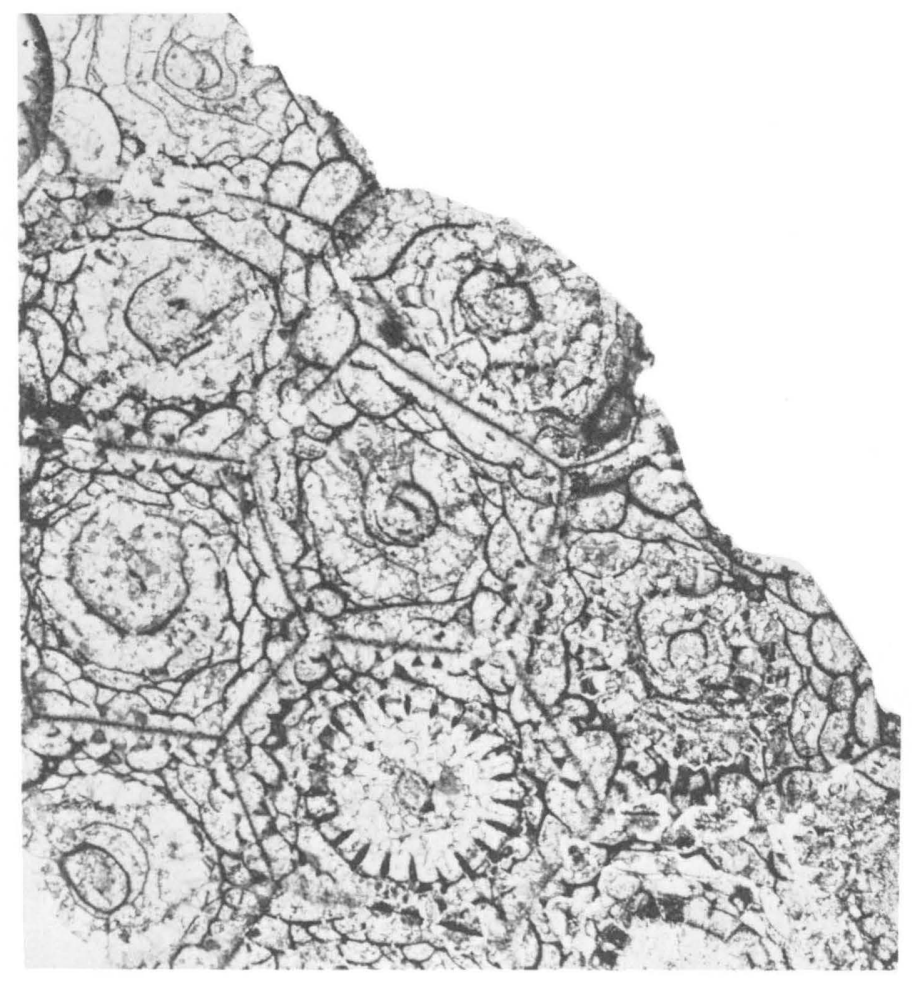

3

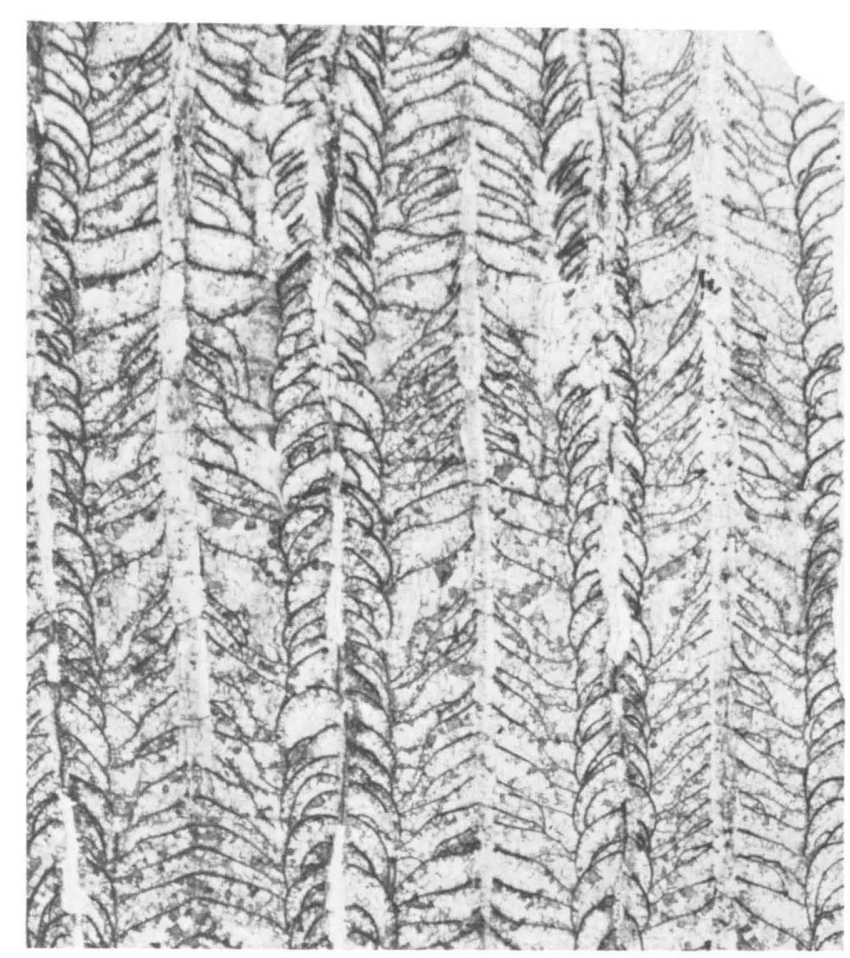

4

STELECHOPHYLLUM BANFFENSE (WARREN)? 


\section{PLATE 4}

[All figures $\times 4]$

Figures 1, 2. Stelechophyllum banffense (Warren)? (p. 13).

USNM 174375 (paratype Lithostrotionella americana Hayasaka). USGS Loc. 3024-PC, Little Flat Formation, Idaho.

1. Transverse thin section, USNM 174375a.

2. Longitudinal thin section, USNM 174375 c.

3, 4. Stelechophyllum sp. indet. (p. 15).

USNM 120239 (paratype of Lithostrotionella hemisphaerica Hayasaka). USGS Loc. 5892-PC, Madison Limestone, Utah.

3 . Longitudinal thin section, USNM 120239 c.

4. Transverse thin section, USNM 120239a. 
GEOLOGICAL SURVE)

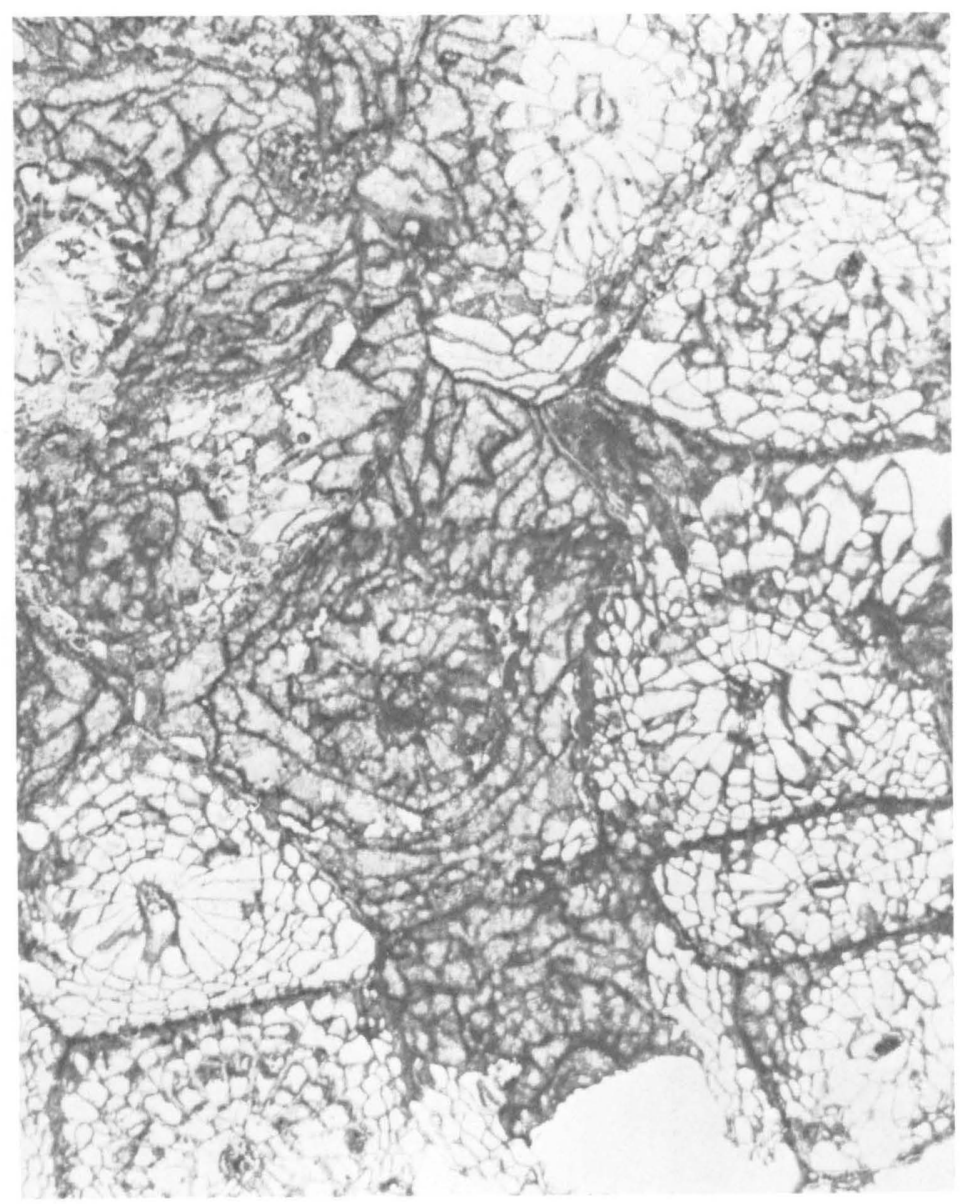

PROFESSIONAL PAPER 1247 PLATE 4

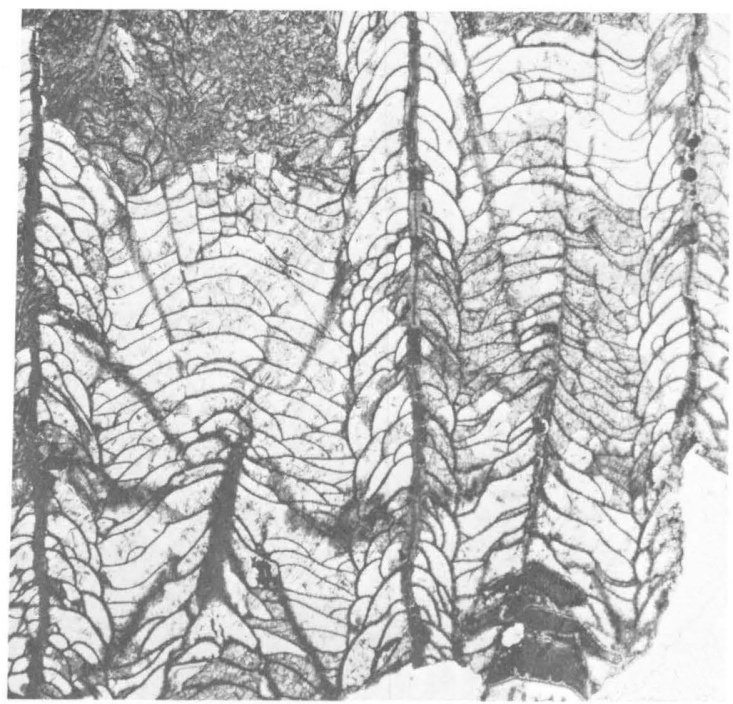

2

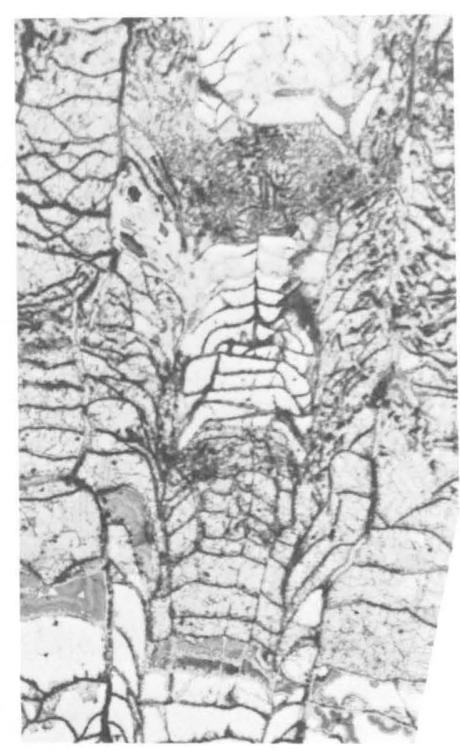

3

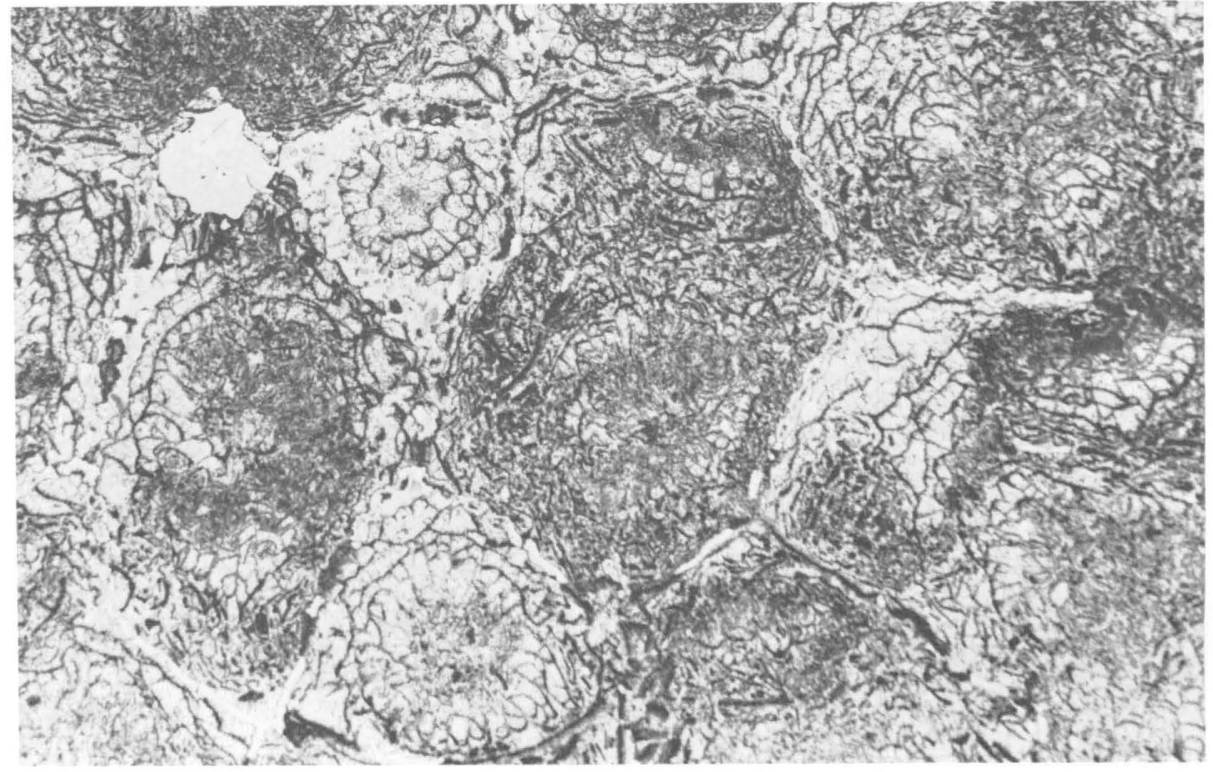

4

STELECHOPHYLLUM BANFFENSE (WARREN)? AND STELECHOPHYLLUM SP. INDET . 


\section{PLATE 5}

[All figures $\times 4$ ]

FIGURES 1, 2. Acrocyathus floriformis floriformis d'Orbigny (p. 17).

USNM 120240 (holotype of Lithostrotionella americana Hayasaka). USGS Loc. 2333-PC, St. Louis Limestone, Kentucky.

1. Transverse thin section, USNM 120240a.

2. Longitudinal thin section, USNM $120240 \mathrm{~b}$.

3, 4. Acrocyathus floriformis floriformis d'Orbigny (p. 17).

USNM 174376 (paratype of Lithostrotionella americana Hayasaka). USGS Loc. 499-PC, St. Louis Limestone, Illinois.

3. Longitudinal thin section (cut slightly off axis of corallite), USNM $174376 \mathrm{~b}$.

4. Transverse thin section, USNM 174376a. 


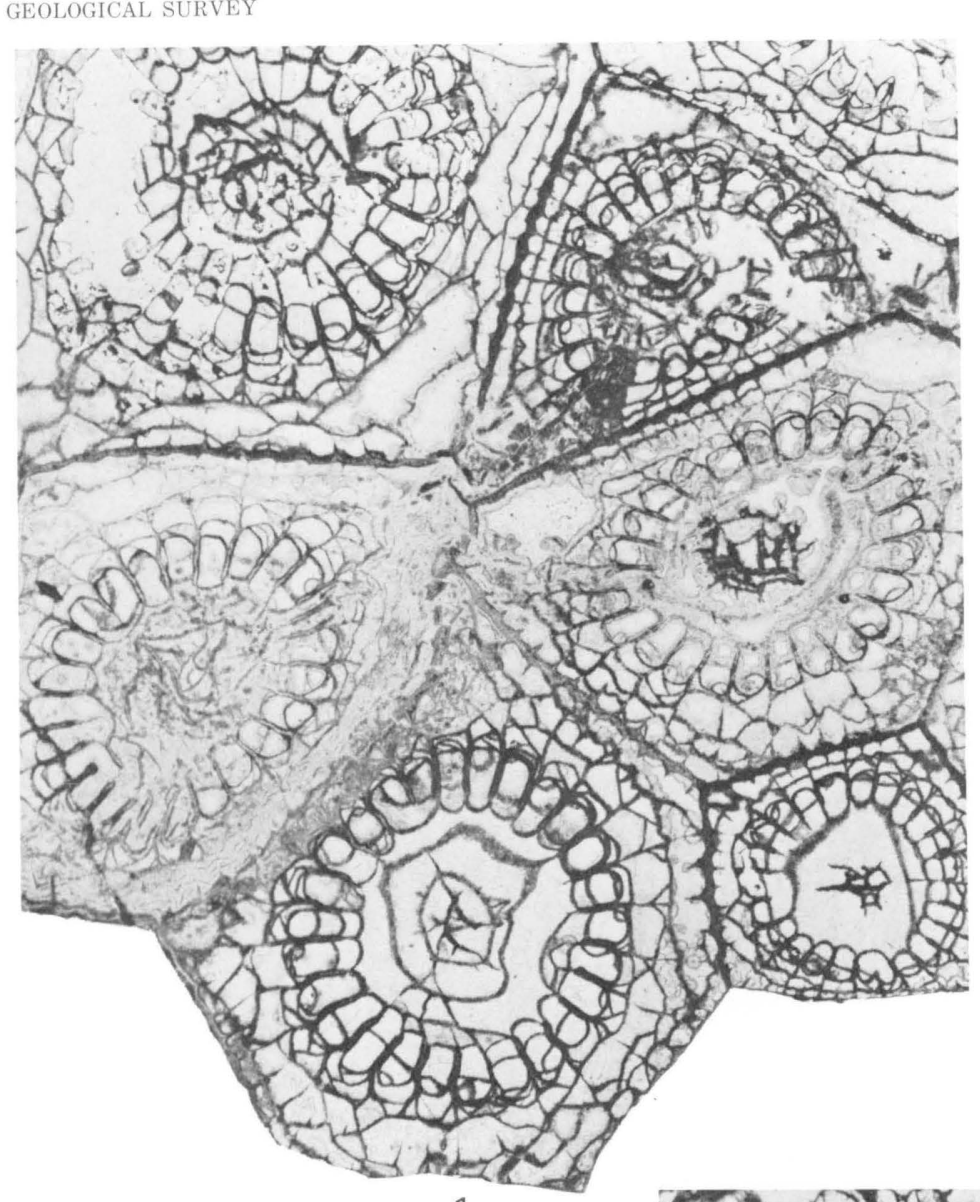

PROFESSIONAL PAPER 1247 PLATE 5
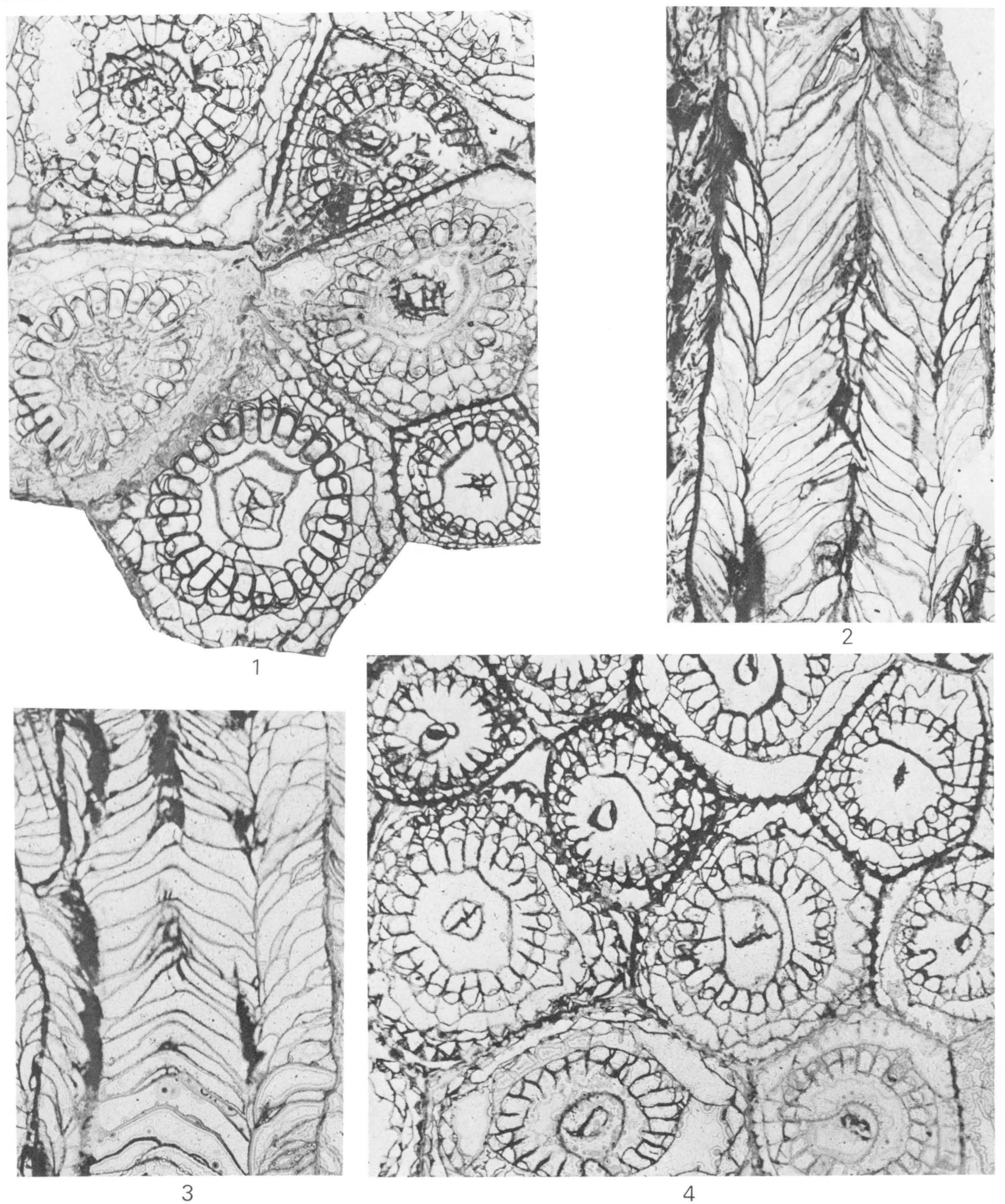

ACROCYATHUS FLORIFORMIS FLORIFORMIS D'ORBIGNY 


\section{PLATE 6}

[All figures $\times 4$ ]

FigURES 1, 2. Acrocyathus floriformis floriformis d'Orbigny? (p. 17).

USNM 162001 (paratype of Lithostrotionella americana Hayasaka). USGS Loc. 498-PC, St. Louis Limestone, Illinois.

1. Transverse thin section, USNM 162001a.

2. Longitudinal thin section, USNM $162001 \mathrm{~b}$.

3,4. Acrocyathus floriformis floriformis d'Orbigny? (p. 17).

USNM 120241 (paratype of Lithostrotionella americana Hayasaka). USGS Loc. 1211B-PC, St. Louis Limestone, Missouri.

Thysanophylloid variants in a polymorphic corallum.

3. Longitudinal thin section, USNM $120241 \mathrm{~b}$.

4. Transverse thin section, USNM 120241a. 
GEOLOGICAL SURVEY

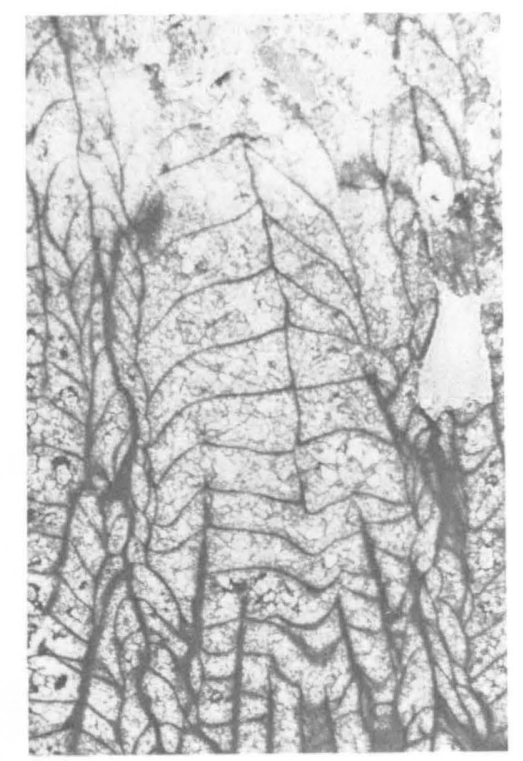

3
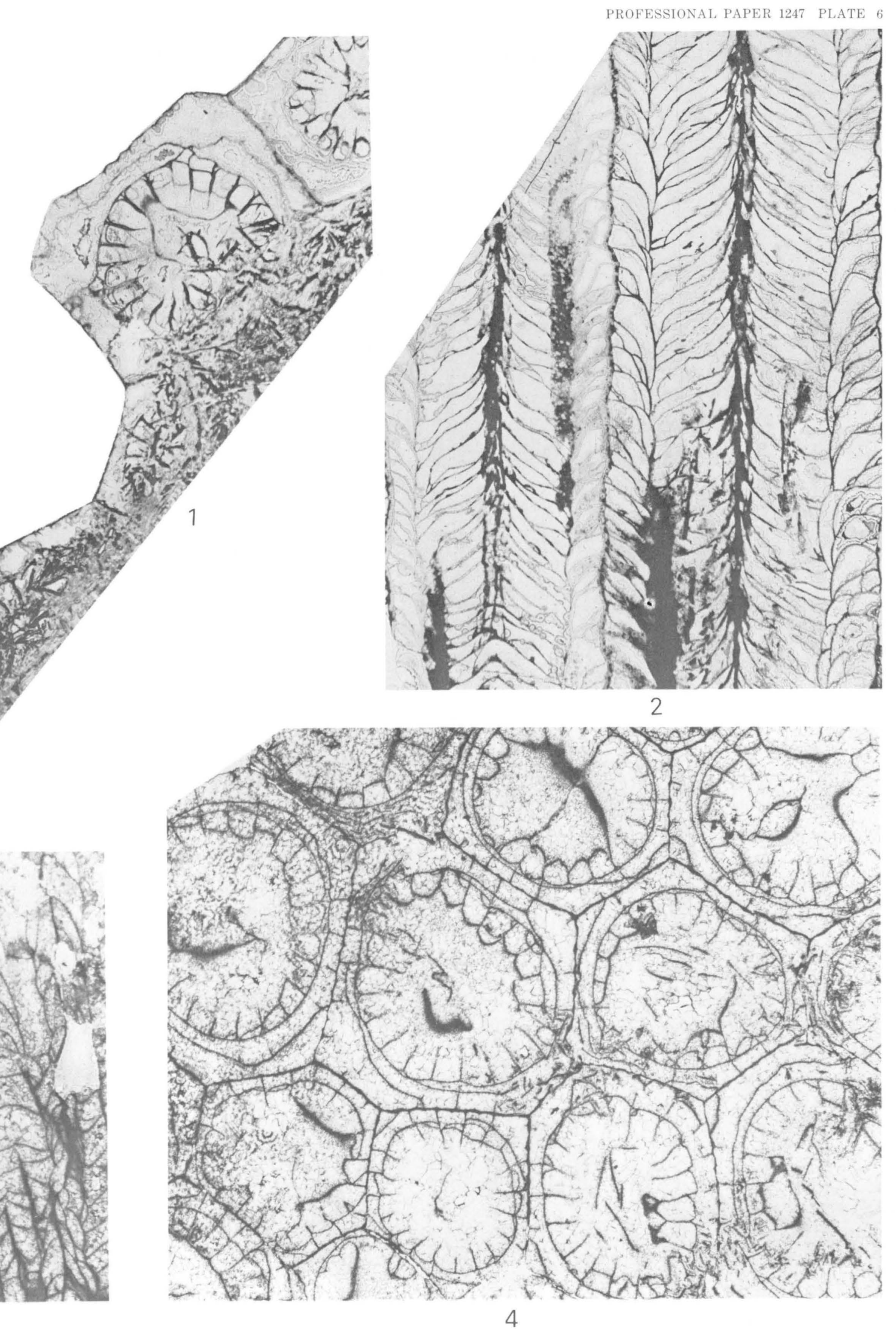

ACROCYATHUS FLORIFORMIS FLORIFORMIS D'ORBIGNY? 


\section{PLATE 7}

[All figures $\times 4$ ]

FIGURES 1,2. Acrocyathus floriformis floriformis d'Orbigny? (p. 17).

USNM 174377 (paratype of Lithostrotionella castelnaui Hayasaka). USGS 3946-PC (green), unknown locality, probably St. Louis Limestone, Mississippi Valley region.

1. Transverse thin section, USNM 174377a.

2. Longitudinal thin section (cut slightly off axis of corallite), USNM $174377 \mathrm{~b}$.

3, 4. Acrocyathus floriformis floriformis d'Orbigny (p. 17).

USNM 120235 (holotype of Lithostrotionella castelnaui Hayasaka). USGS Loc. 499-PC, St. Louis Limestone, Illinois.

3. Longitudinal thin section, USNM $120235 \mathrm{c}$.

4. Transverse thin section, USNM 120235a. 

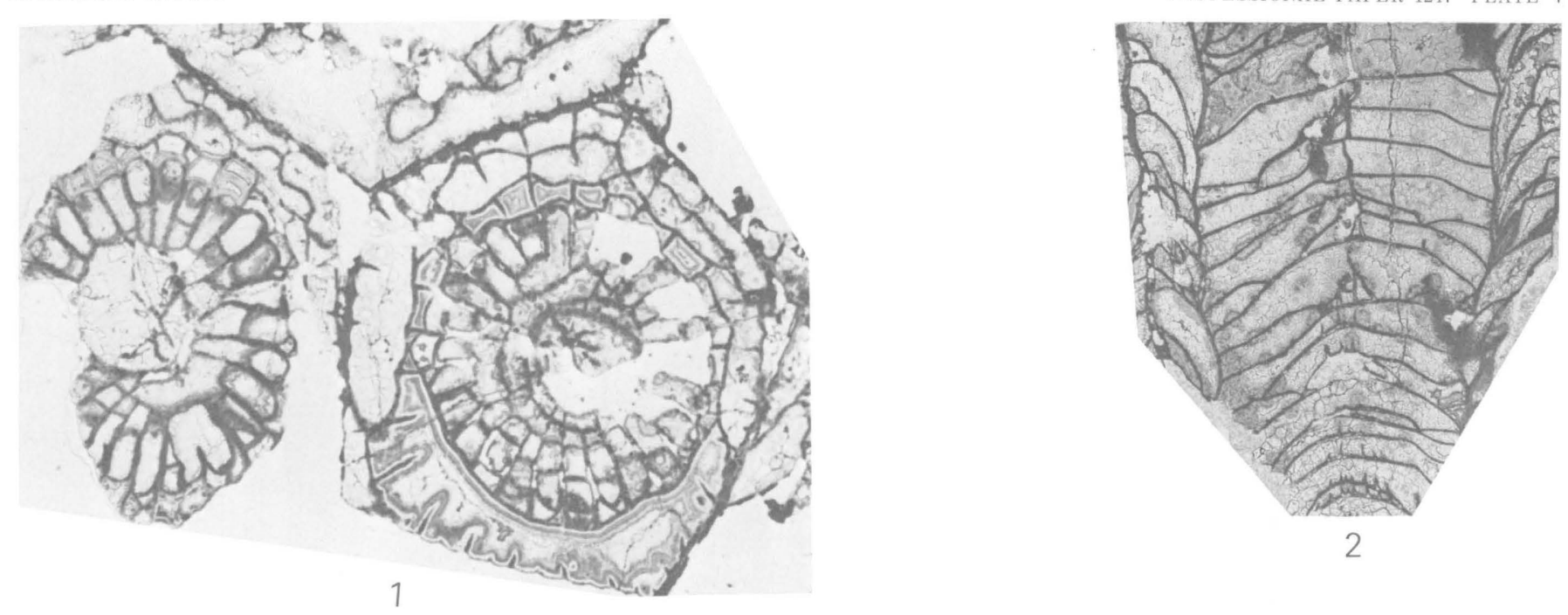

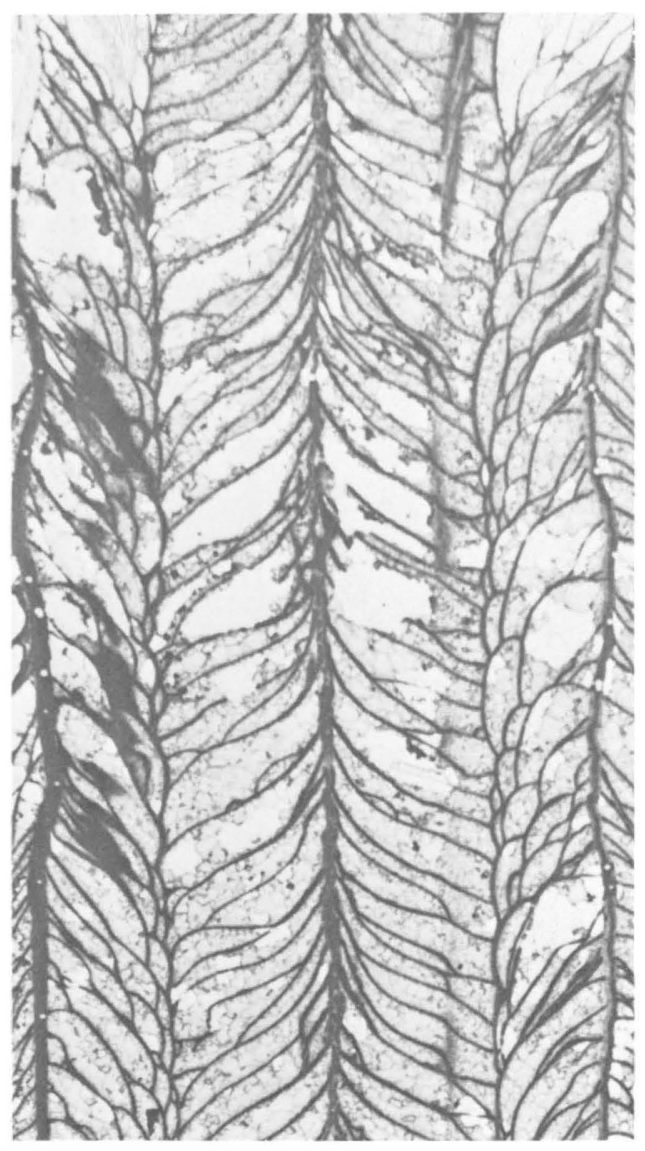

3

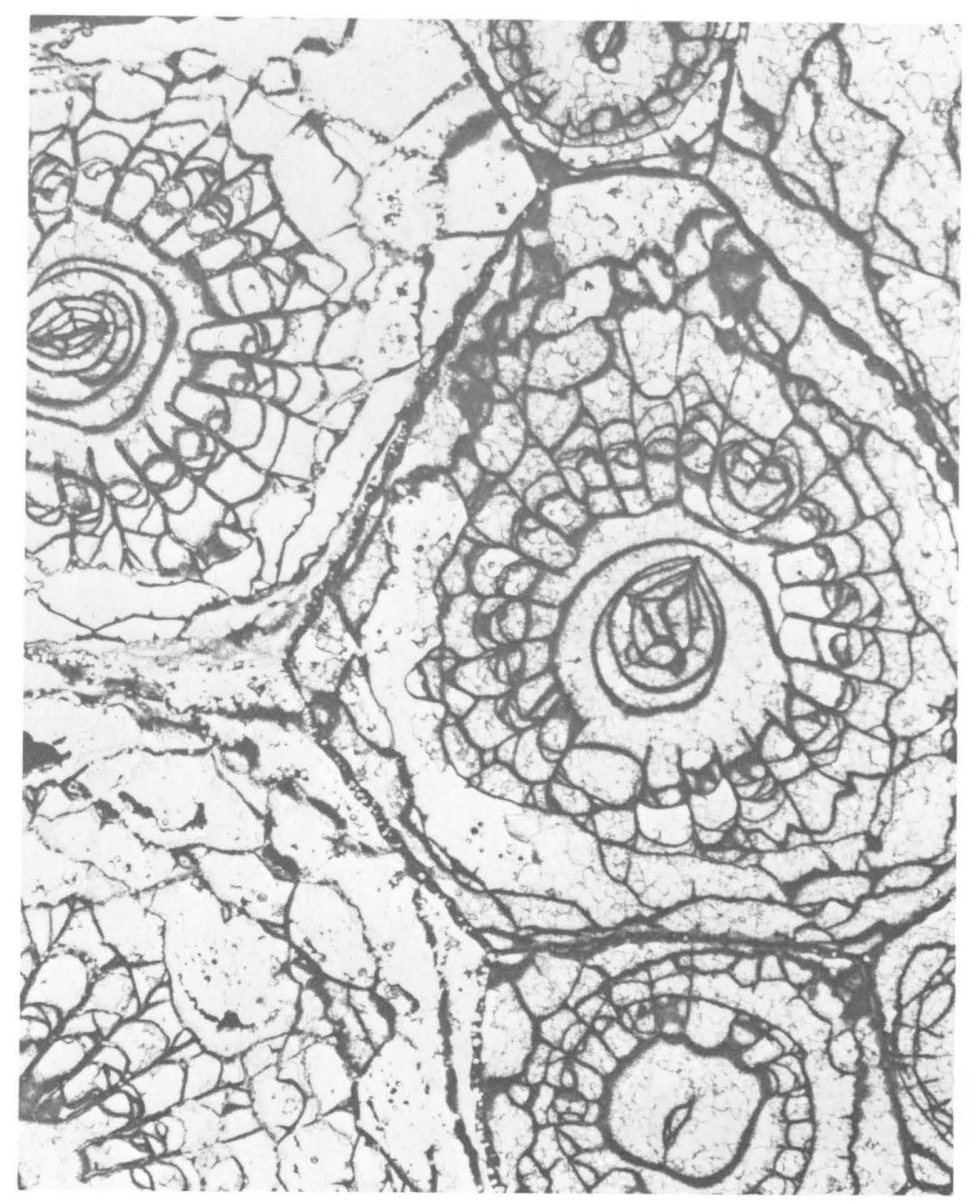

4

ACROCYATHUS FLORIFORMIS FLORIFORMIS D'ORBIGNY? AND ACROCYATHUS FLORIFORMIS FLORIFORMIS D'ORBIGNY 


\title{
PLATE 8
}

\author{
[All figures $\times 4$ ]
}

FiguREs 1, 2. Acrocyathus floriformis floriformis d'Orbigny (p. 17).

USNM 161991 (paratype of Lithostrotionella castelnaui Hayasaka). USGS Loc. 643-PC, St. Louis Limestone(?), Missouri.

1. Transverse thin section, USNM 161991a.

2. Longitudinal thin section, USNM 161991b.

3, 4. Acrocyathus floriformis floriformis d'Orbigny (p. 17).

USNM 161990 (paratype of Lithostrotionella castelnaui Hayasaka). USGS Loc. 346C-PC, residual chert from Tuscumbia Limestone, Alabama.

3. Longitudinal thin section, USNM 161990b.

4. Transverse thin section, USNM 161990 a. 
GEOLOGICAL SURVEY
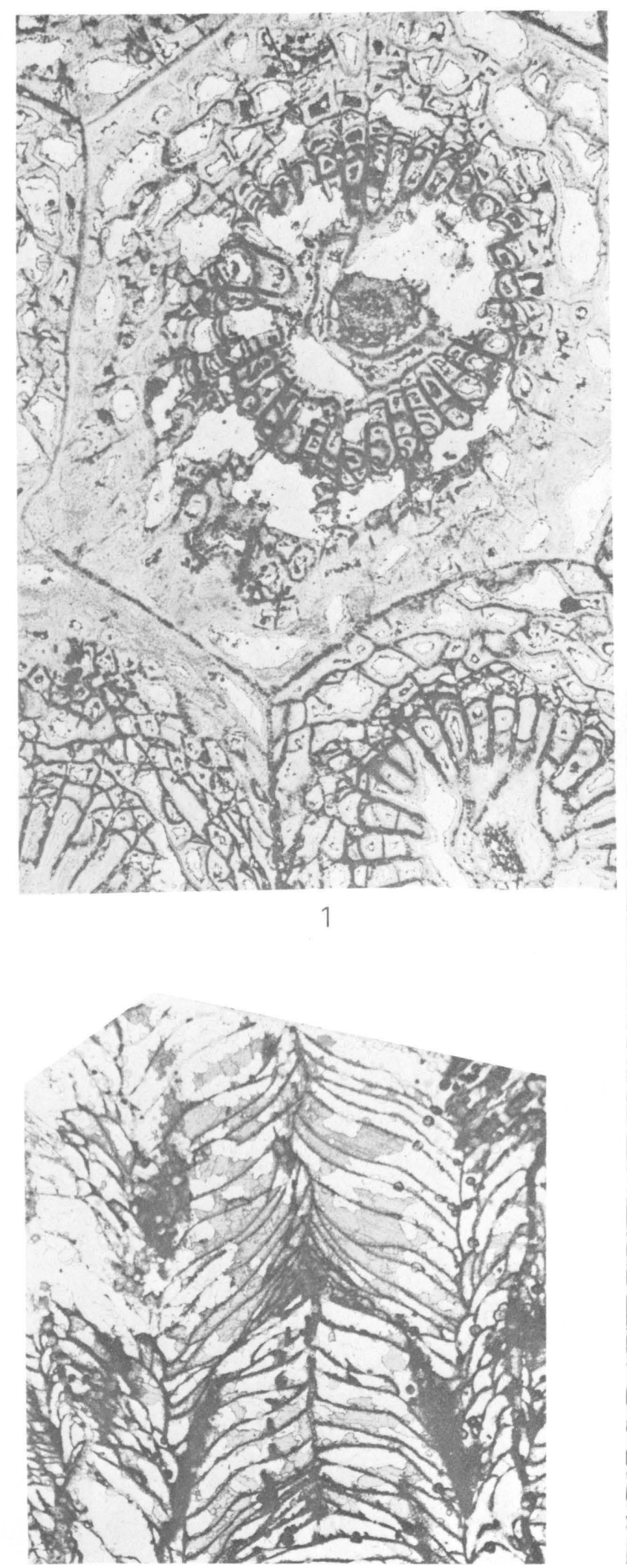

3

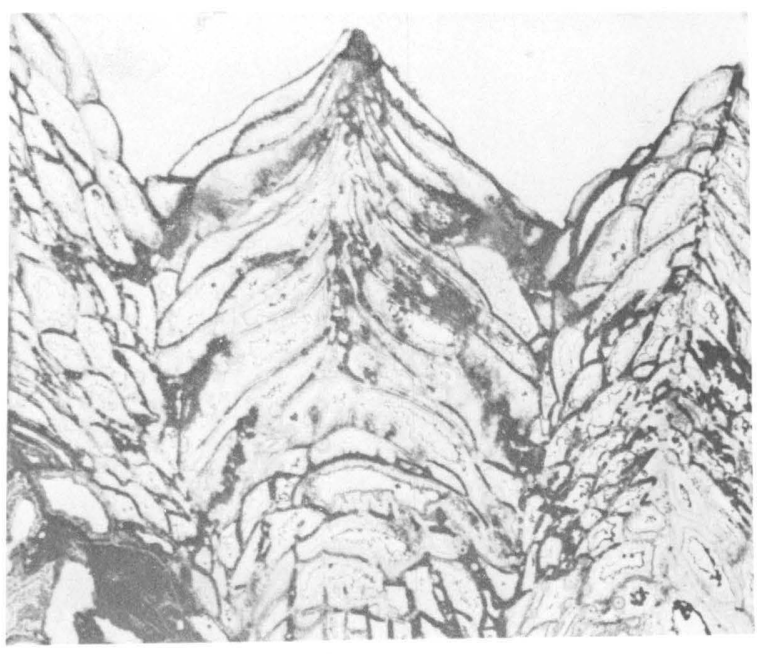

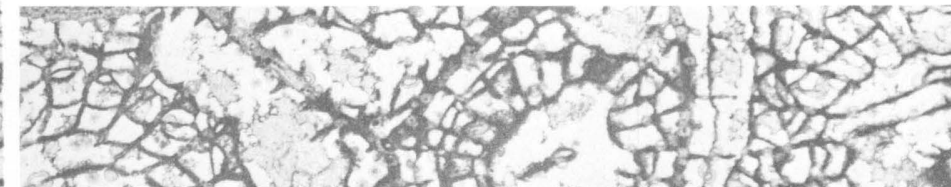
3.

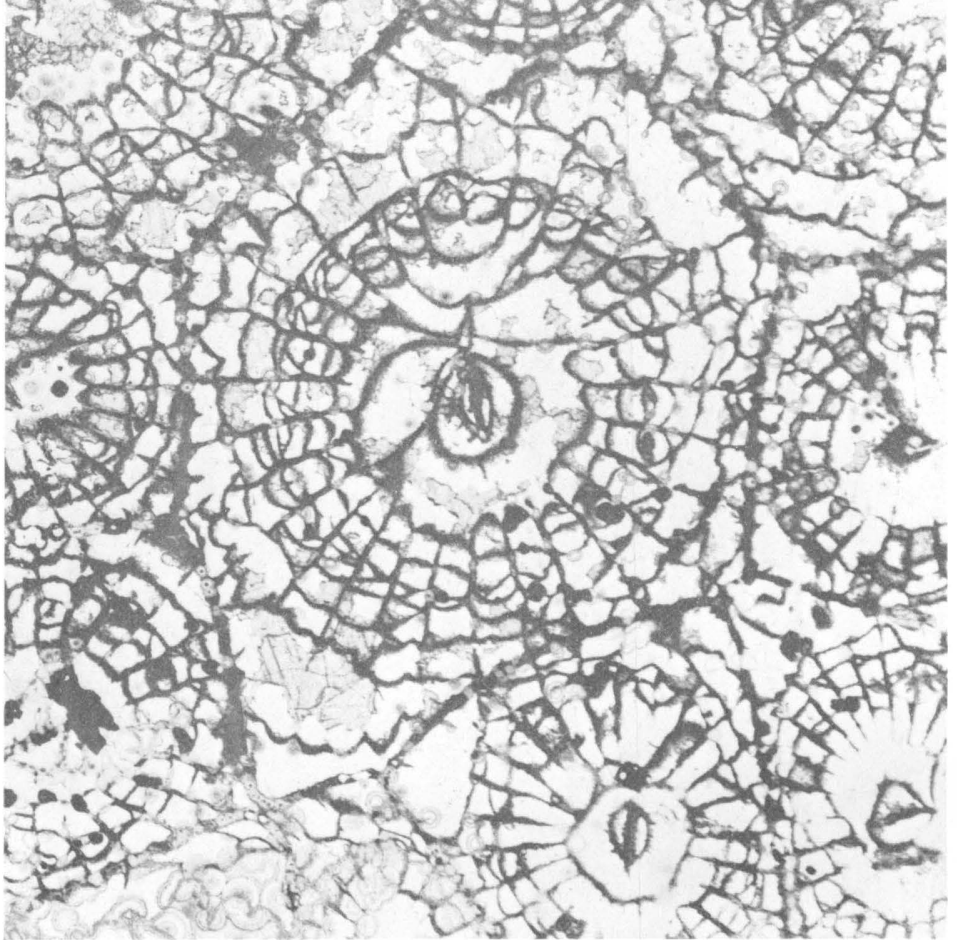
4

ACROCYATHUS FLORIFORMIS FLORIFORMIS D'ORBIGNY 


\section{PLATE 9}

[All figures $\times 4$ ]

FIgURES 1, 2. Acrocyathus floriformis floriformis d'Orbigny (p. 17).

USNM 161994 (paratype of Lithostrotionella castelnaui Hayasaka). USGS 2013B-PC, Greenbrier Limestone, Virginia.

1. Transverse thin section, USNM $161994 \mathrm{a}$.

2. Longitudinal thin section, USNM $161994 \mathrm{~b}$.

3, 4. Acrocyathus floriformis floriformis d'Orbigny (p. 17).

USNM 161989 (paratype of Lithostrotionella castelnaui Hayasaka). USGS Loc. 2226-PC, St. Louis Limestone, Illinois.

3 . Transverse thin section, USNM 161989a.

4. Longitudinal thin section, USNM 161989 c. 
¿EOLOGICAL SURVEY

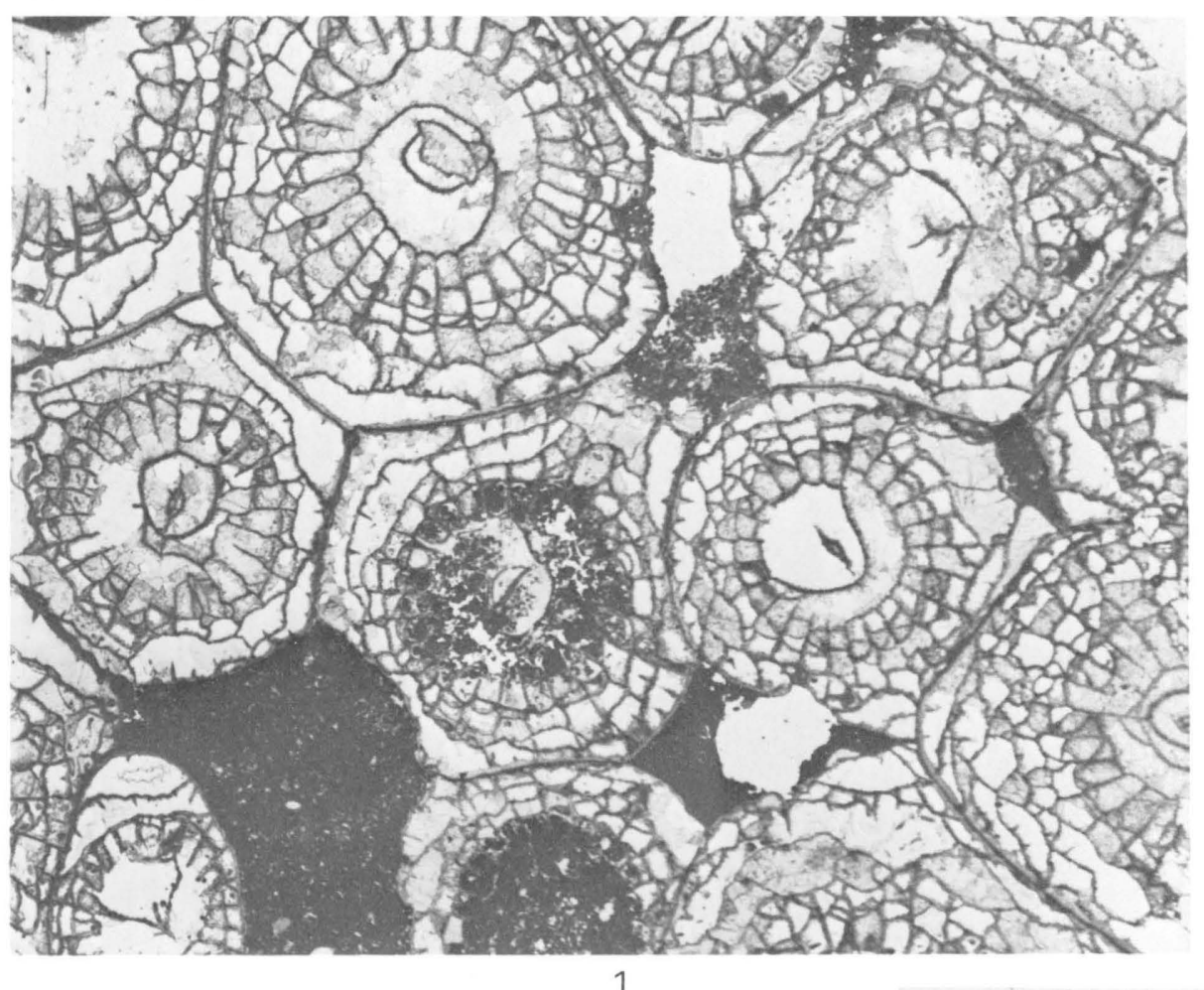

PROFESSIONAL PAPER 1247 PLATE 9

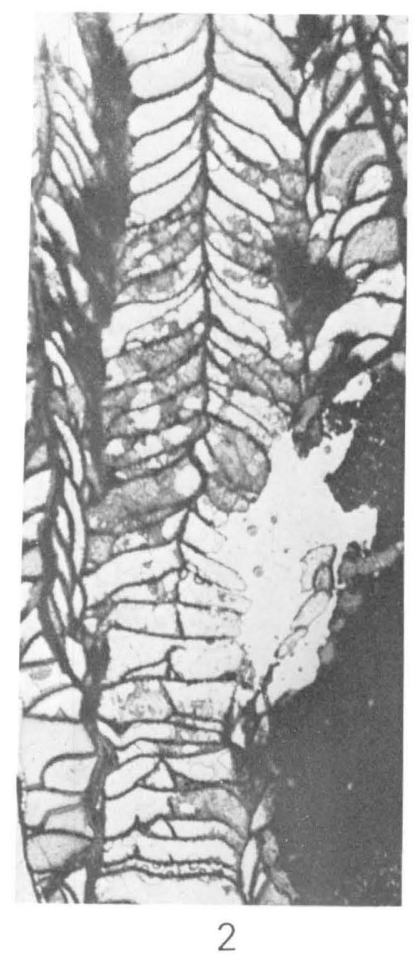

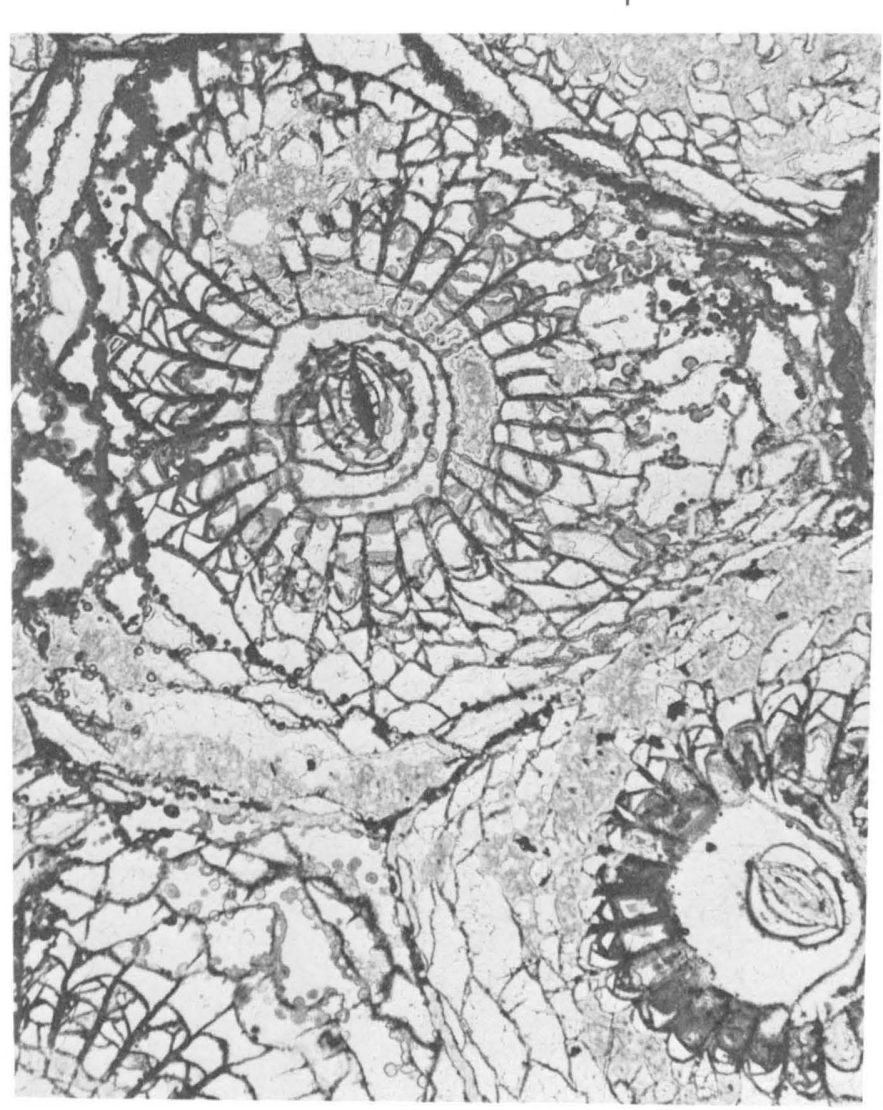
3

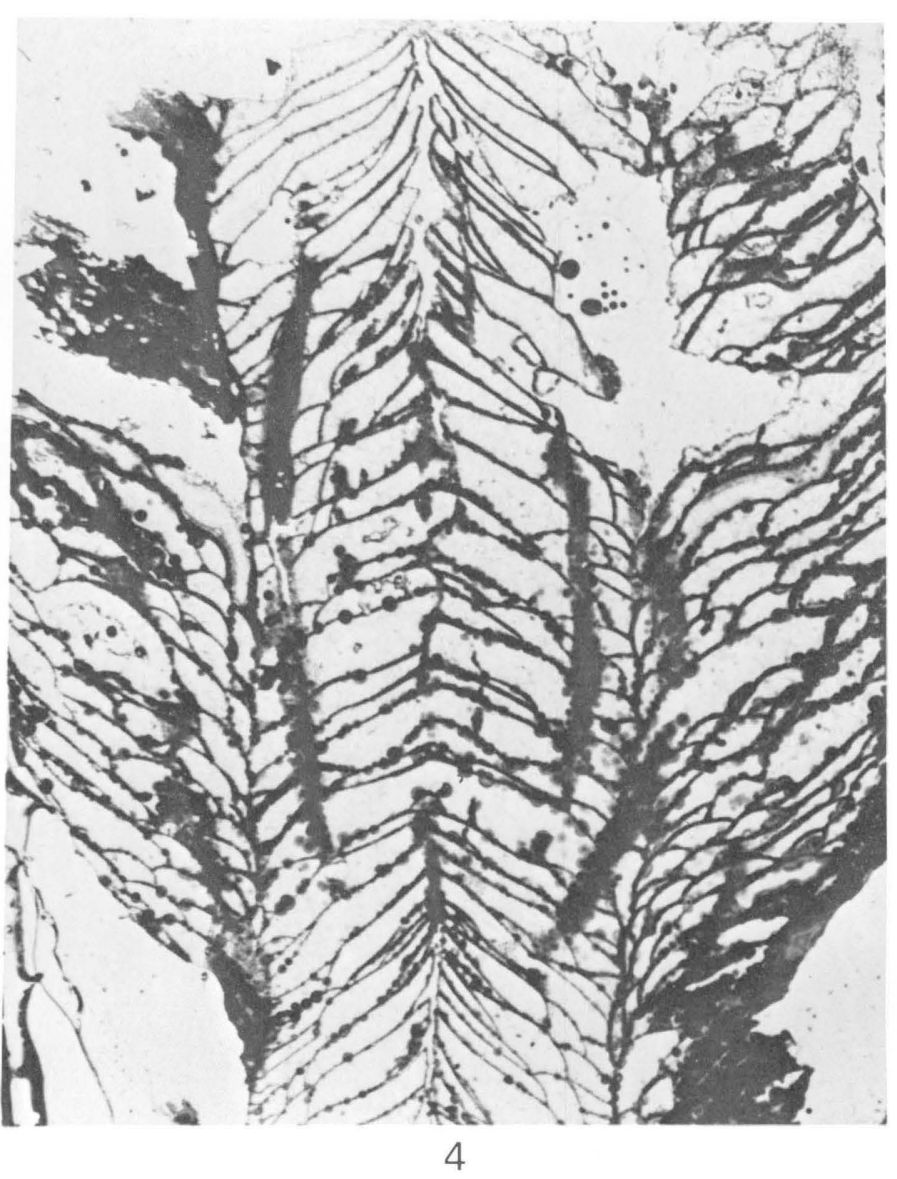

ACROCYATHUS FLORIFORMIS FLORIFORMIS D'ORBIGNY 


\title{
PLATE 10
}

\author{
[All figures $\times 4]$
}

FIGURES 1, 2. Acrocyathus floriformis floriformis d'Orbigny (p. 17).

USNM 161997 (paratype of Lithostrotionella hemisphaerica Hayasaka). USGS Loc. 2020-PC, Greenbrier Limestone, Virginia.

1. Transverse thin section, USNM 161997a.

2. Longitudinal thin section, USNM $161997 \mathrm{~b}$.

3, 4. Acrocyathus floriformis floriformis d'Orbigny (p. 17).

USNM 161993 (paratype of Lithostrotionella castelnaui Hayasaka). USGS Loc. 3159-PC, Newman Limestone, Virginia.

3. Longitudinal thin section, USNM 161993b.

4. Transverse thin section, USNM 161993a. 
GEOLOGICAL SURVEY
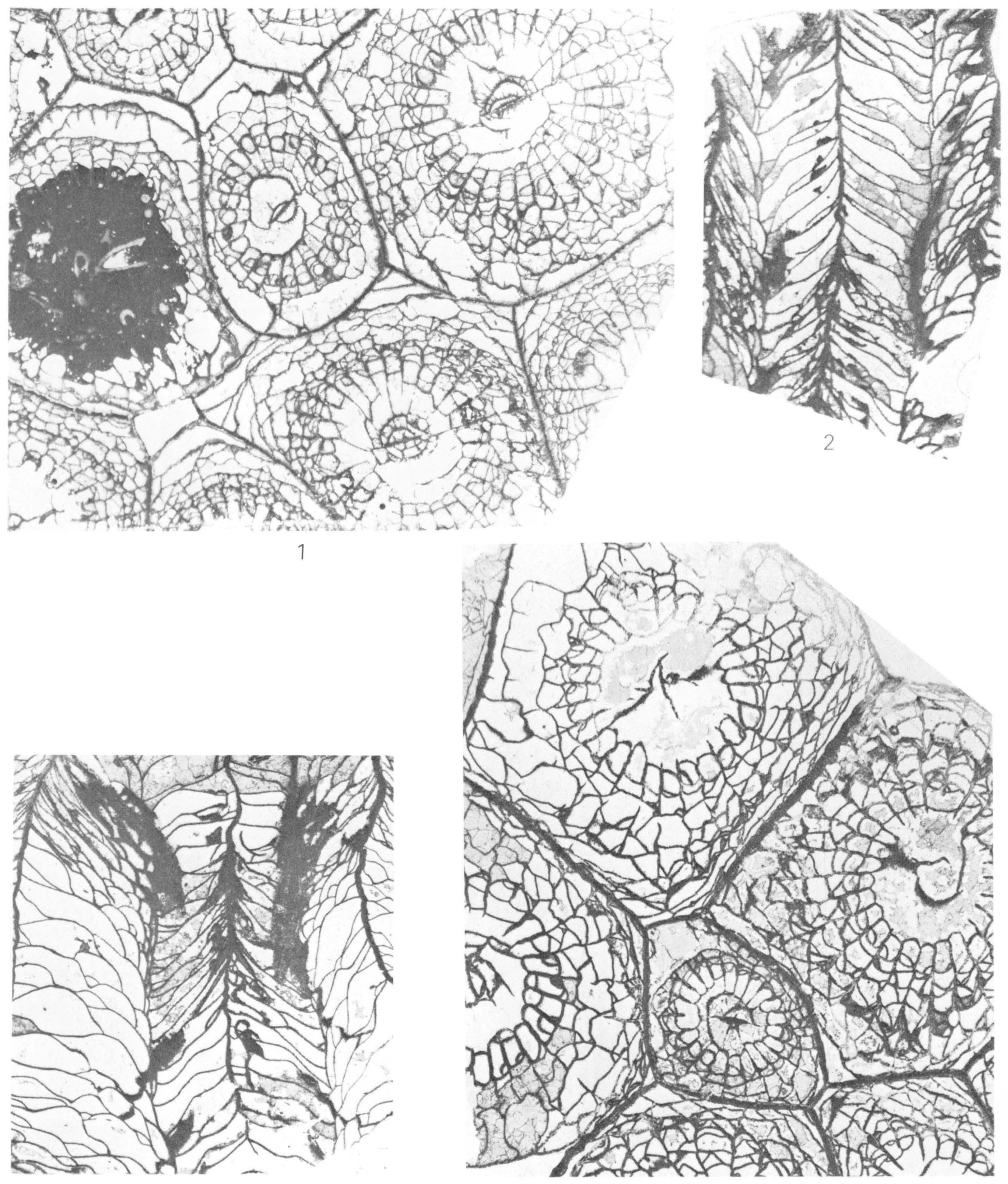

3 


\section{PLATE 11}

[All figures $\times 4]$

Figures 1,2. Acrocyathus floriformis floriformus d'Orbigny (p. 17).

USNM 161995 (paratype of Lithostrotionella hemisphaerica Hayasaka). USGS Loc. 83-PC, Newman Limestone, Kentucky.

1. Transverse thin section, USNM 161995a.

2. Longitudinal thin section, USNM $161995 \mathrm{~b}$.

3, 4. Acrocyathus floriformis floriformis d'Orbigny (p. 17).

USNM 120238 (paratype of Lithostrotionella hemisphaerica Hayasaka). USGS Loc. 3283-PC, Hillsdale Member of Greenbrier Limestone, West Virginia.

3. Longitudinal thin section, USNM 120238d.

4. Transverse thin section, USNM $120238 \mathrm{~b}$. 

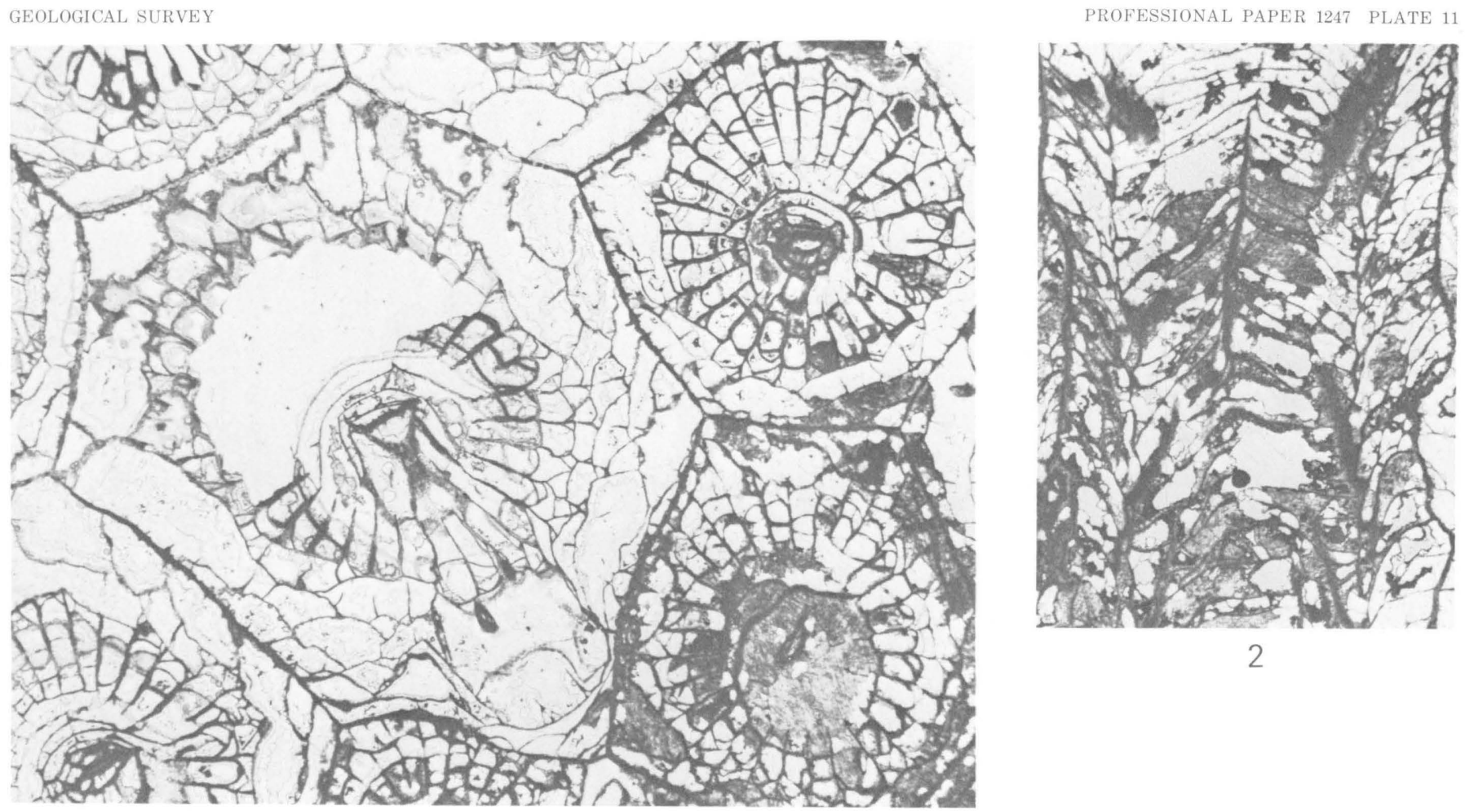

2

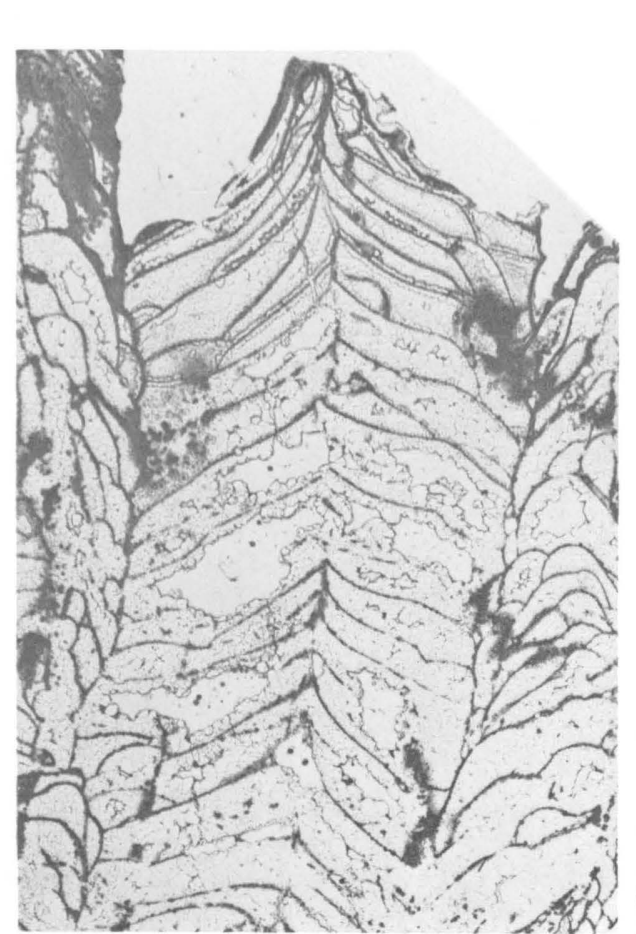

3

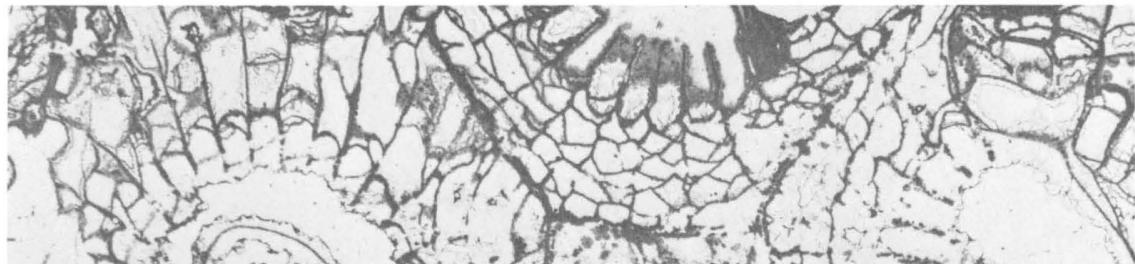
D mat

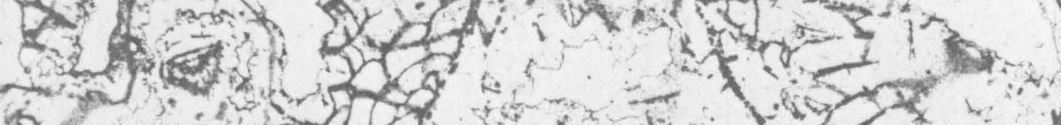

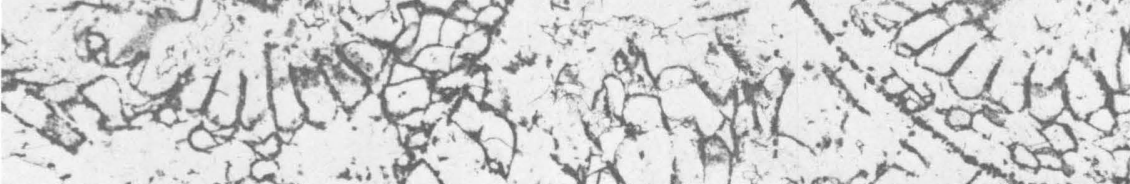

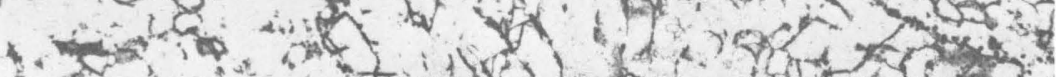
to

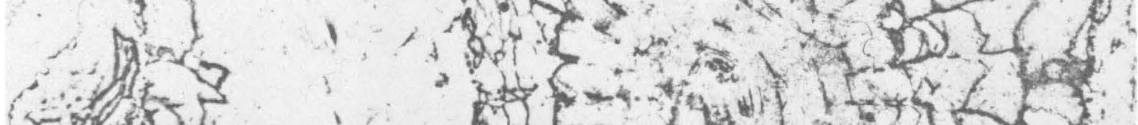

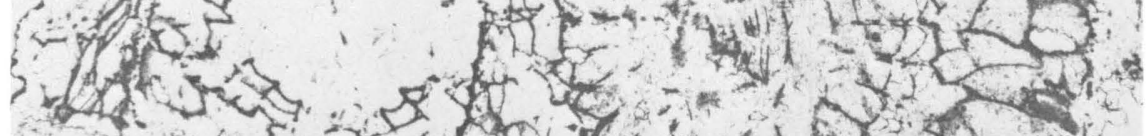

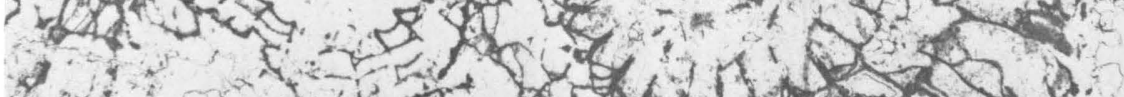

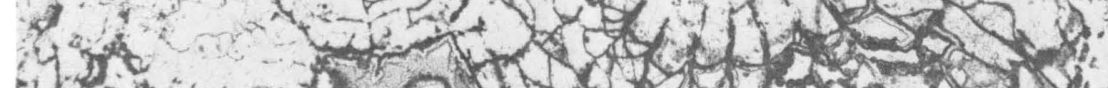

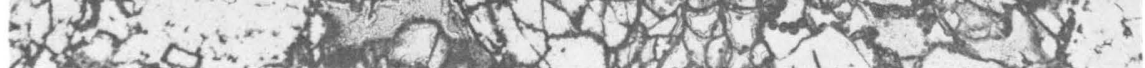




\section{PLATE 12}

\section{[All figures $\times 4]$}

FIgURES 1, 2. Acrocyathus floriformis hemisphaericus (Hayasaka) (p. 19).

Holotype, USNM 120237. USGS Loc. 1148-PC, St. Louis Limestone, Illinois.

1. Transverse thin section, USNM 120237a.

2. Longitudinal thin section, USNM $120237 \mathrm{c}$.

3, 4. Acrocyathus floriformis hemisphaericus (Hayasaka) (p. 19).

Paratype, USNM 161998. USGS Loc. 932A-PC, St. Louis Limestone, Missouri.

3. Longitudinal thin section, USNM $161998 \mathrm{~b}$.

4. Transverse thin section, USNM 161998a. 

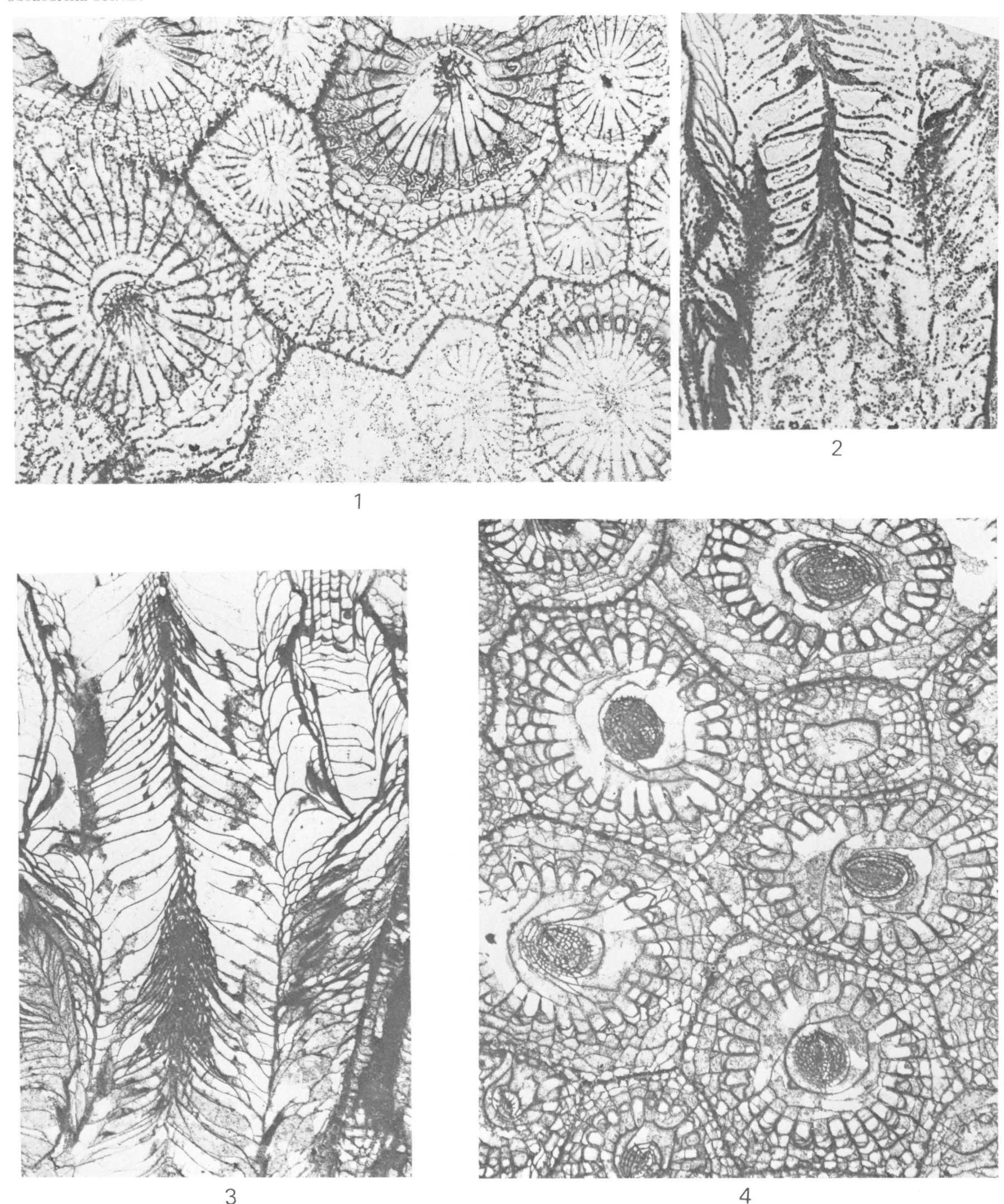

ACROCYATHUS FLORIFORMIS HEMISPHAERICUS (HAYASAKA) 


\title{
PLATE 13
}

\author{
[All figures $\times 4$ ]
}

FIGURES 1, 2. Acrocyathus floriformis hemisphaericus (Hayasaka) (p. 19).

Paratype, USNM 161999. USGS Loc. 2222A-PC, St. Louis Limestone, Illinois.

1. Transverse thin section, USNM 161999a.

2, 3. Longitudinal thin section, USNM $161999 \mathrm{~b}$.

4-6. Acrocyathus floriformis hemisphaericus (Hayasaka)? (p. 19).

Paratype, USNM 162000. USGS Loc. 2222C-PC, St. Louis Limestone, Illinois.

4, 5. Longitudinal thin section, USNM $162000 \mathrm{~b}$.

6. Transverse thin section, USNM 162000a. 
GEOLOGICAL SURVEY

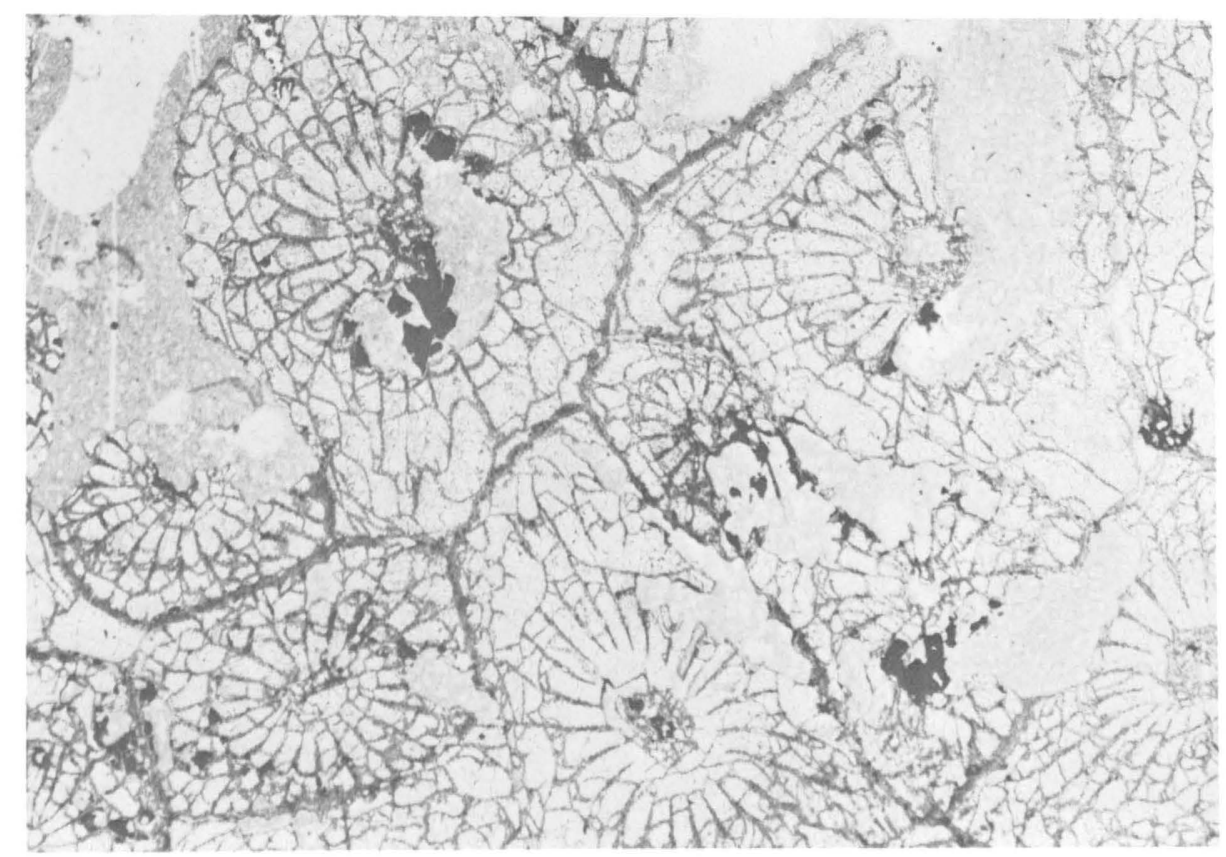

1
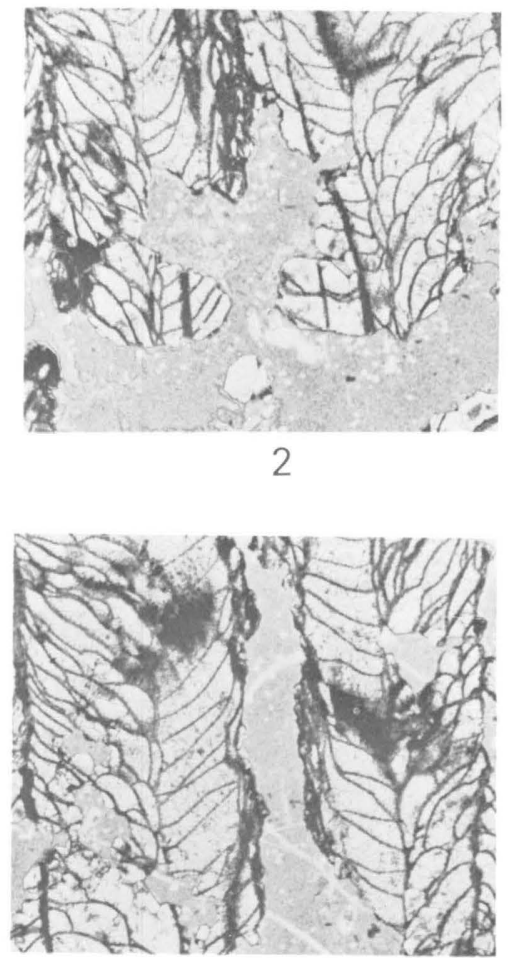

3

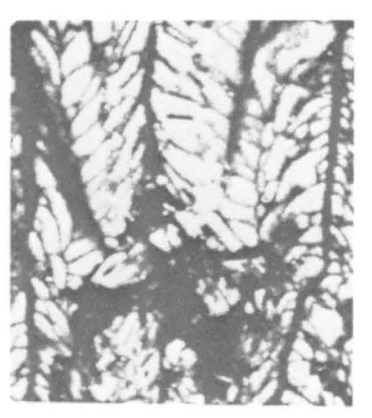

4

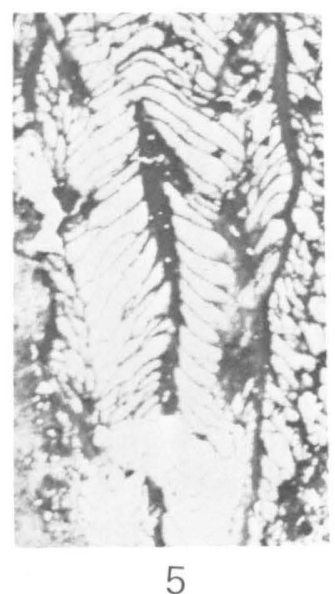

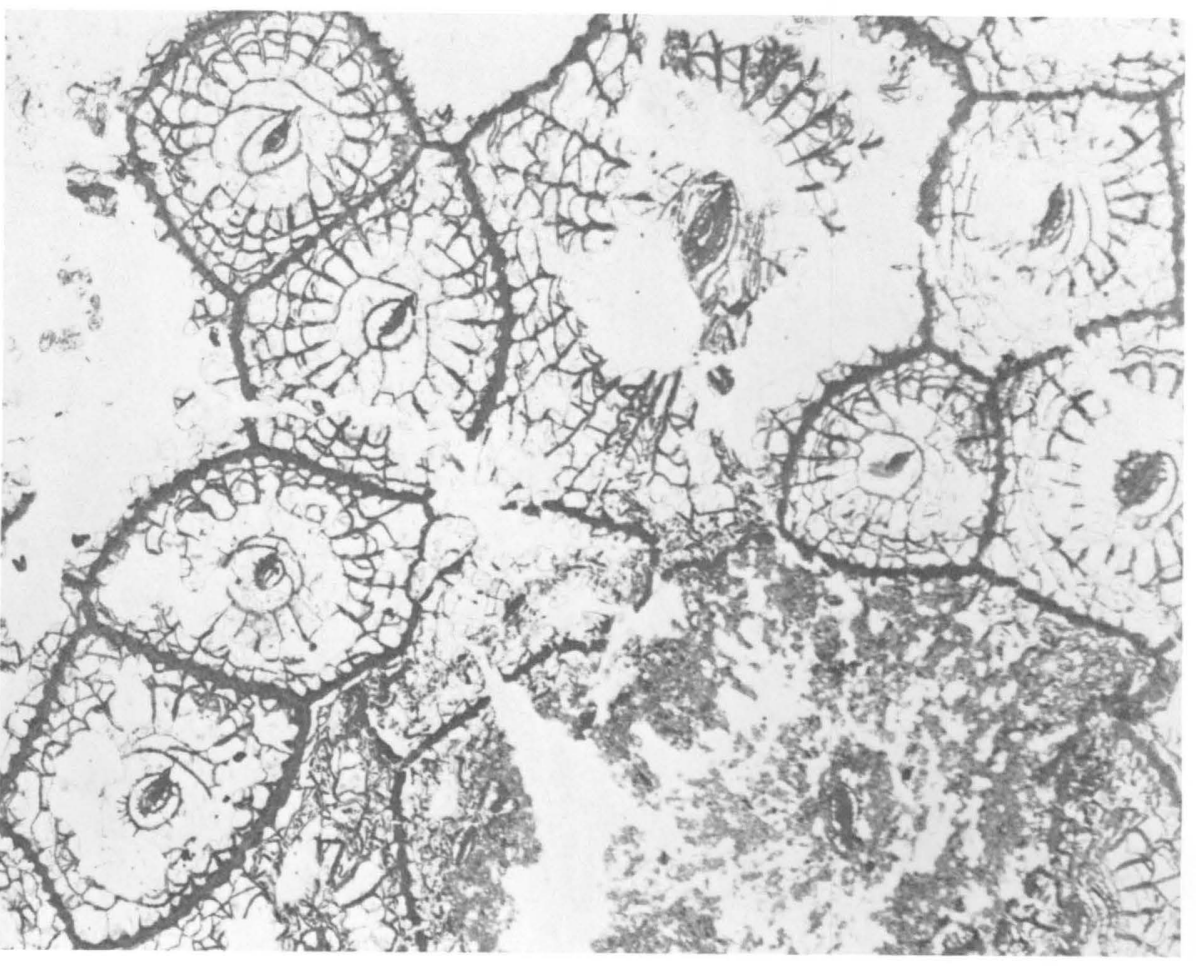

6

ACROCYATHUS FLORIFORMIS HEMISPHAERICUS (HAYASAKA) AND

ACROCYATHUS FLORIFORMIS HEMISPHAERICUS (HAYASAKA)? 


\title{
PLATE 14
}

\author{
[All figures $\times 4$ ]
}

FIGURES 1,2. Acrocyathus floriformis hemisphaericus (Hayasaka) (p. 19).

USNM 161992 (paratype of Lithostrotionella castelnaui Hayasaka). USGS Loc. 2020A-PC, Greenbrier Limestone, Virginia.

1. Transverse thin section, USNM 161992a.

2. Longitudinal thin section, USNM $161992 \mathrm{~b}$.

3, 4. Acrocyathus floriformis hemisphaericus (Hayasaka) (p. 19).

USNM 120236 (paratype of Lithostrotionella castelnaui Hayasaka). USGS Loc. 3282-PC, Hillsdale Member of Greenbrier Limestone, West Virginia.

3. Longitudinal thin section, USNM $120236 \mathrm{~b}$.

4. Transverse thin section, USNM 120236a. 


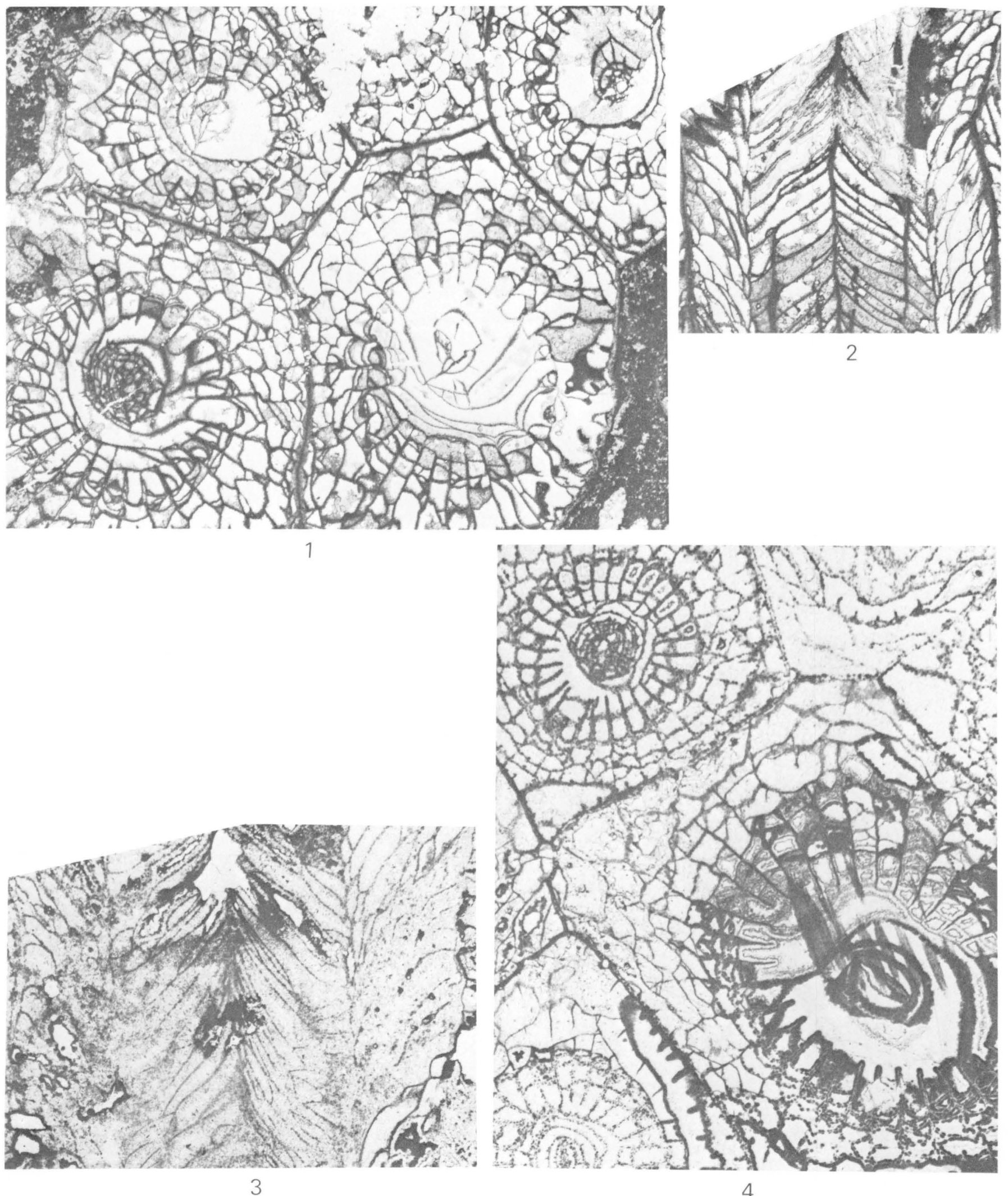


PLATE 15

FIGUREs 1-3. Acrocyathus proliferus (Hall) (p. 20).

Neotype, USNM 841. St. Louis Limestone, Illinois.

1. Transverse thin section, $\times 4$, USNM 841a.

2. Longitudinal thin section, $\times 4$, USNM $841 \mathrm{~b}$.

3 . Side view of corallum, $\times 1$. 

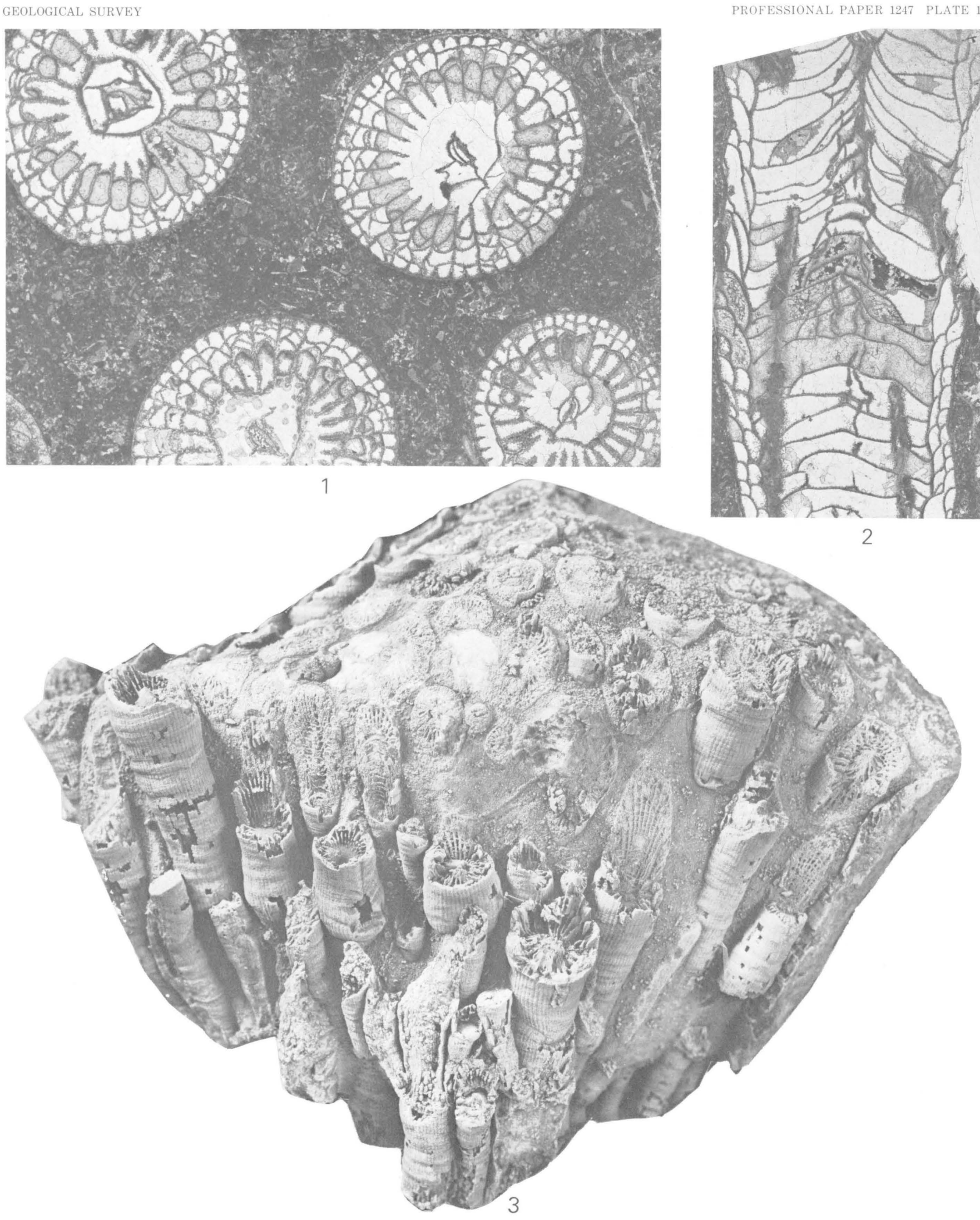

ACROCYATHUS PROLIFERUS (HALL) 


\section{PLATE 16}

FigURES 1. Acrocyathus proliferus (Hall) (p. 20).

USNM 216207. St. Louis Limestone, Tennessee.

Transverse thin section, $\times 2$, USNM 216207 a, showing crowding of corallites by profuse budding.

2. Acrocyathus floriformis floriformis d'Orbigny (p. 17).

USNM 161994. Greenbrier Limestone, Virginia.

Transverse thin section, $\times 2$, USNM 161994 a, showing cylindrical tendency of some corallites in a predominantly cerioid corallum.

3, 4. Acrocyathus proliferus (Hall) (p. 20).

USNM 216209. St. Louis Limestone, Tennessee.

3 . Longitudinal thin section, $\times 1$, USNM $216209 \mathrm{~b}$ showing cylindrical corallites in a predominantly fasciculate corallum.

4. Transverse thin section, $\times 2$, USNM 216209 a showing prismatic tendency in crowded corallites in a predominantly fasciculate corallum. 

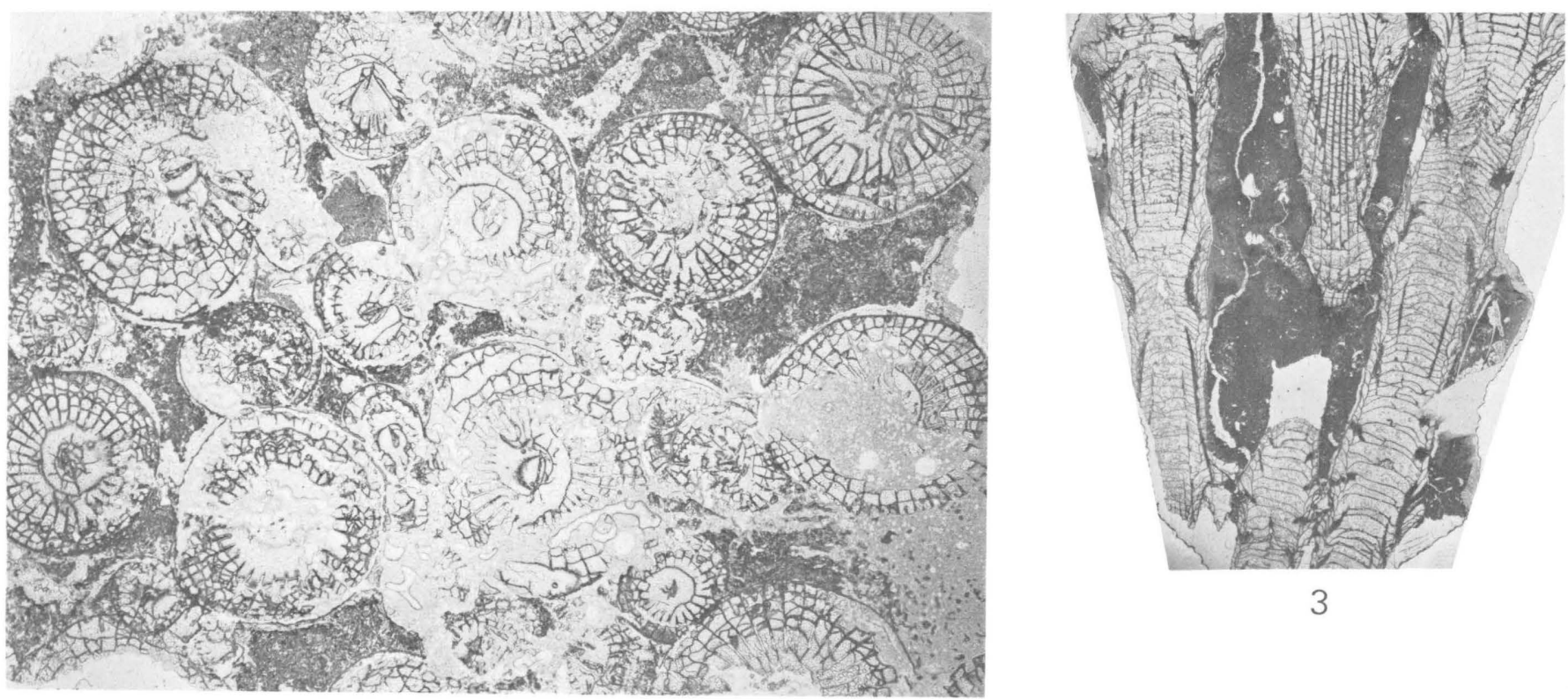

3

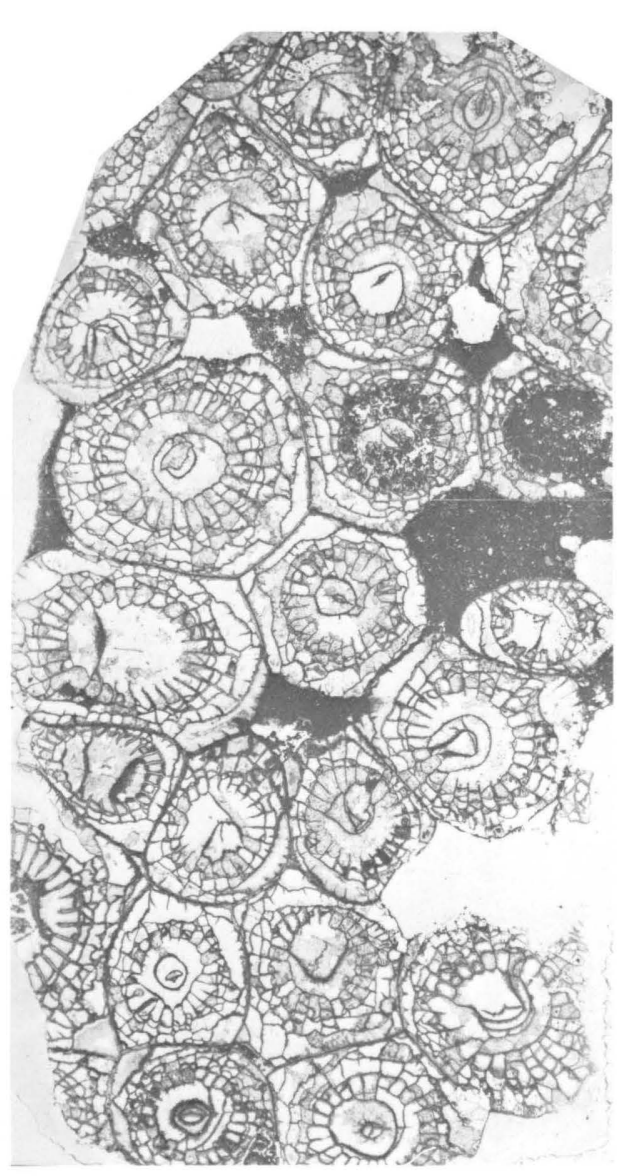

2

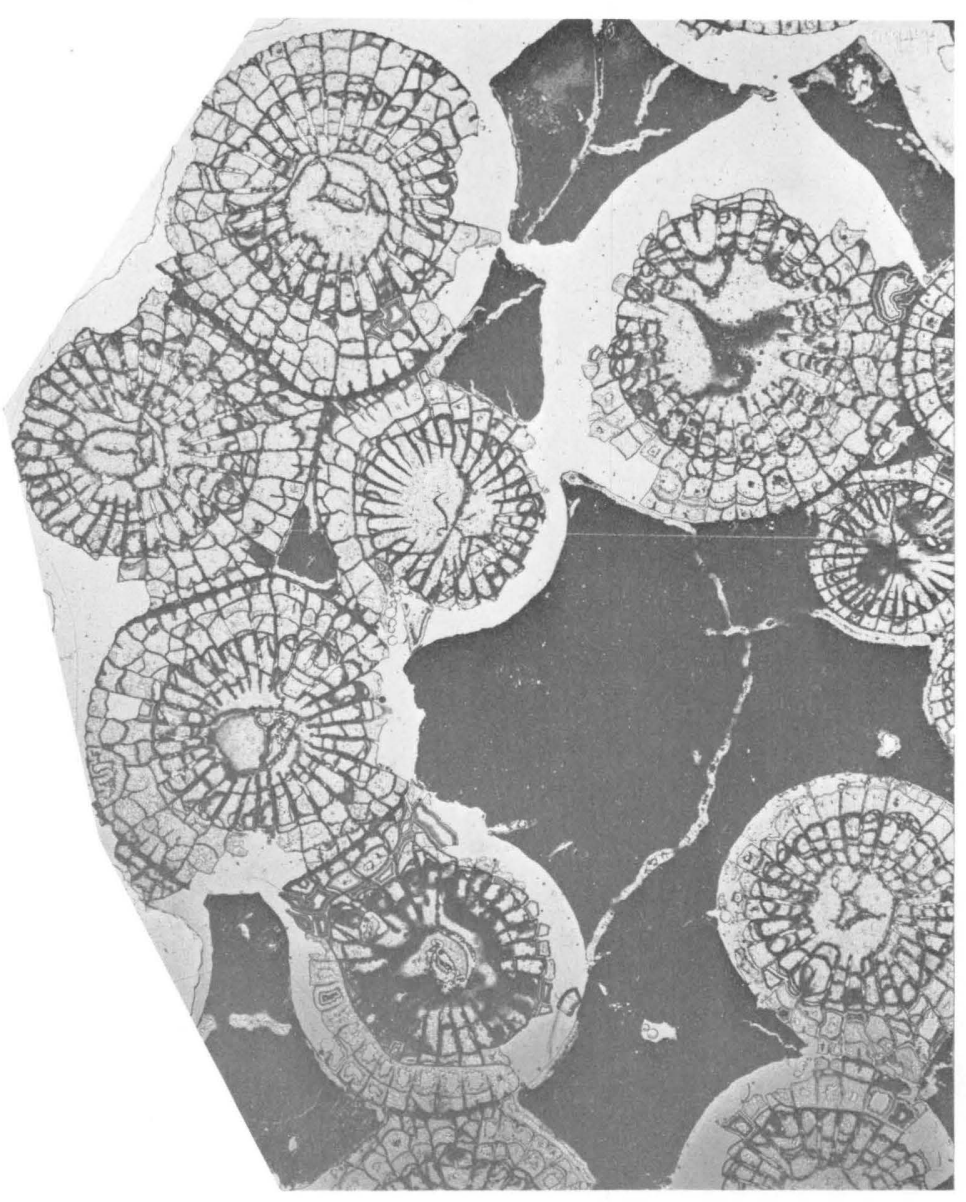

4

ACROCYATHUS PROLIFERUS (HALL) AND ACROCYATHUS FLORIFORMIS FLORIFORMIS D'ORBIGNY 


\section{PLATE 17}

[All figures $\times 4]$

Figures 1, 2. Acrocyathus pilatus n. sp. (p. 19).

Holotype, USNM 162004 (paratype of Lithostrotionella girtyi Hayasaka). USGS Loc. 499-PC, St. Louis Limestone, Illinois.

1. Transverse thin section, USNM 162004a.

2. Longitudinal thin section, USNM $162004 \mathrm{~b}$

3, 4. Acrocyathus girtyi (Hayasaka) (p. 21).

Holotype, USNM 120243. USGS Loc. 4801H-PC (green), Little Flat Formation, Utah.

3 . Longitudinal thin section, USNM $120243 \mathrm{~b}$.

4. Transverse thin section, USNM 120243a. 
GEOLOGICAL SURVEY

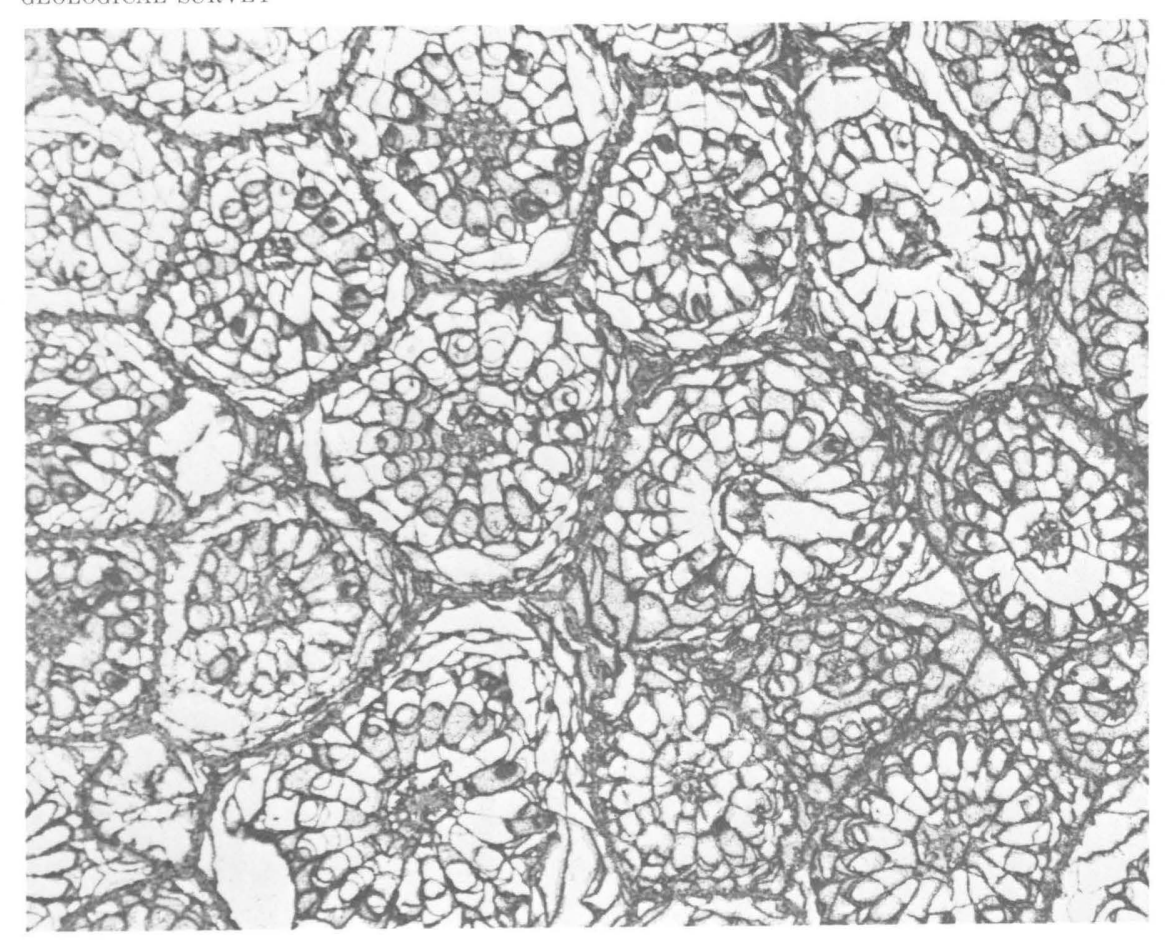

PROFESSIONAL PAPER 1247 PLATE 17

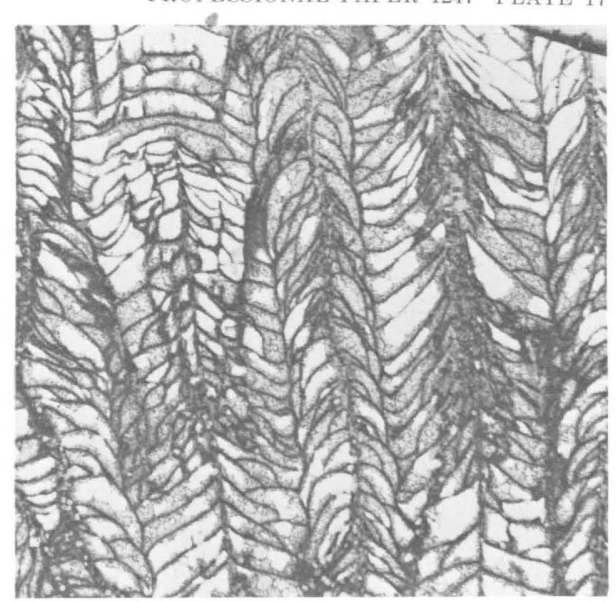

2

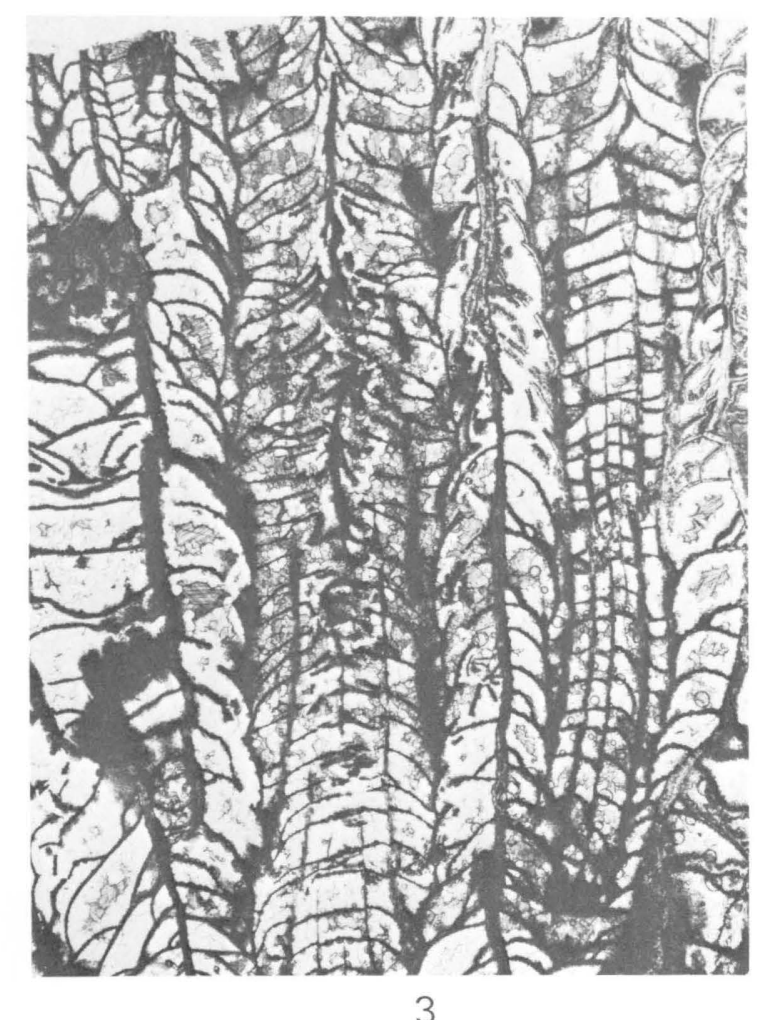

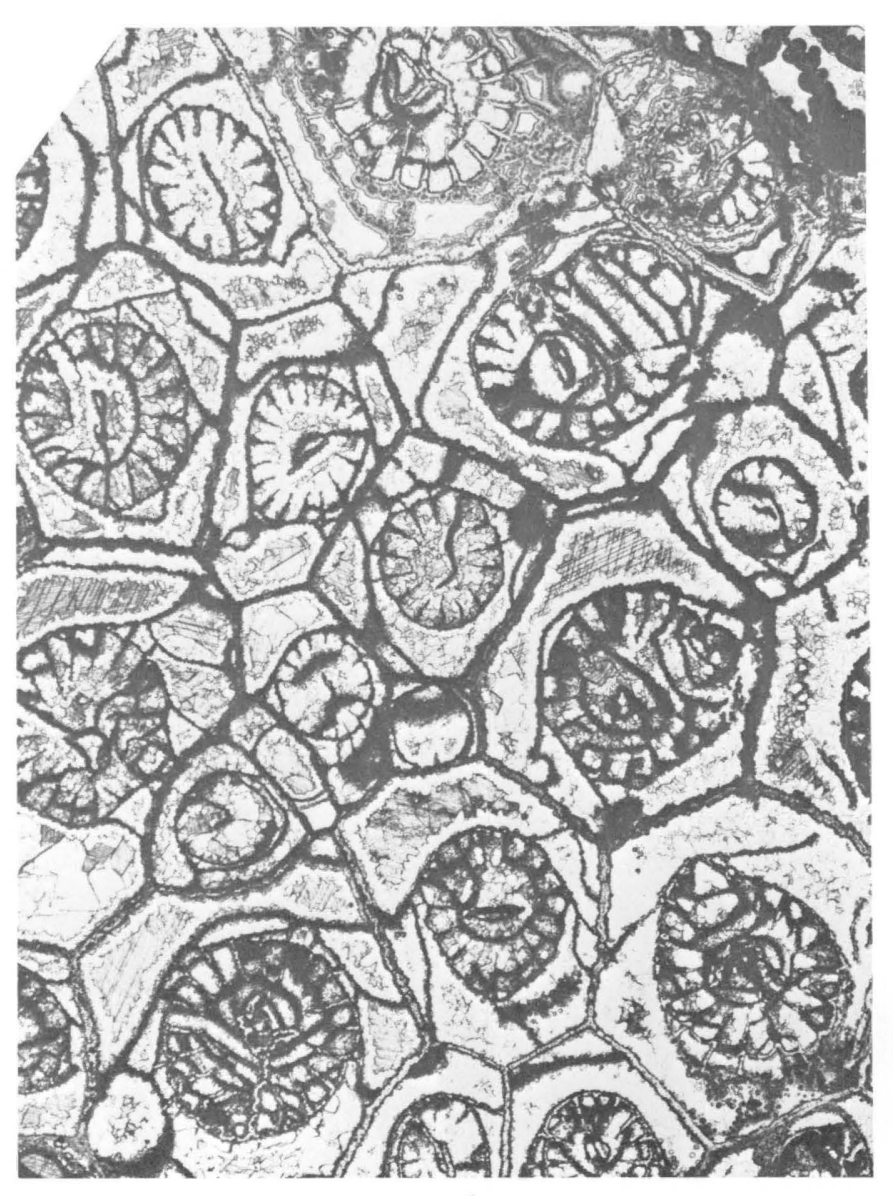

4

ACROCYATHUS PILATUS N. SP. AND ACROCYATHUS GIRTYI (HAYASAKA) 


\title{
PLATE 18
}

\author{
[All figures $\times 4$ ]
}

Figures 1-3. Petalaxis simplex (Hayasaka) (p. 26).

Holotype, USNM 120249. USGS 5893-PC, Little Flat Formation, Utah.

1. Transverse thin section, USNM 120249a.

2, 3. Longitudinal thin section, USNM $120249 \mathrm{~b}$.

4, 5. Petalaxis wyomingensis n. sp. (p. 26).

Holotype, USNM 120675 (paratype of Lithostrotionella simplex Hayasaka). USGS 7452-PC (green), "Wells" Formation), Wyoming.

4. Longitudinal thin section, USNM $120675 \mathrm{~b}$.

5. Transverse thin section, USNM $120675 \mathrm{c}$. 

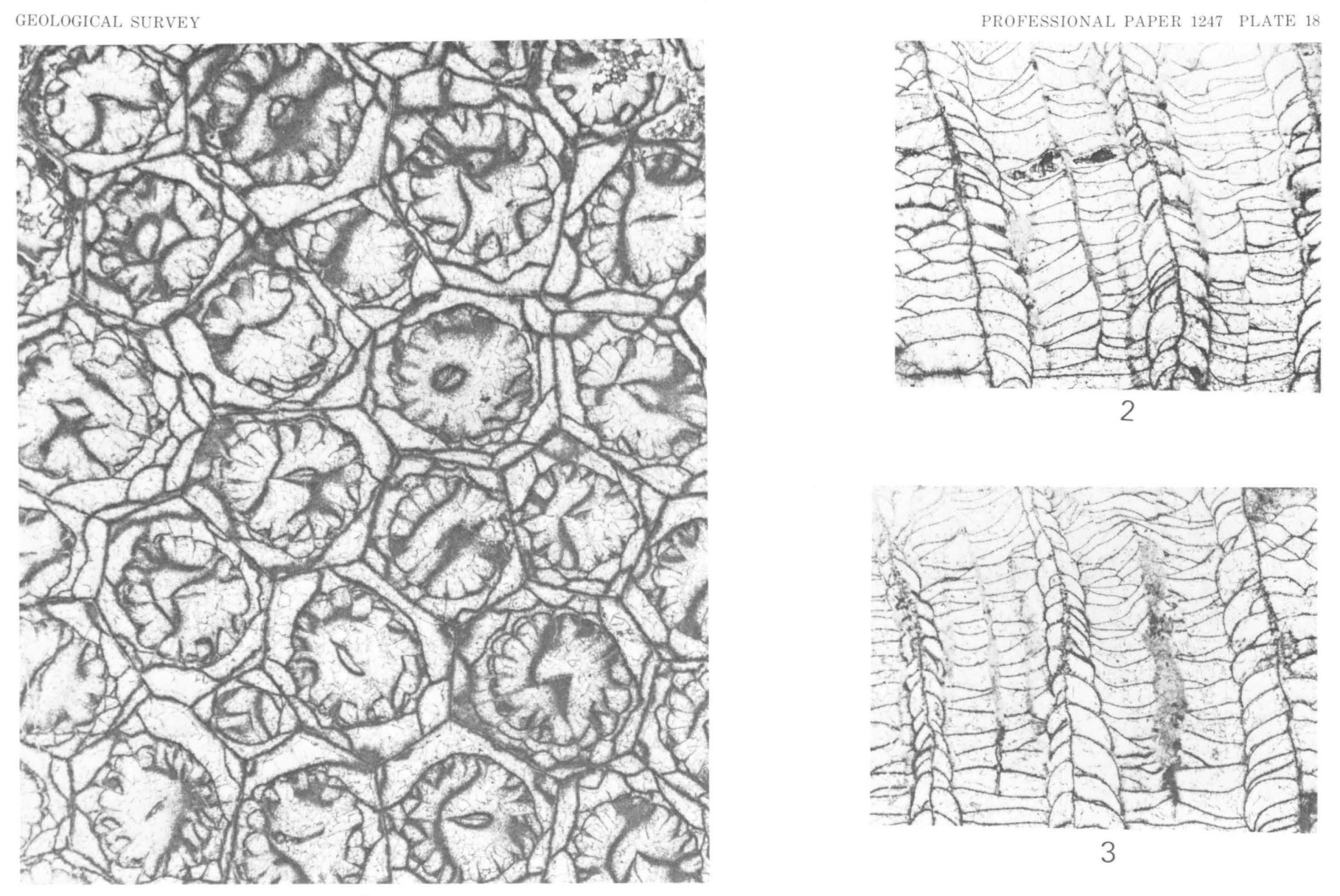

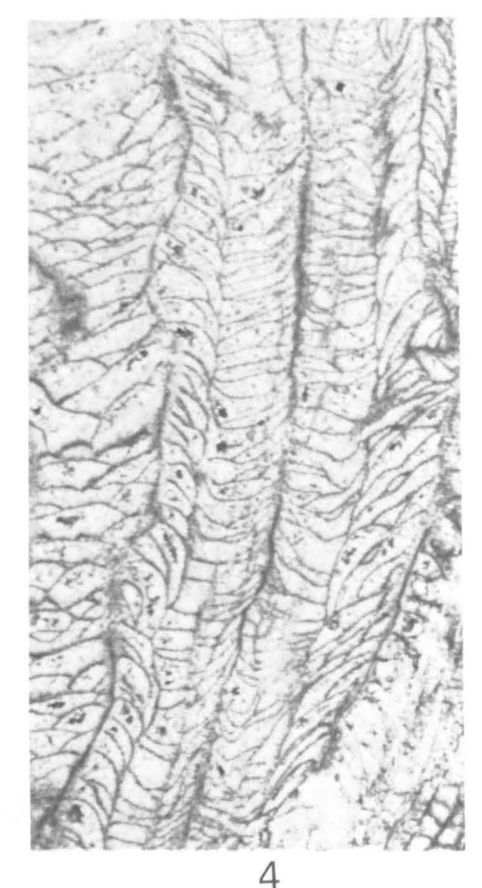

PETALAXIS SIMPLEX (HAYASAKA) AND PETALAXIS WYOMINGENSIS N. SP.

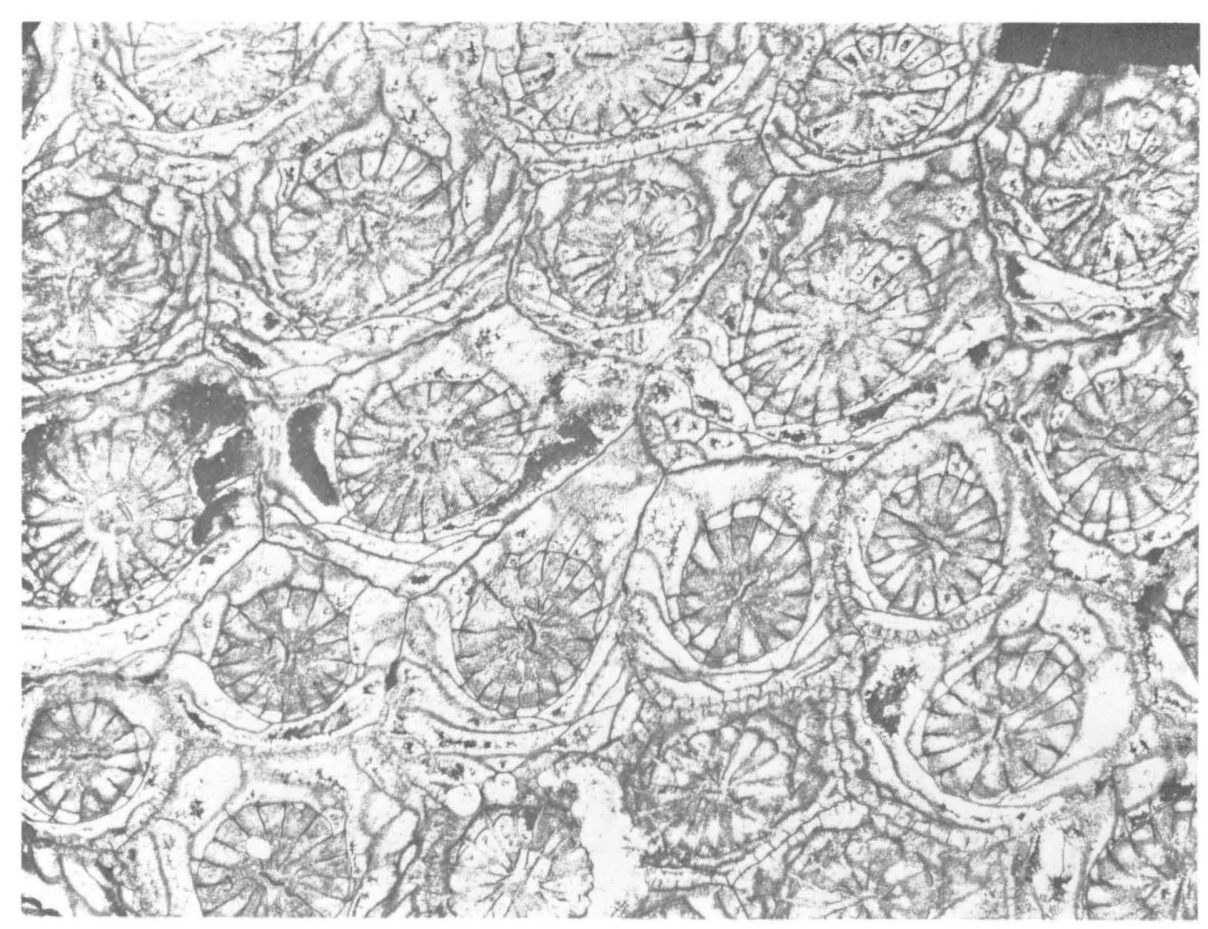

5 
PLATE 19

Figures 1-4. Petalaxis exiguus n. sp. (p. 28).

Holotype, USNM 162002B (paratype of Lithostrotionella girtyi Hayasaka). USGS Loc. 3856-PC (green), McCloud Limestone, California.

1. Transverse thin section, $\times 4$, USNM $162002 \mathrm{Ba}$.

2 , 3. Longitudinal thin section, $\times 4$, USNM $162002 \mathrm{Bb}$.

4. Oblique view of corallum, $\times 1$.

5-7. Petalaxis tabulatus (Hayasaka) (p. 26).

Holotype, USNM 120246. USGS Loc. 1476-PC, Aspen Range Formation, Idaho.

5. Longitudinal thin section, $\times 4$, USNM $120246 \mathrm{~b}$.

6. Longitudinal thin section, $\times 4$, USNM $120246 \mathrm{c}$.

7. Transverse thin section, $\times 4$, USNM 120246 a. 

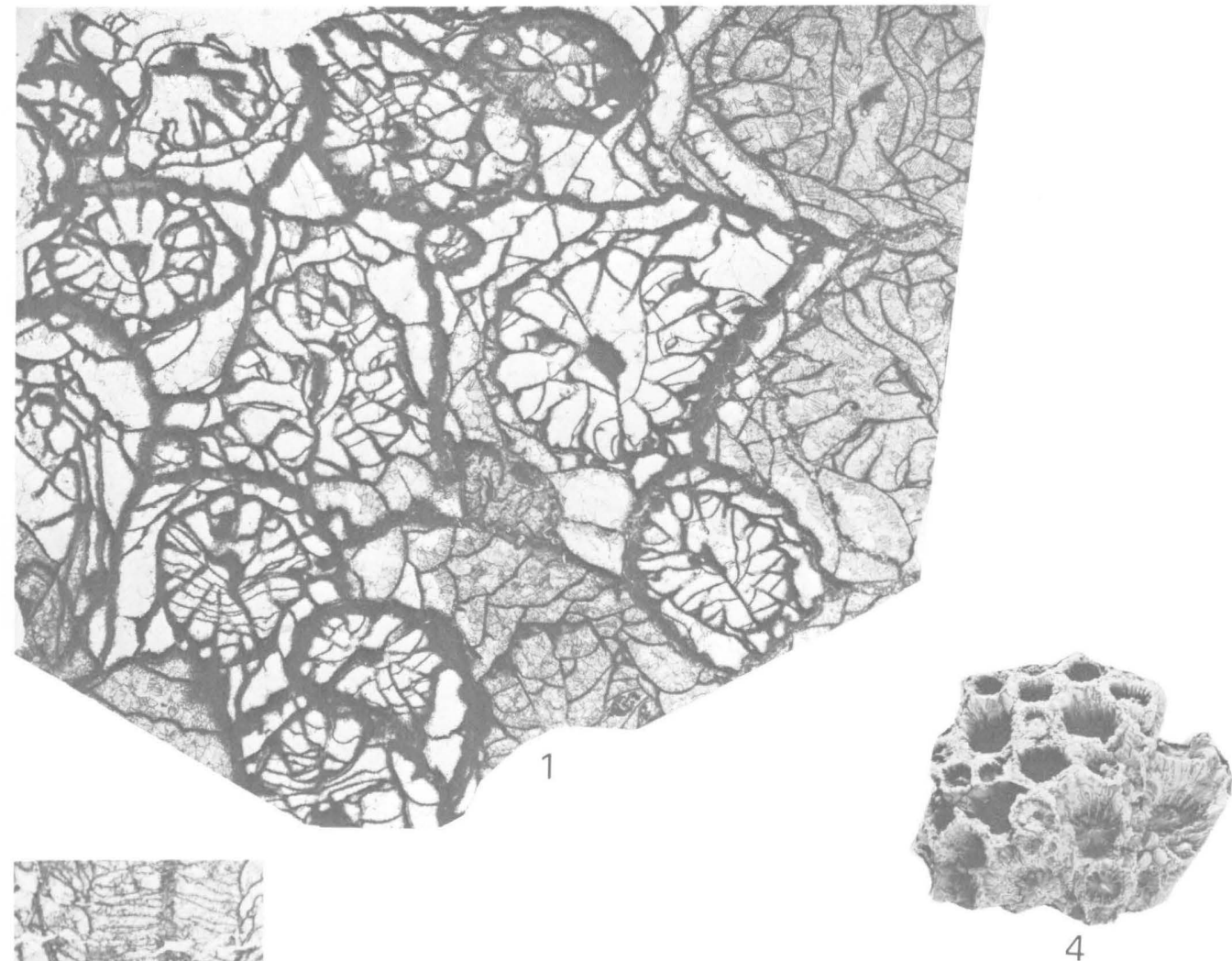

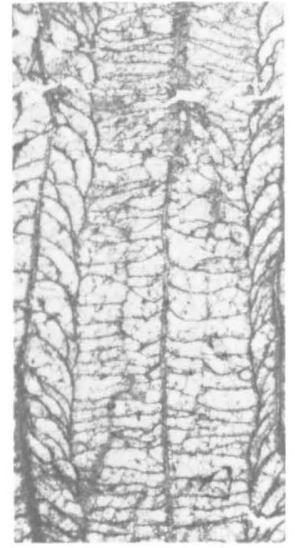

5

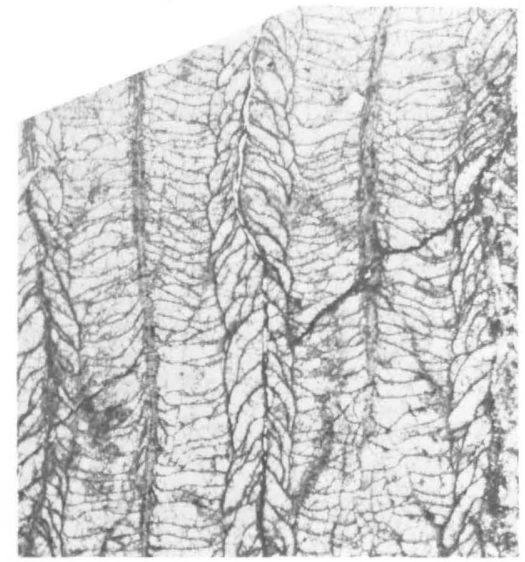

6
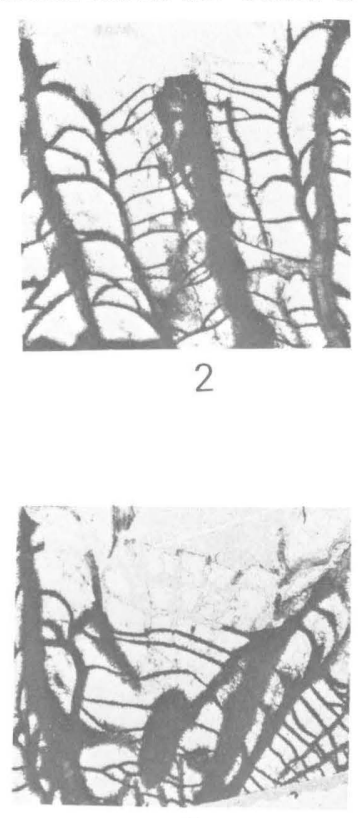

3

19.

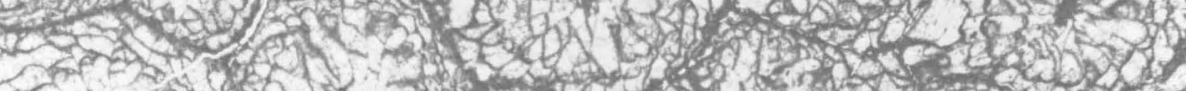

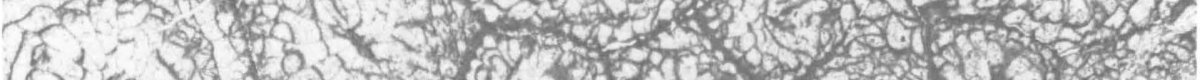

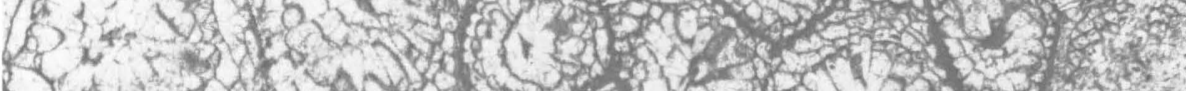

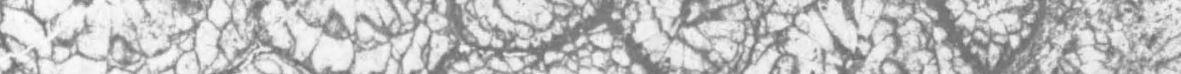

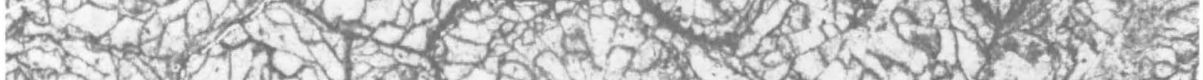

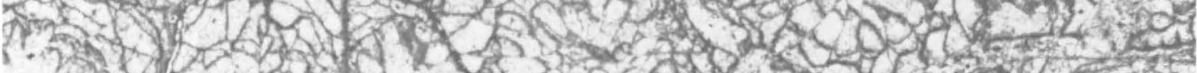

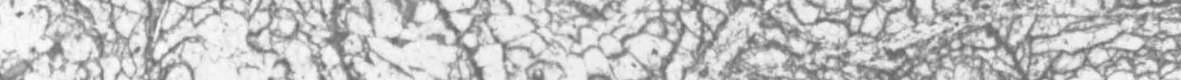

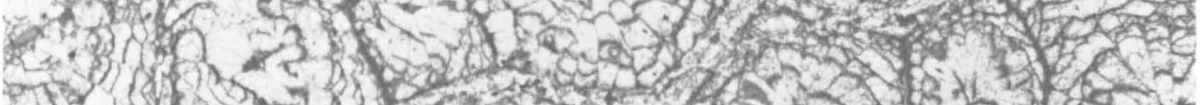

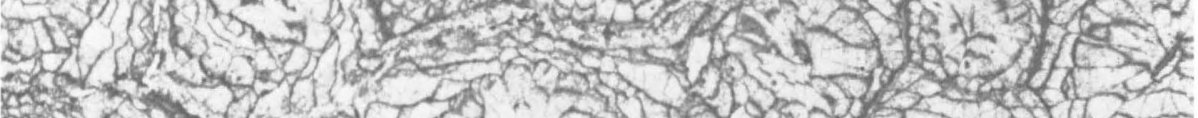

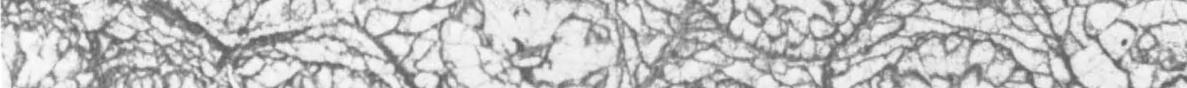

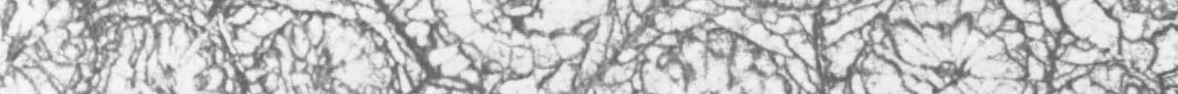

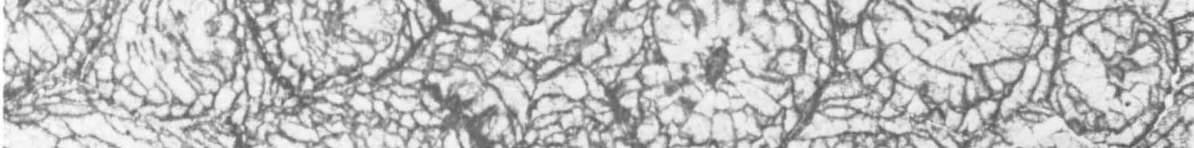
$-C^{2}$ को

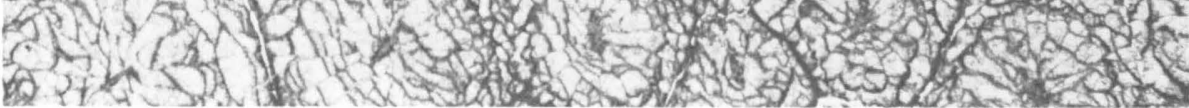
7

PETALAXIS EXIGUUS N. SP. AND PETALAXIS TABULATUS (HAYASAKA) 
PLATE 20

[All figures $\times 4$ ]

Figures 1, 2. Petalaxis occidentalis (Merriam) (p. 32).

Holotype, USNM 143440. Coyote Butte Formation, Oregon.

1. Transverse thin section, USNM 143440c.

2. Longitudinal thin section, USNM $143440 \mathrm{e}$.

3, 4. Lonsdaleia (Actinocyathus) berthiaumi (Merriam) (p. 37).

Holotype, USNM 132988. Unknown formation, Oregon.

3. Longitudinal thin section, USNM $132988 \mathrm{~d}$.

4. Transverse thin section, USNM 132988c. 

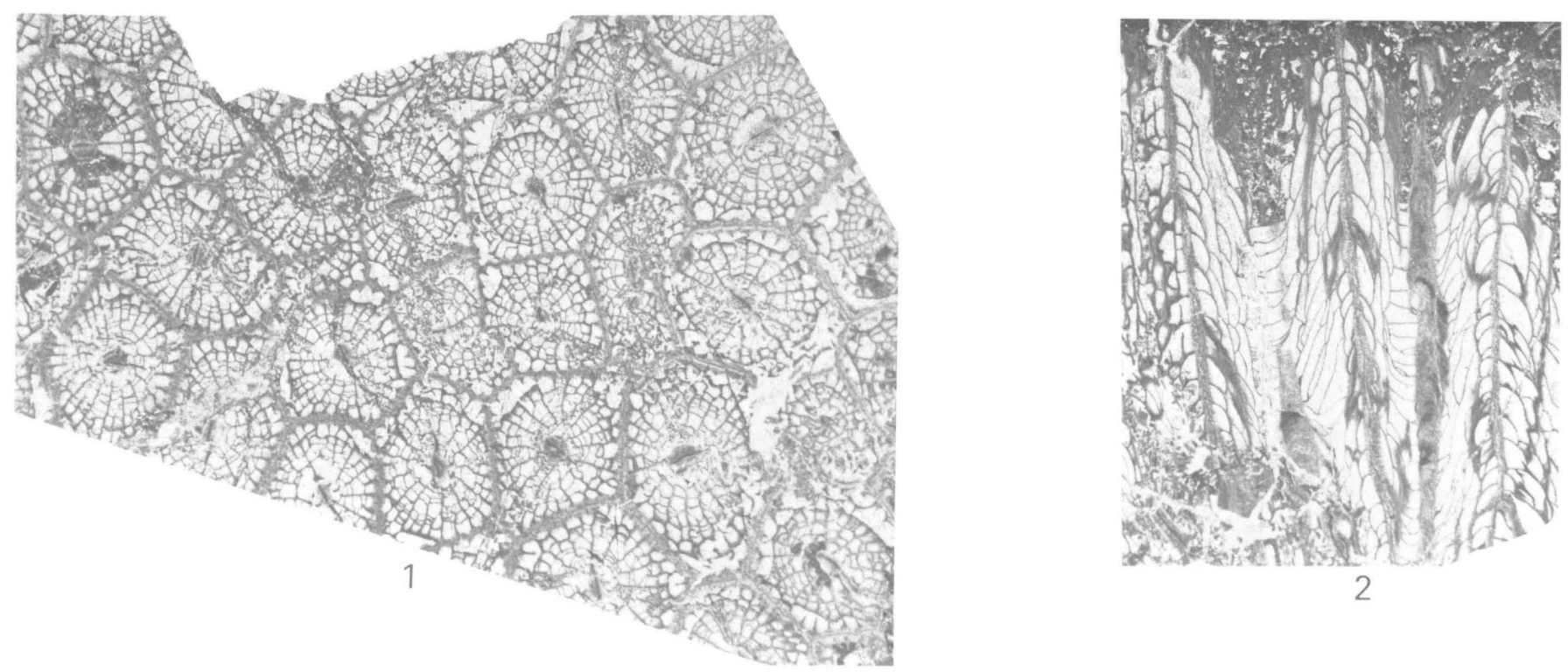

2

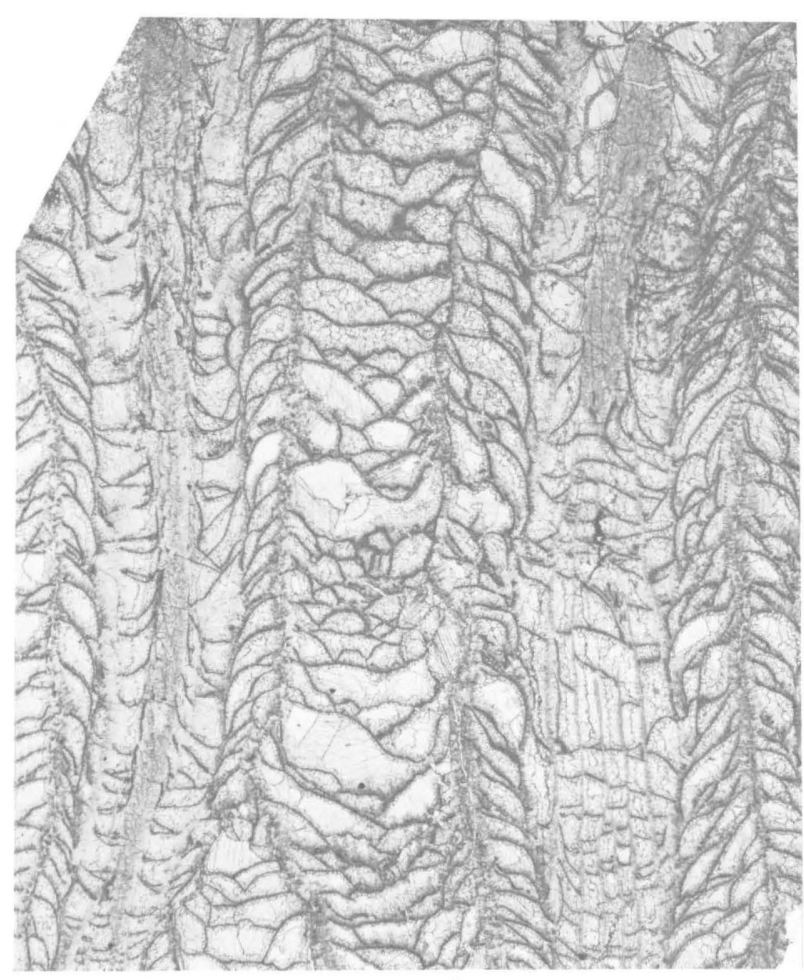

3

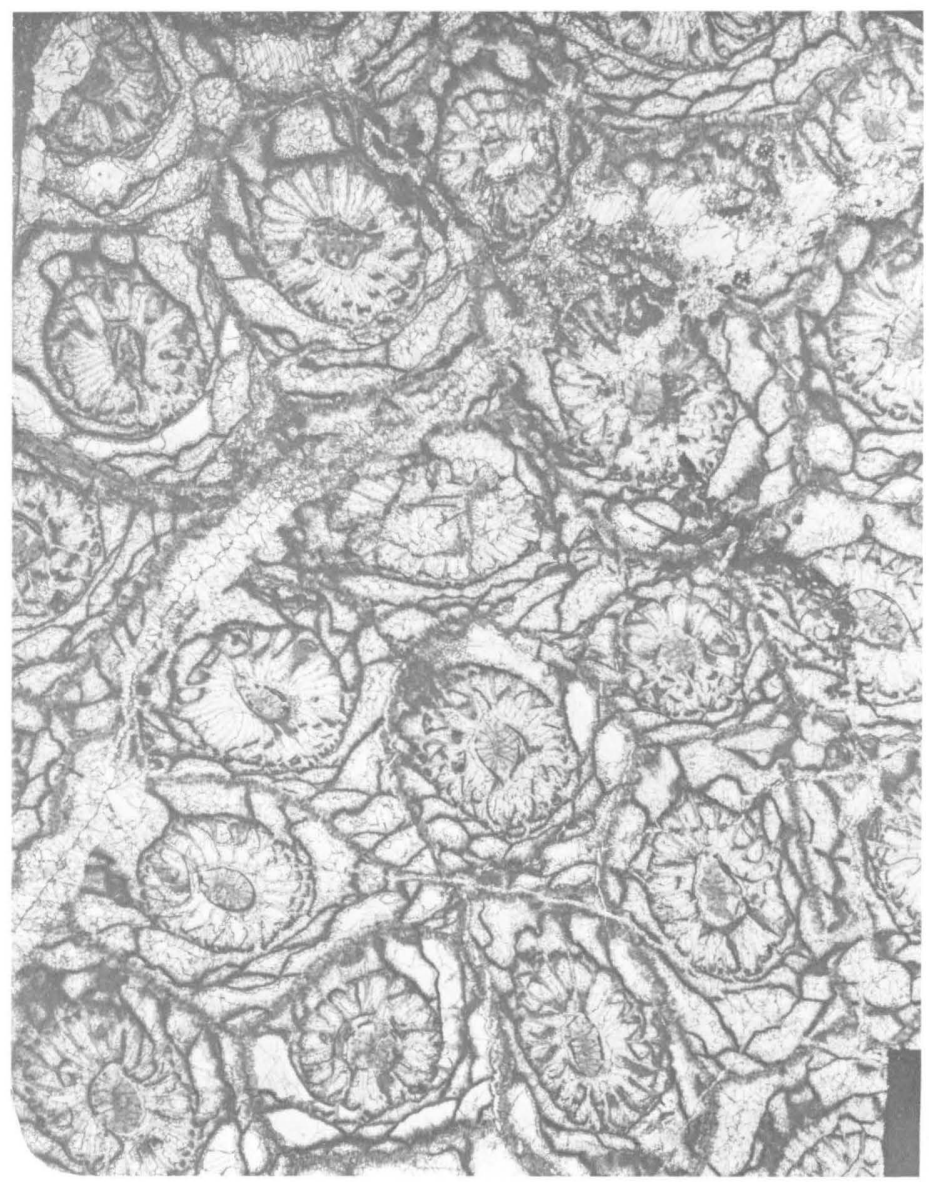

4

PETALAXIS OCCIDENTALIS (MERRIAM) AND LONSDALEIA (ACTINOCYATHUS) BERTHIAUMI (MERRIAM) 